Lucyla Tellez Merino

\title{
A EFICÁCIA DO CONCEITO DE TRABALHO DECENTE NAS RELAÇÕES TRABALHISTAS
}

Universidade de São Paulo

São Paulo

2011 


\title{
Lucyla Tellez Merino
}

\section{A EFICÁCIA DO CONCEITO DE TRABALHO DECENTE NAS RELAÇÕES TRABALHISTAS}

\author{
Tese de Doutorado apresentada perante o \\ Departamento de Direito do Trabalho e \\ Seguridade Social da Universidade de São Paulo, \\ sob a orientação do Prof. L.D. Marcus Orione \\ Gonçalves Correia.
}

Universidade de São Paulo

São Paulo 
Dedico este trabalho aos meus avós e aos meus pais. 


\section{AGRADECIMENTOS}

Ao Prof. Marcus Orione Gonçalves Correia, pela oportunidade de pesquisa e pela orientação.

Ao Prof. Ronaldo Lima dos Santos pela companhia nesta caminhada, pela confiança, pela amizade e por toda ajuda.

Ao Prof. Jorge Luiz Souto Maior, pela disposição com que sempre ofereceu ajuda na construção deste trabalho.

Ao Prof. Alysson Mascaro, pela amizade e pelo apoio.

Aos amigos da Universidade São Judas Tadeu, pela amizade e pelo apoio, em especial para Fernando, Caparroz, Adriano, Flávio, Sílvio, Wilson, Camilo, Panisa, Elaine, Jorginho, Caio, Annie, Solange, Adriana, Cacilda, Rosângela, Ivan, Regina, Monnerat, e todos os meus alunos.

A Gisele Mattar Stefanski pela amizade e pelo apoio.

Ao Renato, a Giselle, ao Ricardo e a Marli, pelo fraterno apoio. 


\section{RESUMO}

A vertente pesquisa teve por objetivo estudar o conceito de trabalho decente, na medida em que esta concepção possa atribuir maior efetividade na proteção do trabalhador, pautando não apenas as alterações legislativas, mas também a interpretação das normas de direito social e a criação e promoção de políticas públicas sobre o tema.

Pela investigação realizada, auferiu-se que o trabalho degradante é reconhecido através dos elementos que o compõe, quais sejam, alienabilidade, insegurança no trabalho, desconstrução psíquica do trabalhador, dessocialização e dessubjetivização do trabalhador, forma esta que possibilita melhor combatê-lo.

Em seguida, procurou-se estabelecer o liame entre trabalho degradante e exclusão social. Tendo em vista que a grande maioria das pessoas tem o trabalho como único modo de atingir renda para manutenção de suas vidas, a importância social do trabalho é enorme, daí porque o desemprego ou o trabalho degradante são fatores de exclusão social, ocasionando assim a marginalização do ser humano, o aumento da violência, de doenças físicas e psíquicas, entre outros males. A exclusão social através do trabalho degradante ocorre principalmente por conta de dois fenômenos, a desigualdade material e a precarização no ambiente laboral.

A Organização Internacional do Trabalho estabeleceu, por meio de Juan Somavia, então diretor geral a OIT, que trabalho decente é o "trabalho produtivo e adequadamente remunerado, exercido por homens e mulheres de todo o mundo em condições de liberdade, igualdade, segurança e dignidade, e livre de qualquer forma de discriminação", firmado em quatro pilares: a promoção dos direitos fundamentais no trabalho, o emprego, a proteção social, o fortalecimento do tripartismo e do diálogo social.

No entanto, a partir da leitura dos trabalhos publicados pela OIT, pode-se perceber que o órgão não entende o emprego, um dos pilares estruturantes do conceito, como ocorre no Brasil, Estado que o reconhece como espécie de labor fundado em diversas limitações à autonomia da vontade estabelecidas pelo ordenamento jurídico, efetivando assim proteção ao trabalhador hipossuficiente; ademais, falta ao conceito desenvolvido pela OIT a inserção clara e objetiva de que trabalho decente é um termo que jamais se compatibilizará com qualquer forma de precarização. Assim, criou-se um novo conceito, esperando que ele possibilite maior eficácia na defesa da dignidade do trabalhador, servindo de parâmetro ao 
Poder Legislativo, Judiciário e Executivo em suas ações, a saber: o trabalho decente é aquele da espécie emprego subordinado, contratado diretamente por quem se favorece dos serviços prestados, protegido concretamente pelo ordenamento jurídico imperativo que limite o exercício potestativo da autonomia da vontade do empregador, para que não seja precarizado mesmo quando formalizado, pelo qual o trabalhador aufira renda compatível com a manutenção real de sua vida e de sua família, exercendo a atividade laborativa com igualdade, segurança, liberdade, consciência e dignidade. $\mathrm{O}$ trabalho decente deve ser parâmetro para instituição ou interpretação de quaisquer políticas públicas, inclusive as econômicas, haja vista que estas se obriguem na objetivação da justiça social, motivo pelo qual deve ser respaldado na democracia participativa através da criação e fomento de espaços públicos que propiciem a participação popular independente.

Palavras-chave: direitos humanos, trabalho decente, precarização do trabalho. 


\section{SYNTHÈSE}

Cette recherche a eu comme objectif l'étude du concept de travail décent, dans la mesure où ce concept peut attribuer plus d'efficacité à la protection des travailleurs, dirigeant non seulement les modifications législatives, mais aussi l'interprétation des normes de droit social et la création et la promotion de politiques publiques sur le sujet.

Par l'investigation menée, il en ressort que le travail dégradant est reconnu à travers les éléments qui le composent, c'est à dire, l'aliénabilité, l'insécurité au travail, la déconstruction psychique du travailleur, sa désocialisation et sa désubjectivation, une forme qui permet de mieux le combattre.

Ensuite, nous avons essayé d'établir le lien entre le travail dégradant et l'exclusion sociale. Étant donné que la grande majorité des gens fait du travail son seul moyen d'atteindre un revenu pour son soutien, l'importance sociale du travail est énorme, ce qui explique pourquoi le chômage ou le travail dégradant sont des facteurs d'exclusion sociale, ce qui entraîne la marginalisation de l'être humain, l'augmentation de la violence, des maladies physiques et psychiques, entre autres. L'exclusion sociale par le travail dégradant se produit principalement en raison de deux phénomènes, l'inégalité matérielle et l'instabilité dans l'ambiance de travail.

L'Organisation Internationale du Travail a établi, grâce à Juan Somavia, à l'époque directeur général de l'OIT, que le travail décent est le «travail productif et adéquatement rémunéré, exercé par hommes et femmes du monde entier, en conditions de liberté, d'égalité, de sécurité et de dignité, et libre de toute forme de discrimination », basé sur quatre piliers: la promotion des droits fondamentaux au travail, l'emploi, la protection sociale, la fortification du tripartisme et du dialogue social.

Néanmoins, à partir de la lecture des travaux publiés par l'OIT, on s'aperçoit que l'organisation ne comprend pas l'emploi comme un des piliers structurants du concept, comme il se produit au Brésil, un état qui le reconnaît comme une espèce de travail fondé sur plusieurs limitations à l'autonomie de la volonté établies par l'ordre juridique, en accomplissant ainsi une protection insuffisante au travailleur; de plus, il manque au concept développé par l'OIT l'insertion claire et objective que le travail décent est un terme qui ne sera jamais compatible avec toute forme de précarisation. Ainsi, un nouveau concept a-t-il été créé, espérant qu'il permette plus d'efficacité pour la défense de la 
dignité du travailleur, en servant de paramètre aux Pouvoirs législatif, judiciaire et exécutif dans leurs actions, à savoir: le travail décent est celui de l'espèce d'emploi subordonné, contracté directement par qui se bénéficie des prestations, protégé concrètement par l'ordre juridique impératif qui limite l'exercice potestatif de l'autonomie de la volonté de l'employeur, pour qu'il ne soit pas précarisé, même s'il est formalisé, duquel le travailleur reçoit un revenu compatible au soutien de son niveau de vie et celui de sa famille, en exerçant l'activité du travail avec égalité, sécurité, liberté, conscience et dignité. Le travail décent doit être un paramètre pour l'institution ou l'interprétation de toutes politiques publiques, y compris les économiques, étant donné que celles-ci s'obligent à l'objectivation de la justice sociale, raison par laquelle il doit être protégé par la démocratie participative moyennant la création et l'incitation d'espaces publics qui rendent propice la participation populaire indépendante.

Mots-clés: droits de l'homme, le travail décent, insécurité de l'emploi. 


\section{RIASSUNTO}

La presente ricerca ha avuto come obiettivo studiare il concetto di lavoro decente, nella misura in cui questa concezione possa attribuire maggiore effettività nella protezione del lavoratore, facendo riferimento non soltanto alle alterazioni legislative ma anche all'interpretazione delle norme di diritto sociale e alla creazione e promozione di politiche pubbliche sul tema.

Secondo la ricerca effettuata, è stato rilevato che il lavoro degradante viene riconosciuto per mezzo degli elementi che lo compongono, quali alienabilità, mancanza di sicurezza nel lavoro, decostruzione psichica del lavoratore, insocievolezza e desoggettivazione del lavoratore, ciò che permette di combatterlo meglio.

In seguito, si è cercato di stabilire il legame tra lavoro degradante ed esclusione sociale. Considerando che la grande maggioranza delle persone ha il lavoro come unico modo di avere un reddito per il mantenimento delle loro vite, l'importanza sociale del lavoro è immensa, ecco perché la disoccupazione o il lavoro degradante sono fattori di esclusione sociale e sono causa dunque di emarginazione dell'essere umano, di crescita della violenza, di malattie fisiche e psichiche, tra altri mali. L'esclusione sociale per via del lavoro degradante avviene soprattutto a causa di due fenomeni, la disuguaglianza materiale e la precarizzazione dell'ambiente lavorativo.

L'Organizzazione Internazionale del Lavoro ha stabilito, attraverso Juan Somavia, allora Direttore Generale della OIT, che lavoro decente è quel "lavoro produttivo e adeguatamente remunerato, eseguito da uomini e donne di tutto il mondo in condizioni di libertà, uguaglianza, sicurezza e dignità, e libero da qualunque forma di discriminazione", basato su quattro pilastri: la promozione dei diritti fondamentali nel lavoro, l'impiego, la protezione sociale, il rafforzamento del tripartismo e del dialogo sociale.

Tuttavia, dalla lettura dei lavori pubblicati dalla OIL si può percepire che questo organo non intende l'impiego, uno dei pilastri della struttura del concetto, nello stesso modo come viene inteso in Brasile, Stato che lo riconosce come tipo di lavoro fondato su diverse limitazioni relative all'autonomia della volontà, stabilite dall'ordinamento giuridico, effettivando così protezione al lavoratore iposufficiente; inoltre manca al concetto sviluppato dalla OIL l'inserimento chiaro e obiettivo che il lavoro decente è un termine che non sarà mai compatibile con qualunque forma di precarizzazione. Così si è creato un nuovo concetto, in attesa che renda possibile una maggiore efficacia nella difesa della dignità del lavoratore, che servirà come parametro ai Poteri Legislativo, Giudiziario ed 
Esecutivo nelle loro azioni, ossia: il lavoro decente è quello di tipo subordinato, assunto direttamente da colui che viene favorito dai servizi prestati, protetto concretamente dall'ordinamento giuridico imperativo che limiti l'esercizio potestativo dell'autonomia della volontà del dattore di lavoro, affinché non sia precarizzato anche se sarà formalizzato, attraverso il quale il lavoratore possa incassare un reddito adeguato al mantenimento reale della sua vita e della sua famiglia nell'esercizio dell'attività lavorativa con uguaglianza, sicurezza, libertà, consapevolezza e dignità. Il lavoro decente deve essere parametro per l'istituzione o l'interpretazione di qualunque politica pubblica, comprese quelle economiche, considerando che queste si responsabilizzino dell'oggettivazione della giustizia sociale, motivo per cui deve avere l'appoggio della democrazia partecipativa attraverso la creazione e l'incremento di spazi pubblici che promuovano la partecipazione popolare indipendente.

Parole chiave: diritti umani, lavoro dignitoso, la precarietà del lavoro. 
LISTA DE ABREVIATURAS E SIGLAS

SIGLA

ABREA

ADCT

$\mathrm{CF} / 88$

CLT

$\mathrm{CNJ}$

CTPS

DIEESE

EPI

FEBRABAN

IPEA

LOAS

MPT

MTE

NR

OEI

OIT

ONU

PED

PIA

PNUD

SAA

SINTHORESP

TAC

UNIFESP

\section{SIGNIFICADO}

Associação Brasileira dos Expostos ao

Amianto

Ato das Disposições Constitucionais

Transitórias

Constituição Federal Brasileira de 1988

Consolidação das Leis do Trabalho

Conselho Nacional de Justiça

Carteira de Trabalho e Previdência Social

Departamento Intersindical de Estatística e

Estudos Socioeconômicos

Equipamento de Proteção Individual

Federação Brasileira de Bancos

Instituto de Pesquisa Econômica Aplicada

Lei orgânica da assistência social

Ministério Público do Trabalho

Ministério do Trabalho e Emprego

Norma Regulamentadora

Organização Dos Estados Ibero-Americanos para a Educação, a Ciência e a Cultura

Organização Internacional do Trabalho

Organização das Nações Unidas

Pesquisa de Emprego e Desemprego

População em Idade Ativa

Programa das Nações Unidas pelo

Desenvolvimento

Síndrome de Abstinência de Álcool

Sindicato dos hotéis, restaurantes, bares e

similares de São Paulo

Termo de Ajuste de Conduta

Universidade Federal de São Paulo 


\section{SUMÁRIO}

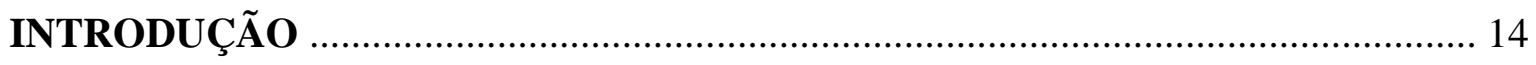

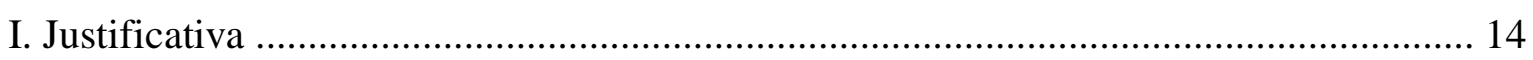

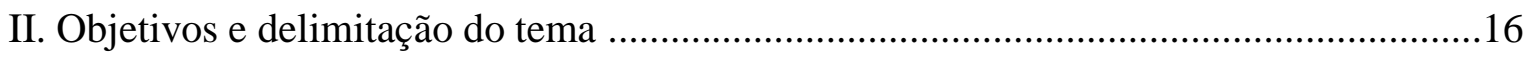

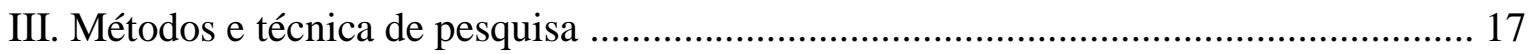

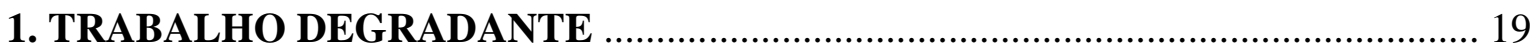

1.1 Trabalho degradante e a concepção marxista de trabalho .......................................... 19

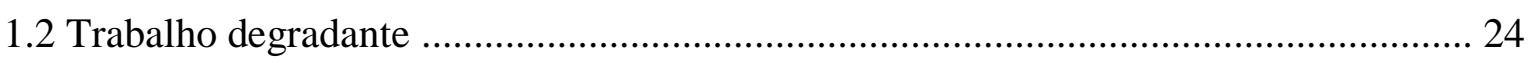

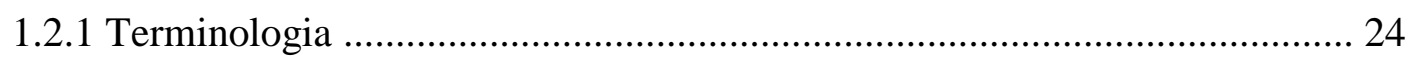

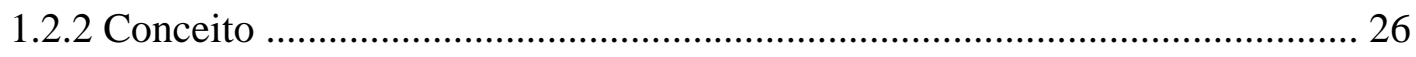

1.2.3. Elementos essenciais do trabalho degradante ........................................... 29

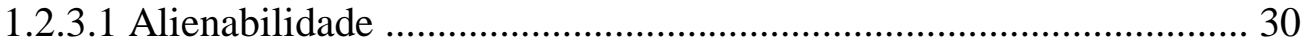

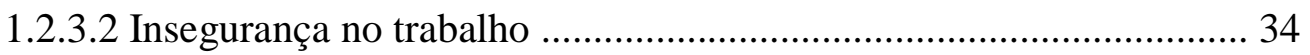

1.2.3.3 Desconstrução psíquica do trabalhador ........................................... 49

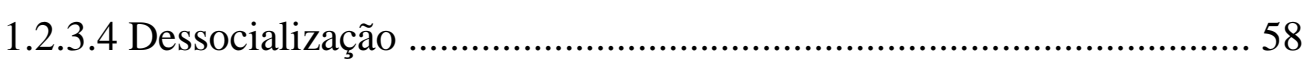

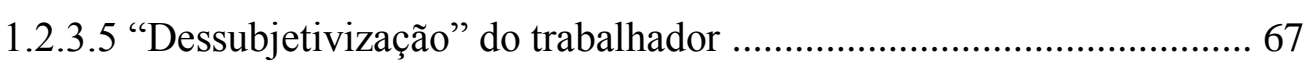

2. O TRABALHO DEGRADANTE COMO FATOR DE EXCLUSÃO SOCIAL .... 72

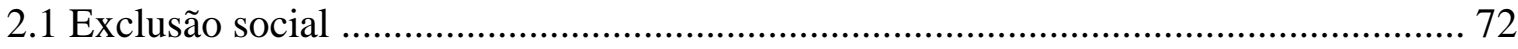

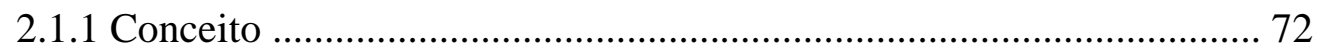

2.1.2 Formas …............................................................................. 77

$2.2 \mathrm{O}$ trabalho degradante como fator de exclusão social .............................................. 83

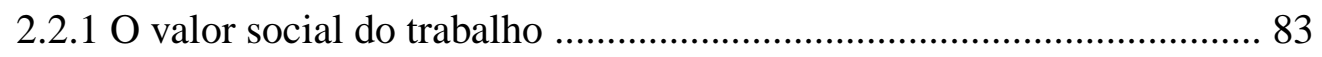

2.2.2 A exclusão social pelo trabalho degradante ...................................... 95

2.2.3 Impactos sociais do trabalho degradante ........................................... 107

\section{TRABALHO DECENTE À LUZ DA ORGANIZAÇÃO INTERNACIONAL DO}

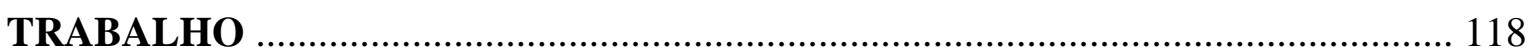

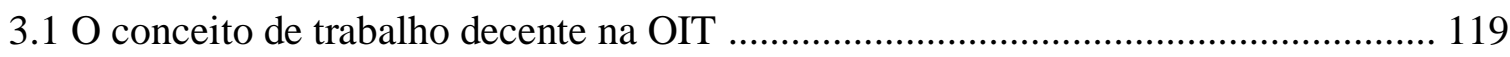

3.2 Os quatros pilares do conceito de trabalho decente segundo a OIT ........................ 127

3.2.1 A promoção dos direitos fundamentais no trabalho ........................ 127

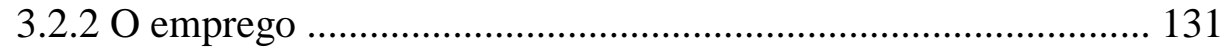


3.2.3 Proteção social .............................................................................. 132

3.2.4 Fortalecimento do tripartismo e do diálogo social ............................ 139

$3.3 \mathrm{O}$ trabalho decente na doutrina nacional e internacional .......................................... 143

4. A RECONSTRUÇÃO DO CONCEITO DO TRABALHO DECENTE E SUA

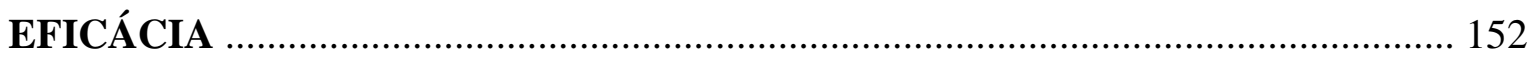

4.1 Análise crítica do conceito de trabalho decente da OIT ………………………...... 152

4.1.1 Igualdade das partes no contrato de trabalho .................................. 152

4.1.2 Minimização de direitos ............................................................. 159

4.1.3 Espaços Públicos e ampliação da democracia participativa ............... 173

4.1.4. A eficácia do trabalho decente por meio da aplicação dos princípios basilares do Direito do Trabalho .............................................................. 182

$4.2 \mathrm{O}$ conceito de trabalho decente ........................................................................... 200

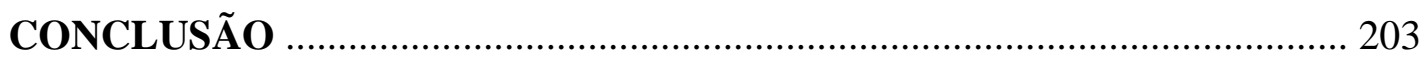

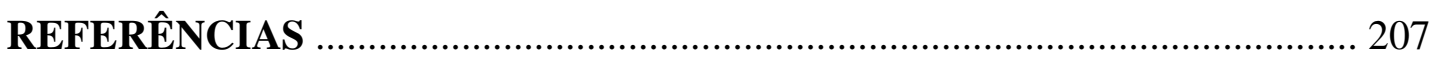




\section{INTRODUÇÃO}

\section{Justificativa}

O termo trabalho decente representa a idéia da ação realizada pelo homem, no ambiente laboral, que, juntamente com outros direitos como saúde e segurança, torna sua vivência digna. No entanto, a aludida expressão, pela quanto abarca e por todas suas possibilidades e efeitos, é de difícil conceituação.

A Organização Internacional do Trabalho (OIT) conceitua trabalho decente como $o$ trabalho produtivo e adequadamente remunerado, exercido em condições de liberdade, igualdade, segurança e dignidade, e livre de qualquer forma de discriminação, calcando tal definição em quatro objetivos estratégicos, a saber: 1) a promoção dos direitos fundamentais no trabalho; 2) o emprego; 3) proteção social e 4) fortalecimento do tripartismo e do diálogo social.

A primeira constatação que se pode suscitar na vertente pesquisa é que a realidade pode se deparar com situações de trabalho que de fato são degradantes, ainda que sugestionem uma contemplação do conceito de trabalho decente da OIT, como, por exemplo, a terceirização de trabalho nas chamadas atividades-meio, fenômeno reconhecido no Brasil como lícito, mas que de fato não atende à dignificação do trabalhador.

Assim, a proposta desta pesquisa parte do estudo do trabalho degradante, identificando seu significado e seus elementos caracterizadores, sendo certo que esse esclarecimento auxiliará na criação do novo conceito de trabalho decente, na medida em que propicia o estabelecimento de parâmetros entre esses dois fenômenos que se contrastam.

Ainda na persecução desse intuito, a pesquisa prossegue esclarecendo como o trabalho degradante é fator de exclusão social, mormente porque, ainda que a sociedade esteja em um momento de transição da modernidade para a contemporaneidade (ou pósmodernidade), o trabalho ainda é um elemento social grandemente valorizado, e este estudo se mostra relevante quando constata, por meio de casuísticas paradigmáticas, estatísticas e outras fontes, que, quanto mais protegido juridicamente o trabalhador, mais incluído socialmente ele está, e, ao contrário, quanto menos juridicamente protegido, mas excluído socialmente se encontra. 
Nesse compasso, o emprego, na caracterização jurídica do termo, tem se mostrado, de todas as formas possíveis de trabalho, a que mais contempla o trabalho decente, especialmente amparando este fenômeno nos princípios que estruturam o Direito do Trabalho e lhe dão autonomia como ramo do Direito.

Como já pontuado, a determinação do que é trabalho degradante e de como ele se transforma em fator de exclusão social auxilia na construção de um novo conceito de trabalho decente, pois traceja limites entre os dois pólos, demarcando, assim, a ocorrência de um ou de outro fenômeno.

Cabe ainda, no caminho indicado de construção de um novo conceito de trabalho decente, demonstrar como a OIT, organismo de referência no universo das relações laborais, conceitua e estrutura o tema, através de objetivos delimitadores do conceito, observando não apenas a regulamentação emitida pelo Órgão, mas também os estudos e doutrinas por ele promovidas.

Como se pôde constatar, por vezes tais estudos extrapolam os parâmetros indicados pela OIT e acabam servindo como base de justificativa para um desvirtuamento do significado de trabalho decente originalmente oferecido pelo Organismo. Pode-se perceber a gravidade dessa constatação quando do levantamento doutrinário nacional e internacional sobre o tema, pois todos os trabalhos analisados tinham por base o conceito e objetivos oferecidos pela OIT, o que poderia gerar um efeito propagador desse desvirtuamento apontado.

Os debates oferecidos são primordiais, na medida em que sem eles não se poderia oferecer uma análise crítica do conceito de trabalho decente hoje difundido e dos pilares em que se estrutura, sendo, assim, ponto de partida da criação do novo conceito. Afinal, a partir da constatação dos seus pontos frágeis é que se inicia a formulação, quer-se crer, mais efetiva dessa definição.

Para tanto, a crítica se inicia com a discussão sobre a paridade das partes da relação de trabalho no contrato de emprego, determinando se existe ou não, neste contexto, autonomia da vontade do trabalhador, e, assim sendo, se esse instrumento que formaliza a relação de emprego deve ser valorizado como um simples contrato, como contrato de adesão ou mesmo se este instrumento pode ser denominado de contrato, para então poder determinar os verdadeiros efeitos jurídicos que dele advêm.

Será também questionada a idéia, amplamente divulgada na doutrina humanista, de que a garantia de um rol "mínimo de direitos" poderia assegurar a dignidade do trabalhador, tendo em vista que essa concepção pode levar a graves equívocos, como a 
atribuição de direitos distintos a trabalhadores de diferentes regiões, sem que objetivamente esse fato traga impactos que a justifique. Ademais, quer parecer que, alcançado este rol mínimo, nada mais será preciso fazer na melhoria da condição do trabalhador, ainda que exista de fato essa possibilidade.

A ausência da figura do trabalhador como partícipe da organização da empresa, ou seja, o trabalhador participando democraticamente daquilo que the afeta dentro da organização da empresa, podendo opinar e auxiliar na tomada de decisões que atingem a mão-de-obra, também é questão determinante dentro do debate oferecido e será devidamente ventilada no trabalho.

A partir da crítica formulada e dos pontos frágeis ou faltantes da OIT, será indicado e debatido cada ponto fundamental do conceito, para então, se apresentar o novo conceito de trabalho decente.

Esse novo conceito não teria valor, se não servisse ao propósito de efetivar o trabalho decente, não só na inserção de direitos no ordenamento jurídico, mas como parâmetro de interpretação do Direito do Trabalho e do Processo do Trabalho, como princípio informativo no exercício do Poder Legislativo e das fontes autônomas (como a Convenção Coletiva de Trabalho), e também princípio informativo na formulação de Políticas Públicas.

Portanto, o último capítulo da vertente tese procurará demonstrar a concretização do trabalho decente na jurisprudência, no ordenamento jurídico e nas políticas de fomento de trabalho, sugerindo formas mais avançadas de efetivação desse direito a partir do novo conceito apresentado.

\section{Objetivos e delimitação do tema}

O vertente trabalho tem por objetivo maior a apresentação de um novo conceito de trabalho decente, a partir da definição mundialmente disseminada pela OIT e da interpretação que o Órgão vem atribuindo ao termo, a fim que esse significado possa se traduzir em efetivação da dignidade na realidade concreta dos trabalhadores, aproximandoos, assim, do contexto material, concreto, de dignificação do homem no ambiente laboral.

Nessa toada, em um crescente lógico de conhecimento, são objetivos derivados da pesquisa, primeiramente, determinar o que é e quais são os elementos que moldam o 
trabalho degradante, marcando, assim se espera, os contornos do que degrada e do que dignifica o trabalhador na relação de trabalho. Outro objetivo é a demonstração da relação estreita entre exclusão social e trabalho degradante e, ao contrário, inclusão social e trabalho decente.

Vale ressaltar que, embora pontualmente e por conveniência do desenvolvimento do tema possa se expandir, basicamente a pesquisa se limitará ao estudo do trabalho decente especificamente nas relações de emprego que, por contar com mais proteção legalmente instituída, e por ter parâmetros delimitadores extremamente úteis na busca da dignidade do trabalhador nos princípios estruturais do Direito do Trabalho, é a forma de labor que mais instrumentaliza essa idéia.

\section{Métodos e técnica de pesquisa}

A complexidade dos temas tratados não permite a pretensão de imaginar que apenas um único método científico possibilite a formação de um caminho linear que responda aos questionamentos suscitados. Atualmente, a teoria científica que mais se compatibiliza com o estudo das ciências humanas é o construtivismo, tendo em vista que combina dois procedimentos, como ensina Marilena Chauí (2005, p. 221): um racionalista, que exige que o método lhe permita e lhe garanta estabelecer axiomas, postulados, definições e deduções sobre o objeto científico, e o outro empirista, que exige que a experimentação guie e modifique os axiomas, postulados, definições e demonstrações. A eles, complementa a aludida autora, acrescenta-se a idéia de conhecimento aproximativo e corrigível, buscando assim uma explicação da realidade.

Assim, o que se pretende é o emprego de mais de uma forma de raciocínio metodológico capaz de dar conta da construção aqui realizada, ampliando a gama de análises e de sugestões para o deslinde das questões apresentadas.

Quando necessário, será utilizada uma cadeia de raciocínio dedutivo em ordem descendente, de análise do geral para o particular, chegando-se, assim, a uma conclusão, que tem o objetivo de explicar o conteúdo das premissas, que permite a averiguação de novos eventos jurídicos a partir de axiomas e princípios já estabelecidos, sendo tal método fundamental no estabelecimento, por exemplo, de como o emprego, no sistema capitalista, é a melhor espécie de trabalho na garantia da dignidade humana, já que sua configuração 
jurídica é estruturada nos princípios de Direito do Trabalho, em especial no princípio protetor. O raciocínio indutivo, que, do estudo dos casos particulares leva a uma generalização de determinado fenômeno, poderá também ser de grande valia como método de análise científica, pois derivando de observações de casos específicos da realidade concreta (os casos particulares que determinam, quando analisados conjuntamente, estatísticas genéricas sobre o tema), pode-se chegar ao estabelecimento de dados genéricos que, no vertente trabalho, acabam por demonstrar a relação existente entre trabalho degradante e exclusão social.

Quer parecer ainda fundamental, a utilização da dialética materialista para a análise dos processos econômicos e sociais que influenciam na temática ora desenvolvida, mostrando, à guisa de exemplo, como dentro de um mesmo Organismo, idéias antagônicas podem se desenvolver a partir da mesma fonte informativa, como se dá na interpretação do conceito da OIT sobre trabalho decente.

Em relação às fontes informativas da pesquisa, pretende-se recorrer ao ordenamento jurídico nacional e internacional; à doutrina nacional e estrangeira; aos estudos desenvolvidos por órgãos ligados ao tema como o IPEA; à pesquisa jurisprudencial; à pesquisa histórica; consulta a órgãos governamentais; estatísticas realizadas por órgãos credenciados, dentre outras fontes. 


\section{TRABALHO DEGRADANTE}

\subsection{Trabalho degradante, trabalho decente e a concepção marxista de trabalho}

Pode-se perceber na temática aqui tratada que a dignidade do trabalhador tanto mais se concretiza quanto mais próximo ele se encontra das condições decentes de trabalho, e mais afastada está da concretização quanto mais o trabalhador estiver exposto às condições degradantes. Sendo assim, a antítese da dignidade do trabalhador é sua exposição a condições degradantes de trabalho. E são muito diversos os aspectos existentes na relação de trabalho que conduzem o trabalhador a indignidade e a degradação. Tratar-se-á aqui, destarte, desses elementos, com a intenção de objetivamente determinar talvez não um rol exaustivo, mas os principais fatores que tornam o trabalho degradante.

Antes de oferecer a pesquisa específica de que trata este capítulo, importante realizar alguns esclarecimentos. Há a consciência de que o trabalho subordinado no sistema capitalista jamais alcançará a plenitude de dignidade do homem, tendo em vista que esse sistema é baseado na desigualdade entre os seres humanos, na exploração do trabalho alheio.

A natureza do trabalho no modo de produção capitalista, segundo Marx, é a exploração do homem pelo homem.

Trabalho, expõe o autor em seu título O capital (MARX, 2010a, volume III), “é condição necessária do intercâmbio material entre o homem e a natureza; é condição natural eterna da vida humana"; não depende, portanto, "de qualquer forma dessa vida, sendo antes comum a todas as suas formas sociais".

Enuncia Marx que trabalho é o que garante ao homem, através de suas funções físicas e psíquicas, dominar os bens naturais, com o intuito de imprimir na natureza aquilo que sua consciência deseja e seu corpo manipula. Em suas palavras, "o trabalho é um processo de que participam o homem e a natureza, processo em que o ser humano com sua própria ação impulsiona, regula e controla seu intercâmbio material com a natureza" (MARX, 2010a, volume III).

O homem, ao manipular a natureza de modo que esta lhe sirva, lhe seja útil, o faz desenvolvendo "as potencialidades nela adormecidas" e submetendo "ao seu domínio o 
jogo das forças naturais". Assim, o homem, através de suas capacidades não só físicas e instintivas, mas também a partir de sua consciência, manipula a natureza para que esta lhe sirva. Por isso é um processo consciente, fator que diferencia o trabalho nesta perspectiva daquele executado pelo homem primitivo, e justamente por ser consciente é que só pode ser desenvolvido pelos seres humanos.

Marx (2010a) indica que o processo de trabalho é composto por três elementos, a saber: 1) a atividade adequada a um fim; 2) a matéria a que se aplica o trabalho, o objeto de trabalho; 3 ) os meios de trabalho, o instrumental de trabalho.

O primeiro elemento é o próprio trabalho, já acima definido. O segundo elemento, o objeto de trabalho, se refere a:

(...) todas as coisas que o trabalho apenas separa de sua conexão imediata com seu meio natural constituem objetos de trabalho, fornecidos pela natureza. Assim, os peixes que se pescam, que são tirados do seu elemento, a água, a madeira derrubada na floresta virgem, o minério arrancado dos filões. Se o objeto de trabalho é, por assim dizer, filtrado através de trabalho anterior, chamamo-lo de matéria-prima. Por exemplo, o minério extraído depois de ser lavado. Toda matéria-prima é objeto de trabalho, mas nem todo objeto de trabalho é matéria-prima. O objeto de trabalho só é matéria-prima depois de ter experimentado modificação efetuada pelo trabalho". (MARX, ca2004, p. 1-2)

O terceiro elemento, qual seja, o meio de trabalho, é, ainda segundo Marx

"uma coisa ou um complexo de coisas, que o trabalhador insere entre si mesmo e o objeto de trabalho e lhe serve para dirigir sua atividade sobre esse objeto. Ele utiliza as propriedades mecânicas, físicas, químicas das coisas, para fazê-las atuarem como forças sobre outras coisas, de acordo com o fim que tem em mira. A coisa de que o trabalhador se apossa imediatamente, - excetuados meios de subsistência colhidos já prontos, como frutas, quando seus próprios membros servem de meio de trabalho, - não é o objeto de trabalho, mas o meio de trabalho". (MARX, ca2004, p. 2) 
Assim, a pedra, que serve para moer, pode ser exemplo de meio de trabalho. É extraída de seu meio natural para que o homem atinja da maneira desejada seu objeto de trabalho. São os instrumentos de trabalho.

$\mathrm{Na}$ realização do processo de trabalho, ou seja, com a atividade humana operando um objeto de trabalho para que este lhe seja útil por meio de um instrumental tem como resultado um produto, ao qual Marx atribui a expressão "valor-de-uso"; para o pensador, "valor-de-uso é um material da natureza adaptado às necessidades humanas através da mudança de forma. O trabalho está incorporado ao objeto sobre que atuou. Concretizou-se e a matéria está trabalhada (...) Ele teceu e o produto é um tecido” (MARX, 2010a).

Note-se ainda que um valor-de-uso pode ser utilizado no processo de trabalho de outro valor-de-uso, ou seja, o que é o "produto de um trabalho torna-se assim meio de produção de outro. Os produtos destinados a servir de meio de produção não são apenas resultado, mas também condição do processo de trabalho". Podem ser ainda matéria-prima, na medida em que, utilizando o exemplo de Marx, "na engorda de gado, o boi é matéria-prima a ser elaborada e ao mesmo tempo instrumento de produção de adubo" (MARX, 2010a).

Como ensina Márcio Bilharinho Naves (2008), o processo de trabalho para o capitalista é tão somente a utilização da força de trabalho, "essa mercadoria que ele adquiriu no mercado e que ele consome acrescentando a ela os meios de produção" (p. 93). De tal sorte que o capitalista não fabrica um produto com fim em si mesmo ou com o objetivo de satisfazer a necessidade das pessoas. Neste sentido, os valores de uso são produzidos apenas "e na exata medida em que sejam substrato material, portadores do valor-de-troca". Os valores-de-uso fabricados pelo capitalista são mercadorias cujo valor excede o valor dos meios de produção e da força de trabalho empregada na sua produção. Assim, visa o capitalista não só um valor-de-uso, mas especialmente a mais-valia.

Nesta toada, o que se pode perceber é que a finalidade do capitalismo não é a produção em si do valor-de-uso, mas sim da mais-valia, fato determinante de todo o processo de trabalho, haja vista que "do ponto de vista do processo de valorização, não é o operário que utiliza os meios de produção, mas, ao contrário, são os meios de produção que utilizam o operário" (NAVES, 2008, p.93). A força de trabalho torna-se apenas um meio para a “valorização de valores já existentes, dos meios de produção, que utilizam esta força de trabalho para conservar e aumentar o valor neles contidos" (NAVES, 2008, p. 94).

Absorvendo o trabalho vivo, o capitalista obtém o lucro a partir da exploração do trabalhador, pois, conforme Marx (2010a, volume III, capítulo 5) “o valor da força de 
trabalho e sua valorização no processo de trabalho são portanto duas grandezas distintas. Essa diferença de valor o capitalista tinha em vista quando comprou a força de trabalho (...) O decisivo foi o valor de uso específico dessa mercadoria ser fonte de valor e de mais valor do que ela mesmo tem", ou seja, a força de trabalho produz mais valor do que ela mesma tem, por isso que é um valor que produz valores.

Continua Marx refletindo que "o possuidor de dinheiro pagou o valor de um dia da força-de-trabalho; pertence-lhe, portanto, a utilização dela durante o dia, o trabalho de uma jornada. A circunstância de que a manutenção diária da força de trabalho só custa meia jornada de trabalho, apesar de a força de trabalho poder operar, trabalhar um dia inteiro, e por isso o valor que sua utilização cria durante um dia inteiro é o dobro de seu próprio valor de um dia, é grande sorte para o comprador, mas de modo algum uma injustiça contra o vendedor" (NAVES, 2008, p. 96). Isto é o processo de produção da mais-valia. Neste aspecto, quando Marx alude que o vendedor não sofreu injustiça dentro da perspectiva do capital, já que o que se operou foi uma mera troca de equivalentes, não houve transgressão da lei, já que a força de trabalho foi remunerada ${ }^{1}$.

A mais-valia, assim, é um processo, e não um resultado. É um processo de valorização que se dá no âmbito da produção, que resulta no lucro. Assim, o capitalista "transforma, desse modo, valor, trabalho passado, objetivado, morto, em capital, em valor que se valoriza a si mesmo" (NAVES, 2008, p. 101).

O capitalista, afirma Bilharinho Naves, concretiza a "expropriação da classe operária pela burguesia completa-se: a expropriação não é apenas uma expropriação das condições objetivas do trabalho, mas é também a expropriação da subjetividade, das condições intelectuais do trabalhador" (2008, p. 101).

Se antes o trabalhador era elementar ao capital, porque detinha um conhecimento da técnica de produção, ou seja, o capital não dominava apenas as fases da produção exteriores ao processo produtivo, controlando os meios de produção e a comercialização dos produtos, mas dependia do operário que conhecia como produzir tecnicamente o produto. Assim, a mais-valia, nesse sentido, é absoluta, já que o capital, em razão da "estreiteza da base técnica de produção", somente atinge uma maior produtividade (elevando, portanto, a taxa de mais-valia) a partir da extensão da jornada de trabalho, sem o respectivo aumento de salário. Como o empregador depende do trabalhador de forma mais elementar, a mais-valia absoluta encontra fortes obstáculos, já que os trabalhadores

\footnotetext{
${ }^{1}$ Ou seja, pode-se aqui perceber que na perspectiva Marxista não há critério de justiça efetiva dentro do sistema do caital.
} 
têm poder de resistência, na forma de greve, por exemplo, e que a jornada extraordinária tem limites fáticos de extensão.

Todavia, com a introdução das novas tecnologias, novos maquinários, que substituem o trabalhador na realização da técnica produtiva, este se transforma em um "apertador de botões", ou seja, o capitalista passa a prescindir de uma extensa jornada do trabalhador, que se transforma em um "prestador de trabalho genérico, indiferenciado, desprovido de conteúdo e que não exige qualquer habilidade específica" (NAVES, 2008, p. 100).

Essa diminuição do tempo de trabalho possibilita que o capitalista extraia a mais-valia chamada relativa, pois a jornada de trabalhado não precisa mais ser extendida, mas o período de trabalho realizado e não pago - apropriado portanto pelo capital - aumenta, tornando pleno o domínio da classe burguesa sobre a classe operária.

Ilustrando com o salário, que é, a princípio, o pagamento do tempo à disposição que o trabalhador fornece ao empregador. O trabalhador recebe salário na medida em que dispõe seu tempo para de trabalho ao empregador. No entanto, o empregador não o remunera, como regra geral, pelo tempo gasto no deslocamento de casa para a empresa e da empresa para casa, a chamada jornada in itinere. Pode-se afirmar que esse deslocamento se dá única e exclusivamente para a prestação de serviços, e, seja nas grandes metrópoles, seja nos ambientes mais ermos, este tempo de deslocamento pode consumir 4 ou 5 horas diárias desse trabalhador.

Assim, apesar de não ser remunerado, esse lapso de tempo serve aos fins do capital, sem que o capital seja obrigado a remunerá-lo. Nas atividades que envolvem desenvolvimento intelectual para a realização das tarefas, o trabalhador, quando chega o término de sua jornada, muitas vezes vai para casa e passa boa parte de seu tempo de descanso raciocinando em torno daquele trabalho que ainda não concluiu, ou seja, continua trabalhando no seu tempo de folga sem ser por isso remunerado.

Esses exemplos ilustram o que é o valor excedente do trabalho, a mais-valia. $\mathrm{O}$ trabalhador despende seu tempo para realizar serviços para outrem de forma subordinada mas remunerada, remuneração esta que serve para sua vivência; ocorre que na verdade esse trabalhador acaba por realizar, como nos casos acima identificados, mais trabalho do que o contratado e sem remuneração, que é representado pelo valor excedente que se torna propriedade do empregador, que, repise-se, não o remunerou. Isso é a mais valia.

Nesse compasso, resta claro que não há de se falar em trabalho decente em relação ao trabalho abstrato identificado por Marx, ou seja, ao trabalho que designa produção dentro do sistema capitalista, onde o capital se apropria da riqueza gerada pelo operário, 
quem verdadeiramente realiza trabalho na perspectiva daquele pensador, por ser o único no sistema de produção capitalista a dominar os bens da natureza. $\mathrm{O}$ trabalho observado na perspectiva teórica marxista, que espelha a dominação e a exploração do homem pelo homem, jamais será adjetivado como decente.

Diante da perspectiva de Marx, o capitalismo é um obstáculo intransponível a existência de um processo produtivo que não tenha como resultado a degradação do trabalhador. Desde logo, afirma-se que não há de se falar em trabalho "decente", no sentido de um trabalho sem exploração do homem pelo homem.

O presente trabalho, portanto, tem como objetivo demonstrar os limites de um projeto de reforma das relações de trabalho no interior do capitalismo. Entretanto, dentre tais limites, tem-se que no capitalismo, a exploração do trabalho não se dá de forma passiva, sem a resistência do explorado. Ou seja: dentro da sociedade capitalista, a manutenção do domínio da burguesia não se pode manter apenas com o uso frequente da violência, mas também com o atendimento de reivindicações que nascem da luta da classe trabalhadora; ou seja, compreender como o trabalho decente constitui-se num corpo de práticas efetivas que têm efeito concreto sobre as condições de trabalho.

Partindo desse pressuposto, os estudos sobre trabalho decente buscam humanizar as relações desenvolvidas no capitalismo, apresentando propostas progressistas de reforma desse sistema, pois, ainda que se reconheça que este caminho jamais levará ao ideal comunista, é possível melhorar a condição do trabalhador a partir do pressuposto humanista, e é nessa vertente que se apresenta esta pesquisa.

\subsection{Trabalho degradante}

\subsubsection{Terminologia}

O presente capítulo traz em sua designação o termo trabalho degradante, e o título da presente tese adotou a terminologia trabalho decente, o que pode causar estranheza ao leitor. No entanto, tal impasse se justifica. Ao invés de, seguindo uma coerência ordinária, 
adotar o termo trabalho indecente, a opção se deu pelo vocábulo trabalho degradante, com a finalidade de afastar qualquer conotação moral que se possa inferir acerca dele.

O termo indecente é utilizado no vocábulo popular especialmente para designar algo que fere a moral comum, que é depravado. Assim, o trabalho de uma prostituta poderia ser interpretado como um trabalho indecente, assim como o trabalho de um garçom ou uma garçonete em uma casa de tolerância. Pela mesma razão, o termo trabalho indigno, utilizado por alguns doutrinadores como José Cláudio Monteiro de Brito Filho, será desconsiderado em favor da terminologia trabalho degradante. No entanto, em ambientes técnicos, o termo designaria apenas o antônimo de trabalho decente, mas para que não seja interpretado de maneira diversa da aqui indicada, a opção foi pelo termo trabalho degradante, que define aquele trabalho realizado em condições desfavoráveis ao ser humano.

Tal justificativa seria incongruente sem que se esclarecesse o motivo da opção do termo trabalho decente no título da presente tese. Na esteira do raciocínio exposto, se trabalho indecente pode comportar indesejada interpretação moral, o mesmo se pode afirmar do termo trabalho decente, ou seja, que traz uma conotação moral em seu bojo, desvirtuando assim o desejado conceito do vocábulo.

Ademais, ambos os termos são institutos de conceito aberto ou indeterminado. Um conceito aberto ou indeterminado é aquele que carece de especificação, o que dificulta sua aplicação, pela variedade de possibilidade de definições ou interpretações que pode comportar.

Notadamente, os termos trabalho degradante e trabalho decente são bastante abrangentes, podendo ser classificados como fenômenos de conceito aberto ou indeterminado.

O Direito é um ramo de conhecimento que utiliza constantemente termos abertos ou indeterminado, como família, segurança, justiça, cidadania. No conceito de Tereza Arruda Alvin Wambier (2005), termos abertos ou indeterminados são aqueles que não têm limites precisos para indicar a realidade a que se referem. No entanto, pode-se afirmar que esses termos contam com um núcleo mais objetivo, porquanto é reconhecido por um grupo social com um mesmo significado. Essa abrangência, ainda que não possa ser superada, pode ser reduzida, quando esses termos são conceituados a partir de elementos específicos passíveis de determinação na realidade concreta.

Na doutrina jurídica, não é incomum a utilização, não apenas nos textos científicos ou acadêmicos, mas inclusive no ordenamento jurídico, desses institutos de concepção 
bastante alargada. Um conceito jurídico só é reconhecido como tal, conforme já aludido, na medida em que encontra um grupo social que lhe atribui a mesma significação:

O objeto do conceito jurídico não existe 'em si'; dele não há representação concreta, nem mesmo gráfica. Tal objeto só existe, 'para mim', de modo tal; porém, que sua existência abstrata apenas tem validade, no mundo jurídico, quando a este 'para mim', por força de convenção normativa, corresponde um -seja-me permitida a expressão 'para nós'. Apenas e tão somente na medida em que o 'objeto' - a significação - do conceito jurídico possa ser reconhecido uniformemente por um grupo social poderá prestar-se ao cumprimento de sua função, que é a de permitir a aplicação de normas jurídicas, com um mínimo de segurança... O objeto do conceito jurídico expressado, assim, é uma significação atribuível a uma coisa, estado ou situação e não a coisa, estado ou situação. (GRAU, 1985, p. 218)

A opção pela utilização do termo trabalho decente se deu pela sua larga, na verdade, universal utilização, ou seja, porque sua significação é semelhante em boa parte do planeta, tendo em vista que foi mundialmente divulgado, especialmente pela OIT, e que o risco de que lhe seja atribuído um valor moral se torna bem menor, justamente porque o termo não foi difundido em si, mas com a significação conferida por aquele órgão.

Assim, aderindo à terminologia tão difundida, espera-se atingir a mesma divulgação no vertente trabalho, ou seja, o termo trabalho decente é, no entendimento indicado, o mais eficiente para a divulgação das idéias e debates aqui oferecidos, pois ao usar um termo mais preciso, como por exemplo, trabalho digno, o impacto e o alcance da divulgação possivelmente não alcançariam os patamares do primeiro, e a esperança é que esta tese científica possa contribuir para a melhoria da condição do trabalhador, a partir do reconhecimento de sua dignidade, e que quanto mais acesso obtiver, mais possibilidades se abrem para alcançar deste objetivo.

\subsubsection{Conceito}

O verbo degradar detém diversos significados (HOUAISS, 2009), indicando a privação de graus, títulos, dignidades, encargos etc., de forma desonrante; destituição, 
condenação ao exílio; degradação, banimento, desterro, tornar(-se) abjeto, infame, indigno; rebaixar(-se); aponta ainda deterioração, ato de destruir, de estragar.

Já se afirmou que o trabalho degradante, em amplo sentido, é aquele trabalho em que o indivíduo não encontra situações favoráveis para o desenvolvimento de seu labor, tanto no aspecto físico quanto no psíquico.

No entanto, esta genérica definição, pela sua amplitude, não atribui ao fenômeno contornos mais nítidos e marcados, dificultando assim seu entendimento. A tarefa ora enfrentada é a de apresentar definições mais precisas de trabalho degradante, pois, distinguindo seus traços característicos, via de consequência, identifica-se o seu contrário, o seu antagônico, que é o trabalho decente.

O Ministério Público do Trabalho oferece alguns elementos que auxiliam nessa definição, afirmando que o trabalho degradante não é sinônimo de trabalho análogo ao de escravo, porque a liberdade de ir e vir do trabalhador continua preservada, mas, no entanto, sua prestação de serviços se dá em condições não ideais.

Já o trabalho degradante é destituído do cerceamento da liberdade, ou seja, o empregado não é proibido ou impedido de exercer o seu direito de ir e vir, mas presta serviços, geralmente, em local insalubre, em jornadas excessivas, sem o fornecimento de uma boa alimentação ou mesmo de equipamentos de segurança. (MINISTÉRIO PÚBLICO DO TRABALHO, 2010)

Nesta situação exposta, poder-se-ia afirmar que o trabalhador não necessita de amparo legal, pois, se não sofre de fato a opressão do empregador na sua liberdade de ir e vir, se não estivesse anuente com aquela condição de trabalho, bastava romper e vínculo e retirar-se do estabelecimento do empregador. No entanto, tal argumento seria uma falácia, porque ignora a situação material do operário que, sem trabalho, não aufere renda sequer para manter minimamente a sua existência, e, por tal razão, acaba por se submeter às condições de indignidade.

Destarte, o fato do trabalhador ter liberdade formal não é por si elemento descaracterizador do trabalho degradante.

O Auditor Fiscal do Trabalho Dercides Pires da Silva discorre sobre o conceito de trabalho degradante: 
O que é trabalho degradante? Como identificar um trabalho degradante? Degradante é sinônimo de humilhante e deriva do verbo degradar; é o ato ou fato que provoca degradação, desonra. Degradação é o ato ou o efeito de degradar. Degradar é privar de graus, títulos, dignidades, de forma desonrante. Degradar é o oposto a graduar, a promover; degradar é despromover. Degradante é o fato ou ato que despromove, que rebaixa, que priva do estatus ou do grau de cidadão; que nega direitos inerentes à cidadania; que despromove o trabalhador tirando-o da condição de cidadão, rebaixando-o a uma condição semelhante à de escravo, embora sem ser de fato um escravo. Portanto, trabalho degradante é aquele cuja relação jurídica não garante ao trabalhador os direitos fundamentais da pessoa humana relacionados à prestação laboral. O trabalho degradante afronta os direitos humanos laborais consagrados pela Declaração Universal dos Direitos Humanos e abrigados pela Constituição da República Federativa do Brasil, assim como pela Consolidação das Leis do Trabalho e pelas Normas Regulamentadoras, as já populares "NRs", entre outras normas jurídico-laborais. Identifica-se um trabalho degradante passando a relação de trabalho pelo crivo da Declaração Universal dos Direitos Humanos (DUDH), pela Constituição da República Federativa do Brasil (CRFB), pela Consolidação das Leis do Trabalho (CLT) e pelas Normas Regulamentadoras (NR). (Silva, 2010)

Silva traz elementos concretos para a definição de trabalho degradante, delimitando-o a partir da normatização internacional e nacional que tratam do termo. Assim, trabalho decente é aquele que está em consonância com as normas de direito social, protetivas do trabalhador e reconhecedoras de sua humanidade e de sua hipossuficiência dentro da relação de trabalho, e, trabalho degradante, o exato oposto.

No entanto, apesar do prisma interessante lançado pelo Autor sobre o tema, refletindo por exemplo sobre as alterações constitucionais ocorridas em relação aos direitos sociais, como as Emendas que reformaram a Seguridade Social, dificultando o acesso aos direitos como Previdência Social, essa definição não se mostra a mais adequada, devendo ser conjugada com outros elementos que evitem esse tipo de distorção.

Senão vejamos. Com efeito, a princípio, sincronizar a definição de trabalho degradante como aquele que não é atendido pelo sistema normativo proposto (normas internacionais humanistas, CF/88, CLT e Normas Regulamentadoras do MTE) pode 
parecer suficiente, mas na realidade ignora as incompatibilidades existentes entre esses próprios elementos que compõem o sistema normativo, bem como as alterações de cunho neoliberal, economicistas e anti-sociais que vêm assolando nosso sistema normativo interno, causas que desvirtuariam essa proposta.

José Cláudio Monteiro de Brito Filho (2010, p. 61) prefere o termo trabalho indigno ao trabalho degradante. Afirma que o trabalho indigno corresponde às piores formas de exploração do trabalho, a saber: "o trabalho em condição análoga à de escravo; o trabalho com discriminação e/ou exclusão; o trabalho infantil; e o trabalho intermediado".

Brito Filho (2010) indica, sem dúvida, diversas das piores formas de exploração do trabalho, mas, crê-se, não indica um conceito ou uma definição de trabalho indigno, limitando-se a indicar algumas das suas formas. Isso porque, ao afirmar que o trabalho indigno corresponde àqueles modos de superexploração do trabalho, não o faz de maneira exaustiva, listando apenas algumas daquelas formas. Por exemplo, um trabalho pode ser livre (liberdade formal), não intermediado, onde o trabalhador não é discriminado e tem plena capacidade, mas ainda assim esse trabalho pode ser indigno, quando lhe exigem jornadas exaustivas, ou lhe assediam moralmente, etc. A lição de Brito Filho, deste modo, deve ser conjugada também com outros fatores que caracterizem mais adequadamente a indignidade nas relações de trabalho.

A proposta da vertente tese não é a de apresentar necessariamente um conceito de trabalho degradante, mas de tentar, a partir do que já foi produzido por outros pesquisadores, organizar e sistematizar seus elementos caracterizadores, trabalho este que será realizado a partir dos itens abaixo elencados.

\subsubsection{Elementos essenciais do trabalho degradante}

A partir dos conceitos, definições e formas destacadas sobre trabalho degradante, termo que por alguns doutrinadores é preterido pela designação trabalho indigno ou indecente, passar-se-á a destacar quais os elementos que essencialmente o caracterizam. 


\subsubsection{Alienabilidade}

O termo alienação pode ter diversos significados, semelhantes entre si, mas não exatamente iguais. Alienação pode significar ato ou efeito de alienar(-se); alheação, alheamento, alienamento; em termos jurídicos, transferência para outra pessoa de um bem ou direito; pode ser o estado resultante do abandono ou privação de um direito natural; no hegelianismo, processo em que a consciência se torna estranha a si mesma, afastada de sua real natureza; no marxismo, processo em que o ser humano se afasta de sua real natureza, torna-se estranho a si mesmo, pois os objetos que produz passam a adquirir existência independente do seu poder e antagônica aos seus interesses. Pode ainda significar a indiferença aos problemas políticos e sociais (HOUAISS, 2009)

Aqui se irá deter especialmente na idéia de alienação em relação ao mundo, proposta por Hannah Arendt, não sem antes estabelecer indicações relevantes acerca do termo debatido. Para Feuerbach ${ }^{2}$, os seres humanos projetavam em um ser superior, perfeito, dotado de todas as virtudes desejáveis tais como inteligência, beleza, bondade, justiça, etc., a necessidade de saber sua origem e sua finalidade, como identifica Marilena Chaui (2005), invertendo assim a ordem lógica concreta. Explique-se.

Feuerbach relata que o ser humano, para aplacar sua angústia sobre as questões da vida e da morte, sua origem, o objetivo da vida, cria e alimenta mitos como o de um ser superior que é o responsável pela criação da vida e que estabelece regras de vida e morte, ou seja, cria-se a religião como forma de conhecimento. A inversão a que se aludiu ocorre na medida em que o ser humano inverte a questão da criação, se colocando como criatura e não como criador do mito da divindade.

Esse ser perfeito e com qualidades muito superiores às humanas, como, por exemplo, a capacidade de ser onipotente, onipresente, onisciente, de controlar a vida e a morte (todas desejos humanos, portanto), não é visto como um igual, mas como um outro. Outro significa dizer um novo, uma referência indefinida fora do âmbito de referência do interlocutor, um de dois, e advém do latim altĕru de âter,ěra,ěrum ${ }^{3}$, e se diz alienus, ou seja, um ser (o ser humano) não se reconhece no outro (ser divino), e por isso se aliena.

\footnotetext{
${ }^{2}$ Cf. Teses contra Feuerbach, escrita por Marx em 1845 e publicada por Engels.

${ }^{3}$ Cf. Houaiss
} 
Alienação, desta forma, pode ser conceituada como um fenômeno de estranhamento:

\begin{abstract}
A alienação é o fenômeno pelo qual os homens criam ou produzem alguma coisa, dão independência a essa criatura como se ela existisse por si mesma ou em si mesma, deixam-se governar por ela como se ela tivesse poder em si e por si mesma, não se reconhecem na obra que criaram, fazendo-a um ser-outro, separado dos homens, superior a eles e com poder sobre eles. (CHAUI, 2005, p. 171)
\end{abstract}

O homem, a partir de sua alienação social, que permitiu a instituição da propriedade privada, passa a ser segmentado socialmente; homem rico e homem pobre, homem poderoso e homem sem poder, homem instruído e homem ignorante, etc.

A alienação econômica ocorre na medida em que o homem vende a sua força de trabalho em troca de um preço, que é o salário, alienando-se do objeto que ele mesmo produziu. Assim, aquilo que não tem preço (a condição humana) passa a ter valor atribuído pelo capital. Os produtos que realizaram são assim percebidos como alienados daqueles produtores, e chegam aos locais de consumo (mercados, shoppings) para serem vendidos, sendo certo que não são percebidos associados àqueles que os produziram, e passam a ter valor por si - são alienados daqueles trabalhadores que os produziram, e recebem também um preço. Marilena Chaui se refere a esse processo como a "mercadoria-trabalhador" que produz "mercadorias" (2005, p. 173).

Ocorre que este valor não corresponde aos valores atribuídos à produção que o homem realizou a partir do seu trabalho subordinado: ou seja, o preço atribuído à força de trabalho nunca é igual ao atribuído à produção que este trabalhador assalariado gerou. Quando este trabalhador vai consumir os produtos que produziu ${ }^{4}$, percebe que pouco pode consumir daquilo que produz, mas não atenta que essa dinâmica acontece porque seu preço (salário) é bem inferior ao dos produtos que produz, e por isso aceita esse processo de segmentação entendendo que certos produtos são designados apenas àquela parcela da população que tem poder econômico suficiente para aquela faixa de consumo, não captando que esse sistema não é natural, nem ocorre por acaso, mas sim foi instituído pela classe dominante que explora a classe dominada.

\footnotetext{
${ }^{4}$ Quando se refere aqui aos produtos produzidos pelo trabalhador, não se está indicando correspondência, ou seja, de que aquele determinado trabalhador vai consumir o produto que ele mesmo produziu, mas sim no sentido genérico de que os produtos oferecidos a consumo são produzidos pelos homens - ele enquanto classe operária e não individualmente considerado.
} 
Assim, pode-se concluir que todo trabalho mal remunerado transmuta o homem em coisa - coisificando assim a condição humana - é degradante. A fim de possibilitar a dignidade humana no sistema de produção ${ }^{5}$, a remuneração do trabalhador deve ter o condão de concretamente contemplar os elementos basilares para uma vida digna, afirmados no artigo $7^{\circ}$, IV, da CF/88:

Art. $7^{\circ}$, IV - salário mínimo , fixado em lei, nacionalmente unificado, capaz de atender a suas necessidades vitais básicas e às de sua família com moradia, alimentação, educação, saúde, lazer, vestuário, higiene, transporte e previdência social, com reajustes periódicos que lhe preservem o poder aquisitivo, sendo vedada sua vinculação para qualquer fim;

Notadamente, a preocupação do constituinte ao estabelecer esta regra foi de proporcionar ao trabalhador que, com a renda que aufere de seu labor, este possa ser capaz de atingir, para si e para sua família, os bens da vida que garantam suas necessidades vitais básicas, ou seja, institui o trabalho como um valor que concretiza outros valores como a saúde e a educação.

Ressalte-se, no entanto, que necessidades vitais básicas não são, obviamente, aquele mínimo de direitos que garantam apenas sua vida física, mas sim que abranjam todos os aspectos que tornem sua vivência plena.

Ademais, a consciência do trabalhador, antônimo, assim, de sua alienação, não é assegurada apenas por uma remuneração justa, mas ainda por tudo aquilo que possibilite àquele que trabalha conhecer sua condição humana, social, política e economicamente.

Hanna Arendt (2000), no seu A condição humana, dá um sentido muito direcionado à questão da alienação. Estabelece a referida autora que o que marca a era moderna é a alienação em relação ao mundo.

A expropriação, que é o processo de despojar determinados grupos (minoritários em poder) de seu lugar no mundo, ou seja, é um processo de exclusão, nos mais diversos sentidos, possibilitou o acúmulo de riquezas, que se transformam em capital por intermédio do trabalho. Esse ciclo possibilitou a concretização do sistema capitalista, processo que, desde a revolução industrial, mostra um grande aumento da produtividade humana. Ocorre

\footnotetext{
${ }^{5}$ Ainda que se reconheça que, seguindo a doutrina de Marx, todo trabalho dentro do sistema capitalista é degradante. No entanto, repise-se, a proposta da vertente pesquisa é oferecer uma visão reformadora, progressista, dentro da lógica do sistema imposto.
} 
que este ciclo, na verdade, gera também a alienação do homem em relação ao mundo, porque sua vida se diminui no invólucro da manutenção de suas necessidades mais básicas:

\begin{abstract}
A nova classe trabalhadora, que vivia para trabalhar e comer, estava não só diretamente sobre o aguilhão das necessidades da vida, mas, ao mesmo tempo, alheia a qualquer cuidado ou preocupação que não decorresse imediatamente do próprio processo vital. O que foi liberado no primórdio da primeira classe de trabalhadores livres foi a força inerente ao 'labor power', isto é, a mera abundância natural do processo biológico que, como todas as forças naturais - da procriação como do labor - garante um generoso excedente muito além do necessário à reprodução de jovens para compensar o número de velhos. O que torna esses acontecimentos do início da era moderna diferentes de ocorrências paralelas do passado é que a expropriação e o acúmulo de riqueza não resultaram simplesmente em novas propriedades nem levaram a uma nova redistribuição da riqueza, mas realimentaram o processo para gerar mais expropriações, maior produtividade e mais apropriações. (ARENDT, 2000, p. 267)
\end{abstract}

Continua a autora aduzindo que a apropriação não estacionou quando as necessidades e desejos foram satisfeitos; ao contrário, infiltrou-se na sociedade perpetuando um acúmulo de riquezas; esse acúmulo de riquezas, portanto, só se torna possível na medida em que em que o mundo e a "própria mundanidade do homem forem sacrificados", ou seja, em que, num primeiro momento, os trabalhadores próprios foram expropriados, inclusive da proteção da família; num segundo momento, quando a sociedade substitui a família como sujeito do processo vital, e essa possibilidade se estabeleceu pela inserção em determinada classe social, já que a proteção antes oferecida no seio familiar agora se dá pela solidariedade social, aspecto possível frente à concepção de nação. Arendt orienta que o processo de alienação do mundo pode ser ainda mais impactante:

Do mesmo modo como a família e a propriedade da família foram substituídas pela participação numa classe e por um território nacional, as sociedades circunscritas pelos estados nacionais começam a ser substituídas pela humanidade, e o planeta substitui o restrito território do Estado. Mas, o que quer que o futuro nos reserve, o processo de alienação do mundo, desencadeado pela expropriação e caracterizado por um crescimento cada vez maior da riqueza pode assumir proporções ainda mais radicais somente se lhe for permitido seguir alei que lhe é inerente. Pois os homens não podem ser cidadãos do mundo como são de seus países, e os homens sociais não podem ser donos coletivos como os 
homens que têm um lar e uma família são donos de sua propriedade privada. A ascensão da sociedade trouxe consigo o declínio simultâneo das esferas pública e privada; mas o eclipse de um mundo público comum, fator tão crucial para a formação da massa solitária e tão perigoso na formação da mentalidade, alienada do mundo, dos modernos movimentos ideológicos das massas, começou com a perda, muito mais tangível, da propriedade privada de um pedaço de terra neste mundo. (ARENDT, 2000, p. 269)

O que se pode abstrair da concepção de Hannah Arendt sobre a alienação, no que respeita às relações de trabalho, é que realmente impõem a alienação em relação ao mundo. Diversos são os exemplos concretos desta realidade, podendo iniciar esta ilustração com a questão do trabalho nos centros urbanos. As empresas se alocam em centros específicos (como no caso do ABC Paulista, ainda reduto de indústrias, ou regiões específicas de negócios, como as Avenidas Paulista e Berrini, ou ainda centros estabelecidos graças à guerra fiscal entre cidades - na região metropolitana de São Paulo estão cidades que devidos aos subsídios fiscais agregam empresas e negócios como Barueri/Alphaville), mas os trabalhadores acabam residindo em bairros afastados, marginais. Esse fato gera uma jornada in itinere, ou seja, de deslocamento de casa para o trabalho e do trabalho para casa, de mais de 5 ou 6 horas diárias. O que significa dizer que esta classe trabalhadora mais pobre, que não tem tempo, nem recurso e nem informação para participar dos fatos do mundo além do seu processo vital, num ciclo retroalimentar de alienabilidade.

\subsubsection{Insegurança no trabalho}

A insegurança no trabalho se pulveriza em diversos aspectos. Pode-se afirmar que o trabalho é inseguro no que respeita à instabilidade do emprego; às questões de insegurança física e psíquica no trabalho; à falta de correspondência concreta entre oferta da mão-deobra e contraprestação pelos serviços ofertados que mantenham sua condição de humanidade, ou seja, que garantam ao trabalhador que receberá para manter-se, a si e sua família, dignamente; à alteração in pejus das cláusulas estabelecidas no contrato; à falta de políticas públicas de emprego digno, dentre outros fatores. 
O intuito deste debate não é revisitar todas as doutrinas que apontam as condições de trabalho, mas tecer críticas e apontar dados que demonstrem como a insegurança no trabalho torna o labor degradante.

O primeiro prisma que denota a insegurança no trabalho é a possibilidade que o empregador tem de dispensar o empregado sem justo motivo, pelo simples manifestação volitiva.

Essa possibilidade, em análise mais pueril, aparenta ter sido consolidada na Constituição Federal de 1988, em seu artigo $7^{\circ}$, inciso I:

\footnotetext{
Art. $7^{\circ}$ São direitos dos trabalhadores urbanos e rurais, além de outros que visem à melhoria de sua condição social:

I - relação de emprego protegida contra despedida arbitrária ou sem justa causa, nos termos de lei complementar, que preverá indenização compensatória, dentre outros direitos;
}

Ocorre que, na realidade, a Constituição não permite a dispensa imotivada, apenas afirma que este direito será regulamentado por lei complementar, que deverá conter indenização compensatória. Se o ato merece indenização, é porque algum bem juridicamente protegido foi afetado, por uma ação do agente que não é considerada lícita. Assim, se a Constituição ordena a indenização, já vislumbra a antijuridicidade da dispensa imotivada.

$\mathrm{O}$ fato da $\mathrm{ADCT}$ da $\mathrm{CF} / 88$, em seu art. 10, I, prever que, transitoriamente, enquanto não é editada a lei complementar que efetivamente regulará a questão, a indenização pela dispensa imotivada é de $40 \%$ do valor do FGTS depositado durante o contrato de emprego, corroborou no sentido de firmar entendimento que basta indenizar para que a dispensa sem justa causa esteja assegurada.

Isso gera imensa instabilidade nas relações laborais, pois o fantasma do desemprego assola os trabalhadores, que, por este motivo, dentre outros, aceitam perversas condições de trabalho, e, mesmo se expondo a trabalhar em tais circunstâncias, podem ainda assim serem dispensado.

Em termos mais objetivos, o trabalhador é atingido em sua dignidade para manterse laborando, auferindo parca renda para sua mínima subsistência em condições adversas à sua integridade física e moral e, mesmo após tamanha exposição de sua dignidade, pode 
ser dispensado mediante pagamento de $40 \%$ do FGTS depositado durante seu contrato de trabalho.

Há de se considerar que a dignidade de quem labora, neste contexto, acaba sendo aviltada especialmente ao se considerar que a grande maioria dos trabalhadores brasileiros recebe um salário mínimo, e que poucos mantêm longos contratos de trabalho, o que significa dizer que a indenização, que por si já é depreciativa, acaba servindo muito mais como uma espécie de seguro-desemprego do que realmente indenização. Explique-se.

Indenizar, nos ensina Maria Helena Diniz (2010, p. 133), "é ressarcir o dano causado, cobrindo todo o prejuízo experimentado pelo lesado. Todavia, assume acessoriamente caráter punitivo".

Neste aspecto, a indenização compensatória de que fala a CF/88 não é contemplada pelo pagamento de $40 \%$ do FGTS, porque como efeito do baixo valor atribuído a este ressarcimento, o dano sofrido pelo trabalhador dispensado sem justo motivo não é coberto em todo seu prejuízo pelo pagamento desse montante.

Para Sílvio de Salvo Venosa (2005, p. 269), “todo prejuízo resultante da perda, deterioração ou depreciação de um bem é, em princípio, indenizável. Continua o referido Autor a explanar sobre o tema, desta vez penetrando na seara do dano imaterial, afirmando que:

\footnotetext{
A indenização em geral, por danos morais ou não, possui em si própria um conteúdo que extrapola, ou mais propriamente, se desloca da simples reparação de um dano. Costumamos afirmar que a indenização, qualquer que seja sua natureza, nunca representará a recomposição efetiva de algo que se perdeu, mas mero lenitivo (substitutivo, diriam os mais tradicionalistas) para a perda, seja esta de cunho material ou não. Desse modo, a indenização pode representar mais ou menos o que se perdeu, mas nunca exatamente aquilo que se perdeu. $\mathrm{O}$ ideal da chamada justa indenização é sempre buscado, mas mui raramente ou quiçá nunca atingido. (2005, p. 275)
}

A diferenciação atribuída por Venosa entre indenização e reparação pode indicar elemento relevante para o esclarecimento da natureza do pagamento dos $40 \%$ do FGTS. O trabalhador que não teve nenhuma mácula atribuída à sua prestação de serviços, e ainda assim foi dispensado, é atingido em sua estima, pois naturalmente o primeiro questionamento que este empregado se faz é: onde foi que eu errei? O que de fato motivou esta dispensa? Porque comigo? Estas perguntas jamais serão respondidas, e a estima do empregado, neste sentido, é diminuída.

Pode-se então concluir que o que afeta o trabalhador dispensado sem justa causa não é apenas o temor do desemprego, mas também sua estima, pois na medida em que o 
empregador não precisa justificar a dispensa, o empregado, portanto, fica sem entender se esta se deu por sua incapacidade ou por conta da organização da mão-de-obra realizada pela empresa. Seu descarte nesse contexto o leva a uma situação emocional e psíquica desfavorável.

Destarte, quando ocorre a dispensa imotivada, o empregado por ela é atingido duplamente, quanto ao medo de não atingir renda para sua sobrevivência e de sua família, e também na sua estima.

Quanto ao aspecto material, pode-se dizer, trazendo à baila o que ensina Venosa, que esta situação poderá ser reparada, mas quanto ao aspecto emocional, não há possibilidade de reparação, apenas de indenização.

Essa digressão permite interpretar o art. $7^{\circ}$, I inferindo que a norma em debate pretende não permitir a dispensa imotivada, mas apenas prevê sanção ou forma de indenização quando ela ocorre.

Ainda no debate acerca do que é o instituto da indenização, Caio Mário da Silva Pereira (2010, p. 319-320) não diferencia os termos reparação e indenização, mas informa que, descumprida a obrigação, esta deverá ser ou executada forçadamente pelo Juízo, ou o credor deverá ser indenizado. Essa indenização, segundo o Jurista, tem os seguintes fundamentos:

a) O fundamento primário da reparação está, como visto, no erro de conduta do agente, no seu procedimento contrário à predeterminação da norma, que condiz com a própria noção de culpa ou dolo. Se o agente procede em termos contrários ao direito, desfere o primeiro impulso, no rumo do estabelecido do dever de reparar, mas poderá ser excepcionalmente ilidido, mas que em princípio constitui o primeiro momento da satisfação de perdas e interesses.

b) O segundo momento, ou o segundo elo dessa cadeia, é a ofensa a um bem jurídico. É freqüente a referência a este requisito como sendo a verificação de um "dano ao patrimônio". Não nos parece bem posta a expressão, porque a referência ao valor patrimonial pode insinuar a exclusão do dever de reparar o atentado a outros valores jurídicos, de cunho não patrimonial. A nós, que nos inscrevemos entre os que admitem a indenização do dano moral, não satisfaz plenamente a idéia de restrição à reparabilidade, que admitimos mais ampla. Daí sustentamos a apuração do segundo requisito $\mathrm{cm}$ esta fórmula mais genérica, e mais elástica. Repitamos: ofensa a um bem jurídico.

c) Em terceiro lugar, cumpre estabelecer uma relação de causalidade entre a antijuridicidade da ação e o dano causado. Não basta que o agente cometa um erro de conduta e que o queixoso aponte um prejuízo. Tornase indispensável a sua interligação, de molde a assentar-se ter havido o dano porque o agente procedeu contra o direito. Na doutrina mais recente, ao interpretar o art. 403, do Código Civil de 2002, tem-se considerado que os vocábulos "direto" e "imediato" induzem à idéia de 
"necessariedade" da causa para a provocação do dano. Assim, surge a noção de nexo causal necessário, ou seja, a causalidade necessária entre a causa e o efeito danoso para a fixação da responsabilidade civil.

O primeiro ponto que merece crítica, como já inicialmente destacado, é o valor irrisório da indenização em contraponto com o direito que protege. Como se pode denotar dos conceitos colacionados sobre indenização, é cediço que indenizar significa a cobertura de todo prejuízo experimentado. No caso em tela, a indenização pela dispensa imotivada deveria cobrir especificamente o prejuízo causado àquele empregado, ou seja, estabelecer um valor genérico para a indenização da dispensa imotivada contraria a própria essência do ressarcimento. Ora, se o Direito Civil busca que a indenização cubra o máximo possível os danos específicos de quem foi atingido pelo ato ilícito, ou seja, que esta deve corresponder ao máximo às perdas sofridas pelo Autor, que dirá no Direito do Trabalho, de cristalino teor social ${ }^{6}$ ?

Sendo assim, para que a indenização pela dispensa sem justa causa surtisse efeitos jurídicos em correspondência com a finalidade do instituto, necessário se faz que este ressarcimento efetivamente cubra o prejuízo experimentado pelo empregado; tal ato teria como resultado não apenas a efetiva cobertura dos danos sofridos pelo trabalhador, mas também caráter de repressão à dispensa sem justificativa, tornando mais estáveis as relações empregatícias.

Ressalte-se que esta estabilidade no trabalho não inviabiliza que o empregador, em caso de comprovada necessidade, altere seus quadros de empregados; para ilustração desta questão, cite-se o sistema italiano de dispensa do trabalhador. A lei italiana n. 604/66 que prevê a possibilidade de dispensa do empregado, mas não única e exclusivamente pela vontade do empregador. $\mathrm{O}$ artigo $1^{\circ}$ da citada lei estabelece que:

$\mathrm{Nel} \mathrm{rapporto} \mathrm{di} \mathrm{lavoro} \mathrm{a} \mathrm{tempo} \mathrm{indeterminato,} \mathrm{intercedente} \mathrm{con} \mathrm{datori} \mathrm{di}$ lavoro privati o con enti pubblici, ove la stabilità non sia assicurata da norme di legge, di regolamento, e di contratto collettivo o individuale, il licenziamento del prestatore di lavoro non può avvenire che per giusta causa ai sensi dell'articolo 2119 del Codice civile o per giustificato motivo ${ }^{7}$.

\footnotetext{
${ }^{6}$ Todo direito, a princípio, é social porque diz respeito ao homem, mas aqui esta designação vem para estabelecer os ramos do direito cujo intuito é o amortecimento das diferenças respeitantes às partes da relação jurídica, como o Direito do Trabalho, o Direito Previdenciário, etc. e a promoção da liberdade e da igualdade material.

${ }^{7} \mathrm{Na}$ relação de trabalho por tempo indeterminado, realizada com empregadores privados ou entes públicos, onde a estabilidade não seja assegurada por norma de lei, de regulamento, e de contrato coletivo ou individual, a dispensa do prestador de serviço não pode ocorrer que não pela justa causa de acordo com o artigo 2119 do Código Civil ou por justificado motivo. (tradução nossa)
} 
A intenção dessa digressão não é realizar um comparativo detalhado com a doutrina comparada, mas demonstrar como a dispensa imotivada pode ser tratada, e por isso a exortação à lei italiana, que prevê todo um sistema de fiscalização da dispensa que não ocorrer por justa causa ou justificado motivo, na intenção de impedir o empregador, parte mais forte da relação de emprego, de exercer um poder quase que absoluto dentro desse contrato, sem uma limitação que impeça que o interesse particular se sobreponha ao público.

Ora, o emprego e a possibilidade das pessoas auferirem renda para sua subsistência e para a manutenção dos objetivos do Estado, que dependem em grande medida de arrecadação de tributos, muitos incidentes sobre o salário, manifestamente são interesses públicos; os efeitos nefastos da liberdade desmedida do empregador em dispensar seu empregado não bastassem atingir individualmente o trabalhador, se irradiam publicamente, causando assim um prejuízo mais que particular, social, que pode ser exemplificado não apenas pela arrecadação que poderá ser atingida negativamente, mas ainda pelo impacto que atos como a despedida de empregados para a contratação de trabalhadores para exercerem a mesma função, ganhando menos do que os primeiros podem atingir em relação à concorrência comercial, dentro outros tantos exemplos perverso que poderiam daí advir.

Ademais, em última instância, cabe ao Direito promover e maximizar a estabilidade social, dirimindo, diminuindo ou evitando os conflitos, e a dispensa sem nenhum motivo por certo não persegue este objetivo.

O segundo ponto, conseqüência direta do primeiro, deve ser avaliado diante da realidade do trabalhador brasileiro. Em um país que exibe altos índices de desemprego como o Brasil, imaginar que os $40 \%$ do FGTS servirão de indenização efetivamente, não é crível.

Além do valor atribuído transitoriamente pela lei de 40\% do FGTS ser genérico, não voltado para o dano efetivamente sofrido pelo empregado, seu baixo valor reforça a impossibilidade de que esse pagamento represente efetivo ressarcimento, restando quase como uma dádiva graciosa, um ato de caridade atribuído ao trabalhador, o que diminui ainda mais sua dignidade.

Isso porque diante da realidade de miséria da maioria dos trabalhadores brasileiros, a paga concedida hoje pela legislação, como visto, não o indeniza efetivamente pelos 
prejuízos experimentados, nem sequer torna-se um suporte financeiro digno para enfrentar os malefícios do desemprego, mais parecendo uma chancela legal obtusa ao dever cristão de auxiliar o próximo do que efetivo direito de ver-se ressarcido de mal que sofreu sem dar causa, ocorrido ilicitamente pela mera manifestação volitiva do empregador.

Um terceiro ponto de crítica acerca da possibilidade de dispensa imotivada diz respeito às distorções que tal fenômeno permite. Explique-se.

Um dos elementos que compõem o contrato de trabalho é a fidúcia, a confiança. Essa base de respeito e crédito entre os partícipes da relação de emprego é de tamanho significado, que sua falta pode extinguir o contrato, inclusive por justo motivo, de acordo com o ordenamento jurídico trabalhista, a exemplo do que está contemplado nos artigos 482 e 483 da CLT.

Mas o que dizer desse elemento quando há a possibilidade de o empregador, sem qualquer motivo plausível e justificado, romper este vínculo? Que confiança existe nesta instituição jurídica quando uma das partes pode romper esse vínculo sem nenhum motivo ponderado?

Considerar-se-á, neste contexto, que a quebra do contrato sem justo motivo afeta fatalmente o laço de confiança que caracteriza a relação de emprego, tornando-o inócuo, já que do empregado é exigida maior confiança que do empregador, confiança de que, ao executar corretamente seu trabalho, o empregador não vai descartá-lo sem qualquer motivo. Este ato possibilita a exploração do trabalhador além dos limites permitidos pelo direito, atingindo-o em sua dignidade.

Para ilustrar melhor tão grave afronta, pode-se exemplificar a questão com fato de ocorrência corriqueira no mercado de trabalho: dispensa sem justo motivo de empregado que labora a alguns anos no estabelecimento - e, portanto, auxiliou no processo de manutenção e crescimento da empresa - que recebe $\mathrm{R} \$ 3.000,00$ de salário-base, para contratar em seu lugar um profissional de mesmo gabarito por $\mathrm{R} \$ 2.000,00$, desconsiderando, assim, sua vertente humana para priorizar exclusivamente a lucratividade da empresa.

Um segundo exemplo que também é muito ilustrativo, diz respeito à profissão de professor. Um fenômeno interessante passou a ocorrer especialmente a partir da década de 90. Os professores mais titulados, que se qualificavam para cumprir o exercício do magistério com mais propriedade, colaborando com a doutrina pátria no sentido de criar teses inovadoras - portanto, fala-se aqui do Professor-Doutor - passaram a ser excluídos do 
mercado de ensino tendo em vista que, seu salário era sopesado de acordo com sua qualificação. Ou seja, quanto mais qualificado no profissional, mais alto o seu salário.

Muitas instituições de ensino dispensaram sem justa causa os professores-doutores de seus quadros, com o intuito de reduzir custos, sendo eles efetivamente "indenizados" com o pagamento de $40 \%$ do FGTS. No entanto, como essa prática se disseminou, esses profissionais não conseguiram se recolocar no mercado, a não ser que ou escondessem sua qualificação, apresentando apenas titulação inferior que alcança salários menores do que os de doutor, ou aceitassem, apesar de informarem sua condição de doutores, ganharem o mesmo salário dos mestres ou especialistas.

Tais exemplos refletem a relevância que o aspecto econômico adquire em contraposição ao aspecto social do trabalho, sendo o último mitigado em comparação com o primeiro. Tal desarmonia não é amparada pelo direito, como se pode depreender do pensamento de Daniel Balam (2007, p. 115), em seu artigo sobre a proteção contra a dispensa do empregado estabelecida no art. $7^{\circ}, \mathrm{I}, \mathrm{CF} / 88$ :

Para atingir o propósito deste trabalho partimos de um pressuposto inafastável: a proteção contra a despedida arbitrária ou sem justa causa é um direito constitucional fundamental. Via de regra, a 'localização' de um direito dentro da divisão metodológica do texto constitucional não é critério absoluto para se identificar sua categoria. Todavia, quando a própria Constituição expressamente insere um direito sob a rubrica dos "Direitos e Garantias Fundamentais", assim como o fez a Constituição Federal Brasileira de 1988, com o artigo $7^{\circ}$, inciso I, elimina, por certo, qualquer objeção quanto à sua fundamentalidade. Dado esse pressuposto, qualquer tentativa de interpretação do dispositivo instituidor desse direito não pode negar a força normativa que deve ter a Cosntituição, assim como ignorar os princípios próprios da hermenêutica constitucional.

Não é outra a posição de Jorge Luiz Souto Maior:

Sob a perspectiva, é crucial que se passe a considerar que a dispensa imotivada de trabalhadores não foi recepcionada pela atual Constituição Federal, visto que esta conferiu, no inciso I, do seu artigo 7o., aos empregados a garantia da "proteção contra dispensa arbitrária ou sem justa causa, nos termos de lei complementar que preverá indenização compensatória, dentre outros direitos". Ora, da previsão constitucional não se pode entender que a proibição de dispensa arbitrária ou sem justa causa dependa de lei complementar para ter eficácia jurídica, pois que o preceito não suscita qualquer dúvida de que a proteção contra dispensa arbitrária ou sem justa causa trata-se de uma garantia constitucional dos trabalhadores. Está-se, diante, inegavelmente, de uma norma de eficácia plena. 
Neste contexto pode-se ainda inserir como fator de insegurança no trabalho a política neoliberal de flexibilizar a legislação trabalhista, retirando-lhe ou diminuindo-lhe direitos com a pretensa finalidade de ampliar o mercado de trabalho, utilizando-se do seguinte raciocínio: na medida em que eu flexibilizo (barateio) o custo da mão-de-obra, abrem-se mais vagas de trabalho no mercado. Vários movimentos iniciados em plano governamental, como, por exemplo, o malfadado Projeto de Lei n. 5.483 de 2001, que tinha o objetivo de alterar o artigo 618 da CLT, para possibilitar que em sede de contratos coletivos (convenções, acordos) fosse possível qualquer alteração, inclusive confrontante Icom a Constituição Federal, desde que não atingissem normas de segurança e medicina do trabalho.

Mas claro que a definição do que são normas de medicina e segurança do trabalho não é de fácil concretização, e essa perspectiva acabaria por alargar esse conceito favorecendo, como demonstra a praxe, muito mais às questões econômicas do que às sociais. As próprias normas sobre horas extras, que instituídas no sentido de taxar de forma mais significativa a jornada mais extensa na tentativa de impedir que o empregador as solicitasse, acabaram por consolidar uma situação degradante para o trabalhador, que é assolado por seu contratante com um rol de tarefas de extensão quase impossível de ser cumprida, porque custa menos pagar a jornada extraordinária desse trabalhador do que contratar outro.

Esse trabalhador assolado de tarefas sabe da impossibilidade de cumprimento a contento daqueles afazeres, e acaba os realizando da forma que lhe é possível, ainda que não seja da forma que seria adequada, e se submete às pressões insustentáveis daí advindas, porque quando constatado o erro ou a insuficiência da operação, sabe que a cobrança recairá sobre si, e o temor do desemprego o assombra, restando-lhe conviver com a insegurança que advém dessa condição.

No que toca à segurança física e psíquica do trabalhador no ambiente de trabalho, pode-se afirmar que existem muitas normas regulando esta questão, mas nenhuma delas, mesmo quando aplicadas em conjunto, têm o condão de efetivamente garantir a segurança do trabalhador.

O trabalhador pode ser alocado em situação ou condição ambiental de risco inclusive fatal à sua vida e à saúde. Essas situações adversas são aquelas ocorridas em ambientes insalubres, periculosos, perigosos ou mesmo inadequados, ou ainda aqueles em que a saúde psíquica e emocional do trabalhador é atingidas.

Atividades ou operações insalubres são aquelas que, por sua natureza, condição ou 
métodos de trabalho, exponham os empregados a agentes nocivos à saúde, acima dos limites de tolerância fixados em razão da natureza e da intensidade do agente e do tempo de exposição aos seus efeitos, de acordo Norma Regulamentadora (NR) 15 do MTE.

Atividades ou operações perigosas são aquelas que, por sua natureza ou métodos de trabalho, impliquem o contato permanente com inflamáveis, explosivos ou radiações ionizantes, conforme dispõe a NR 16 do MTE. A Lei 7.369/85, bem como o Decreto 93.412/86 também estabeleceram que o trabalho com energia elétrica gera adicional de periculosidade.

Atividade ou operação perigosa (MAGANO, 1998, p. 54) "são as geradoras de desconforto físico ou psicológico, superior ao decorrente do trabalho normal". Podemos citar como exemplo, o trabalho dos cortadores de cana-de-açúcar, dos limpadores da parte externa das janelas de edifícios, dos professores, etc.

$\mathrm{O}$ adicional de penosidade, previsto na $\mathrm{CF} / 88$, artigo $7^{\circ}$, inciso XXIII, também mereceu a atenção do constituinte, mas, como ainda não foi regulamentado por lei, parte da doutrina e da jurisprudência entende que o artigo neste quesito não é auto-aplicável ${ }^{8}$, ou seja, que enquanto não for regulamentado por lei infraconstitucional, o adicional de penosidade não é devido. No entanto, alguns julgados prevêem a possibilidade de indenização do trabalhador exposto à situações penosas ou reconhecem a proteção

\footnotetext{
${ }^{8}$ Vide Voglia Bonfim, Sérgio Pinto Martins, etc. Na jurisprudência:
}

a) TRABALHO PENOSO. INDENIZAÇÃO. CABIMENTO. Não obstante o adicional de penosidade, previsto no art. 7o., inciso XXIII da Constituição Federal, não tenha sido regulamentado pela legislação ordinária, cabível o pleito indenizatório, quando caracterizado o trabalho penoso. Ganha relevo, nessa hipótese, o caráter pedagógico da indenização, a fim de que o empregador neutralize as condições nocivas de trabalho. (TRT $2^{\mathrm{a}}$ R., PROCESSO N $\mathbf{N}^{\mathbf{0}}$ : 00192-2008-062-02-00-5, 4 ${ }^{\mathrm{a}} \mathrm{T}$.)

b) (...) E, ainda que dependa de regulamentação infraconstitucional a compensação para o trabalho penoso fixada, pelo nosso ordenamento jurídico, a nível constitucional, (adicional de penosidade previsto no art. artigo $7^{\circ}$, inciso XXIII), não se pode deixar sem a proteção devida o trabalhador que presta serviços nestas condições. Em razão disso, há de se considerar que, na Constituição Federal de 1988, os direitos fundamentais foram erigidos à sua máxima importância, sendo que o princípio da dignidade da pessoa humana foi adotado como fundamento da República do Brasil, conforme dispõe o art. $1^{\circ}$, III, da CF/1988, constituindo a essência dos direitos fundamentais, de modo que é forçoso concluir que, se a finalidade maior da CF é tutelar a pessoa humana - a quem reconheceu direitos fundamentais -, a autonomia das relações de trabalho encontra limites na preservação da dignidade da pessoa humana. Neste contexto, verificamos que a proteção jurídica da vida, da saúde e da integridade física do trabalhador deve guardar estreita relação com a proteção dos direitos fundamentais da pessoa humana. Note-se que a CF/88, ao tutelar a saúde (art. 196), tem como finalidade a proteção da vida humana, como valor fundamental, sendo certo que a proteção constitucional se volta ao resguardo da saúde físico-psíquica do trabalhador enquanto cidadão, tanto é assim que, no inciso XXII do art. $7^{\circ}$, o legislador constituinte instituiu como direito do trabalhador a redução dos riscos inerentes ao trabalho, por meio de normas de saúde, higiene e segurança. De se concluir, assim, que o trabalho seguro e adequado constitui um direito fundamental do trabalhador (...). (TST, PROCESSO No TST-RR-174400-39.2008.5.15.0076, $8^{\mathrm{a}} \mathrm{T}$.) 
constitucional à saúde do trabalhador em sua condição humana.

O sistema de segurança e medicina do trabalho criado pela legislação permite que o trabalhador se submeta a condições que sabidamente afetarão de maneira muito significativa sua saúde; ao invés de proibir o trabalho humano nas condições adversas, apenas prevêem a utilização de equipamentos que possam diminuir ou "afastar" os malefícios que lhe são causados, ou compensações monetárias, quando muito. Afastar os malefícios causados pelo trabalho em situações adversas.

O primeiro debate que se estabelece é entender o porquê a legislação permite o trabalho em locais que concretamente atingem a saúde do trabalhador. Alguns poderão argumentar no sentido de que qualquer desgaste de energia, seja através do trabalho subordinado ou não, consome o organismo humano, o que de fato é uma realidade. No entanto, existem situações em que o trabalho humano poderia ser poupado e entregue à automação e novas tecnologias, o que não ocorre por uma simples questão de custo. $\mathrm{O}$ custo humano do trabalho é menor do que o custo com tecnologias que o substituiriam. Para cada humano que é atingido, outro está aguardando na fila - o contingente de reserva que se referia Marx.

Uma dessas situações é o trabalho com material nocivo, como o amianto ou crisotila, versão marqueteira desse produto considerado por alguns como menos nocivo que o primeiro. O problema com a utilização desse material, utilizado em pastilhas de freio, telhas e caixas de água, dentre outros, é que ele é extremamente nefasto ao organismo humano, com enorme potencial cancerígeno; mesmo que haja pouco contato com o organismo humano, esse material já manifesta esse potencial ofensivo, como se vê da descrição realizada pela ABREA:

Amianto ou asbesto é um mineral fibroso usado como matéria-prima na
maioria das indústrias e em mais de $70 \%$ das residências brasileiras. O
amianto é um material incombustível, muito resistente e suas fibras
podem ser fiadas em tecidos que suportam altas temperaturas. Porém, é
cancerígeno e provoca várias doenças graves nos seres humanos. A
contaminação se dá pelo ar que se respira ou pela ingestão de água ou
alimentos que contenham essas fibras. Os nossos mecanismos naturais de
defesa e tratamentos médicos não conseguem eliminá-lo e o mineral fica
para sempre em nosso organismo. Ao se instalar na pleura, membrana
que reveste o pulmão, ou no peritônio, membrana que reveste a cavidade
abdominal, causa doenças incuráveis, que matam lentamente ou por
asfixia ou por tumores malignos muito agressivos e de difícil tratamento.

${ }^{9}$ Cf. em $<$ http://www.abrea.com.br/tribunalconvite.htm $>$. 
Existem tecnologias para a produção de produtos sem a utilização do amianto, tanto que desde 2005 os países da União Européia não mais permitem a utilização desse material, que ainda é utilizado no Brasil, apesar de sua reprovação pública, conforme se viu no Tribunal do Amianto ocorrido na Faculdade de Direito da USP em 2005, onde, convidada para julgar se o amianto deveria ser banido no país, a população se manifestou favorável ao banimento.

A insegurança no trabalho, relacionada aos ambientes adversos, se dá primeiramente pela possibilidade do trabalhador ser alocado nessa condição que lhe atinge a saúde, ainda que potencialmente, pois o mero risco de ser morto ou de ser acometido de doença por estar trabalhando já atinge sua dignidade; no entanto, pior ainda é essa situação quando defrontada com a prescrição trabalhista. Assim, atinge-se um segundo ponto de crítica à legislação no que toca às normas de medicina e segurança do trabalho.

A CF/88 indica em seu artigo $7^{\circ}$, inciso XXIX, que prevê:

XXIX - ação, quanto aos créditos resultantes das relações de trabalho, com prazo prescricional de cinco anos para os trabalhadores urbanos e rurais, até o limite de dois anos após a extinção do contrato de trabalho;

Ocorre que o trabalhador, incontáveis vezes, percebe a doença profissional anos após ter se desligado (quer por dispensa quer por demissão) do emprego, o que significa dizer, torna impossível ver seu direito abrigado jurisdicionalmente, ou seja, sequer poderá obter do Poder Judiciário resposta objetiva de seu conflito, pois seu pleito foi atingido pela prescrição.

Imagine-se o seguinte exemplo, que é corriqueiro no ambiente de trabalho. $\mathrm{O}$ trabalhador passa boa parte de sua vida profissional, porque, afinal, é esta sua profissão, laborando em indústrias químicas, cujo meio ambiente sabidamente tem um número superior de partículas sólidas no ar que o normal. Considerando-se apenas o excesso de partículas sólidas, sem questionar se além de acumularem-se no organismo humano exalam substâncias tóxicas, pode-se afirmar com grande margem de acerto que este trabalhador irá acumular, com o passar dos anos, significativo volume de partículas sólidas no organismo, especialmente no sistema respiratório, que ficará deficiente, causando doenças como enfisema pulmonar, etc..

Apesar de o acúmulo ocorrer e ir, pouco a pouco danificando o organismo daquele trabalhador, os efeitos só serão sentidos, em grande parte dos casos, quando ele estiver 
mais, velho, ou seja, menos resistente, pois o acúmulo desse material em um curto lapso não necessariamente irá se manifestar. Assim, quando o trabalhador estiver mais frágil, tomado pela idade, não conseguirá sequer ser ressarcido do mal que lhe foi causado, pois a ação judicial possível foi atingida pela prescrição. O crédito trabalhista só poderá ser requerido, como regra geral, no prazo de dois anos a contar da extinção do trabalho.

Outra ilustração não apenas importante, mas de ocorrência cotidiana, que demonstra a insegurança no trabalho, é a possibilidade que o empregado tem de formalmente mover a reclamação trabalhista na vigência do contrato de emprego. A prescrição trabalhista atinge os direitos advindos da relação de emprego não apenas quanto ao prazo para propositura da ação ( 2 anos), mas limita também a ação somente aos créditos gerados nos últimos cinco anos de trabalho, com raras exceções como os créditos de FGTS, que têm prescrição trintenária.

Isso significa dizer que se o empregado quer reclamar os créditos advindos da relação de emprego quando completa cinco anos de trabalho e o contrato está vigente, deve fazê-lo antes que sejam atingidos pela prescrição. No entanto, como ressaltado, o contrato de emprego se mantém vigente, e o temor de ser dispensado sem justa causa, como represália pela abertura da ação, é real e concreto, sendo notório o conhecimento de que, no mais das vezes, quem propõe ação trabalhista ainda com o vínculo de emprego vigente está marcado para ser dispensado.

Não existem estatísticas oficiais contabilizando o número de processos que são movidos por trabalhadores não estáveis e com o contrato de emprego vigente, mas sem medo de errar pode-se afirmar que é um número ínfimo perto das ações movidas por aqueles que tiveram o vínculo rescindido.

O trabalhador que se mantém prestando serviços ao empregador, mesmo quando seus direitos foram descumpridos, não se sente seguro para mover a ação trabalhista, pois sabe que será dispensado, e a probabilidade de comprovação objetiva de que teve seu contrato rescindido por este motivo é mínima, o que o mantém com apenas uma possibilidade concreta, considerando que manter sua renda é vital: permitir que seus direitos sejam atingidos pela prescrição, a fim de continuar empregado.

A prática profissional advocatícia ensina que muitas empresas aguardam que determinados direitos trabalhistas sejam atingidos pela prescrição e só depois dispensam seus empregados, sabendo que, assim, não correm o risco da condenação. Observe-se que além do prazo prescricional trabalhista ser muito curto, mais uma vez, a possibilidade da dispensa imotivada tem como efeito mais perverso a insegurança no trabalho. 
Outra motivo de insegurança no ambiente de trabalho decorre da questão da aposentadoria e retorno ao mercado. Muitas vezes, o aposentado, após obter o benefício, ou continua mantendo sua relação de trabalho ou busca outra colocação de emprego. Podese imaginar, com grande grau de acerto, que o fazem com a intenção de obter renda que complemente o valor recebido no benefício previdenciário da aposentadoria.

Ora, a aposentadoria é calculada com base no fator previdenciário, formula construída para que o órgão previdenciário determine a renda do aposentado. No entanto, não são poucas as críticas dirigidas a esta equação, que para muitos é forma ilícita e injusta de atingir o cálculo de concessão do benefício, pois reduz muito o valor do benefício ${ }^{10}$. Recentemente foi prolatada decisão paradigmática pela $1^{\text {a }}$ Vara Previdenciária de São Paulo, sentença muito comemorada pelos trabalhadores e aposentados, pois indica a inconstitucionalidade do fator previdenciário:

Na lei são introduzidos elementos de cálculo que influem imediatamente
no próprio direito, concedendo-se, por via oblíqua, limitações distintas
das externadas nos requisitos impostos constitucionalmente para a
obtenção, em especial, da aposentadoria por tempo de contribuição.
Portanto, a lei ordinária acrescentou, para fins da obtenção do valor do
benefício, requisitos que, ainda que indiretamente, dificultam o acesso ao
próprio direito ao benefício. Nem se diga que uma coisa é requisito para a
obtenção do benefício - que continuaria a ser apenas o tempo de
contribuição - e outra, totalmente diversa, é o cálculo de seu valor inicial.
Ora, o raciocínio é falacioso: somente é possível se obter o benefício a
partir da utilização dos elementos indispensáveis para o cálculo da renda
mensal inicial. Assim, utilizando-se para a obtenção desta de elementos
não permitidos pela Constituição, obviamente que violado se encontra o
próprio direito ao benefício em si. (Processo no ${ }^{\circ}$ 0009542-
49.2010 .403 .6183 , Juiz Marcus Orione Gonçalves Correia)

A insegurança do trabalhador que, quando já aposentado, retorna ao mercado, pode ser identificada especialmente no caso de doença. Como já é beneficiado pelo INSS com a aposentadoria, segundo o art. 124 da Lei 8213/91 expõe, não pode ser contemplado com auxílio-doença. A regra geral é a da não cumulação de benefícios. No entanto, mesmo aposentado, continua contribuindo para o sistema da seguridade social. Contribui mas não usufrui. Senão vejamos.

O trabalhador-aposentado que fica doente não pode receber auxílio-doença, pois já recebe aposentadoria. No entanto, se este indivíduo continua trabalhando para obter renda, significa dizer que precisa de complementação do montante para atingir os bens

${ }^{10}$ Cf. Marcus Orione Gonçalves Correia. 
necessários para sua vivência, caso contrário restaria gozando do descanso obtido com sua aposentadoria. Mas, justamente nesse grande momento de fragilidade, pois, além de contar com idade mais avançada, encontra-se doente, o INSS nega o auxílio-doença com base na proibição de contemplação de mais de um benefício por pessoa, mas continua cobrando contribuição deste trabalhador, que fica desamparado contando apenas com a renda da aposentadoria.

Já se fixou que se a aposentadoria fosse suficiente, este trabalhador não retornaria ao mercado de trabalho; se o fez, foi por necessidade de complementação da renda para obter os bens necessários à vida. E justamente em momento de maior fragilidade, velho e doente, considerando-se ainda que na doença os gastos aumentem, com remédios, alimentação especial, etc., resta ao trabalhador contar apenas com o benefício da aposentadoria. Por certo, tal situação gerada na relação de trabalho indica insegurança social, infelizmente, confirmada pelo Poder Judiciário:

$\begin{array}{llllll}\text { PROCESSUAL CIVIL } & \text { E PREVIDENCIÁRIO } & \text { - AGRAVO } & \text { DE } \\ \text { INSTRUMENTO } & - & \text { CUMULAÇÃO } & \text { DE } & \text { BENEFÍCIOS } & \text { - }\end{array}$ IMPOSSIBILIDADE. A norma prescrita no artigo 124 da Lei n. 8.213/91 obsta a percepção simultânea da aposentadoria e auxílio-doença. Assim, o restabelecimento do auxílio-doença e o prosseguimento da execução determinado pela r. decisão agravada configura cumulação de benefícios, vedada por lei. Ademais, face ao instituto da coisa julgada é incabível o cancelamento da aposentadoria especial na fase da execução de sentença. Agravo de instrumento provido. (TRF3, SP, $7^{\mathrm{a}}$ T., p. 2007.03.00.0070031, AI, julg. 29/03/10)

Infinitas são as causas específicas que tornam o trabalho inseguro, sendo assim impossível listá-las; o objetivo aqui perseguido, e, espera-se, atingido, é de mostrar como o trabalho, dependendo das condições em que for desenvolvido, pode tornar-se inseguro, e, assim degradante, merecendo combate em prol da dignidade do trabalhador, na construção de um trabalho decente. 


\subsubsection{Desconstrução psíquica do trabalhador}

Normalmente, a primeira percepção que se tem dos danos que o trabalho pode causar aos obreiros é relacionada ao seu bem-estar físico, ou seja, às questões de segurança e medicina do trabalho, não apenas as que decorrem de acidentes do trabalho, mas também doenças desenvolvidas por conta do meio ambiente de trabalho.

No entanto, existe uma possibilidade de dano causado pelo trabalho que vem sendo cada vez mais analisada pelos estudiosos não apenas do direito, mas de outras searas de conhecimento como a psicologia, a sociologia, a medicina, etc. É o dano psíquico causado ao trabalhador.

As relações de trabalho, modernamente, tem se pautado por novos modelos de gestão, cujo objetivo na maioria das vezes é otimizar a produção e, concomitantemente, reduzir custos. Esse binômio, como explica Dejours, é causa de malefícios psíquicos que atingem com grande intensidade o trabalhador.

Isso porque a construção das relações dentro do ambiente corporativo, para que aquele objetivo citado seja alcançado, depende do grau de pressão com a qual o trabalhador é constrangido.

Por exemplo, pode-se indicar um trabalhador a quem foi atribuído um grande volume de trabalho, que nitidamente ele não conseguirá se desincumbir se o fizer com o grau de atenção e análise adequado. No entanto, se qualquer problema ocorrer do trabalho por ele desenvolvido, ele não poderá argumentar que realizou os trabalhos sem a atenção necessária, pois será taxado de incompetente, ou mesmo, dependendo de como o problema se desenvolveu, poderá ser dispensado sem justa causa.

Isso significa dizer que este trabalhador vive a relação de emprego esperando pela possibilidade do erro, tendo em vista que pelo grande volume de trabalho não consegue realizar as tarefas adequadamente, fato por todos conhecido mas por ninguém assumido, e, ocorrendo algum problema, será responsabilizado pelo empregador.

Perceba-se que não é uma atuação isolada de um mau empregador, mas sim uma exigência relacionada aos modelos de gestão adotados na contemporaneidade, ou seja, tanto a ação de atribuir volume de trabalho acima das possibilidades reais de realização adequada, os efeitos perversos dessa situação, que podem ser resumidos na 
responsabilização do empregado na ocorrência de qualquer problema, são fatores intrínsecos do sistema de gestão.

O trabalhador, neste contexto, fica o tempo todo de sua atuação, até de forma inconsciente, buscando um equilíbrio entre realizar todos os trabalhos que lhe são atribuídos e entre a realização das tarefas de forma adequada, que demandam um tempo que ele não possui para sua execução.

A tensão e o desgaste emocional gerados a esse trabalhador causam-lhe malefícios de ordem psicológica que podem ser externados por meio de depressões, gastrites, fobias e outras doenças relacionadas ao psíquico; este trabalhador fica constantemente com medo de errar, medo de não finalizar as tarefas, medo de ser responsabilizado, medo de ser dispensado. O medo faz parte do cotidiano do trabalhador.

Outros acontecimentos gerados no trabalho desencadeiam a desconstrução psíquica do trabalhador. Dentro de um ambiente corporativo, a angústia pela instabilidade do emprego causa, direta ou indiretamente, um medo generalizado de perder o emprego, gerando assim determinados comportamentos do grupo. Pondere-se, neste contexto, a interação entre o setor comercial e o setor jurídico de uma empresa. Um busca a venda dos produtos, atingindo o maior patamar possível de vendas concretizadas. O outro busca estabilidade e segurança nas relações jurídicas produzidas nas negociações. Os setores comerciais normalmente trabalham com metas a serem atingidas, o que faz com que seus gestores estejam sempre buscando saídas e soluções que impulsionem tais metas aos índices desejados. Seus projetos são repassados ao setor jurídico para avaliação.

A função do setor jurídico, nessa perspectiva, é de avaliar a segurança daquelas preposições, além de sua viabilidade em relação ao direito. Não é incomum que o setor jurídico seja reconhecido como aquele que inibe as relações comerciais, porque não recomenda este ou aquele projeto, por reconhecer neles impropriedades jurídicas que o maculam.

Imagine-se o relacionamento entre empregados dos dois setores, um querendo a todo custo a aprovação de seu projeto, pois seu emprego pode dele depender, e o outro sendo minucioso na avaliação, pois seu emprego dele pode depender! Esta situação piora na medida em que o analista jurídico sabe da necessidade que o colega de trabalho da área comercial tem de apresentar novos e interessantes projetos, mas ao mesmo tempo, tem que avaliar se ele é viável para a empresa, indicando eventuais riscos, sob pena de, deixando de considerar algum elemento importante, não apenas perder sua própria vaga de emprego, mas ainda ser responsabilizado por eventual erro. 
Ao invés dos setores trabalharem juntos para o crescimento da empresa, por conta da pressão ocorrida, se comportam na prática como inimigos com objetivos opostos, e, por causa dos modelos de gestão escolhidos pela empresa, acabam por se posicionar de modo não coordenado; um tentando demonstrar que o projeto tem muita viabilidade, escondendo ou tentando esconder os riscos, o outro desconfiando das informações e avaliando cada risco da maneira mais hermética a fim de não ser de nenhum modo responsabilizado.

Assim, o empregado do setor comercial é compelido a atingir metas muitas vezes não factíveis, e a projetar seu plano de ação omitindo efeitos indesejáveis que cause, inclusive a outros setores da empresa, restando então angustiado pela eventual recusa de seu projeto (que parte do infactível) ou pela eventual aceitação que pode, ao ser executado o projeto, transparecer seus efeitos maléficos.

Quanto ao empregado do jurídico, ele é hostilizado por realizar bem seu trabalho "emperrando" projetos cujo mote final é a maior lucratividade da empresa, ou penalizado com angústia e sofrimento pelo medo de sofrer a responsabilização pelo trabalho que sabe ter sido realizado de maneira inadequada, mas que supre as expectativas comerciais da empresa.

Essa situação, que ocorre cotidianamente no mundo corporativo, com mais ou menos variáveis, ocasiona outro efeito que tem grave impacto na disposição psicológica do trabalhador: a falta de reconhecimento pelo trabalho. Dejours (2007, p.34 et seq.) expõe que o reconhecimento não é uma reivindicação secundária, mas sim decisivo na dinâmica da mobilização subjetiva da inteligência e da personalidade no trabalho:

Do reconhecimento depende, na verdade, o sentido do sofrimento. Quando a qualidade do meu trabalho é reconhecida, também meus esforços, minhas angústias, minhas dúvidas, minhas decepções, meus desânimos adquirem sentido. Todo esse sofrimento, portanto, não foi em vão; não somente prestou uma contribuição à organização do trabalho, mas também fez de mim, em compensação, um sujeito diferente daquele que eu era antes do reconhecimento. [ ] O reconhecimento do trabalho, ou mesmo da obra, pode ser reconduzido pelo sujeito, ao plano da reconstrução de sua identidade. [ ] O trabalho se inscreve então na dinâmica da realização do ego. A identidade constitui a armadura da saúde mental.

Sem a dinâmica descrita, o trabalhador vê seu sofrimento acontecer em vão, ou seja, ele não consegue atribuir nenhum sentido ao sofrimento, desestabilizando-se e podendo ser conduzido, nesse compasso, à doença mental. 
O medo existente nas relações de trabalho, especialmente em situações onde o risco de vida é maior, como na construção civil, no ambiente rural, etc., faz com que o trabalhador, para continuar naquela situação - já que não há outra possibilidade mais digna, haja vista a necessidade concreta de manter-se vivo - enfrente o medo de forma paradoxal: ignorando o medo, zombando do medo, como forma de encará-lo, mas ao mesmo tempo, expondo-se ainda mais, em especial coletivamente. Dejours (2007, p. 103) esclarece este procedimento:

A psicodinâmica do trabalho descobriu também a existência de estratégias coletivas de defesa, que são estratégias construídas coletivamente. Se, mesmo nesse caso, a vivência do sofrimento permanece fundamentalmente singular, as defesas podem ser objeto de cooperação. As estratégias coletivas de defesa contribuem de maneira decisiva para a coesão do coletivo de trabalho, pois trabalhar é não apenas ter uma atividade, mas também viver: viver a experiência da pressão, viver em comum, enfrentar a resistência do real, construir o sentido do trabalho, da situação e do sofrimento.

O Autor continua sua explanação indicando que este tipo de procedimento é muito visível, como já se afirmou, em setores que mais sofrem com o risco, como o da construção civil, que pela sua própria natureza impõe um ambiente bastante perigoso aos trabalhadores, risco em altura, em lidar com materiais pesados, trabalho exposto a sol, chuva, frio, calor, inexistência ou pouca eficiência de equipamentos de segurança, organização do trabalho ineficiente, etc.

Eles opõem ao risco uma negação da percepção e uma estratégia que consiste em escarnecer do risco, em lançar desafios, em organizar coletivamente provas de encenação de riscos artificiais, às quais todos devem submeter-se publicamente segundo formulas variáveis que podem chegar até o ordálio. (2007, p. 103)

Somadas à questão da virilidade que, nesse contexto, funciona como um suplemento da coragem necessária para encarar o medo, esse mecanismo psicológico explica o porquê da resistência infundada de muitos trabalhadores em utilizar dos EPIs que lhes são concedidos pelo empregador, que inibe qualquer menção à insegurança do 
trabalho, a indisciplina em relação às normas de segurança, à fanfarrice, às provas de coragem desnecessárias, etc.

Uma pesquisa realizada por Souza Soares et al. (2007) indica que no trabalho portuário, o índice de trabalhadores que confessadamente utilizam de drogas no ambiente de trabalho é da monta de 43,14\%, sendo que, neste universo, 94,70\% utilizam o álcool como substância entorpecente, podendo ser ainda maiores os números, considerando que nem todos que utilizam as drogas confessam o seu uso, diante da negativa moral e jurídica social frente a tal prática.

Não surpreende que esta pesquisa tenha concluído que a utilização de drogas nocivas tem como um dos motivos o trabalho em locais perigosos:

O alcoolismo relacionado ao trabalho pode ser uma prática defensiva utilizada pelos trabalhadores como forma de inclusão social ou como uma maneira de viabilizar o próprio trabalho. É uma droga utilizada com maior frequiência em ocupações cuja principal característica é o desprestígio social e em situações de trabalho perigoso. (2007, p. 596)

Dejours também indica que o álcool é muitas vezes utilizado como poderoso sedativo que amortece o medo no contexto de enfrentamento do medo no ambiente de trabalho, aqui debatido:

O uso bastante difundido do álcool, que é um poderoso sedativo do medo, embora não seja identificado como tal, e protege contra o medo, respeitando ao mesmo tempo a proibição de falar nele. (2007, p. 104)

Paradoxalmente, muitas empresas que mantêm modelos de gestão que causam males como os que aqui foram ilustrados, mantém juntamente programas de motivação no trabalho. Ocorre que estes programas de motivação não subsistem quando ocorre o enfrentamento da desejada motivação com a realidade aflitiva de trabalho, ou seja, quando se salienta a "discrepância entre organização prescrita e organização real do trabalho" (DEJOURS, 2007, p. 61).

Isto significa que a organização prescrita - o que oficialmente se coloca como plano de gestão da empresa, nas mais variáveis modalidades - é distinta da organização real da empresa, pois os agentes que executam as ações de gestão são diferentes, têm personalidades distintas e, portanto, interpretam cada ponto de maneira possivelmente diversa, haja vista, como já indicado, que existem fatores subjetivos (necessidades de 
desejos pessoais) que influenciam fortemente as tomadas de decisões e as ações executórias.

Ademais, não se pode ignorar que existem determinados fatos que são por todos conhecidos, mas não podem ser falados; ou pior, devem ser ignorados e vivenciados de forma totalmente contrária à realidade. Pode ilustrar esta afirmação com um exemplo já utilizado anteriormente, mas bastante significativo: em um determinado setor da empresa, é percebido por todos os empregados que nele estão alocados que o volume de trabalho é muito superior à força de trabalho ali destinada. No entanto, o chefe da equipe jamais poderá expressar essa condição, que sabe ser concreta; ao contrário, deverá exigir cada vez mais de seus subordinados para que deem conta do serviço o máximo possível, tendo ainda ciência que esse volume de trabalho jamais permitirá a realização adequada das tarefas e que dificilmente será finalizado no tempo exigido.

Seus subordinados reconhecem os mesmos fatos, mas têm medo de serem taxados de pessimistas, de não saberem trabalhar em equipe, de não serem capazes de superar desafios - jargões dos novos modelos de gestão - fatores que podem levar-lhes ao desemprego.

Além disso, o empregado pode passar, por conta da pressão que sofre, e da postura de normalidade que todos assumem pelos motivos acima expostos, a achar que o que lhe é exigido não está acima das expectativas factíveis, e que não atinge as metas ou realiza seus trabalho medianamente por incompetência, situação reforçada pelo empregador. Sabe-se que um dos modelos atuais de gestão prega a pressão como instrumento de otimização do trabalho.

A condição de pressão e terror psicológico leva esses trabalhadores, incluindo-se aí o chefe, o superior hierárquico, a um estado emocional muito ruim, com uma série de repercussões físicas e psicológicas, que podem claramente serem atribuídas às más condições de trabalho.

Margarida Barreto ${ }^{11}$ indica em sua cartilha Suicídio e Trabalho: Homicídio Culposo Corporativo? que, de um universo de 400 trabalhadores entrevistados, sendo 84 homens e 316 mulheres, "mais de um quarto desse grupo teve idéias suicidas ligadas ao trabalho tendência proporcionalmente mais presente entre os homens $(37 \%$, ante $24 \%$ das mulheres)". Relata ainda a pesquisadora que o suicídio é a forma encontrada pelos

11 Margarida Barreto é Médica ginecologista e do Trabalho, Pesquisadora do Núcleo de Estudos Psicossociais de Exclusão e Inclusão Social (NEXIN/P.U.C- São Paulo) e Assessora técnica do Sindicato dos Trabalhadores nas Industrias Químicas, Plásticas, Farmacêuticas e Similares de São Paulo. 
trabalhadores afetados por condições psicológicas ruins de trabalho de dar voz ao sofrimento que lhes é impresso ${ }^{12}$.

Dados da OMS (Organização Mundial de Saúde) informam dados relevantes sobre o suicídio:

[...] En 2001 los suicidios registrados en todo el mundo superaron la cifra de muertes por homicidio (500 000) y por guerras $(230000)$. [ ] Las tasas tienden a aumentar con la edad, pero recientemente se ha registrado en todo el mundo un aumento alarmante de los comportamientos suicidas entre los jóvenes de 15 a 25 años. Exceptuando las zonas rurales de China, se suicidan más hombres que mujeres, aunque en la mayoría de lugares los intentos de suicidio son más frecuentes entre las mujeres. [ ]El comportamiento suicida viene determinado por un gran número de causas complejas, tales como la pobreza, el desempleo, la pérdida de seres queridos, una discusión, la ruptura de relaciones y problemas jurídicos o laborales ${ }^{13}$.

Observe-se que os dados selecionados informam que não apenas o desemprego é considerado causa do suicídio, mas também problemas no trabalho; no entanto, são poucos os estudos, como o de Margarida Barreto, que correlacionam a forma de exploração no trabalho com o suicídio.

A gestão de recursos humanos que se baseia no emprego de forte pressão no empregado como forma de motivação para o trabalho é desastroso e pode culminar no suicídio. Recentemente foram divulgadas notícias que imprimem claramente os efeitos perversos desse procedimento. É o caso da empresa Foxconn, onde, em curto espaço de tempo, ocorreram diversos suicídios entre seus trabalhadores, tendo sido atribuída como causa a péssima condição de trabalho, especialmente psicológica, a que eram submetidos.

Richard Lai ${ }^{14}$ entrevistou o repórter Liu Zhiyi, que se infiltrou por 28 dias na referida empresa com a finalidade de averiguar se as condições relatadas eram realmente ruins. Descobriu que os empregados ganham em média US\$132,00 acrescidos das horas

${ }^{12} \mathrm{Cf}$. em $<$ http://www.redebrasilatual.com.br/revistas/52/pressao-fatal $>$.

13 [...] Em 2001, os suicídios no mundo ultrapassaram o número de mortes por homicídio (500 000) e guerra (230 000). [ ] As taxas tendem a aumentar com a idade, mas recentemente tem havido em todo o mundo um aumento alarmante em comportamentos suicidas entre jovens de 15 a 25 anos. Com exceção da China rural, os homens cometem mais suicídio que as mulheres, embora na maioria dos lugares as tentativas de suicídio são mais comuns entre as mulheres. [ ] O comportamento suicida é determinado por uma série de processos complexos, tais como pobreza, desemprego, perda de entes queridos, uma discussão, a ruptura de relacionamentos e problemas legais ou no trabalho. (tradução nossa)

${ }^{14}$ Cf. o relato completo em < http://www.engadget.com/2010/05/19/the-fate-of-a-generation-of-workersfoxconn-undercover-fully-tr/>. 
extras. Quando são contratados assinam um documento onde "voluntariamente" abrem mão do limite legal de 36 horas de trabalho. O que significa dizer que para angariarem dinheiro para que possam minimamente sobreviver, devem fazer muitas horas-extras, chegando ao ponto de não conseguirem gozar adequadamente de feriados como o $1^{\circ}$ de maio (dia do trabalho), por ser um dia a menos de horas extras realizadas e ganhas:

Each employee would sign a "voluntary overtime affidavit," in order to waive the 36-hour legal limit on your monthly overtime hours. This isn't a bad thing, though, as many workers think that only factories that offer more overtime are "good factories," because "without overtime, you can hardly make a living." For the workers desperate for making money, overtime is like "a pain that can breathe:" without it, the days without money make them "suffocate;" with it, the restless work would only add more "pain" to the body, thus aging quicker. Most of the time they staunchly choose the latter, but even the right to choose such isn't available to all. Only those with the seniors' "trust," with good connections, or those in key positions, can often get to work overtime.

So, the "May 1st" [Labour Day] festival is a concern for some, because it's "hard to boil through" the days when you spend money without making any. That day, workers would rather not celebrate any festival, and wish for more overtime pay; the reality is they can't [choose], so might as well just have a lie-in ${ }^{15}$.

Pode-se imaginar o embate mental desse trabalhador, instado a escolher entre descansar seu corpo, que está no limiar da exaustão, ou continuar trabalhando para obter minimamente os bens da vida para sua sobrevivência, quase sem realmente ter chances de mudar esta condição. Conforme amplamente divulgado nos meios de comunicação ${ }^{16}$, onze suicídios ocorreram este ano apenas, chamando a atenção da comunidade internacional, e

\footnotetext{
${ }^{15}$ Cada funcionário assina uma "declaração prorrogação voluntária", a fim de dispensar o limite legal de 36 horas em sua jornada extraordinária mensal. Esta não é uma coisa ruim, porém, muitos trabalhadores pensam que só as fábricas que oferecem mais horas extras são "fábricas boas", porque "sem horas extraordinárias, dificilmente você pode fazer uma vida". Para os trabalhadores desesperados para fazer dinheiro, horas extras são como "uma dor para respirar": sem ela, os dias sem dinheiro os sufocam; o trabalho frenético só adiciona mais "dor" para o corpo, envelhecendo-o mais rápido. Na maioria das vezes eles firmemente escolhem essa opção, mas o direito de escolher não é disponível para todos. Apenas aqueles de "confiança" dos chefes, com boas ligações, ou aqueles em posições-chave, podem começar a trabalhar na jornada extraordinária. Assim, o "01 de maio" (Dia do Trabalho) é uma preocupação para alguns, porque é "difícil de comemorar" os dias em que você gasta o dinheiro sem fazer nenhum. Naquele dia, os trabalhadores preferem não comemorar qualquer festa, desejando mais pagamento de horas extras, a realidade é que não podem (escolher), então podem muito bem ficar um pouco mais na cama. (tradução nossa)

${ }^{16} \mathrm{Cf}$. em <http://dementia.pt/os-suicidios-na-foxconn/>, <http://noticias.bol.uol.com.br/internacional /2010/05/28/suicidios-da-foxconn-revelam-as-duras-condicoes-de-trabalho-na-china.jhtm,>.
} 
revelando que anteriormente já haviam ocorrido outros suicídios creditados à militarização da gestão humana, aos maus tratos psicológicos, etc.

A empresa chegou mesmo a circular um comunicado em 25.05.10, referindo-se ao ocorrido, onde solicitava que os empregados se comprometessem a "não se machucar", a "aceitar serem enviados ao hospital em casos de problemas mentais" e a não "processar a empresa fazendo exigências excessivas de indenizações". O presidente da empresa, Terry Gou, reconheceu que o comunicado era "grosseiro", e prometeu "drásticas medidas", que corresponderam ao oferecimento de mais psicólogos aos trabalhadores e a inserção de uma rede de segurança externa no prédio do dormitório dos trabalhadores.

O que choca é que não há notícias de que seriam melhoradas as condições de trabalho desses empregados.

Uma condição psíquica de trabalho ruim, ao contrário do que se pode imaginar, não atinge o trabalhador apenas emocionalmente, mas também em sua conformação física, como se pode denotar:

Ocorrem com freqüência distúrbios no aparelho digestivo, ocasionando bulimia, problemas gástricos diversos e úlcera. Sobre o aparelho respiratório a queixa mais freqüente é a falta de ar e sensação de sufocamento. Sobre as articulações podem ocorrer dores musculares, sensação de fraqueza nas pernas, sudorização, tremores, como também dores nas costas e problemas de coluna. Sobre o cérebro verificam-se ânsia, ataques de pânico, depressão, dificuldade de concentração, insônia, perda de memória e vertigens. Sobre o coração os problemas podem evoluir de simples palpitações e taquicardias para o infarto de miocárdio. E o enfraquecimento do sistema imunológico reduz as defesas e abre as portas para diversos tipos de infecções e viroses. (Guedes, 2008, p. 108)

Esse fenômeno é conhecido como somatização, que "corresponde a uma tendência de experimentar e de comunicar distúrbios e sintomas somáticos não explicados pelos achados patológicos, atribuí-los a doenças físicas e procurar ajuda médica para eles". Continua o referido Autor informando que "é usualmente assumido que essa tendência torna-se manifesta em resposta a estresse psicossocial acarretado por situações e fatos da vida particularmente importantes para o indivíduo”. (BOMBANA, 2001)

Bombana afirma que a somatização pode ocorrer de diversas formas, a saber: a) como um modo de expressar-se (uma variação individual normal); b) indicando uma doença orgânica ainda não diagnosticada; c) como parte de outras patologias psiquiátricas (ex: depressão); d) como um transtorno somatoforme. 
Note-se que ao menos duas dessas formas podem ser relacionadas diretamente com as más condições psicológicas de trabalho, a somatização como expressão da angústia e como parte de outra patologia psiquiátrica como a depressão. O Decreto 3048, em seu anexo II reconhece a depressão como doença do trabalho, devendo o tema merecer, assim, estudos mais aprofundados, não apenas para a fortalecimento desse reconhecimento mas principalmente sobre quais são os efeitos jurídicos que daí podem decorrer para a proteção do trabalhador.

Resta identificada, assim, a desconstrução psíquica do trabalhador como elemento caracterizador do trabalho degradante.

\subsubsection{Dessocialização}

O trabalho tem o condão de sociabilizar o homem, em dois aspectos. O primeiro deles, é que o ser humano passa uma grande parte de seu tempo no trabalho, motivo pelo qual é naquele ambiente que promove boa parte de sua sociabilização, devendo, portanto, ser promovida pelo empregador e pelo Estado essa conseqüência desejável do trabalho. O segundo aspecto da sociabilização decorre do tempo em que se passa no trabalho, porque, se é fato que o ser humano passa em média 8 horas de seu dia (1/3, portanto) laborando, é certo que precisa de tempo adequado para o descanso e para a convivência social em outros meios, como no ambiente familiar, no ambiente comunitário, etc. Sendo assim, um trabalho pode ser considerado degradante se não permite a sociabilização pelo trabalho e, ao mesmo tempo, não permite, pelo tempo gasto com o labor, que as outras formas de coexistência social se desenvolvam. Para que o trabalho seja considerado decente, é necessário que haja um sopesamento entre esses dois fatores indicados.

A dessocialização no ambiente de trabalho é fator de degradação do ser humano. Sabidamente, uma das formas do homem se socializar, criar laços de fraternidade, amizade, de trocar socialmente, é a convivência social advinda do ambiente laboral. Considerando a jornada legal básica brasileira, instituída pela $\mathrm{CF} / 88$, de 8 horas por dia, um trabalhador passa em média 1/3 de seu tempo no trabalho. Só por esta perspectiva já se descortina o tema que será doravante enfrentado. 
Ressalte-se ainda que as discussões aqui apontadas, longe de serem exaustivas, servem tão somente como ilustração da temática desenvolvida, tendo por objetivo a pontuação de como o trabalho que não socializa é degradante.

Não é incomum que o ser humano conviva mais tempo com os companheiros de trabalho do que com a própria família, pelo modo que se opera a prestação de serviços subordinado. Mesmo acompanhando determinadas mudanças sociais, como o teletrabalho ${ }^{17}$, o trabalho a domicílio ${ }^{18}$, etc., a grande maioria dos trabalhadores ainda presta seus serviços no estabelecimento da empresa, ou, no caso do doméstico, na residência de seu patrão. O que comprova que boa parte de sua convivência social, como acima aludido, se desenvolve no ambiente de trabalho, que é meio de integração do trabalhador, devido ao valor que lhe é atribuído pela sociedade.

O primeiro ponto a ser enfrentado diz respeito à exclusão de certas minorias do mercado de trabalho, como mulheres, negros e pessoas com deficiência, dentre outras.

Estima-se que no Brasil, segundo censo realizado pelo IBGE $^{19}$ em 2000, 14,5\% da população tem deficiência física ou mental. Dos 26 milhões de trabalhadores formais do país, apenas 537 mil são pessoas com deficiência, correspondendo a 2,05\% dessa amostragem. Rio Grande do Sul, São Paulo e Distrito Federal apresentam as maiores taxas de contratação dessa população em vagas formais. As menores taxas são dos Estados de Rondônia, Tocantins e Piauí ${ }^{20}$.

Mesmo com a inserção de política de $\operatorname{cotas}^{21}$ de trabalho para pessoas com deficiência proposta pela Lei $8213 / 91$ em seu artigo $93^{22}$, bem como com o art. 36 do

\footnotetext{
${ }^{17}$ Teletrabalho é a modalidade de execução da prestação de trabalho em que as tradicionais dimensões de espaço e de tempo resultam modificadas, com a adoção de novos procedimentos de organização e desenvolvimento das atividades laborais. Pode ser conceituado, assim, como toda forma de trabalho a distância, desenvolvido por meio de uso das tecnologias de informática e telemática. (SILVA, 2004, p.122)

${ }^{18}$ Trabalho subordinado realizado no domicílio do trabalhador.

${ }^{19} \mathrm{Cf}$. In: < http://www.ibge.gov.br/home/presidencia/noticias/27062003censo.shtm>. O censo 2010 não está concluído, motivo pelo qual foram utilizados os dados do censo 2000.

${ }^{20} \mathrm{Cf}$. In: < http://www.fgv.br/cps/deficiencia_br/PDF/PPD_Sumario_Executivo.pdf>.

${ }^{21}$ Tb. reconhecida como ação afirmativa. Nos dizeres de Bergmann, "Ação afirmativa é planejar e atuar no sentido de promover a representação de certos tipos de pessoas, aquelas pertencentes a grupos que têm sido subordinados ou excluídos, em determinados empregos ou escolas. É uma companhia de seguros tomando decisões para romper com sua tradição de promover a posições executivas unicamente homens brancos. É a comissão de admissão da Universidade da Califórnia em Berkeley buscando elevar o número de negros nas classes iniciais [...]. Ações Afirmativas podem ser um programa formal e escrito, um plano envolvendo múltiplas partes e com funcionários dele encarregados, ou pode ser a atividade de um empresário que consultou sua consciência e decidiu fazer as coisas de uma maneira diferente. (1996, p.7)
}

22 Art. 93. A empresa com 100 (cem) ou mais empregados está obrigada a preencher de 2\% (dois por cento) a $5 \%$ (cinco por cento) dos seus cargos com beneficiários reabilitados ou pessoas portadoras de deficiência, habilitadas, na seguinte proporção: 
Decreto 3298/99, que traz a mesma regulamentação em relação à Lei 7853/89, a pessoa com deficiência ainda é cotidianamente excluída do mercado de trabalho. Algumas empresas, por não compreenderem exatamente o que significa a inserção, ou mesmo porque não desejam participar desse processo, optam por contratar e pagar um salário mínimo ao empregado-deficiente para que ele fique em casa. Destarte, a empresa acredita que cumpre formalmente a cota, mas não aloca o deficiente no ambiente laboral, fazendo com que ele se sinta incapaz, humilhado e claramente excluído, deixando de participar daquele ambiente e de se socializar.

Outros empregadores optam por continuar arcando com o pagamento de multas e demais sanções impostas por lei para não contratar o deficiente, ou estabelecer critérios descabidos e inadequados, a fim de burlar a própria lei, impondo às pessoas com deficiência exigências impróprias objetivando que tais pessoas não alcancem os postos de trabalho formalmente abertos, obstaculizam assim a principal meta da lei, que é a socialização do aludido grupo. É o que demonstra a jurisprudência:

AÇÃO ANULATÓRIA DE AUTO DE INFRAÇÃO.
CONTRATAÇÃO
ESPECIAIS. DE
DESRESPEITO ADMINISTRATIVO. Não há lugar, em sede de ação anulatória de Auto de Infração, para perquirir razões invocadas como "força maior", mas que na verdade traduzem embaraços criados pelo próprio empregador ao preenchimento da cota dos portadores de necessidades especiais. Sendo o ato administrativo revestido da presunção de legitimidade e veracidade, constituído sem qualquer mácula aos requisitos do artigo 629 da CLT, e havendo o descumprimento objetivo ao preceito legal, não merece acolhida a pretensão anulatória. Ademais, a intenção do artigo 93 da Lei 8.213/91 é a inserção do portador de deficiência no mercado de trabalho, o que há de se tornar letra morta, a ser tolerada a possibilidade de o empregador rejeitar este ou aquele candidato, invocando a falta de aptidões específicas ou exigindo seleção por refinados critérios. Recurso ordinário provido, para declarar subsistente o Auto de Infração e correlato Termo de Inscrição de Dívida Ativa. (TRT 15 a , PROCESSO TRT / 15 REGIÃO Nº077900-27.2009.5.15.0026, $2^{\mathrm{a}}$ TURMA - $4^{\mathrm{a}}$ CÂMARA)

III - de 501 a 1.000 $4 \%$

IV - de 1.001 em diante. $.5 \%$

$\S 1^{\circ}$ A dispensa de trabalhador reabilitado ou de deficiente habilitado ao final de contrato por prazo determinado de mais de 90 (noventa) dias, e a imotivada, no contrato por prazo indeterminado, só poderá ocorrer após a contratação de substituto de condição semelhante.

$\S 2^{\circ} \mathrm{O}$ Ministério do Trabalho e da Previdência Social deverá gerar estatísticas sobre o total de empregados e as vagas preenchidas por reabilitados e deficientes habilitados, fornecendo-as, quando solicitadas, aos sindicatos ou entidades representativas dos empregados. 
Ementa: I - AGRAVO DE INSTRUMENTO - EMPRESA DE VIGILÂNCIA - VAGAS DESTINADAS A PESSOAS PORTADORAS DE DEFICIÊNCIA - ARTIGO 93 DA LEI ${ }^{\circ}$ 8.213/91 - CÁLCULO DO PERCENTUAL. Demonstrada violação legal e constitucional, dá-se provimento ao Agravo de Instrumento para mandar processar o apelo denegado. II - RECURSO DE REVISTA EMPRESA DE VIGILÂNCIA - VAGAS DESTINADAS A PESSOAS PORTADORAS DE DEFICIÊNCIA - ARTIGO 93 DA LEI No 8.213/91 - CÁLCULO DO PERCENTUAL 1. A empresa que contar com 100 ou mais trabalhadores deverá obedecer a um percentual mínimo de empregados portadores de necessidades especiais, segundo o disposto no art. 93 da Lei ${ }^{\circ}$ 8.213/91. 2. A referida norma é de ordem pública e não excetua do seu âmbito de aplicação as atividades de vigilância. Recurso de Revista conhecido e provido. (TST, PROCESSO $\mathrm{N}^{\mathrm{o}}$ TST-RR-43740-09.2007.5.10.0018, $8^{\mathrm{a}} \mathrm{T}$.)

Os termos de ajuste de conduta firmados perante o Ministério Público do Trabalho também ilustram o descaso das empresas em cumprir a cota da Lei 8213/91, como demonstra o compromisso firmado entre a empresa Pepsico e o MPT:

Em razão do não cumprimento do aditamento de 30 de janeiro de 2008 (g.n.), e sem prejuízo do previsto neste novo aditamento, a empresa se compromete a doar à Fundação Faculdade de Medicina - Hospital de Reabilitação Lucy Montoro, o valor de $\mathrm{R} \$ 250.000,00$ (duzentos e cinquenta mil reais) para aquisição de equipamentos de reabilitação utilizados pelo hospital. (aditamento final n. 126/2010 ao termo de compromisso de ajustamento de conduta $\mathrm{N}^{\circ} 29 / 2008$ )

A falta de contato com o deficiente faz supor erroneamente que este é incapaz, que sua produtividade é baixa, que a empresa será prejudicada na contratação de um deficiente. Exatamente o contrário do que demonstram as estatísticas, onde se vê que 9,90\% das empresas consideravam a produtividade das pessoas com deficiência acima da média, $88,63 \%$ na média e $2,27 \%$ abaixo da média, índices balizados em razão da produtividade dos empregados não deficientes (AMARAL, 1994, p. 134). O que significa dizer que o preconceito firmado frente às pessoas com deficiência não corresponde à realidade, e que sociabilização do deficiente pelo trabalho não apresenta resultados positivos somente perante este trabalhador, mas também em relação à produtividade almejada pelo empregador.

Os dados obtidos no vertente trabalho permitem a inferência de que se o meio ambiente de trabalho não reflete a diversidade que existe na sociedade, reiterando assim os 
preconceitos e a discriminação sofridos pelos grupos minoritários ${ }^{23}$, ele degrada a condição humana, e, dos vários efeitos perversos que advêm da exclusão social destes grupos, um deles é a dessocialização no ambiente de trabalho.

$\mathrm{Na}$ mesma situação das pessoas com deficiência enquadram-se os negros, as mulheres, os jovens, os idosos, os homossexuais, dentre outros grupos hostilizados no mercado de trabalho ${ }^{24}$.

No caso dos negros, o principal motivo da dessocialização é o preconceito e a discriminação, sendo certo que existem diferenças terminológicas entre os dois termos. Preconceito é a sentimento ou opinião intolerante em relação a alguém, sem que esta se manifeste externamente, e discriminação é a expressão externa do preconceito.

Conforme estatísticas da Pesquisa de Emprego e Desemprego (PED) do DIEESE (2010a), dos ocupados (100\%) da região metropolitana de São Paulo em 2009, apenas $34,2 \%$ são negros, contra 65,8\% não-negros. No caso das mulheres, que correspondem a $45,3 \%$ do total de ocupados, apenas $15,5 \%$ são negras, contra $29,8 \%$ não-negras.

O DIEESE (2008) concluiu que 42,9\% dos desempregados na região metropolitana de São Paulo eram negros, percentual bastante elevado. O mesmo Órgão (2009) indica que o negro passa mais tempo no trabalho (44 horas por semana) que o não-negro (43 horas semanais). No setor de serviços, a diferença é mais acentuada, sendo que os negros laboram 43 horas por semana e os não-negros 41 horas por semana.

Note-se que a socialização não resta aplicada apenas na questão da garantia de emprego para essa minoria, mas ainda da qualidade da convivência no ambiente de trabalho. A empresa deve manter-se atenta, dado à titularidade do exercício do poder diretivo que mantém, em fiscalizar o ambiente de trabalho, garantindo a integração de todos os trabalhadores, para que, com o contato freqüente entre todos os empregados, quaisquer discriminações possam ser afastadas.

Em relação às mulheres, o DIEESE demonstra que em 2009 representam 43,5\% do total da força de trabalho na região metropolitana de São Paulo. Considerando a participação feminina nos setores de atividade econômica, a maior desproporção em relação aos homens se dá na construção civil; enquanto eles ocupam 92,7\% dos postos, elas ocupam 7,3\%. Já no setor doméstico, as mulheres representam 96,2\%, enquanto

\footnotetext{
${ }^{23} \mathrm{O}$ termo minoritário não reflete concretamente os grupos que sofrem preconceito, haja vista que não são exatamente parcela ínfima da população, como demonstra o Censo 2000 ao verificar que mais de $14 \%$ da população brasileira sofre de deficiência; mas foi utilizado por identificar tais grupos, por força de sua ampla divulgação.

${ }^{24}$ Optou-se por exemplificar a dessocialização no ambiente de trabalho a partir dos grupos mais reconhecidos, quais sejam, negros, mulheres e pessoas com deficiência.
} 
apenas 3,8\% dos homens laboram nesta ocupação, dados que demonstram o peso que os aspectos culturais podem exercer em relação ao trabalho da mulher. Explique-se.

Conforme dados estatísticos colhidos (DIEESE, 2009, 2010a, 2010b), ainda existem setores da economia em que a participação da mulher é ínfima, por questões culturais de discriminação, em uma sociedade que ainda é patriarcal. Mesmo que a luta feminina tenha atingido importantes vitórias com objetivo de igualdade entre gêneros, e mesmo com a inserção maciça da mulher no mercado de trabalho, especialmente a partir das grandes guerras mundiais, existem nichos onde a preponderância do trabalho masculino é patente.

Em todos os setores econômicos da pesquisa (indústria, comércio, serviços, construção civil, trabalho domésticos e outros), a mulher tem menos participação que o homem, com exceção do trabalho doméstico. Particularmente, destacam-se os setores da construção civil e do trabalho domésticos, na sequiência, nichos historicamente masculino e feminino, onde se encontram as maiores desproporções de ocupação em razão do sexo. O que significa dizer que, mesmo na contemporaneidade, a mulher encontra dificuldade de expandir seu universo laboral, sendo desfavorecida quanto à possibilidade de ampliação de convivência social nos mais diversos setores da economia, fator que contribui para sua dessocialização.

Mais especificamente, um dos principais fatores de dessocialização da mulher no ambiente de trabalho, por mais paradoxal que possa soar, é o momento da gestação. Novamente, por preconceito e ignorância, a mulher grávida não raramente sofre terríveis discriminações no ambiente laboral, que refletem claramente na questão da socialização. A gestação é interpretada pelo empregador como um momento de fragilidade da mulher que não deve ser amparada socialmente, mas sim excluída do ambiente laboral, como se a empregada gestante fosse incapaz para o trabalho. Sendo assim, a gestante muitas vezes é propositalmente afastada da convivência social no trabalho, para que, pressionada pela condição degradante que lhe foi imposta, peça demissão. É o que revela o julgado abaixo colacionado:

As provas carreadas aos autos às fls. 118/120, demonstram que não ocorreu a justa causa pretendida, eis que a reclamada não comprovou a ocorrência dos motivos ensejadores, ou seja, insubordinação, desídia e indisciplina, ao contrário, restou demonstrado que a autora sofreu tratamento discriminatório, quando foi colocada para trabalhar numa mesa vazia, isolada em uma sala, ficando sem fazer nada durante 
todo o expediente. (g.n.) Apenas de passagem a testemunha da ré mencionou "que viu a reclamante rindo do patrão porque este achava ruim porque ela ia trabalhar" (fl. 119), fato que não pode justificar a falta grava imputada. (TRT 2a Região, Acórdão $n^{\circ}: 20100474564$ )

Note-se que a falta de convivência, como afirmado pode advir tanto da não contratação (desemprego), quanto da contratação que apenas se formaliza, mas não tem efetividade ou mesmo do empregado que sofre da falta de socialização a partir de práticas discriminatórias ou de assédio moral no ambiente laboral.

Outro aspecto desfavorável da relação de emprego que prejudica a convivência social, é a forma como a gestão empresarial da mão-de-obra estabelece as jornadas de trabalho. Historicamente, as longas e extenuantes jornadas foram objeto das primeiras reivindicações trabalhistas, por causarem manifesto mal à saúde do trabalhador. Foi através de luta social que se estabeleceu limitação legal às horas de prestação de serviços. Assim, pode-se crer que o legislador, ao taxar a jornada extraordinária, mais que indenizar o trabalhador vislumbrava obstaculizar essa ação solicitada pelo empregador, sob o raciocínio econômico de que, valorando a hora extra, o empregador deixaria de requerê-la cotidianamente.

As jornadas extenuantes ${ }^{25}$ não causam apenas malefícios em relação ao estado físico e mental do organismo humano, mas também dificultam sua convivência com a família e com os amigos ou em outras atividades como a escola, que, além de garantir educação, também é espaço de contato; dificultam não somente pela extensão, mas também pelo tipo de jornada estabelecido (turnos ininterruptos) e pelo período em que é desenvolvido (jornada noturna).

A extensão do tempo de trabalho é limitada pela Constituição Federal, em seu art. $7^{\circ}$, XIII, que estabelece que a jornada seja de 8 horas diárias e 44 horas semanais como regra geral:

\section{XIII - duração do trabalho normal não superior a oito horas diárias e quarenta e quatro semanais, facultada a compensação de horários e a redução da jornada, mediante acordo ou convenção coletiva de trabalho;}

\footnotetext{
${ }^{25}$ A jornada extraordinária também foi debatida na vertente pesquisa no item insegurança no trabalho.
} 
No entanto, tal regra encontra interpretações que admitem a extensão da jornada por 44 horas semanais sem atender à limitação diária, o que, quer parecer, fere o texto constitucional, independentemente da instituição de banco de horas. O TST já se manifestou neste sentido emitindo a Súmula 85, III:

\section{TST Enunciado $n^{0} 85$ (...) \\ III - O mero não-atendimento das exigências legais para a compensação de jornada, inclusive quando encetada mediante acordo tácito, não implica a repetição do pagamento das horas excedentes à jornada normal diária, se não dilatada a jornada máxima semanal, sendo devido apenas o respectivo adicional. (ex-Súmula $\mathrm{n}^{\circ} 85$ - segunda parte - alterada pela Res. 121/2003, DJ 21.11.2003) (g.n.)}

A CLT prevê a possibilidade da jornada diária se estender por duas horas, conforme disposto em seu artigo 59:

Art. 59 - A duração normal do trabalho poderá ser acrescida de horas suplementares, em número não excedente de 2 (duas), mediante acordo escrito entre empregador e empregado, ou mediante contrato coletivo de trabalho.

Assim, a limitação da jornada de trabalho em oito horas pode ser estendida para dez horas diárias, mediante acordo de compensação. Um simples exercício matemático ilustra a teoria aqui debatida. Um trabalhador com jornada estendida de 10 horas diárias, e que gasta 4 horas de deslocamento diário para ir e vir do trabalho, fica voltado para a prestação de serviços 15 horas, contabilizando o intervalo mínimo de uma hora para descanso e refeição. Restam-lhe apenas nove horas para descanso e convivência. Considerando ainda o tempo de sono médio orientado pela medicina, 8 horas, este trabalhador tem uma hora para tomar banho, jantar e conviver com sua família e amigos.

Não é incomum que estudantes tenham de abandonar os estudos porque não dispõem de tempo para, concomitantemente, trabalhar e estudar. Se não trabalham, não auferem renda para estudar e para manutenção da vida, tendo de optar, assim, pelo labor em detrimento do estudo. Não é à toa que a nova Lei de Estágio (L. 11.788/08) estabeleceu limites à jornada de trabalho do estagiário, que no máximo poderá realizar 6 horas de trabalho diárias. 
Com a possibilidade de atribuir ao trabalhador grande volume de trabalho, obrigando-o assim, para manter relativamente a produtividade, a trabalhar em jornada extraordinária, o mercado de trabalho encolhe o tempo de convivência social em outras esferas que não o emprego. Sabe-se que existem setores onde a jornada extraordinária é regra, e não exceção (desvirtuando, portanto, o sistema), daí porque a instituição de banco de horas (ou acordo de compensação), onde, teoricamente, o trabalhador estende a jornada em um dia e diminui em outro, compensando o tempo a mais trabalhado.

Ocorre que a forma legal em que banco de horas foi arquitetado muito mais atende às questões de gestão empresarial do que às boas condições de vivência do trabalhador, sendo muito mais uma flexibilização das normas trabalhistas do que regra de proteção, sendo certo que, como hoje está o instituto concretizado, é degradante.

Ademais, não apenas nas grandes cidades, mas também no ambiente rural, o tempo de deslocamento do trabalhador engole enormes lapsos diários, encurtando ainda mais o tempo de convivência do trabalhador. Este é um problema pouco enfrentado no Direito ${ }^{26}$, mas que traz enormes prejuízos à socialização do trabalhador, que acaba tendo a maior parte de seu tempo voltada apenas para o trabalho, sem qualquer equilíbrio com os outros aspectos importantes da vida.

Anote-se, por fim, outro fato a ser destacado nesta seara, que diz respeito à utilização de determinados equipamentos de proteção individual. Os EPIs têm, obviamente, função vital na proteção à saúde do trabalhador, e claro que o que aqui se defende não é o afastamento primário de sua utilização, mas os efeitos que estes equipamentos podem conferir à socialização do trabalhador. Por exemplo, a utilização de protetor auricular durante as oito horas diárias prestação de serviços. Esse trabalhador fica isolado durante esse lapso, sem contato com os outros trabalhadores, a não ser que pare de trabalhar e retire o equipamento, o que geraria dois problemas; o primeiro consiste na exposição ao agente degradante, ruído no caso; o segundo é a possibilidade de ser punido pela não utilização do equipamento; assim, o proletário passa toda sua vida laboral sem possibilidade de gozar no seu ambiente de trabalho da convivência social.

Diante dos exemplos aqui colacionados, é possível concluir-se que o trabalho que não permite ou não fomenta a socialização do ser humano por si é degradante.

\footnotetext{
${ }^{26}$ Com exceção, talvez, do direito urbanístico, que se volta aos ambientes urbanos, como sugere a nomenclatura.
} 


\subsubsection{5 "Dessubjetivização" do trabalhador}

A relação de emprego, no direito brasileiro, é formalizada através de um contrato. Um dos elementos essenciais ao contrato é a manifestação de vontade das partes, daí em se falar de autonomia da vontade. Para que o contrato seja considerado válido, se faz necessário que essa manifestação de vontade não seja viciada, conforme ensina Serpa Lopes (1996, p. 428): “a vontade é o elemento essencial do factum no negócio jurídico".

O estudo desta perspectiva no contrato de trabalho se faz indispensável na análise do que torna o labor degradante.

A expressão "autonomia da vontade" é encontrada em Kant (2005), precursor na utilização do termo. Segundo o filósofo "autonomia da vontade é aquela sua propriedade graças à qual ela é para si mesma a sua lei (independentemente da natureza dos objectos do querer)".

Se para Kant a vontade pode refletir uma autonomia que coincide com a liberdade, por não ter amarras com nenhum elemento exterior (Botton, 2005), por certo no contrato de trabalho dificilmente poder-se-á afirmar que a vontade do trabalhador se manifesta, já que no mais das vezes a aceitação que dá ao contrato de adesão - que já vem pronto e não depende de negociação de seus termos entre as partes - é pressionada por fatores concretos que o levam a efetivar o pacto laboral, ainda que não concorde com os termos ali expostos.

Orlando Gomes (1998, p. 266) conceitua autonomia como sendo "a esfera de liberdade da pessoa que lhe é reservada para o exercício dos direitos e a formação das relações jurídicas do seu interesse ou conveniência".

Ronaldo Lima dos Santos (2007, p. 102) aduz que o termo autonomia indica "a faculdade de determinada pessoa ou instituição para traçar normas de conduta sem imposições de qualquer ordem que lhe seja estranha; adquirindo, assim, o sentido de independência". No sentido amplo, continua o Autor, indica a "capacidade do sujeito de determinar seu próprio comportamento individual".

Vontade, para Santos, exprime a vontade do indivíduo de querer, e, juridicamente, é um elemento fundamental para o ato jurídico. (SANTOS, 2007) O Autor indica duas funções primordiais da vontade, a saber:

a) Singularizar o ser humano em relação aos seus iguais e, b) possibilitar ao ser humano, dotado de natural mobilidade, dar direcionamento em sua 
vida, segundo as inclinações resultantes de sua dinâmica existencial. (2007, p. 105)

Orlando Gomes (1998, p. 49) ainda indica que "a declaração de vontade há de ser emitida em correspondência ao conteúdo do contrato que o declarante tem em vista, atento ao fim que o move a contratar".

A vontade que move o trabalhador não é livre nem independente, pois a finalidade do contrato de trabalho é a obtenção de bens da vida para manter-se; ele não tem autonomia em relação à sua vontade, não deixa de sofrer influências quando anui ao contrato que formaliza a relação de emprego, porque depende do que aufere laborando para viver, fator que por si já coloca o Obreiro em situação de desigualdade com a outra parte do contrato, qual seja, o empregador. Por isso o trabalhador é tido como hipossuficiente frente aquele que detém poder econômico e político muito superiores.

E, observe-se, esta realidade independe do tipo de função exercida por ele, se é uma atividade braçal ou intelectual. $\mathrm{O}$ fato é que, necessitando do emprego para alcançar renda para viver, o trabalhador se sujeita a condições de contrato ruins não porque anui com elas, mas porque a outra opção na realidade não é factível, ou seja, sua escolha gira em torno de contratar um trabalho ainda que em condições degradantes ou ficar sem renda e sem a possibilidade de manter-se.

Tais considerações colidem com a idéia de autonomia da vontade no contrato de trabalho. Pode-se indicar como exemplo aquele trabalhador que autoriza cláusula que permite o desconto salarial quando causa prejuízo ao empregador por culpa; que empregado concordaria em ter descontado de seu salário um prejuízo que não quis causar ao trabalhador, devido a uma imperícia que foi motivada pelo próprio empregador, que deveria treinar seus empregados e não o faz?

Poderia ser suscitada a tese de que, se a imperícia foi gerada pelo empregador, afastaria a culpa, mas quem litigaria contra seu próprio empregador no curso do contrato, se não há garantia de emprego?

De fato, o empregado não tem realmente liberdade de contrato, autonomia da vontade, apenas adere ao contrato que lhe é imposto pelo empregador. O empregado é no mais das vezes subordinado não apenas juridicamente, mas economicamente ao empregador, e por esse motivo sua vontade é eivada de influências que o empurram para a aceitação do contrato. 
Consolidou-se a tese no Direito do Trabalho que de que o elemento caracterizador da relação de emprego é a subordinação jurídica, tendo em vista que nem todo empregado é necessariamente subordinado economicamente ao empregador. Teoricamente, esta afirmação é correta. Pode existir um trabalhador que tenha renda suficiente para sua manutenção para além do salário que recebe, mas essa situação é tão incomum que se pode afirmar sem medo de equívoco que, concretamente a maioria maciça dos trabalhadores é subordinada jurídica e economicamente. Não é outra a conclusão a que se pode chegar:

\begin{abstract}
A existência de trabalho escravo obriga o jurista a empreender renovada reflexão. As premissas contratuais clássicas que fundamentam parte do Direito do Trabalho devem ser revisitadas, pois nem sequer a liberdade fictícia do contrato de trabalho pode ser encontrada; a coação capitalista, ao invés de econômica e subreptícia, torna-se aberta e exibe sua face mais violenta. Como resultado, o combate efetivo não se dá pela repetição dos princípios e instituições clássicas, e exige o esforço inventivo e criativo dos juristas comprometidos em pôr fim ao trabalho escravo. (VELLOSO; FAVA, 2006, p. 13)
\end{abstract}

Por óbvio que a idéia não é o desmerecimento da importância dos princípios trabalhistas no combate ao trabalho degradante e na dignificação do trabalhador, mas sim que sua mera repetição não satisfaz estes objetivos, que se tornam efetivados na medida em que os princípios são concretizados nas relações de trabalho. E cabe aos exegetas do Direito do Trabalho, em especial aos julgadores, a efetivação dos princípios para que o trabalho não seja degradante.

Aduzir que a subordinação jurídica é a que caracteriza o contrato de emprego não concretiza a liberdade de contrato do trabalhado. Ricardo Marcelo Fonseca contribui com grande valia ao refletir:

O que difere a subordinação jurídica da subordinação pura e simples? A resposta é direta: os limites da atividade econômica do empregador, do risco físico e do atentado moral do empregado, e da prática de ato que seja ilícito. Afora a tais limites, a subordinação jurídica é idêntica à pura e simples subordinação. O que se deve compreender é que não foi o direito que inventou a relação de trabalho subordinado, e o requisito da subordinação jurídica, traçando depois a linha divisória do que seria o limite da subordinação jurídica e uma subordinação não jurídica. O que de fato ocorreu é que a subordinação do trabalhador já pré-existia à regulamentação do contrato de trabalho, e o direito positivo, 
confrontando-se com uma situação de subordinação já existente, traçou os limites formais para definir até onde essa subordinação poderia ser exercida licitamente (e denominou-a subordinação jurídica) (2001, p. 138)

É de se reconhecer, assim, que como regra a subordinação econômica é efetiva nos contratos de trabalho, não devendo o direito ignorar tal fato, atribuindo às partes uma condição de liberdade que não existe no caso dos trabalhadores.

No Direito Civil, há tendência doutrinária ${ }^{27}$ de superação da autonomia da vontade, por autonomia privada, e não se trata somente de preciosismo terminológico. Essa mudança reflete o reconhecimento de que a autonomia da vontade sofre com a real ocorrência de abusos na liberdade de contrato, que geram efeitos indesejáveis a ponto de se questionar a existência da livre manifestação. Como alude Otávio Luiz Rodrigues Júnior,

O império da autonomia privada na centúria que findou é inegável. Sob a escusa de afastar a superada visão de autonomia da vontade, permeada de insustentável individualismo, recorreu-se ao intervencionismo legal e judicial do Estado como forma de coibir os abusos da liberdade pelos particulares.(2004, p. 122)

Resta clara, assim, a pressão concreta que sofre o trabalhador em razão da manutenção de sua vida, não se podendo então afirmar que haja verdadeira manifestação de sua vontade no que alude ao contrato de trabalho, que deverá sofrer intervenção não penas do Estado, que limita a liberdade individual em prol do interesse público, mas também na necessária discussão acerca de outro elemento basilar no contrato, que é a parte ser reconhecida como sujeito de direito.

Como afirmou Fonseca, a subordinação do trabalhador é anterior à sua regulamentação (limitação) legal, e, mesmo com a limitação da autonomia da vontade limitada pela lei, o trabalhador, que teoricamente é sujeito de direito, continuou a ser sujeitado dentro da relação empregatícia, pois sobre ele é exercido toda forma de controle, "todo um mecanismo jurídico de medição e correção do comportamento do empregado" (2001, p. 167), mantendo-o atado a um sistema que na verdade o disciplina.

No caso do trabalhador, a liberdade formal é viciada pela necessidade concreta de obter um posto de trabalho e assim auferir renda para manutenção de sua vida.

\footnotetext{
${ }^{27}$ Vide Antônio Junqueira de Azevedo, Álvaro Villaça, dentre outros.
} 
Dentro do sistema capitalista, a progressão possível para tal dilema é a limitação do contrato de trabalho que reconheça a realidade opressora em que vive o trabalhador, para que, a partir do Direito Social, da inserção efetiva e eficaz de normas de Direitos Humanos e de interpretação constitucional e humanista, possa ser alcançada não apenas a igualdade formal, mas especialmente a igualdade material. 


\section{O TRABALHO DEGRADANTE COMO FATOR DE EXCLUSÃO SOCIAL}

\subsection{Exclusão social}

A exclusão social é um dos efeitos perversos causados pelo trabalho degradante. A partir desta hipótese de trabalho, inicia-se o estudo deste fenômeno, conceituando o termo, definindo seu significado e suas formas; segue então a pesquisa, sinalizando sobre o valor social do trabalho, para que se possa enfim, sob o caminho metodológico da análise de índices, dados e programas, indicar como o trabalho degradante exclui socialmente e quais impactos sociais advém desta realidade.

\subsubsection{Conceito}

O termo exclusão social surge na França ${ }^{28}$, em meados de 1960, pela necessidade de formulação de um fenômeno que a pobreza em si não abrangia, porque outros fatores geravam a exclusão, além da questão econômica. Tal conceito passou a ser difundido pela superveniência da crise econômica (1970), e, a partir de 1980, a exclusão social passou a agrupar em sua definição os diversos grupos que sofriam com a segregação social, não apenas os pobres, irradiando-se para toda Europa (Silver, 1994).

Conforme relata Zioni (2006, p. 15-29), para a esquerda, a noção de exclusão social trazida inicialmente pelos autores ${ }^{29}$, quando se referiam à exclusão, era para a indicação dos que eram inadaptados socialmente, como prostitutas, fugitivos, marginais, noção esta que se tornou alvo de grande crítica por parte daqueles primeiros, porque "era vista como

\footnotetext{
${ }^{28}$ A crítica que se faz a Escola de Sociologia Francesa na construção do conceito de exclusão social é que o termo, como é explicado por tal vertente, esconde a característica do capitalismo que é a dominação de classes, ou seja, a exclusão como fundamento do sistema capitalista. Ao retirar do trabalhador a fonte de seu sustento, ou seja, a terra, aproxima-o do trabalho subordinado e assalariado, salário este que por ser de pouco valor, retira-lhe a possibilidade de atingir os bens necessários à manutenção digna de sua vida. Daí emerge a idéia de que a exclusão é algo a ser corrigido pela inclusão, e não, algo interno e fundamental à subsistência do sistema. (Vide HARLOE, Michael. Marxismo, Estado e questão urbana. Espaço \& Debates. n. 28, p. 80100, 1989.)

${ }^{29}$ Cf., por exemplo, Les exclus: un français sur dix, de René Lenoir.
} 
uma manobra da classe dirigente para convencer a opinião pública sobre seus propósitos de reforma social, ao mesmo tempo em que evitava enfocar as verdadeiras causas da desigualdade social"; ademais, por assemelhar-se à noção de lúmpen-proletariat ${ }^{30}$, que, na concepção marxista, se referia àqueles que seriam incapazes de promover a revolução. Falar em exclusão significava afastar-se da visão dialética de luta de classes, aspecto esse que, nos anos 1970, teria impedido sua incorporação.

Assim, de acordo com a Autora, o termo "exclusão social" passou a ter uma conotação mais assemelhada a que hoje se conhece, e, consequentemente, a ter mais aceitação, inclusive pela esquerda, a partir do prolongamento da crise do petróleo e de seus efeitos, quando a idéia de inadaptação social foi cedendo espaço às questões acerca do desemprego como:

(...) problema central, pela consciência de que se estaria diante de um conjunto heterogêneo de situações instáveis, produtoras de novas dificuldades para grupos da população até o momento considerados ao abrigo da pobreza. Assim, a questão social passou a ser representada não mais como a situação de grupos marginais, incapazes ou inaptos para o progresso - conforme a representação das décadas precedentes -, mas como um risco para grupos da população perfeitamente adaptados à sociedade moderna, vitimados, porém, pela conjuntura econômica e pela crise do emprego. (ZIONI, 2006, p. 19-20)

Do surgimento e da consolidação da expressão exclusão social já se pode definir a importância e a correlação existente entre o universo do trabalho, do emprego e do desemprego com a segregação ou com a integração social.

A repercussão da expressão exclusão social pode ser sentida na medida em que a própria (então) Comunidade Européia passa a utilizar o termo em seus documentos oficiais, como se vê da resolução de 29 de setembro de 1989:

\footnotetext{
${ }^{30}$ Proletariado de trapos, ou seja, proletariado não integrado na força do trabalho, como os ladrões e as prostitutas, indivíduos que não desenvolveriam a consciência de classe. No capítulo V do seu "O 18 Brumário de Luís Bonaparte", Marx refere-se ao lúmpen-proletariat, como se pode verificar: "Nessas excursões, que o grande Moniteur oficial e os pequenos Moniteurs privados de Bonaparte tinham naturalmente que celebrar como triunfais, o presidente era constantemente acompanhado por elementos filiados à Sociedade de 10 de Dezembro. Essa sociedade originou-se em 1849. A pretexto de fundar uma sociedade beneficente o lúmpen-proletariado de Paris fora organizado em facções secretas, dirigidas por agentes bonapartistas e sob a chefia geral de um general bonapartista. Lado a lado com roués decadentes, de fortuna duvidosa e de origem duvidosa, lado a lado com arruinados e aventureiros rebentos da burguesia, havia vagabundos, soldados desligados do exército, presidiários libertos, forçados foragidos das galés, chantagistas, saltimbancos, lazzarani, punguistas, trapaceiros, jogadores, maquereaus(19), donos de bordéis, carregadores, líterati, tocadores de realejo, trapeiros, amoladores de facas, soldadores, mendigos - em suma, toda essa massa indefinida e desintegrada, atirada de ceca em meca, que os franceses chamam la bohêmne; com esses elementos afins Bonaparte formou o núcleo da Sociedade de 10 de Dezembro".
} 
RESOLUÇÃO DO CONSELHO E DOS MINISTROS DOS ASSUNTOS SOCIAIS, REUNIDOS NO SEIO DO CONSELHO de 29 de Setembro de 1989 relativa à luta contra a exclusão social (g.n.) (89/C 277/01) EL CONSEJO DE LAS COMUNIDADES EUROPEAS Y LOS MINISTROS DE ASUNTOS SOCIALES, REUNIDOS EN EL SENO DEL CONSEJO, 1. RECUERDAN los esfuerzos comunitarios, así como de los Estados miembros, ya realizados en el ámbito de la lucha contra la pobreza y a favor de la integración económica y social de los grupos de personas económica y socialmente menos favorecidos, que se materializan en particular en la adopción del tercer programa de lucha contra la pobreza (...) (UNIÃO EUROPÉIA, 1989)

Exclusão Social, segundo Giddens (2007, p. 265), diz "respeito às formas pelas quais os indivíduos podem acabar isolados, sem um envolvimento integral na sociedade mais ampla".

A partir desse preceito, pode-se afirmar que em uma mesma sociedade, existem os que estão a ela de certa maneira integrados (incluídos) e os que não estão integrados, aquelas pessoas segregadas do ambiente social (excluídos). A primeira noção que se pode tomar do termo exclusão social é a indicação de dualidade no agrupamento humano, como ensina Magdalena Jiménez Ramírez (2008, p.174):

La exclusión social está muy relacionada con los procesos que más se vinculan con la ciudadanía social, es decir, con aquellos derechos y libertades básicas de las personas que tienen que ver con su bienestar (trabajo, salud, educación, formación, vivienda, calidad de vida,...). Además, el concepto de exclusión social debemos entenderlo por oposición al concepto de integración social como referente alternativo, esto es, el vocablo exclusión social implica una cierta imagen dual de la sociedad, en la que existe un sector integrado y otro excluido. Así pues, el sector excluido se encuentra al margen de una serie de derechos laborales, educativos, culturales, etc., es decir, de una calidad de vida que se ha alcanzado y garantizado a través de los Estados de Bienestar ${ }^{31}$.

\footnotetext{
${ }^{31}$ A exclusão social está intimamente relacionada com os processos que mais se vinculam com a cidadania social, ou seja, com aqueles direitos e liberdades fundamentais das pessoas, que tem a ver com seu bem-estar (trabalho, saúde, educação, formação, moradia, qualidade da vida...). Além disso, o conceito de exclusão social deve ser entendido como oposição ao conceito de integração social como uma alternativa de referência, ou seja, o termo exclusão social implica uma certa imagem dual da sociedade, na qual existe um setor integrado e outro excluído. Assim, o setor excluído se encontra à margem de uma série de direitos trabalhistas, educacionais, culturais, etc, ou seja, de uma qualidade de vida que foi alcançada e garantida pelo Estado do Bem Estar Social. (tradução nossa)
} 
Giddens, seguindo a idéia de que exclusão social é termo que abrange muito mais do que a pobreza como fator de segregação, afirma que:

\begin{abstract}
Mais abrangente do que o conceito de classe baixa, tem ainda a vantagem de enfatizar os processos - mecanismos de exclusão. Por exemplo, pessoas que moram em um conjunto habitacional dilapidado, com escolas de baixa qualidade e poucas chances de emprego no local, podem não encontrar efetivamente as oportunidades de auto-aperfeiçoamento da maioria das pessoas na sociedade. Também é diferente da pobreza propriamente dita, concentrando sua atenção sobre uma ampla variedade de fatores que impedem que os indivíduos ou os grupos tenham as mesmas oportunidades que estão abertas para a maioria da população (2007, p. 265).
\end{abstract}

Nesse sentido, é de se valer da idéia que Hannah Arendt (1979, p. 223-224) traz sobre exclusão social. Para a referida Autora, excluídos são aquelas pessoas que não têm direito a ter direitos, como indica em seu livro As origens do totalitarismo:

A França - a maior área de concentração de imigrantes da Europa, pois controlava o caótico mercado de mão-de-obra ao apelar para trabalhadores estrangeiros em tempos de necessidade e deportando-os em tempos de desemprego e de crise - ensinou aos 'seus' estrangeiros uma lição sobre as vantagens da condição do apátrida que eles não iriam esquecer facilmente. (...) Muito pior que o dano causado pela condição do apátrida às antigas e necessárias distinções entre nacionais e estrangeiros e ao direito soberano dos Estados em questões de nacionalidade e expulsão, foi aquele sofrido pela própria estrutura das instituições legais da nação, quando um crescente número de residentes teve de viver fora da jurisdição dessas leis, sem ser protegido por quaisquer outras. $\mathrm{O}$ apátrida, sem direito à residência e sem direito de trabalhar, tinha, naturalmente, de viver em constante transgressão à lei. Estava sujeito a ir para a cadeia sem jamais cometer um crime. Mais do que isso, toda a hierarquia de valores existente nos países civilizados era invertida no seu caso. Uma vez que ele constituía a anomalia não prevista na lei geral, era melhor que se convertesse na anomalia que ela previa: o criminoso. A melhor forma de determinar se uma pessoa foi expulsa do âmbito da lei é perguntar se, para ela, seria melhor cometer um crime. Se um pequeno furto pode melhorar a sua posição legal, pelo menos temporariamente, podemos estar certos de que foi destituída dos direitos humanos. (...) Só como transgressor da Lei pode o apátrida ser protegido pela lei. Enquanto durem o julgamento e o pronunciamento da sua sentença, estará a salvo daquele Domínio arbitrário da polícia, contra o qual não existem advogados nem apelações. O mesmo homem que ontem estava na prisão devido à sua mera presença no mundo, que não tinha quaisquer direitos e vivia sob ameaça de deportação, ou era enviado sem sentença e sem julgamento para algum tipo de internação por haver tentado trabalhar e 
ganhar a vida, pode tornar-se quase um cidadão completo graças a um pequeno roubo.

Essa realidade exposta por Arendt pode ser retratada pela situação dos bolivianos, coreanos e chineses que, sendo introduzidos no país para atuar como mão-de-obra de determinados setores legais e ilegais (confecção, cópias ilegais de CDs e DVDs, etc.), que vivenciam a exclusão de direitos, pois só passam efetivamente a possuir determinadas garantias legais (alimentação, saúde, etc.) quando inseridos no sistema prisional; enquanto trabalhadores de uma sociedade que usufrui de sua força de trabalho mas não o reconhece, é excluído de quase qualquer benefício social, por mínimo que seja, passando a ter reconhecimento somente quando descobertos ou quando presos.

Silver (1994) aponta três paradigmas, ou três parâmetros em relação à exclusão social, a saber: a solidariedade, a especialização e o monopólio. Em relação à solidariedade, pode-se afirmar, segundo a Autora, que a coesão moral entre os indivíduos é resultado da integração, e, ao contrário, a exclusão é resultado da decadência de valores sociais; em relação à especialização, a integração se dá pela troca, e a exclusão pela falha no processo de diferenciação e interdependência entre diferentes esferas sociais, dificultando assim a circulação entre elas; em relação aos excluídos por não serem considerados cidadãos, segregação chamada pela Autora de monopólio, a integração se faz a partir da extensão dos direitos de cidadania, e a exclusão pela delimitação de fronteiras e do empoderamento de determinados grupos sociais (em detrimento de outros).

Weffort (1992, p. 23-25) registra que, na democracia brasileira, não há a integração de sequer metade de sua população; que tal fato constitui um sistema dual de dominação, haja vista que "para os indivíduos que estão integrados, existem mecanismos efetivos de participação e influência, ao passo que para os que ficam de fora há um regime de coerção e, em casos extremos, de terror", indicando assim outra perspectiva da exclusão social. Esse sistema dual é identificado não só pela exclusão econômica de parte da população, mas também da exclusão política e social, haja vista que, mesmo que a Constituição de 1988 tenha trazido em seu bojo uma série de direitos estendidos a todos, é certo que:

Párias numa sociedade, teoricamente, sem castas, sequer conhecem "seu direito a ter direitos" e quando o simples sobreviver é uma tarefa tão difícil, é quase impossível esperar-se uma forma de organização, mobilização, participação e pressão por mudanças que os "promovam" a cidadãos de primeira classe. Assim, não existe o mínimo vital definido por Arendt para que possam emergir no espaço público, o que fazem, 
quando o fazem, através de explosões e violência. (ESCOREL, 1993, P. 47)

Exclusão social, portanto, é um conceito que inicialmente designava os inadaptados sociais, e, posteriormente, se consolidou na representação dos indivíduos ou que não possuem qualquer tipo de direitos por não serem considerados cidadãos, ou aqueles que, ainda que cidadãos e portadores de direitos, não os têm consolidados no meio social, notadamente porque, não sendo integrado economicamente à sociedade (especialmente por meio do emprego, na análise aqui firmada, e daí se revela a importância da ligação entre trabalho e exclusão), também não se integra política e socialmente, sendo estas as três principais formas de exclusão, conforme se identificará a seguir.

\subsubsection{Formas}

São diversas as formas de exclusão que podem ser encontradas no ambiente social. Pode-se identificar a exclusão: pelo nível do grupo social (minorias étnicas, minorias religiosas), como no caso dos indígenas, dos negros, daqueles que professam sua fé guardando o sábado (judeus, adventistas do sétimo dia); pelo gênero, como no caso das mulheres; pela idade, como no caso das crianças, dos jovens e dos idosos; pela opção sexual, como no caso dos homossexuais, bissexuais e transexuais; pela diferença dos padrões adotados socialmente, como no caso dos deficientes físicos - cegos, obesos, surdos, mutilados, dos doentes em geral etc.; excluídos do trabalho, como no caso dos desempregados, estejam eles na seara do desemprego temporário ou do desemprego de longo prazo, terceirizados, subempregados, etc.; pelas questões sócio-culturais, como no caso dos moradores da periferia dos centros urbanos.

$\mathrm{Na}$ realidade, são inúmeras e infinitas as formas pelas quais as pessoas são excluídas, dependendo, para seu reconhecimento, da identificação não apenas da vítima da exclusão, mas também do grupo que exclui e da especificação do contexto onde ela se verifica. Daí porque se torna tarefa inglória identificar todas as formas de exclusão.

Assim, urge reconhecer que a idéia pré-concebida de que a exclusão advém necessariamente da pobreza não se concretiza. Galbraith $(1979$, p. 26) aduz que o fim da 
injustiça não é necessariamente, nem costuma ser, o fim da pobreza. As formas que a exclusão toma justificam tal idéia; pode-se ilustrar essa realidade ao pensar na exclusão social, por idade, por opção sexual, por gênero, dentre outras situações em que a condição econômica não influencia na segregação.

Para que a questão da exclusão possa ser melhor reconhecida, optou-se pela classificação criada por Giddens (2007, p. 265), que, sendo mais abrangente, abarca as mais diversas formas de segregação social.

Pode-se indicar três formas básicas de exclusão, a saber: exclusão econômica, exclusão política e exclusão social (GIDDENS, 2007, p. 265). São modos distintos de privação, que doravante serão apontadas e comentadas, ressaltando-se, no entanto, que essas formas não são estáticas, certamente amalgamam-se e imiscuem-se na dinâmica social.

Giddens (2007) aduz que, na exclusão econômica, indivíduos e comunidades podem ser extirpados da economia no que diz respeito à produção e ao consumo. Quanto ao aspecto da produção, o emprego e a participação no mercado de trabalho são itens centrais, pois sem eles os indivíduos dificilmente são incluídos na seara social. Em comunidades que apresentem altas concentrações de privação material, é menor o número de pessoas que trabalham em tempo integral, e as redes informais de informações, capazes de auxiliar os desempregados a ingressarem no mercado de trabalho, são ineficientes. As taxas de desemprego são, com frequência, altas, e as oportunidades ocupacionais são, de modo geral, limitadas. Uma vez excluídas do mercado de trabalho, as pessoas podem achar seu reingresso extremamente difícil.

A exclusão da economia também pode se dar em termos de padrões de consumo, ou seja, com relação ao que as pessoas adquirem, consomem e utilizam em sua vida diária. A falta de um telefone pode contribuir para a exclusão social - o telefone representa um dos principais pontos de contato entre os indivíduos e o mundo mais amplo dos amigos, da família, dos vizinhos e dos membros da comunidade. Não possuir uma conta bancária é outro sinal de exclusão, já que as pessoas não conseguem aproveitar os diversos serviços oferecidos pelos bancos aos seus clientes. Notadamente, a principal forma de consumo da população mais carente se dá pelo parcelamento do valor principal da compra, e, para tanto, é necessária a comprovação de crédito na praça, que, no mais das vezes, ocorre pela confirmação da existência de conta bancária. 
A exclusão econômica é facilmente identificada, no ambiente urbano em especial, pela falta ou precariedade de moradia, pelo desemprego ou subemprego e falta de acesso a serviços vitais, como na área de saúde (DUPAS, 1998)

A falta de moradia é um dos exemplos mais críticos de exclusão social. As pessoas que não dispõem de uma residência permanente descobrem ser praticamente impossível participar em condições de igualdade da sociedade. Para os estudiosos do espaço urbano e das questões, portanto, de urbanística, incluindo-se aí o direito urbanístico, a regularização de espaços habitacionais de população de baixa renda, como favelas e loteamentos precários é passo fundamental para o enfrentamento da questão da moradia, pois atinge o indivíduo nas questões objetivas, de ter efetivamente uma residência, e nas questões satélites, como ter um endereço com identificação de Rua, CEP (código de endereçamento postal), para indicar, por exemplo, em uma entrevista de emprego, o que diminui a discriminação, na medida em que deixam de ser reconhecidos pejorativamente como "favelados" (GASPAR, AKERMAN E GARIBE, 2006, p. 179 et seq.).

Giddens (2007) identifica uma segunda forma de exclusão, a política. A participação popular e contínua na política é o alicerce dos Estados democráticos liberais. Os cidadãos são estimulados a manterem uma atitude consciente quanto às questões políticas, a levantarem sua voz em apoio ou em protesto, a contatarem seus representantes eleitos para assuntos importantes, e a participarem do processo político em todos os níveis. Isso significa dizer que não é apenas por meio do sufrágio universal que se encerra a participação política das pessoas, mas também através de outros expedientes.

Porém, uma participação política ativa pode estar fora do alcance dos indivíduos socialmente excluídos, a quem podem faltar as informações, as oportunidades e os recursos necessários para o envolvimento no processo político. A título de exemplo, imagine-se um indivíduo que está desempregado por longo prazo. Não conta mais com o segurodesemprego, que é temporalmente limitado, nem mesmo com a possibilidade de usufruir gratuitamente do transporte público, benefício que também já se expirou. Sente-se fora da sociedade para direitos básicos e imediatos, que dirá para o exercício da cidadania, que é básico, mas não é necessariamente imediato, e nem reconhecido como tal pela maioria da população. Esse indivíduo não dispõe nem de meios financeiros nem de vontade para participar da política, e, ainda, nem mesmo tem acesso às informações mínimas para entender o grau de importância da política na dimensão objetiva da vida.

Giddens afirma que fazer "lobby, participar de comícios e comparecer a reuniões políticas, tudo isso exige um grau de mobilidade, tempo e acesso à informações que podem 
estar faltando em comunidades excluídas"; continua aduzindo que "tais desafios crescem em espiral, à medida que as vozes e as necessidades dos socialmente excluídos não conseguem ser incorporados às agendas políticas" (2007, p. 265).

No Brasil, com o processo de redemocratização surgido após a ruptura com o regime militar (ditador e antidemocrático), emergiram novas oportunidades de participação na vida política, como o próprio sufrágio universal, que se universalizou para todas as esferas de poder. A participação popular no processo político corresponderia à oportunidade dos representados se fazerem ouvir nas questões de interesse comum, manifestando assim críticas e opiniões, bem como auxiliar na concretização das ações públicas e na fiscalização dos órgãos públicos. Conforme aludem Maricato e Santos Jr. (2006, p. 1-2):

\begin{abstract}
A participação da sociedade civil por meio da representação de interesses diversos tem o papel de garantir, em primeiro lugar a inclusão, no debate democrático, daqueles que estiveram historicamente alijados das discussões sobre os rumos do país e em segundo lugar fazer aflorar os conflitos de interesses e dar a eles um tratamento democrático o que é inédito em nossa sociedade, na escala considerada. Não se trata de ignorar, ingenuamente, o papel da luta de classes, que ganha contornos dramáticos, no capitalismo global. Nem se desconhece a sobrevivência da tradicional e cultural manipulação do aparelho do Estado como coisa privada e pessoal no Brasil. Mas trata-se de dar visibilidade aos conflitos, sempre ocultados pela tradição do "homem cordial" e construir novos paradigmas de consciência e organização social que contrariem o patrimonialismo na condução do Estado.
\end{abstract}

Uma organização social que cada vez mais tem sido desvirtuada e enfraquecida, o Sindicato, poderia ter um papel central, se revitalizado e se efetivamente tivesse força representativa na seara da participação política, como órgão que expressa a força e a voz da classe trabalhadora. Ademais, teria também a importante função de informar os trabalhadores, elevando e aprimorando sua capacidade de participação na vida pública.

Por fim, Giddens (2007, p. 265-266) indica como terceira possibilidade de exclusão, a segregação social. Por óbvio que toda exclusão, de maneira abrangente, é social, mas a referência aqui realizada gira em torno da dimensão mais estrita do termo, porque pode ser sentida no domínio da vida diuturna comunitária. O referido Autor indica a título de ilustração, que áreas que sofram de alto grau de exclusão social podem contar com instalações comunitárias limitadas, como parques, quadras de esportes, centros 
culturais e teatros. Note-se que tais instalações podem ser os espaços públicos necessários naquela comunidade para a discussão da vida em comum.

Os níveis de participação na vida social são muitas vezes baixos; ademais, “famílias e indivíduos excluídos podem ter menos oportunidades de lazer, viagens e atividades fora de casa. A exclusão social também pode significar uma rede social limitada ou frágil, que leva ao isolamento e a um contato mínimo com os outros" (p. 266).

Giddens (2007) traz uma afirmação que para o universo do trabalho é esclarecedora. Diz o sociólogo que o conceito de exclusão social levanta a questão da ação; “afinal, a palavra "exclusão" implica que alguém ou algo está sendo alijado por outro. Certamente, há casos nos quais os indivíduos são excluídos através de decisões que estejam fora de seu próprio controle"; indica como exemplos de tal afirmação que "os bancos podem se recusar a conceder uma conta corrente ou cartões de crédito a indivíduos que morem em determinada área de código postal", e que "as companhias de seguro podem rejeitar um pedido de apólice com base na história pessoal e na origem do requerente". Mas o exemplo mais representativo colacionado pelo Autor, no que tange ao tema apresentado, está no universo do trabalho: "Um empregado que teria sido dispensado por excesso de pessoal, quando já estava com uma certa idade, pode deixar de conseguir emprego por não ser mais jovem". O que significa dizer que, independentemente da vontade do trabalhador, se não há um poder maior (o Estado) determinando que este trabalhador não pode ser discriminado, e que realize políticas públicas de inclusão, este indivíduo, não por sua culpa ou vontade, é afastado do mercado de trabalho, ilustração que induz à descrença na ultrapassada teoria da auto-regulação do mercado.

A exclusão social, continua o teórico, não é apenas resultado de pessoas sendo excluídas, podendo ainda resultar da atitude de pessoas que resolvem se excluir de aspectos da sociedade dominante:

Os indivíduos podem optar por desligarem-se da educação, recusarem uma oportunidade de emprego e tornarem-se economicamente inativos, ou ainda por se absterem de votar em eleições políticas. Ao considerar o fenômeno da exclusão social, mais uma vez, é preciso que tenhamos consciência, por um lado, da interação que há entre a ação e responsabilidade humana, e, por outro, do papel das forças sociais que moldam as circunstâncias para as pessoas. $(2007$, p. 266) 
É claro que aqui não se pretende induzir que o indivíduo tem a força suficiente, com liberdade e igualdade, de fazer suas escolhas sem qualquer influência, mas sim reconhecer que a exclusão não se dá apenas por força direta de quem exclui, mas pode ser gerada pelo sentimento de baixa estima e culpa de quem é excluído com base nos padrões sociais estabelecidos.

Por exemplo, não é incomum que pessoas que exerciam outras profissões mais reconhecidas socialmente, se inibam de ter em sua CTPS anotação de relação de emprego doméstico. A justificativa-padrão é que uma anotação de doméstica na cateira de trabalho "mancharia" seu histórico profissional e dificultaria a inserção no mercado comum; daí porque muitas pessoas que encontram vaga de trabalho no ambiente doméstico pleiteiam a não anotação da CTPS com a função de empregada doméstica, preferindo ${ }^{32}$ ficar no mercado informal de trabalho a ter anotação como doméstica.

Como restará indicado pelos dados e estatísticas colhidos no decorrer do capítulo, há uma estreita ligação entre criminalidade e exclusão. Para Elliott Currie:

\begin{abstract}
A sociedade americana é um laboratório natural, tendo em vista que fomenta e aplica a política social voltada para o mercado, e que a "face ameaçadora" dessa realidade pode ser ilustrada pelo aumento da pobreza e do número de sem tetos, uso abusivo de drogas e elevação brusca dos crimes violentos; que os jovens crescem sem o devido amparo dos adultos, e, paradoxalmente, o mesmo mercado que os rejeita nas oportunidades de trabalho, exercem sobre eles enorme sedução para o consumo, o que pode resultar em um sentimento de privação que os dispõem a aceitarem formas ilícitas de obtenção desses produtos, porque são motivados pelo desejo do pertencimento pelo consumo. (apud GIDDENS, 2007, p. 271 et. seq.)
\end{abstract}

Currie ainda indica como elos importantes de conexão entre criminalidade e exclusão social, dentre eles, forma de tributação do governo, e, ainda mais relevantes para o vertente trabalho, políticas de salário mínimo e mudanças no mercado de trabalho, todos eles motivadores para os índices de criminalidade.

A negação do direito à cidade se expressa na irregularidade fundiária, no déficit habitacional e na habitação inadequada, na precariedade e deficiência do saneamento ambiental, na baixa mobilidade e qualidade do transporte coletivo e na degradação ambiental. Paralelamente, as camadas mais ricas continuam

\footnotetext{
${ }^{32}$ Preferindo aqui não significa exatamente uma escolha livre, mas sim pressionada pelas tendências sociais.
} 
acumulando cada vez mais e podem usufruir um padrão de consumo de luxo exagerado. É no contexto dessa contradição expressa na segregação urbana que explode a violência e cresce o poder do crime organizado na cidade. Os paradigmas hegemônicos do urbanismo e do planejamento urbano têm revelado seus limites e não estão conseguindo dar respostas aos problemas contemporâneos das grandes cidades (MARICATO, SANTOS JR., 2006, p. 3):

Não é outra a conclusão a que chegam Ermínia Maricato e Orlando Santos

Jr., quando indica que a exclusão, ali representada pela falta de moradia regular, pelas más condições de saneamento, transporte, etc., fatores que certamente não são exaustivos, pois seguem unidos à questão da falta de trabalho e do subemprego, elementos que são extremamente impactantes na questão do crescimento da violência, porque representam a exclusão social dos indivíduos. O trabalho degradante, como um fator determinante na questão da exclusão, será melhor desenhado a seguir.

\subsection{O trabalho degradante como fator de exclusão social}

\subsubsection{O valor social do trabalho}

O trabalho surge juntamente com o homem. Desde o início dos tempos, o ser humano não sobrevive a não ser do resultado do trabalho. Para se proteger das intempéries da natureza, da vida rústica, para obter alimento, etc., o homem depende do trabalho, seu ou de outrem. A forma como se dá esse trabalho, e a forma como o trabalho de um é aproveitado por outro, porém, sofreu transformações na linha da história, modificando inclusive o valor atribuído socialmente ao labor, e são essas modificações e significados que serão doravante estudados.

De acordo com o Dicionário de Filosofia (BARRETO, 2006, p. 829 a 833), ao termo trabalho pode ser atribuído inúmeros significados no decorrer da história humana, que passarão a serem descritos. 
O termo tem origem latina, advindo da palavra tripalium, que era "uma armação de três estacas utilizada nas fazendas para ajudar nos partos e nas ferragens dos animais, que, no início da idade média, porquanto vinculada ao sofrimento e a dor, é percebida como um instrumento de suplício". De acordo com a etimologia, tal termo se imiscui à palavra trabicula, que é "uma pequena viga designando um cavalete de tortura, e assim produzir a noção de que trabalhar consiste em fazer sofrer". Assim, antigamente, trabalho designa "as duras penas e a miséria da vida". Apenas posteriormente, muitos anos depois, que o termo traduz a idéia de "canalização de esforços para a superação das dificuldades. Portanto, trabalho passa a ter um significado enobrecedor,

(...) evidenciando uma transformação de sentido que emprestará ao trabalho uma utilidade, isto é, um valor de uso que irá forjar, por sua vez, o alcance quase anódino que atualmente se empresta ao termo. Embora seu significado tenha se modificado ao longo do tempo, sua perenidade conduz à indagação se o homem e a história incluem, de forma ontológica, o trabalho. (BARRETO, 2006, p. 829 a 833)

Trabalho, no sentido como hoje é reconhecido, é um termo cunhado na modernidade, o que significa dizer que não pode ser entendido da mesma maneira durante toda a história humana, pois, como já afirmado, encerra uma diversidade de significados. As atividades que modernamente seriam entendidas como um "conjunto unificado das condutas de trabalho", na antiguidade clássica teria outra concepção.

Entre os gregos, o trabalho apresenta um plexo de noções. Existe um termo para "designar o esforço, a atividade penosa, um grupo de palavras distintas permite nomear as diversas tarefas"; existe também outra palavra para designação do "saber especializado". Assim, trabalho é um termo que abrange outras concepções no mundo antigo, sem exato correspondente, sendo certo que a divisão do trabalho só seria aplicada à antiguidade com reservas, tendo em vista que "a divisão de tarefas não é ali sentida como uma necessidade vinculada à maximização da atividade produtiva".

Hanna Arendt (2000), no seu A condição humana, usa o termo vita activa ${ }^{33}$ (vida humana na medida em que se empenha ativamente em fazer algo), que indica três

\footnotetext{
33 Neste sentido, vita activa se diferencia de vida contemplativa, já que a primeira respeita às atividades físicas humanas, e a segunda às atividades do pensamento humano.
} 
atividades distintas, a saber: trabalho, labor e ação. Apesar da aparência de similitude, são termos bastante diferentes:

Labor é a atividade que corresponde ao processo biológico do corpo humano, cujos crescimento espontâneo, metabolismo e eventual declínio têm a ver com as necessidades vitais produzidas e introduzidas pelo labor no processo da vida. A condição humana do labor é a própria vida. (ARENDT, 2000, p. 15)

A autora traz também a definição de trabalho, indicando seu sentido de transformação do mundo natural para um mundo fabricado:

O trabalho é a atividade correspondente ao artificialismo da existência humana, existência esta não necessariamente contida no eterno ciclo vital da espécie, e cuja mortalidade não é compensada por este último. $\mathrm{O}$ trabalho produz um mundo 'artificial' de coisas, nitidamente diferente de qualquer ambiente natural. Dentro de suas fronteiras habita cada vida individual, embora este mundo se destine a sobreviver e a transcender todas as vidas individuais. A condição humana do trabalho e a mundanidade. (ARENDT, 2000, p. 15)

Para completar o sentido da expressão vita activa, a autora traz ainda a definição de ação, contemplando assim as três atividades que considera fundamentais ao homem:

A ação, única atividade que se exerce diretamente entre os homens sem a mediação das coisas ou da matéria, corresponde à condição humana da pluralidade, ao fato de que os homens, e não o Homem, vivem na terra e habitam o mundo. Todos os aspectos da relação humana têm alguma relação com a política; mas esta pluralidade é especificamente a condição - não apenas a conditio sine qua non, mas a conditio per quan - de toda vida política. Assim, o idioma dos romanos - talvez o povo mais político que conhecemos - empregava como sinônimas as expressões 'viver' e 'estar entre os homens' (inter homines esse), ou 'morrer' e 'deixar de estar entre os homens' (inter homines esse desinere). (...) A pluralidade é a condição da ação humana pelo fato de sermos todos os mesmos, isto é, humanos, sem que ninguém seja exatamente igual a qualquer pessoa que tenha existido, exista ou venha a existir. (ARENDT, 2000, p. 15-16)

Os homens são seres condicionados, sendo que "tudo aquilo com o qual eles entram em contato torna-se imediatamente uma condição de sua existência"; o mundo onde ocorre 
a vita activa é formado pela produção humana, através de suas atividades, e de forma continua as coisas "que devem sua existência exclusivamente" ao homem também o condicionam. Partindo do que encontram no ambiente natural, os homens criam suas coisas, e estas criações o condicionam tanto quanto as coisas naturais. "O que quer que toque a vida humana ou entre em duradoura relação com ela, assume imediatamente o caráter de condição da existência humana". Daí porque os homens são sempre seres condicionados, porque a existência humana seria impossível sem estas coisas, e estas seriam um "amontoado de artigos incoerentes" se não fossem "condicionantes da existência humana" (p. 17).

Modernamente, labor e trabalho são palavras utilizadas como sinônimos, mas observando a evolução dos termos, Hanna identifica que a palavra labor, utilizada como substantivo, não designa o produto final, "o resultado da ação de laborar; permanece como substantivo verbal, uma espécie de gerúndio", ou seja, não designa a ação. Da palavra correspondente a trabalho, por sua vez, deriva o nome próprio do produto (o resultado da ação), mesmo nos casos em que a forma verbal da palavra "se tornou praticamente obsoleta".

Analisando a origem das palavras que resultam no que modernamente se entende por trabalho e labor, no sentido de tentar estabelecer distinções entre ambas, a autora identifica entre os gregos, que na medida em que o labor indicasse um esforço que não apresentasse um resultado que fosse positivamente valorizado em âmbito social (como exemplifica a autora, um monumento, uma obra de grande porte, que deixe vestígio), era desprestigiado. Se antes existiam os "escravos e os operários do povo em geral", os primeiros perdedores na guerra, que trabalhavam e conviviam no ambiente doméstico, "provendo o próprio sustento e o de seus senhores", e os segundos com "liberdade de movimento fora da esfera privada e dentro da esfera pública; apenas no final do século $\mathrm{V}$ que surge a valoração do trabalho pelo a quantidade de esforço que exigem. Podendo-se indicar mesmo que o labor braçal, que advém do movimento de nosso corpo, sugere uma ação servil.

Assim, qualquer atividade que empreendesse suprir as necessidades vitais, eram valoradas como labor e assim, desdenhadas, e tal fato justificou a opção grega de defesa da escravidão, porque, se tais necessidades eram vitais, deveriam ser realizadas, mas não pelos cidadãos livres. Assim, o labor era excluído do cotidiano dessas pessoas, que, 
subjugando outros seres humanos, obtinham os bens da vida sem ter de se debruçar sobre o labor, atividade servil que era, assim, destinada aos escravos.

Labor, nessa toada, simboliza a "escravização pela necessidade, escravidão esta inerente às condições da vida humana" (ARENDT, 2000, 94), o que significa dizer que, para ser livre, o homem deveria se abster do labor, e, isso somente era possível a partir da escravização de outra pessoa. Diferentemente da escravidão moderna, na antiguidade este instituto não tinha a conotação de obtenção de mão-de-obra gratuita nem de exploração para fins de acumulação de lucro, mas sim excluir da vida dos homens (livres) o labor.

A distinção existente entre labor na vida privada (desvalorizado) e na vida pública (valorizado) passa a ser amortecido, porque até a contemplação, como ocupação política, passa a ser vista como necessidade, com a teoria política advinda dos filósofos gregos, e a necessidade, assim, ocupa a posição de "denominador comum" de todas as atividades da vita activa.

O pensamento cristão, nesse aspecto, pouco ou nada alterou esta situação, pois com ele o trabalho passa a ser considerado algo glorioso e positivo, como se verá a seguir.

De acordo com o Dicionário de Filosofia, "na modernidade, com a construção de um conteúdo quase singular para o trabalho, a troca torna-se econômica”. A ética, assim, ganha novo contorno: "ela não mais serve para construir um ethos comum, tal qual concebida na Grécia Antiga, mas para combater e regular a concorrência, para estabelecer os limites da troca" (2006, p. 830).

No contexto da reconstrução do significado do trabalho, ele se transforma no "único registro de organização social". Conforme indica Roberto Fragale Filho (BARRETO, 2006), é o aparecimento do "trabalho abstrato, dotado de um valor econômico, que irá reestruturar a lógica das trocas, doravante centrada na economia". Continua o autor afirmando que a sociologia, então, estrutura seu objeto de estudos, qual seja, a sociedade, sempre a partir do trabalho, "fixando seus elementos explicativos nas relações sociais de produção (Karl Marx), na divisão social do trabalho (Émile Durkheim) ou na racionalidade (Max Weber)", recusando outras possibilidades de entendimento sobre o trabalho e a vida. Alude ainda que "restaram prejudicadas as relações explicativas que poderiam ser construídas a partir de um diálogo estabelecido entre trabalho e culto, jogo, lazer ou disciplina". 
Em relação ao trabalho sob a ótica do culto, poderia se estabelecer que o labor seria uma forma de flagelo necessário para a expiação da culpa, como se pode observar da máxima beneditina ora et labora:

\begin{abstract}
Nos mosteiros beneditinos de toda a Europa medieval, os monges eram arrancados ao minguado conforto dos seus colchões de palha e ásperos cobertores pelos sineiros, que os despertavam às 2 horas da madrugada. Momentos depois, dirigiam-se apressadamente, ao longo dos frios corredores de pedra, para o primeiro dos seis serviços diários na enorme igreja (havia uma em cada mosteiro), cujo altar, esplendoroso na sua ornamentação de ouro e prata, resplandecia à luz de centenas de velas. Esperava-os um dia igual a todos os outros, com uma rotina invariável de quatro horas de serviços religiosos, outras quatro de meditação individual e seis de trabalhos braçais nos campos ou nas oficinas. As horas de oração e de trabalho eram entremeadas com períodos de meditação; os monges deitavam-se geralmente pelas 6.30 horas da tarde. Durante o Verão era-lhes servida apenas uma refeição diária, sem carne; no Inverno, havia uma segunda refeição para os ajudar a resistir ao frio. (...) Em todos os antigos mosteiros beneditinos, a vida era totalmente comunitária. A rotina diária centrava-se naquilo a que S. Bento chamava "trabalho de Deus" - demorados ofícios de complexidade crescente. Tudo o resto era secundário. $\mathrm{O}$ trabalho manual que a regra estipulava existia não só para fornecer aos frades alimentação e vestuário e satisfazer-lhes outras necessidades, como também para evitar a sua ociosidade e lhes alimentar a alma mediante a disciplina do corpo. Posteriormente, quando as abadias enriqueceram, sobretudo através de doações de fiéis devotos, os dormitórios comunitários foram substituídos por celas individuais; e foram contratados trabalhadores para cuidarem dos campos, o que permitiu a muitos monges dedicarem-se a outras actividades, nomeadamente o estudo, graças ao qual a Ordem de S. Bento viria a ser tão justamente célebre. (UNIVERSIDADE DE LISBOA, 2010)
\end{abstract}

No entanto, não se pode deixar de reconhecer que, em certo sentido, o trabalho passa então a carregar um significado menos trágico. O conceito de trabalho se modifica com São Bento, também conhecido como São Benedito, quando afirma, ao se referir ao trabalho diuturno, que:

ociosidade é inimiga da alma; por isso, em certas horas devem ocupar-se os irmãos com o trabalho manual, e em outras horas com a leitura espiritual", retirando, assim, do trabalho, a conotação pejorativa que indicava a condição inferior de seu executor, e passa, a partir de então, a ser necessário contra os malefícios do ócio, em consonância com o dito popular, que certamente tem 
origem nesse pensamento beneditino, de que "mente vazia é oficina do diabo" (MOSTEIRO..., 2010)

A ótica beneditina acerca do trabalho marcou fortemente a compreensão que se arrasta até hoje acerca do termo. Mais adiante na história, a idéia sobre o trabalho continua na esteira da transformação, especialmente com o advento da revolução francesa e, posteriormente, da revolução industrial, que marcará fortemente a concepção que se tem modernamente sobre o tema.

Parte da doutrina ${ }^{34}$ estabelece a Revolta dos Iguais como movimento de preleção da Revolução Industrial. Este movimento histórico começa a ser escrito por Gracchus Babeuf, como ensina Trindade (2002), jovem estudioso que defendia a propriedade em comum, e no seu manifesto dos plebeus, de 1796, aduz que a democracia é” a obrigação dos que têm demais de servir os que não têm o bastante", concluindo que os que têm demais alcançaram esta condição roubando dos que têm de menos, e que seria justo a retomada desse excedente, além de que a solução para tal impasse estaria na criação de uma administração comum, comunitária. Babeuf teve sua ordem de prisão decretada, e o então jovem general Bonaparte, comandou o fechamento do clube político Panthéon, mas Babeuf conseguiu fugir.

Com a dificuldade de organizar movimentos sociais, que, além de duramente reprimidos não mais se desenvolviam com agilidade e agrupamento pela propaganda revolucionária, a saída foi circular nos bairros operários um outro manifesto, conhecido como manifesto dos iguais, mas essa ação não obteve êxito e seu líder acabou sendo executado em 1797. No entanto, esse movimento marcou a história pela conotação socialista de que era imbuída.

Na restauração européia, que teve seu apogeu com a queda de Napoleão na França, em 1815, iniciou-se um período de 15 anos marcados pela opressão e pela volta da monarquia, especialmente na Rússia, França, Prússia e Áustria, não mais identificada pelo feudalismo, já que o liberalismo havia fincado definitivamente suas raízes na estrutura socioeconômica desses países, e os trabalhadores se viam longe dos ideais da Revolução Francesa e massacrados pela indignidade, em trabalhos, jornadas e condições subumanas.

A Inglaterra, então, já havia se transformado em grande potência comercial. Com o advento da "fiandeira e do tear mecânicos, produção de ferro com carvão de coque e

\footnotetext{
${ }^{34}$ Vide José Damião da Lima Trindade, História dos Direitos Humanos, 2. ed. São Paulo: Peirópolis, 2002.
} 
locomotivas a vapor" (TRINDADE, 2000, p.85), o campo foi decididamente abandonado pela cidade, gerando ambiente mais do que propício para o início da revolução industrial: tecnologia e mão-de-obra barata e abundante. A estrutura de trabalho muda radicalmente, pois, se antes o trabalhador era servo, mantinha-se no entanto junto a sua família, trabalhando unidos, e podiam se servir dos frutos da terra de seu senhor, ainda que com todas as restrições conhecidas daquela situação.

Esse novo plano de economia e sociedade trouxe consequências vistas até em nossos dias. A classe mercantilista multiplicou não só a sua riqueza mas também o seu poder; o trabalho passa a ser visto como bem mercantil, regulado tão-somente pelas normas de mercado, o trabalhador não mais tem a propriedade do produto que efetivou, e a falta de trabalho - o tão famigerado e hoje mal do século desemprego - passa a ser uma espada na cabeça do trabalhador.

No antigo sistema de corporações de ofícios da época do feudalismo, os artesãos, como se sabe, eram donos de seus instrumentos e objetos de trabalho, produziam com habilidade pessoal cada artigo em sua casaoficina, do começo ao fim, para um mercado pequeno e estável e colhiam os resultados financeiros de sua atividade. No sistema manufatureiro, que havia se desenvolvido na Europa durante a fase inicial do capitalismo (mercantilismo, mais ou menos entre os séculos XVI e XVIII), essa independência do trabalhador deu o primeiro passo em direção ao desaparecimento: os artesãos quase sempre ainda eram proprietários de seus instrumentos, mas o crescimento e a instabilidade do mercado forçaram-nos a trabalharem por encomendas de capitalistas-mercadores, de que passaram, inclusive, a depender para o adiantamento das matériasprimas. (TRINDADE, 2000, p. 87)

Se o trabalho já era valorizado, com o advento da Revolução Francesa, que deita por terra o já fragilizado sistema feudal, e, posteriormente, na era industrial, o trabalho passa a ter valor social central, pois toda a vida capitalista gira em seu entorno:

Havia casos em que a antiga oficina já tendia a se expandir, agregando mais empregados e começando a introduzir uma divisão de trabalho com especialização de funções entre eles. Os artesãos, embora já estivessem se tornando tarefeiros-assalariados, ainda executavam pessoalmente quase todas as tarefas necessárias à produção de um artigo, mantendo o conhecimento do conjunto de seu processo produtivo. Com a Revolução Industrial, tudo se transformou: o empresário capitalista, dono dos novos meios de produção (máquinas, instrumentos, matérias-primas e instalações) passou a agrupar no seu estabelecimento grande número de assalariados sob seu comando e a habilidade individual perdeu importância, pois a fábrica mecanizada generalizou e radicalizou a 
divisão do trabalho, fragmentando a produção de cada artigo em etapas sucessivas e estanques, cada uma delas exigindo quase só movimentos repetitivos do trabalhador. (TRINDADE, 2000, p. 87)

Se antes, no sistema feudal, o trabalhador dependia da terra, ou seja, plantava e comia, ainda que em escassez, agora, com a prática liberal e o afastamento em massa do campo, a classe trabalhadora depende tão-somente do emprego para sobreviver. Assim, se antes a forma de distinção social era o nascimento, nessa nova estrutura passa a ser a má distribuição de renda. Se antes aquele que produziu o produto ficava com o pagamento integral ganho pela venda do bem, agora o empresário fica com a parcela integral de tudo quanto foi produzido por seus empregados, que recebem uma ínfima parte desse montante como contraprestação pelos serviços realizados - o salário.

Nessa busca de romper com o sistema que se instalara o filósofo Karl Marx ${ }^{35}$, escreve e divulga o célebre Manifesto do Partido Comunista:

A burguesia desempenhou na história um papel extremamente revolucionário. Onde quer que tenha conquistado o poder, a burguesia destruiu todas as relações feudais, patriarcais, idílicas. Dilacerou impiedosamente os variegados laços feudais que ligavam o ser humano a seus superiores naturais, e não deixou substituir de homem para homem outro vínculo que não o interesse nu (sic) e cru (sic), o insensível 'pagamento em dinheiro'. Afogou nas águas gélidas do cálculo egoísta os sagrados frêmitos da exaltação religiosa, do entusiasmo cavalheiresco, do sentimentalismo pequeno-burguês. Fez da dignidade pessoal um simples valor de troca (g.n.) e no lugar das inúmeras liberdades já reconhecidas e duramente conquistadas colocou a liberdade do comércio sem escrúpulos. Numa palavra, no lugar da exploração mascarada por ilusões políticas e religiosas colocou a exploração aberta, despudorada, direta e árida. A burguesia despojou de sua auréola todas as atividades até então consideradas dignas de veneração e respeito. Transformou em seus trabalhadores assalariados o médico, o jurista, o padre, o poeta, o homem da ciência. A burguesia rasgou o véu de comovente sentimentalismo que envolvia as relações familiares e as reduziu a meras relações monetárias. (MARX, ENGELS; 2000, P. 47-48)

A Igreja Católica passa a intervir na luta entre empregados e patrões, com o intuito de refrear a onda comunista que assolava o mundo, editando então a Encíclica Rerum Novarum e a Quadragésimo Anno, que, apesar de claramente terem surgido para manutenção da propriedade privada, tão interessante à maior proprietária do planeta,

\footnotetext{
${ }^{35}$ Para quem o trabalho decente, como já anteriormente verificado, jamais poderá ser identificado no sistema capitalista, visto que é um crítico do direito.
} 
renovava a afirmação de que o trabalho enobrece já advogada por São Bento e condenava a exploração desenfreada do homem contra o homem ${ }^{36}$.

Assim, o trabalho no sistema liberal capitalista passa a ser central na vida das pessoas e na vida da própria organização social como um todo.

No entanto, contemporaneamente, o trabalho, com o advento de novas tecnologias, novas formas de gestão, da globalização econômica e da precarização do trabalho, em um mundo onde o "chão de fábrica" é cada vez mais centralizado nos países que não têm restrições à exigência e condições de trabalho, e que as pessoas, pelos novos modelos de gestão, se expõe cada vez mais à exploração cruel de sua energia, vem sendo atingido por um discurso de superação de seu paradigma, onde o emissor desse discurso, defendendo seus interesses, propaga de diversos modos a idéia de que a sociedade fundada no valor central do trabalho tem se modificado estruturalmente, a ponto de sobrepujar o conflito entre capital e trabalho, o que faria prescindir da proteção legal à figura do trabalhador, que nesse contexto não é mais presumido hipossuficiente.

Como ilustração dessa realidade, pode-se perceber o crescente aumento no ambiente jurídico de soluções antes destoantes da lógica jurídica trabalhista, como a arbitragem, que pressupõe uma capacidade de contratação fundada em uma liberdade que o trabalhador não tem, e outras formas de solução extrajudiciais de conflito que dependeriam de uma independência que o operário, no sistema capitalista, jamais vai atingir, aplicando uma lógica privatística em uma relação que não é verdadeiramente privada ${ }^{37}$.

Destarte, o referido discurso neoliberal professa que a hipossuficiência do trabalhador, diante da contemporaneidade, não é um pressuposto, porque o conflito social no trabalho já não é o mesmo de antes; ora, a falácia desse juízo, de que o trabalho subordinado realizado dentro de uma jornada vem sendo eliminado, de onde se pode supor que o trabalho desqualificado foi suprimido, consiste na percepção de que o trabalhador continua sendo explorado, só que agora em uma perspectiva ainda pior, a da precarização do trabalho.

À guisa de exemplo, pode-se citar a mobilidade com que as empresas atualmente se deslocam em busca de mão-de-obra cada vez mais barata, de cada vez menos exigências em relação às condições de trabalho, e de benefícios fiscais e de outras naturezas concedidos pelos Estados.

\footnotetext{
${ }^{36}$ Ver capítulo III sobre o tema.

${ }^{37}$ Mesmo na concepção que admite a natureza privada das relações trabalhistas, se reconhece que os efeitos das relações de trabalho reverberam fortemente na esfera pública, como no caso do acidente de trabalho, que, para dizer o mínimo, impacta no orçamento público.
} 
$\mathrm{O}$ fato de que essas empresas podem se instalar rapidamente em qualquer lugar do planeta, aliado ao movimento ainda com fôlego de desregulamentação trabalhista e de globalização, faz com que o concreto valor social do trabalho se destaque ainda mais, pois aqueles que não o tem não são apenas marginalizados, mas efetivamente excluídos da convivência social, passam a não serem socialmente na lógica neoliberal.

Destarte, o que se evidencia, é a necessidade de adaptação do modelo jurídico trabalhista para coadunar com o movimento de resistência dos trabalhadores a tão maléficas mudanças. O conflito essencial entre capital e trabalho não esmoreceu, e as supostas transformações defendidas pelo capital não têm o condão de afirmar esta inverdade.

Nesse sentido, dizer que o valor do trabalho na contemporaneidade se modificou a ponto de alterar seu paradigma (conflito) não condiz com a realidade; ao contrário, o que se pode verificar é a necessidade cada vez mais forte de estabelecer condições de dignidade por meio da intervenção do Estado nas relações de trabalho, resguardando a dignidade do trabalhador e impondo limites bem demarcados no poder de contratação das partes daquela relação, a fim de que os indivíduos não deixem apenas de serem marginalizados, mas deixem de ser excluídos da sociedade.

No ordenamento jurídico trabalhista vigente, há expressamente a opção pela promoção e concretização do valor social do trabalho, que é contemplado na Constituição Federal de 1988, que em seu artigo $1^{\circ}$ o indica como um objetivo da República:

Art. $1^{\circ}$ A República Federativa do Brasil, formada pela união indissolúvel dos Estados e Municípios e do Distrito Federal, constitui-se em Estado Democrático de Direito e tem como fundamentos:

I - a soberania;

II - a cidadania;

III - a dignidade da pessoa humana;

IV - os valores sociais do trabalho (g.n.) e da livre iniciativa;

V - o pluralismo político.

Parágrafo único. Todo o poder emana do povo, que o exerce por meio de representantes eleitos ou diretamente, nos termos desta Constituição.

No teor integral do inciso IV do artigo $1^{\circ}$, pode-se imaginar que o valor social do trabalho encontra limites na livre iniciativa, ou seja, que constitucionalmente esses valores são antagônicos.

No entanto, observando uma análise sistemática do texto constitucional, pode-se perceber que o artigo 170, que fala da ordem econômica, traz indicativo de princípios, 
como a função social da propriedade (que não se limita à propriedade imóvel), redução de desigualdades, busca do pleno emprego, etc., que permitem a dedução de que os objetivos da República expostos no inciso IV do artigo $1^{\circ}$ (valores sociais do trabalho e livre iniciativa) são complementares, e que a livre iniciativa e a ordem econômica não podem se expandir fora dos limites do bem estar social.

Não é outra a conclusão a que chega José Afonso da Silva:

A livre iniciativa é fundamento da ordem econômica. Ela constitui um valor do Estado Liberal. Mas no contexto de uma Constituição preocupada com a realização da justiça social não se pode ter como um puro valor o lucro pelo lucro. Seus valores (possibilidade de o proprietário usar e trocar seus bens, autonomia jurídica, possibilidade de os sujeitos regularem suas relações do modo que lhes seja mais conveniente, garantia a cada um para desenvolver livremente a atividade escolhida) hoje, ficam subordinados à função social da empresa e ao dever do empresário de propiciar melhores condições de vida aos trabalhadores, exigidas pela valorização do trabalho. (2006, p. 39)

Marcus Orione Gonçalves Correia (2010) imprime a mesma preocupação no que respeita ao valor social do trabalho. Indica que hoje o trabalho é um desvalor, porquanto para o capital o valor econômico do trabalho é irrisório, havendo um enorme contingente de reserva formado. Chama a atenção para a necessidade de uma interpretação que aumente a potencialidade da expressão 'valor social do trabalho':

A única forma jurídica de o fazer 'inflar' de valor, para que possa
resgatar a solidariedade entre os trabalhadores e aumentar a consciência
de classe, é uma interpretação no direito que não descuide desse fator.
Portanto, se o valor econômico do trabalho é irrisório, o significado não
lhe pode ser atribuído enquanto valor social constante da expressão
constitucional,. Logo, juridicamente, há de se conceber uma alternativa
valorativa, real, coincidente com o que a Constituição denominou 'valor
social do trabalho'. Portanto, cabe aos juristas aumentar o nível
valorativo do trabalho, com esforço de interpretação, nos casos concretos,
neste sentido. No mundo capitalista, somente há uma forma de fazê-lo:
incorporando ao custo de produção a necessidade de preservação do
trabalho. Logo, não há outra alternativa: os juristas devem atribuir valor
econômico às soluções que envolvem a depreciação do trabalho humano,
por meio de interpretação jurídica, de tal forma que o valor deixe de ser
desvalor e passe a valor. (CANOTILHO, CORREIA E CORREIA, 2010,
p. 148)

A sociedade ainda se organiza entorno do trabalho, e também é certo que o conflito entre capital e trabalho ainda vige. Assim, permanecendo no âmbito social a estrutura de 
exploração do trabalho do homem pelo homem, o direito do trabalho deve estabelecer condições de resistência a essa exploração, ainda que tenha limites no sentido de possibilitar a reforma progressista do sistema, e não a transformação.

Ainda que, de certa forma, o Direito do Trabalho possa permitir a manutenção do sistema capitalista, o mais paradoxal é que, ao mesmo tempo, proporciona ao trabalhador uma melhor condição de trabalho. É dentro dessa realidade que se imprime a importância de um conceito de trabalho decente que afaste a exclusão social do trabalhador.

\subsubsection{A exclusão social pelo trabalho degradante}

A análise da exclusão social será realizada por meio de levantamento e tratamento de dados, inclusive estatísticos, que possam auferir ou ao menos suscitar de que modo o trabalho degradante auxilia neste processo ${ }^{38}$. Para tanto, serão verificadas estatísticas tanto de inclusão quanto de exclusão social, na medida em que ambas colaborem para a análise do tema proposto.

De início, referir-se-á a indicação estatística do DIEESE (Departamento Intersindical de Estatística e Estudos Socioeconômicos) sobre emprego e desemprego.

Note-se que, juridicamente, emprego se refere ao trabalho subordinado, oneroso, realizado de forma personalíssima por uma pessoa física, habitualmente. Para fins estatísticos, o DIEESE, em relação à Pesquisa de Emprego e Desemprego (PED) traz outra concepção do termo, com características diversas. O referido órgão esclarece a elaboração de sua metodologia, indicando quais são as características mais marcantes do mercado de trabalho para os fins da PED:

A elaboração da metodologia da PED pretendeu dar expressão a comportamentos típicos de um mercado de trabalho pouco estruturado, com grande disponibilidade de mão-de-obra e dinamizado por uma estrutura produtiva marcada por grandes diferenças entre as empresas (tamanho, tecnologia, participação no mercado, etc.), no qual:

38 Destaque-se que esses elementos não exaurem as possibilidades de aferição do impacto do trabalho decente para a exclusão social. 
- apenas cerca de metade dos trabalhadores é contratada segundo as regras vigentes, tendo acesso às garantias oferecidas pela legislação do trabalho; no entanto, a grande maioria está submetida a alta rotatividade, baixos salários e jornadas de trabalho extensas;

- o assalariamento sem carteira de trabalho assinada e o trabalho autônomo constituem parte expressiva do conjunto de ocupados, cuja precariedade de inserção decorre da falta de acesso ao contrato de trabalho padrão, da descontinuidade da relação de trabalho e da instabilidade de rendimentos;

- os mecanismos de proteção aos desempregados são muito limitados, em termos de duração e valor do benefício recebido; ademais, a proporção de trabalhadores que pode requerer o seguro desemprego é relativamente pequena. (...) (DIEESE, 2009)

Sendo assim, a concepção adotada pela legislação sobre emprego diverge grandemente da expressada pelo DIEESE, haja vista que as características acima relatadas foram consideradas para criar os critérios metodológicos do órgão. Acredita a Instituição referida que, em não se considerando as características apontadas, deixará de mapear estatisticamente o mercado de trabalho real, como se vê do modo de realização da pesquisa apontado:

Como consequência dessas características, a dinâmica desse mercado de trabalho não é suficientemente captada se adotadas as noções usuais de emprego - exercício de qualquer atividade por no mínimo uma hora na semana da entrevista - e desemprego ausência de trabalho combinada à procura e disponibilidade para trabalhar. Ou seja, a dicotomia emprego/desemprego aberto é insuficiente para descrevê-lo.

Frente às limitações impostas às análises sobre o mercado de trabalho brasileiro pelo uso dos conceitos mais tradicionais, o propósito básico da PED foi construir indicadores mais adequados à situação nacional, preservando a possibilidade de obter os indicadores frequentemente adotados em diferentes países.

Diante do movimento de precarização do mercado de trabalho brasileiro observado no período recente, a maior amplitude 
metodológica da PED tem se mostrado bastante adequada à captação das mudanças em curso. Ademais, as agências que analisam o mercado de trabalho de outros países têm sugerido a reformulação das pesquisas sobre o tema, demandando alterações em muitos casos similares às promovidas pela PED (Pesquisa de Emprego e Desemprego). (DIEESE, 2009)

Aparentemente, a pesquisa foi realizada a partir de critérios objetivos e lógicos, o que de fato ocorre. No entanto, quando da divulgação das estatísticas, a informação divulgada pela mídia impressa e falada é de índice de emprego e desemprego, sendo certo que a população absorve esta informação a partir dos parâmetros que tem, ou seja, a partir de dados conhecidos. Quando se fala em emprego, a população, pode-se afirmar com certo grau de precisão, pensa em "carteira assinada" - a representação popular de emprego - que coaduna com a concepção legal.

Assim, ao ler ou ouvir a informação estatística do nível de emprego/desemprego, não se tem notícia de que as diretrizes metodológicas que foram utilizadas não correspondem à concepção geral de emprego que tem o homem médio.

Ao se noticiar índice de emprego/desemprego, o receptor capta a mensagem imaginando tratar-se de emprego com carteira de trabalho assinada, e não qualquer tipo de trabalho, gerando para esses receptores a idéia - errada - de que há um percentual, especificado pelo Órgão, de pessoas sem emprego, quando na realidade este índice é muito maior, pois na metodologia da pesquisa o termo emprego não tem o mesmo significado que a legislação atribui ou mesmo o senso comum, como se pode depreender das informações metodológicas da PED acima expostas.

Não apenas o termo emprego tem acepção distinta da apresentada pela legislação ou pelo senso comum. O termo desemprego, pelo senso comum, significa que o utilizado pelo DIEESE também tem um conceito diferente, e é apresentado como falta de emprego $^{39}$. Assim, desempregado é aquele que está sem emprego, não por vontade própria. Para o DIEESE, na PED, significa aquele que não tem trabalho (qualquer que seja a espécie de trabalho):

\footnotetext{
${ }^{39}$ No dicionário Houass, o termo desemprego significa falta de emprego, ociosidade involuntária daqueles que estão dispostos a trabalhar e não encontram quem os empregue.
} 
Desempregados - São indivíduos que se encontram numa situação involuntária de não-trabalho, por falta de oportunidade de trabalho, ou que exercem trabalhos irregulares com desejo de mudança. Essas pessoas são desagregadas em três tipos de desemprego:

- desemprego aberto: pessoas que procuraram trabalho de maneira efetiva nos 30 dias anteriores ao da entrevista e não exerceram nenhum trabalho nos sete últimos dias;

- desemprego oculto pelo trabalho precário: pessoas que realizam trabalhos precários - algum trabalho remunerado ocasional de auto-ocupação - ou pessoas que realizam trabalho não-remunerado em ajuda a negócios de parentes e que procuraram mudar de trabalho nos 30 dias anteriores ao da entrevista ou que, não tendo procurado neste período, o fizeram sem êxito até 12 meses atrás;

- desemprego oculto pelo desalento: pessoas que não possuem trabalho e nem procuraram nos últimos 30 dias anteriores ao da entrevista, por desestímulos do mercado de trabalho ou por circunstâncias fortuitas, mas apresentaram procura efetiva de trabalho nos últimos 12 meses. (DIEESE, 2009)

De acordo com a padronagem estabelecida pelo Órgão, emprego e desemprego se assemelham muito mais a trabalho e não trabalho, respectivamente, do que a noção nem sequer legislativa, mas do senso comum sobre tais vocábulos.

Assim, o que se lê, repise-se, é que o índice de desemprego na Cidade de São Paulo, em novembro de 2009, foi de $12,8 \%{ }^{40}$, acreditando, assim, o senso comum, que estão sem emprego de "carteira assinada" $12,8 \%$ da população de São Paulo, não imaginando que, se um indivíduo realizou um "bico" 41 " nos últimos sete dias não está considerado na faixa do desemprego. A opinião popular sobre o assunto fica ilusionada, pois, construíram os resultados apresentados não a partir dos critérios reais em que foram fixados, mas a partir da rede de conhecimentos que já haviam adquirido.

Essas estatísticas, apesar de bem produzidas naquilo que se propõem, são perigosas e falseiam situações quando não devidamente avaliadas diante de suas metodologias. Assim, a PED não poderia servir como indicativo de emprego e desemprego nos termos da

\footnotetext{
${ }^{40} \mathrm{Cf}$. em DIEESE, <http://www.dieese.org.br/ped/sp/pedrmsp1109.pdf $>$.

${ }^{41}$ Termo coloquial que significa trabalho sem vínculo, de curto prazo.
} 
legislação, nem poderiam ser pauta para políticas públicas de emprego, já que a concepção de emprego e desemprego que denota é específica para a pesquisa, não corresponde nem à noção legal nem ao senso comum.

Nem mesmo no cenário político os termos emprego e desemprego são sinônimos de trabalho/falta de trabalho. Tanto é assim, que dentro do próprio Governo a temática tem tratamento diferenciado, haja vista o nome do Ministério que cuida desta pasta (emprego). O nome é Ministério do Trabalho e Emprego, que fala por si, demonstrando claramente que tais termos têm acepções distintas.

O IPEA ${ }^{42}$ também utiliza acepção distinta da legal para apresentar a taxa de desemprego, conforme se denota das estatísticas e comentários abaixo indicados, basicamente com as mesmas distorções apresentadas pelo DIEESE:

\section{Taxa de desemprego - áreas metropolitanas}

Periodicidade: Anual

Fonte: Instituto Brasileiro de Geografia e Estatística

Unidade: (\%)

Comentário: Percentual das pessoas residentes em áreas metropolitanas que procuraram, mas não encontraram ocupação profissional remunerada entre todas aquelas consideradas "ativas" no mercado de trabalho, grupo que inclui todas as pessoas com 10 anos ou mais de idade que estavam procurando ocupação ou trabalhando na semana de referência da Pesquisa Nacional por Amostra de Domicílios (Pnad). Elaboração: Disoc/Ipea.

\begin{tabular}{|c|c|c|c|c|c|}
\hline Brasil & 2003 & 2004 & 2005 & 2006 & 2007 \\
\hline BR-Brasil & 14,1 & 13,5 & 13,4 & 12,1 & 11,3 \\
\hline
\end{tabular}

O mesmo órgão, entretanto, quando traz o indicativo de emprego, já o faz com base no conceito celetista (legal, portanto) do termo, como se pode depreender da estatística a seguir colacionada ${ }^{43}$.

Empregados

Periodicidade: Mensal

Fonte: Ministério do Trabalho e Emprego, Cadastro Geral de Empregados e Desempregados (MTE/CAGED)

Unidade: Pessoa

Comentário: O saldo refere-se ao total de admissões e dispensa de empregados, sob o regime

\footnotetext{
${ }^{42}$ Cf. em IPEA,

$<$ http://www.ipeadata.gov.br/ipeaweb.dll/ipeadata?SessionID $=1754859544 \&$ Tick=1262742210281\&VAR_F $\mathrm{UNCAO}=$ Ser_Temas $\% 282060023838 \% 29 \& \mathrm{Mod}=\mathrm{S}>$

${ }^{43}$ Cf. IPEA, disponível em

$<$ http://www.ipeadata.gov.br/ipeaweb.dll/ipeadata?SessionID=1754859544\&Tick=1262742790828\&VAR_F $\mathrm{UNCAO}=$ RedirecionaFrameConteudo $\% 28 \% 22$ iframe_dados_m.htm $\% 22 \% 29 \& \mathrm{Mod}=\mathrm{M}>$, bem como anexo do trabalho.
} 
da Consolidação das Leis do Trabalho - CLT. (grifo nosso)

Atualizado em: 04 de dezembro de 2009

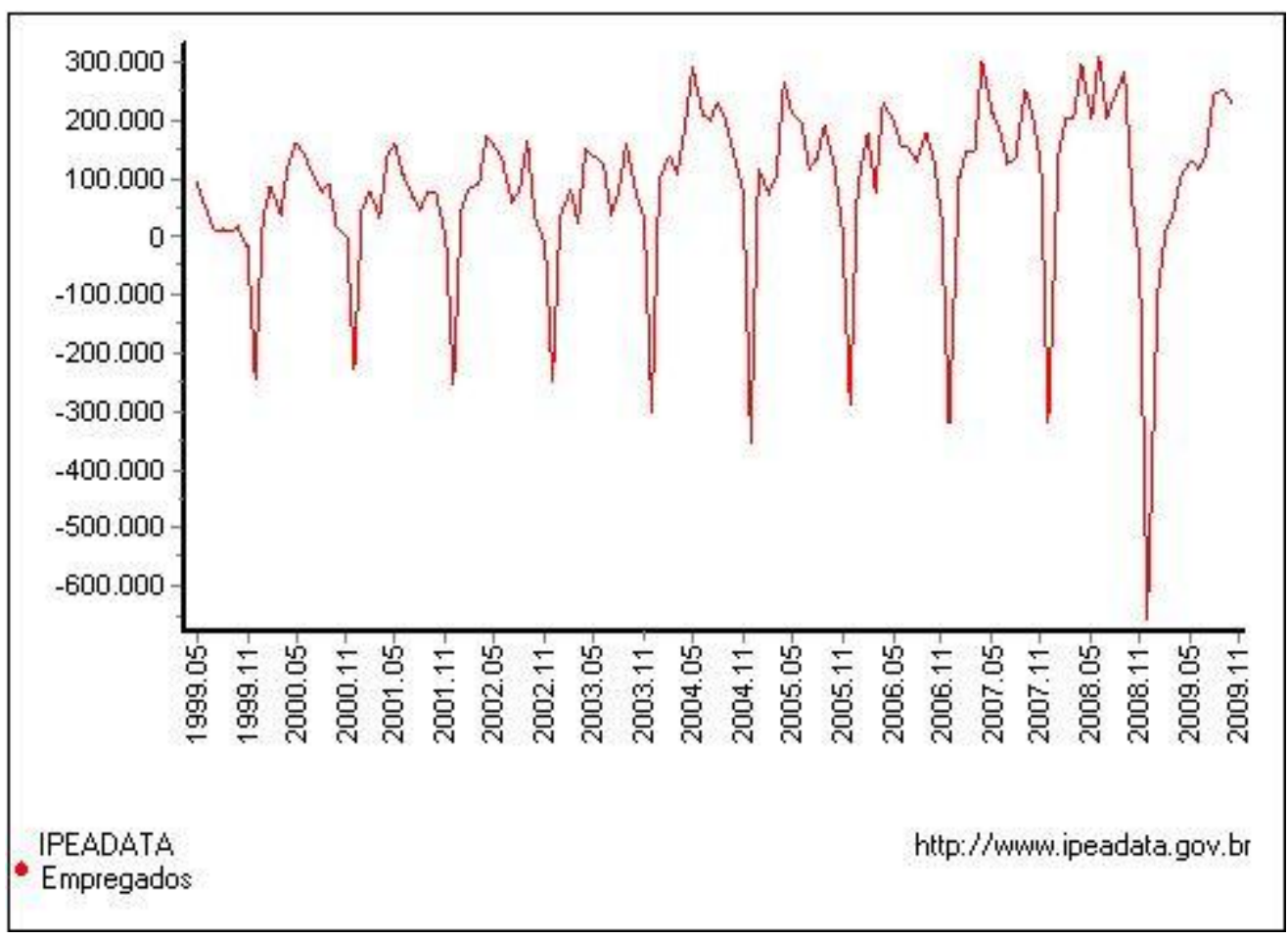

Tais distinções, longe de serem meramente conceituais, são de extrema relevância considerando-se que em 2003, 45,5\% dos assalariados estavam em condição de informalidade, ou seja, de trabalho assalariado sem registro na carteira de trabalho, o que representa quase metade da população assalariada.

No tocante à população jovem, as estatísticas demonstram dois fatores interessantes, especialmente se analisados em conjunto. É uma faixa da população que encontra enorme dificuldade de alcançar um emprego, bem como é ainda uma das faixas onde mais ocorrem homicídios, como demonstra o levantamento abaixo colacionado, realizado pelo PNUD realizado em 1996:

O crescimento do número de jovens fez aumentar a pressão sobre o mercado de trabalho, em crise há duas décadas. A queda da renda também colaborou para o aumento da demanda por empregos: com os chefes de domicílio ganhando menos, os membros mais jovens da família são empurrados ao mercado de trabalho para ajudar a recompor a renda familiar. "O problema é que os jovens forçam o mercado de trabalho - inclusive por conta da dificuldade dos pais 
—, mas o mercado está fechado. Sem emprego, muitos vão para outras direções, envolvem-se com drogas, partem para a criminalidade. E, com isso, puxam para o alto as taxas de homicídio", explica Celso Simões. Os números da cidade de São Paulo seguem a mesma tendência da estatística nacional. A taxa de mortalidade infantil paulistana caiu de 19,9 por mil nascidos vivos para em 1996 para 14,8 por mil em 2001 - uma queda de $26 \%$. Ao mesmo tempo, a taxa de homicídios de jovens na cidade subiu $20 \%$ - de 96,1 assassinatos por 100 mil habitantes para 124,2 por 100 mil (segundo dados da Pro-Aim, da Prefeitura de São Paulo). ${ }^{44}$

Em 2004, o Ministério da Saúde ${ }^{45}$ demonstra dados indicando o aumento de homicídio entre jovens do gênero masculino, entre 20 e 29 anos, onde a taxa de mortalidade (por 100.000), no Brasil, é de 115,8. Entre os 15 e 19 anos, a taxa é de 76,9, sendo seguida pela faixa entre 30 e 39 anos, com 76,4, e, por fim, a faixa etária mais elevada, dos 40 aos 49 anos, registrando a menor taxa, com 52,1.

Dados do Ministério da Justiça (PIRES, GATTI; 2006), do censo penitenciário de 1995, demonstram a mesma ligação entre a faixa etária mais jovem e a criminalidade, informando que a maior parte da população carcerária são jovens:

$\begin{array}{lrcr}\text { Faixa Etária } & \text { Homens } & \text { Mulheres } & \text { Total } \\ 18 \text { a 24 anos } & 2.530 & 120 & 2.650 \\ 25 \text { a 29 anos } & 1.997 & 80 & 2.077 \\ 30 \text { a 34 anos } & 1.136 & 73 & 1.209 \\ 35 \text { a 45 anos } & 973 & 46 & 1.019 \\ 46 \text { a 60 anos } & 274 & 11 & 285 \\ \text { Mais de 60 anos } & 20 & 4 & 24\end{array}$

O Mapa da Violência nos Municípios Brasileiros noticia que "entre 1994 e 2004, os homicídios na população jovem saltaram de 11.330 para 18.599, com aumento decenal de $64,2 \%$, crescimento bem superior ao da população total: 48,4\%"46. (OEI, 2004, p.67) Destarte, as estatísticas demonstram que apesar de ter havido uma redução dos índices de homicídio, no cômputo geral, para a faixa dos jovens, o fenômeno é oposto, ocorreu, de fato, um aumento considerável do número de homicídios.

\footnotetext{
${ }^{44} \mathrm{Cf}$. em $<$ http://www.pnud.org.br/gerapdf.php?id01=228>.

${ }^{45} \mathrm{Cf}$. em Saúde Brasil 2004: Uma análise da situação da saúde, p.287.

${ }^{46} \mathrm{Cf}$. em $<$ http://www.oei.es/noticias_oei/mapa_da_violencia_baixa.pdf $>$.
} 
Não surpreende que a taxa de desemprego mais alta, segundo dados do IPEA, se estabelece na categoria dos jovens, indicando a pesquisa que, "em termos absolutos (isto é, em relação à distribuição uniforme) o desemprego está concentrado entre os homens, jovens (trabalhadores com idade entre 10 e 29 anos) (...)” (IPEA, 1997, p.21)

No estudo intitulado Situação do jovem no mercado de trabalho no Brasil: um balanço dos últimos 10 anos, Pochmann indica que:

Em 2005, por exemplo, a quantidade de jovens desempregados era quase $107 \%$ superior a de 1995 , enquanto o desemprego para a população economicamente restante do país foi 90,5\% superior nos últimos 10 anos. Da mesma forma, nota-se a rápida expansão na taxa nacional de desemprego dos jovens, com variação de 70,2\% (de 11,4\% para 19,4\%), enquanto a taxa nacional de desemprego da parte restante da PEA aumentou 44,2\% entre 1995 e 2005 (de 4,3\% para 6,2\%). Já a taxa nacional de desemprego para o conjunto da PEA brasileira cresceu 52,4\% no mesmo período de tempo, passando de $6,1 \%$ para $9,3 \%$. (2007, p. 3 )

Outros dados muito relevantes, alcançados na pesquisa intitulada "A condição socioeconômica e os direitos sociais dos presos da Penitenciária Estadual de Maringá" (BRITO, LIMA, ROSSI; 2004), apesar de serem obtidos a partir de uma abordagem regional, acredita-se que reflitam muito da realidade nacional, e respeitam à profissão dos pais dos detentos, e levam a crer na estreita ligação entre trabalho degradante, desemprego e violência.

Constatamos que as principais profissões exercidas pelos pais dos presos da PEM, no período da pesquisa, foram a de lavrador com 43,14\%; seguidas da de pedreiro com $10,57 \%$; servente de pedreiro com $6,57 \%$; motorista com 6,57\%; Isto nos mostra que a maior parte dos setores econômicos em que os pais dos presos trabalhavam eram atividades ligadas a Agricultura e a Construção Civil, na qual somam juntas 66,56\% dos pais dos entrevistados. Estas informações nos indicam que os pais dos presos possuem um status inferiorizado com poucas possibilidades de dar uma educação formal que permitam a profissionalização de seus filhos. Que 54,57\% das mães dos presos não trabalham fora de casa, e que as profissões mais exercidas por elas foram: doméstica/diarista com 
$17,71 \%$, seguidas pela de lavradora com $12 \%$ e a de costureira com $5,43 \%$ o que representa $77,34 \%$ das mães dos presos que trabalham. Estes dados nos sugerem que, se por um lado $54,57 \%$ das mães dos presos não colaboram na manutenção do lar, a fim de dar melhores condições de saúde, alimentação, lazer, educação, moradia e outras necessidades, por outro $45,43 \%$ das mães não contribui na educação e formação dos filhos de uma maneira integral e mais próxima, uma vez que estão buscando compor o orçamento da família, mas com péssima remuneração em função das profissões desempenhadas.

As estatísticas apontam que esses setores, da agricultura e da construção civil, apresentam números significativos no que toca a acidente do trabalho e más condições de trabalho, demonstrando as condições subumanas a que são expostos seus trabalhadores.

Todeschini (2008) afirma que nesses setores, é grande a informalidade e as más condições de trabalho. $\mathrm{Na}$ agricultura, por exemplo, são inúmeros os riscos enfrentados pelos trabalhadores, a saber, "escoriações por manuseio de materiais; poeiras; ergonômicos; impactos de objetos; radiações solares; equipamentos cortantes; dermatológicos; agrotóxicos; biológicos (animais peçonhentos); peças móveis de máquinas, entre outros".

Traduzindo em dados, aduz o referido autor que, apesar de um pequeno recuo da taxa de acidentes do trabalho na área rural em relação ao número total de acidentes, de 8,46\% em 2003 para 7\% em 2005, é alto o índice de mortalidade neste setor, de 9,27\% em 2005. Na exploração florestal, cresceu cerca de 64,38 em relação à taxa total Brasil; no cultivo de soja, passou de 47,30 em 2004 para 73,15 em 2005; no setor sucroalcooleiro (cultivo de cana, usinas de açúcar e álcool), houve uma variação de 47,17 a 75,14, o que equivale a 2,4 a 3,8 vezes maiores que a taxa de acidentes no Brasil (19,51). De acordo com dados da FUNDACENTRO (Todeschini, 2008), "boa parte desses acidentes é decorrente de uma série de máquinas e equipamentos sem proteção, como: serra circular de fita e tupia; motosserras; cilindro de massas; injetoras de plástico; prensas mecânicas e similares máquinas agrícolas e florestais".

No setor da construção civil, a realidade apresentada não é muito diferente, conforme dados levantados por Todeschini, já que apresenta constantemente taxas elevadas de mortalidade em acidentes do trabalho, que giram em torno de $11 \%$, principalmente por quedas, soterramentos e choques elétricos. 
Uma investigação realizada em um Hospital Universitário da cidade de Ribeirão Preto/SP, por meio dos prontuários hospitalares, avaliou nas anotações efetuadas por profissionais da equipe de saúde, a incidência de acidentes de trabalho ocorridos e suas possíveis relações com a ocupação dos pacientes/trabalhadores, durante dois anos consecutivos. Dos 6.122 prontuários, $150(2,45 \%)$ eram de trabalhadores da construção civil, sendo que a maioria dos pacientes eram da faixa etária entre os 31 e 40 anos (34,7\%), todos homens. As causas predominantes dos acidentes foram as quedas (37,7\%). Outro dado muito relevante da pesquisa e que podem confirmar a hipótese de que muitos assalariados da construção civil não foram registrados formalmente, é que em nenhum prontuário pesquisado encontrou-se uma via da Comunicação de Acidente de Trabalho (CAT). (SILVEIRA, ROBAZZI, WALTER, MARZIALE, 2005)

Dados indicados no título Trabalho Decente nas Américas 2006-2015, realizado pela OIT (2006a), refletem as mesmas informações, noticiando o aumento do número de acidente fatais na América Latina, quando a média mundial, com exceção da já referida América Latina e China. Constata ainda que dentre os setores mais atingidos pela mortalidade dos acidentados encontram-se o trabalho em área rural e na construção civil, conforme o que se especifica abaixo:

Os dados disponíveis indicam que, em 2001, ocorreram 30 milhões de acidentes relacionados com o trabalho na América Latina, com quase 40 mil mortes. Mais ainda, a América Latina é a região com maior índice de aumento de acidentes fatais no período 1998-2001. Com exceção de América Latina e China, a tendência mundial dos últimos anos foi de redução dos acidentes fatais. Os trabalhadores menos protegidos concentram-se nas micro e pequenas empresas da economia informal e em setores como agricultura, mineração, pesca e indústria da construção.

No entanto, dados do MTE demonstram que a fiscalização do trabalho se deu fortemente justamente nesses dois setores. Causa estranhamento que a fiscalização tenha sido tão expressiva nestes setores e que os dados nacionais traduzam pouca participação da 
agricultura e da construção civil no número de acidentes do trabalho. São os dados do Ministério $^{47}$ :

\section{Dados da Inspecáo em Sequranca e Saúde no Trabalho - Brasil}

\begin{tabular}{|c|c|c|c|c|c|c|c|}
\hline \multicolumn{2}{|c|}{ Setor Económico } & $\begin{array}{l}\text { Açōes } \\
\text { Fiscais }\end{array}$ & $\begin{array}{c}\text { Trabathadores } \\
\text { alcançados }\end{array}$ & Notuficaçóes * & Autuaçós * & $\begin{array}{l}\text { Embargos I } \\
\text { Interdlcoes }\end{array}$ & $\begin{array}{l}\text { Acidentes } \\
\text { analisados }\end{array}$ \\
\hline \multicolumn{2}{|l|}{ Agricultura } & 10.101 & 1.136 .248 & 12.402 & 7.048 & 180 & 65 \\
\hline \multicolumn{2}{|l|}{ Combrelio } & 34,218 & $2.631,894$ & 20.910 & 4.776 & 380 & 183 \\
\hline \multicolumn{2}{|l|}{ Construchio } & 30.782 & 2260.266 & 14.972 & 12.787 & 3.032 & 418 \\
\hline \multicolumn{2}{|l|}{ Educaçlio } & 2.321 & 284.981 & 256 & 178 & 8 & 5 \\
\hline \multicolumn{2}{|c|}{ Hotbis/Restaurantes } & 5.202 & 254.327 & 1.365 & 640 & 14 & 25 \\
\hline \multirow{7}{*}{ Indústria } & Ind. Allimentos & 5,582 & 1.455 .254 & 3.537 & 2080 & 172 & 104 \\
\hline & Ind. Madeira e Papel & 2.140 & 184.827 & 1.501 & 692 & 91 & 36 \\
\hline & Ind. Metal & 8,417 & 1.539 .859 & 9.098 & 3.185 & 298 & 219 \\
\hline & Ind. Mineral & 3.497 & 355.044 & 4.693 & 2.919 & 245 & 85 \\
\hline & Ind. Quimioos & 3.071 & 740.938 & 2535 & 1.450 & 76 & 87 \\
\hline & Ind. Tecide \& Couro & 5.078 & 669.617 & 3.186 & 890 & 34 & 32 \\
\hline & IndGetrlas - Outras & 1.960 & 169.120 & 1.172 & 444 & 35 & 55 \\
\hline \multicolumn{2}{|c|}{ Institulcōes Financelras } & 1.448 & 498.303 & 357 & 309 & 5 & 5 \\
\hline \multicolumn{2}{|l|}{ Saúde } & 8.411 & 1.047 .098 & 8.322 & 1,258 & 34 & 30 \\
\hline \multicolumn{2}{|l|}{ Serviços } & 8.923 & 2.630 .201 & 3.737 & 2.519 & 107 & 131 \\
\hline \multicolumn{2}{|l|}{ Transporte } & 8.832 & 1.901 .684 & 2836 & 1,539 & 57 & 97 \\
\hline \multicolumn{2}{|l|}{ Outros } & 3.541 & 830,375 & 1.115 & 676 & 47 & 32 \\
\hline & TOTAL & 144.624 & 18.590 .046 & 93.094 & 43.400 & 4.815 & 1.620 \\
\hline
\end{tabular}

Pela apresentação dos dados e estatísticas selecionados, pode-se perceber que não é necessariamente a pobreza que exclui, mas que um fator determinante do trabalho degradante é a informalidade. Os subsídios oferecidos indicam que a informalidade aproxima os trabalhadores das piores formas de degradação no meio ambiente laboral, no sentido mais abrangente desse termo.

No que toca à exclusão social, foi este o importante levantamento realizado na coleção Atlas da Exclusão Social no Brasil ${ }^{48}$, que tem como um de seus organizadores Márcio Pochmann. Este trabalho, referência sobre o tema, traz informações que desmistificam e concretizam novos parâmetros sobre a exclusão social. Segundo os autores, o que mais influencia a exclusão não é a pobreza, mas a desigualdade, conforme será debatido no subitem seguinte. A tabela abaixo traz informações acerca dos dez Municípios que menos excluem, em azul, e os dez Municípios que mais excluem, em vermelho. São os índices:

\footnotetext{
${ }^{47}$ Sistema Federal de Inspeção do Trabalho

${ }^{48} \mathrm{Cf}$. em $<$ http://www.universia.com.br/materia/materia.jsp?id=1201>.
} 


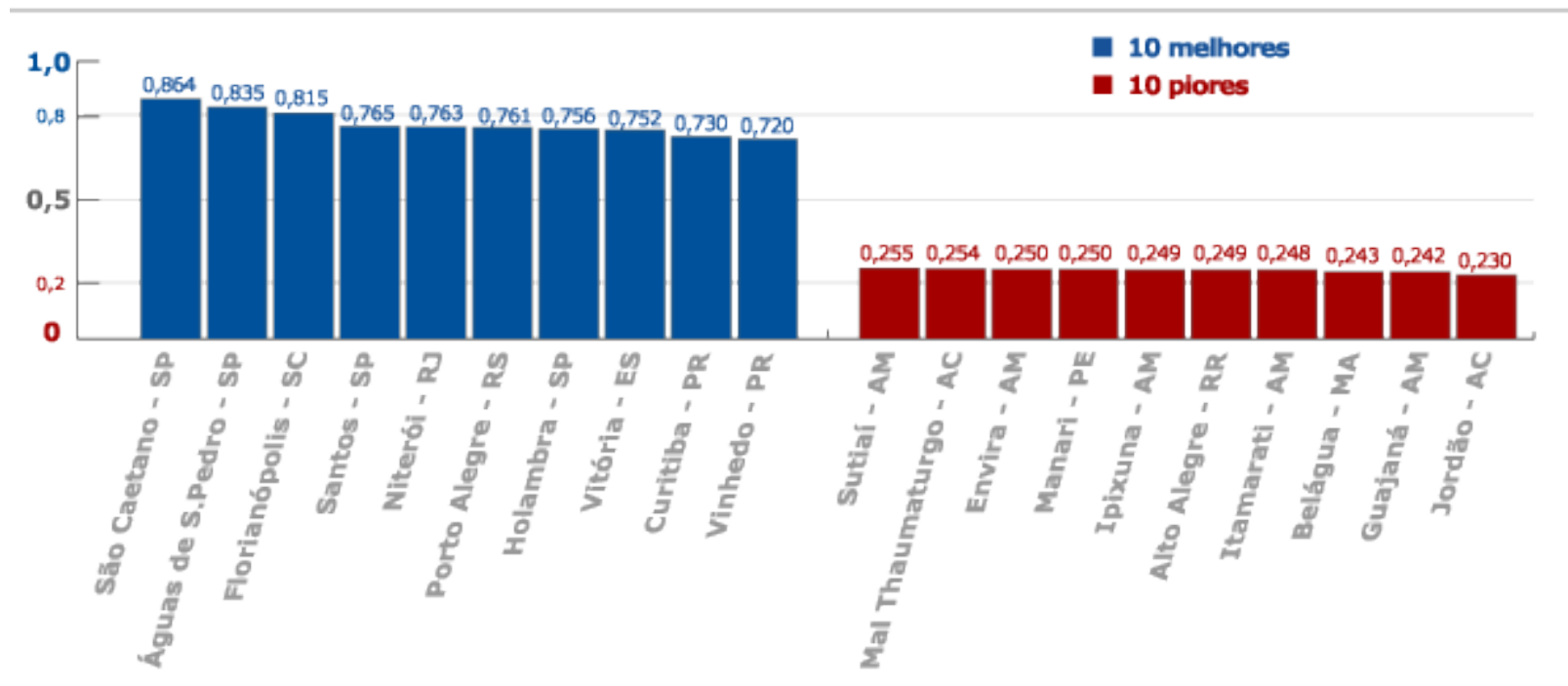

Fonte: Atlas da Exclusbao Social no Brasil; Cortez Editora

A pesquisa revela também que nas grandes cidades, apesar de obviamente existir de modo considerável a exclusão social, a camada da população mais pobre encontra ainda melhores condições de vida do que de seus lugares de origem, haja vista que esses Municípios oferecem escola pública, hospitais públicos, saneamento básico, mesmo que essa oferta não seja absoluta ou que os serviços sejam prestados com grande nível de qualidade.

Como, normalmente, esses Municípios concentram, por serem os mais desenvolvidos, a camada mais rica da população, os dados gerais podem transmitir equívocos, como explica o pesquisador Amorim:

$\mathrm{Na}$ capital paulista, que apesar de contar com grande parcela da população em condições precárias, o índice de desigualdade está entre os melhores do país, pois a minoria que desfruta de alta renda acaba por equilibrar a situação do município. "Por São Paulo ser um centro mais desenvolvido você acaba diluindo, na média, as grandes diferenças internas da cidade", lamenta Amorim. (Universia, 2003)

Diante dos dados expostos pode-se perceber como o trabalho degradante está intimamente ligado à questão da exclusão social, sendo mesmo um elemento que traduz a desigualdade social. Quanto mais formalizado o trabalho, menos exposto está o trabalhador, ainda que a proteção legal não o afaste completamente do trabalho degradante. 
É inegável, porém, que a informalidade e a intermediação de mão-de-obra aproxima de forma nefasta o trabalhador da degradação no labor, como se verá a seguir.

\subsubsection{Impactos sociais do trabalho degradante}

A integração social através do trabalho é uma realidade, pois no ambiente laboral as pessoas encontram amigos, namorados, companheiros, tutores, ampliando sua rede social e, consequentemente, suas oportunidades de vida, em todos os sentidos, não apenas no aspecto profissional. $\mathrm{O}$ ambiente de trabalho pode afetar favorável e desfavoravelmente a vida do trabalhador, dependendo da qualidade daquela atmosfera.

A relação entre exclusão social e violência é estreita, e são inúmeros os projetos que procuram viabilizar a inclusão social através do trabalho, ou pela disponibilização de postos de emprego ou pela qualificação profissional para que o trabalhador desempregado possa alcançar uma vaga no mercado de trabalho.

À guisa de exemplo, vale ressaltar o projeto Começar de Novo, desenvolvido e promovido pelo Conselho Nacional de Justiça (CNJ), cujo objetivo é reinserir o expresidiário na sociedade, através do trabalho. Outro programa que procura promover a inserção social através do trabalho é o programa GRPE (gênero, raça, pobreza e emprego), cujo objetivo é auxiliar na erradicação da pobreza e gerar empregos observando a questão de gênero e raça, denota que o trabalho decente é realmente determinante para uma agenda pública de inclusão social:

O fato de ter acesso a um trabalho, assim como as condições em que esse é exercido, são fatores determinantes das possibilidades que os indivíduos e os grupos sociais têm de evitar ou superar uma situação de pobreza e exclusão social. O desemprego, o emprego precário ou mal remunerado, informal, instável, exercido muitas vezes em condições desumanas e degradantes, são elementos essenciais para explicar porque as pessoas vivenciam uma situação de pobreza. Ao contrário, ter um trabalho digno é a via fundamental para sair dessa situação. (OIT, 2006b) 
O trabalho é elemento central da sociedade, e é através dele que a vivência se torna possível para a esmagadora maioria das pessoas. $\mathrm{O}$ trabalho proporciona renda para atingir os bens necessários ao desenvolvimento da vida, como a obtenção de moradia, da alimentação, do vestuário, da educação, da saúde de todas as outras condições para o desenvolvimento humano, parâmetros estabelecidos no artigo $6^{\circ}$ da $\mathrm{CF} / 88$ :

Art. $6^{\circ}$ São direitos sociais a educação, a saúde, a alimentação, o trabalho, a moradia, o lazer, a segurança, a previdência social, a proteção à maternidade e à infância, a assistência aos desamparados, na forma desta Constituição.

Se a sociedade se funda na idéia de que o trabalho eleva a condição humana, e se é certo que é o trabalho que proporciona o acesso aos bens da vida, ele não pode ser negado como um direito que é, nem deixar de irradiar os valores que carrega para a esfera política e jurídica.

Nessa toada, estar sem trabalho é estar excluído socialmente, nas diferentes esferas de segregação (econômica e social), e os dados coletados demonstram claramente a íntima ligação entre trabalho degradante/desemprego e exclusão social.

A questão da exclusão social pelo trabalho se inicia já no processo seletivo para uma vaga de emprego. Tome-se como exemplo o objeto do programa Começar de Novo do CNJ. A passagem do indivíduo no sistema prisional, ou seja, a constatação de que ele cometeu um ilícito penal, sua condenação e cumprimento de pena diante da máquina estatal, no mercado de trabalho, não é relevante. O dado relevante é apenas o que informa que tal pessoa tem ficha criminal, ou seja, cometeu um crime. Se já foi condenado, já cumpriu sua pena e está buscando a ressocialização, é fator de menos ou nenhuma importância. Esse dado se agrava se com a constatação de que uma das faixas etárias que mais se destaca por ser atingida pela violência é a dos jovens.

O jovem já é discriminado no mercado pela sua pouca ou nenhuma experiência, e, como se viu na pesquisa intitulada Situação do jovem no mercado de trabalho no Brasil: um balanço dos últimos 10 anos, encabeçada por Pochmann, que indica que esta faixa etária é tremendamente atingida pelo desemprego, esta condição carrega estes indivíduos para o subemprego e para a violência, demonstrando claramente como o trabalho degradante ou o desemprego marginalizam e excluem o ser humano do ambiente social. 
Os dados colacionados noticiam que a desigualdade conduz à violência. Relacionou-se acima uma pesquisa que demonstra que uma grande parcela dos pais dos detentos da Penitenciária de Maringá trabalhava na agricultura ou na construção civil. Outras pesquisas demonstraram que as condições de trabalho nesses setores são ruins, ampliando o fosso da desigualdade.

Quer parecer que este quadro denota um ciclo retroalimentador, na medida em que o trabalho degradante/desemprego mantém o indivíduo na pobreza e na desigualdade social, afetando diretamente sua família, onde o ambiente de violência que sofre muitas vezes é reproduzido, pois, buscando esses jovens meios de sair da condição de pobreza e desigualdade, não os encontram eficazes na sociedade, pois são altamente atingidos pelo desemprego e pelo trabalho precário, situação que os empurra para a obtenção dos bens da vida através de meios ilícitos ou cada vez mais degradantes.

Sendo excluídos socialmente, estes indivíduos, que têm a mesma necessidade de manutenção da vida que qualquer outro, acabam encontrando a inserção social no ambiente ilícito e criminoso, pelo tráfico e pelo crime organizado, onde alcançam, ao menos aparentemente, alicerces para melhora imediata de sua condição de vida ${ }^{49}$, ainda que os exponha cruelmente a riscos elevados, muitas vezes fatais.

O ciclo então, pode se dar da seguinte maneira: trabalho degradante leva a condições precárias de trabalho e de vida, que por sua vez levam a pobreza/desigualdade social, que desagua na violência, inserindo esses indivíduos no sistema prisional, que, por conta do preconceito, quando saem da prisão, têm dificuldade de inserção no mercado de trabalho, sendo atingidos pelo desemprego, caminho para o trabalho degradante.

É claro que não se quer aqui tornar pueril e franciscana uma equação que não é exata. A pobreza e a desigualdade não são sinônimos de criminalidade, mas também é certo que as estatísticas demonstram que são fatores muito relevantes no panorama da violência. A idéia referenciada é também a aposta de Pires e Gatti (2006):

poucos de nós se questionam sobre qual parcela de responsabilidade nos é imputada neste sistema, neste círculo sem fim que se resume na falta de oportunidade (g.n.) > criminalidade > cumprimento de pena > liberdade > falta de oportunidade...

\footnotetext{
${ }^{49}$ Por óbvio que aqui não se pretende aduzir que o crime melhora a condição de vida do jovem, ao contrário, o empurra para a violência, mas o que se pretende é mostrar como o Estado se porta de modo ineficaz ao tentar inserir o jovem no mercado de trabalho, e este acaba sendo muitas vezes cooptado pelo crime organizado.
} 
Sabe-se que, em uma seleção de emprego, apesar de não ser obviamente esclarecido ao candidato, uma das primeiras averiguações que o selecionador realizará é a ficha criminal do candidato. Tendo sido ex-presidiário, por qualquer que seja o motivo, no mais das vezes acaba aí a chance deste candidato, mesmo sendo ele ex-detento, ou seja, tendo passado por todo projeto de punição e ressocialização estabelecido pelo Estado.

Parece ser bastante clara a ligação entre aumento de violência em meio a crises econômicas que refletem diretamente na empregabilidade. Apesar de não existir no Brasil estatísticas precisas e robustas sobre essa relação, muitos são seus pontos de fundamento.

Conforme pesquisa já referida no presídio de Maringá, constatou-se que os pais dos detentos tinham seus postos de trabalho especialmente em dois setores, a agricultura e a construção civil, dado bastante significativo na análise do binômio inserção social/trabalho.

Não é de se estranhar que tais setores estão entre os que promovem trabalhos mais degradantes, em condições de precariedade, sendo certo que o número de acidentes de trabalho em ambos são muito elevados.

Considere-se ainda que os dados oficiais, pode-se afirmar com margem de êxito, não trazem números reais, pois são computados a partir de dados alcançados no mercado formal de trabalho, ou seja, de trabalhos formalmente registrados. Porém, tanto na agricultura quanto na construção civil, é alto o índice de trabalhadores que, apesar de exercerem seus trabalhos com as características do emprego formal, não obtêm o registro na CTPS (Carteira de Trabalho e Previdência Social).

Destarte, é permitida a conclusão de que os números são muito superiores aos indicados oficialmente, ou seja, que estes dois setores da economia realmente se destacam na apresentação de péssimas condições de trabalho, especialmente no que tange à segurança do trabalhador, além do que demonstram os dados oficiais.

É de se supor, desta forma, que um dos problemas que contribui para a exclusão social é a falta de registro do contrato de trabalho, um dos elementos de precarização, que além das consequências mais óbvias, como o afastamento desse trabalhador da seguridade social - já que o indivíduo que mal ganha para sua vivência, não irá se inscrever voluntariamente no sistema de seguridade social $^{50}$ - induz a um erro estatístico para formulação de políticas públicas de emprego ou mesmo como dado importante para uma

\footnotetext{
${ }^{50}$ Ainda que, na realidade, sendo de fato empregado, mesmo sem o registro, poderá pleiteá-lo frente ao órgão competente, e garantir-se como segurado, muitos trabalhadores deixam de contar com os benefícios da seguridade social ou porque não buscam efetivar o reconhecimento de vínculo ou porque, mesmo que não seja a situação jurídica ideal, não se inscrevem sequer como autônomos ou facultativos perante o sistema.
} 
eventual alteração legislativa, porque este trabalhador não existe oficialmente. Mas já se salientou que é a desigualdade social o fermento que leva à violência e a alimenta. Mas a formalidade no trabalho em si não proporciona o trabalho decente.

Os dados alçados sobre exclusão social, trabalho e violência comportam a conclusão de que o desemprego e a precarização do trabalho são causas determinantes de exclusão social, ainda que não únicas.

A desigualdade, por sua vez, é um dos fatores que conduz à exclusão social, mostrando sua face diuturnamente das relações precárias de trabalho. Uma dos maiores fenômenos que levam à precarização do trabalho no Brasil é a terceirização de mão de obra. A terceirização torna o trabalho precário e degradante, mesmo contando com a formalidade de registro da CTPS. Acredita-se que este dado pode influenciar as estatísticas até então demonstradas, revelando um cenário pior do que o por elas indicado. Expliquese.

A relação entre trabalho degradante, desigualdade e exclusão resta exposta. Parece ser seguro afirmar que a desigualdade, como já se salientou aqui inúmeras vezes, é fator determinante que leva à violência. Também é cediço que a precarização do trabalho é elemento que concorre para a desigualdade, daí porque a discussão sobre o tema é fundamental, pois não basta meramente criar postos de trabalho, ou formalizar o vínculo empregatício para que o trabalho se torne decente.

Se a ferida que a terceirização causa na luta pela igualdade social não for exposta e debatida, poder-se-á desviar a implementação política necessária e maquiar os dados elementares. Senão vejamos.

Uma discussão que não se mostra destacada em nenhuma das estatísticas ou dados estudados, é a que os percentuais de emprego formal certamente contam, para engordá-los, com os registros de trabalho realizados pelas empresas intermediárias ou terceirizantes, que emprestam a mão-de-obra de seus empregados, via contrato de prestação de serviços, às empresas tomadoras de serviços.

Apesar da esquizofrênica forma de contratação que é a terceirização (quem toma o serviço não tem poder diretivo sobre o empregado), e de reduzir drasticamente a dignidade do trabalhador porque é forma de precarização do trabalho, ela elenca o rol de empregos formais. E essa informação é altamente relevante porque a desigualdade de condições é materializada nesse tipo de relação jurídica, e sua inobservância pode levar à falsa impressão de que a mera formalização do emprego, por si, transforma essa contratação em trabalho decente e promove a igualdade social. 
Se as estatísticas forem consideradas para fins de efetividade do trabalho decente e de inclusão social, a leitura viciada dos dados pode acarretar imensa mácula a esta iniciativa. Primeiro, porque, mesmo quando a terceirização é ilícita, no sentido de que a tomadora de serviços é quem realmente detêm o poder diretivo, se ainda não tiver sido constatada a irregularidade pela Justiça do Trabalho ou pela fiscalização do MPT ou do Ministério do Trabalho, constará essa relação nos índices de trabalhos regulares e formais; mais que isso, como aludido, embusteará qualquer ação governamental, porque uma relação de trabalho terceirizado jamais poderá ser parte de uma política de inclusão, pois é recheada de fatores que desigualam o trabalhador e o levam para a vida indigna.

Já foi demonstrado que uma das facetas mais cruéis da terceirização é a nova tendência (talvez nem tão nova assim...) de empurrar o trabalhador terceirizado para a realização das funções mais desgastantes e perigosas, o que torna a terceirização fator sério de risco para a saúde. Novamente, a dignidade do trabalhador é atacada e o terceirizado é também por este prisma atingido pela desigualdade.

Não é outra a conclusão que se chega. Pesquisa realizada na área de saúde alerta sobre a falta de dados acerca de como fenômenos como a globalização ${ }^{51}$ interferem na saúde - inclusive pública - pois os trabalhos omitem a relação entre doença e o contexto onde as pessoas doentes estão inseridas, como desemprego, trabalho com agrotóxicos, etc:

Os referenciais selecionados como base para nosso estudo ainda possuem uma penetração limitada quando se pretende contextualizar famílias e saúde, os trabalhos apresentados em periódicos de Saúde Pública e Saúde Coletiva do Brasil e do exterior trazem reflexões em torno dos graves problemas de saúde que estão associadas às temáticas dedicadas ao meio ambiente, desastres naturais e estruturais no mundo, as discussões sobre riscos quase sempre estão associadas ao conceito de vulnerabilidades. A limitação destes referenciais teóricos e metodológicos reflete a nossa inexperiência em discutir o processo saúde e doença em uma perspectiva mais abrangente e integral. Talvez isto explique a relativa omissão de nossas pesquisas sobre a saúde das populações com os temas que relacionem as doenças aos contextos ambientais poluídos, envenenamento de alimentos por agrotóxicos, liberação de manipulação de produtos químicos nas lavouras sem testes conclusivos sobre riscos à

\footnotetext{
${ }^{51}$ Que, como a terceirização, precariza o exercício da mão-de-obra, daí porque a informação se aproveita.
} 
vida humana, desemprego, solidão e imigração, por exemplo. Estudos científicos a que temos acesso discutem muito pouco sobre a globalização mundial e a sua interdependência com os agravamentos da saúde humana em função dos riscos que passamos a conviver diariamente, por causa da negação de oportunidades e opções básicas para o desenvolvimento humano e uma vida criativa decente. Para alguns pesquisadores, a globalização reflete possibilidades positivas para as nações em função do crescimento global que proporciona em termos de economia e geração de empregos. Entretanto, raramente, com algumas exceções, nos deparamos com uma reflexão mais crítica a respeito dos desníveis sociais criados e da manipulação de divisas econômicas, de modo que o custo de vida aumente e, conseqüentemente, a pobreza e as violências estruturais advindas das desigualdades sociais. Não que queiramos voltar a discussão sobre velhos argumentos que desprezam o capital econômico, as cremos que não é mais possível negar que os riscos potenciais à saúde ou qualquer outro nome que se queira dar as vulnerabilidades que o ser humano vivencia, estejam estreitamente relacionados ao que nos rodeia: terra, água, matas, pessoas e cultura material e imaterial. (PRÓSPERO et al., 2005)

Como ilustração de tal informação, pode-se estabelecer, por exemplo, uma ligação entre o dia a dia extenuante e pouco dignificante que um trabalhador - ou exposto à má condição de trabalho e remuneração ou à falta de um posto de trabalho- tem e o desenvolvimento de doenças que constam nas estatísticas de violência como elementos detonadores. A pressão exercida pelo mercado de trabalho perverso que se vê, pode não ser a causa determinante, mas certamente pode ser um dos fatores que desencadeia uma doença como o alcoolismo. Ilustrando, o trabalhador sai do local da prestação de serviços e, no caminho para casa, se embriaga. A pressão que ele sofreu no dia é extravasada pelo álcool, que dá vazão ao repasse da violência que sofreu, sendo um dos fatores que geram ou agravam a violência doméstica, a violência no trânsito, os crimes cometidos de forma passional, dentre outros, conforme estatísticas (JORGE, 2001):

\section{Algumas estatísticas sobre o álcool}

O alcoolismo acomete de $10 \%$ a $12 \%$ da população mundial e $11,2 \%$ dos brasileiros que vivem nas 107 maiores cidades do país A incidência de alcoolismo é maior entre os homens do que entre as 
mulheres

A incidência do alcoolismo é maior entre os mais jovens, especialmente na faixa etária dos 18 aos 29 anos, reduzindo com a idade

A álcool é responsável por cerca de $\mathbf{6 0 \%}$ dos acidentes de trânsito e aparece em $70 \%$ dos laudos cadavéricos das mortes violentas

De acordo com a última pesquisa realizada pelo Centro Brasileiro de Informações sobre Drogas Psicotrópicas (CEBRID) entre estudantes do $1^{\circ}$ e $2^{\circ}$ graus de dez capitais brasileiras, as bebidas alcoólicas são consumidas por mais de $65 \%$ dos entrevistados, estando bem à frente do tabaco. Dentre esses, $50 \%$ iniciaram o uso entre os 10 e 12 anos de idade. Então por isso proibirão venda de álcool a menores de 16 anos.

Uma pesquisa da Associação Brasileira de Psiquiatria, sobre a síndrome de abstinência de álcool (SAA) ${ }^{52}$, demonstra que, quando a SAA encontra-se em grau I, menos severo, o indivíduo consegue ainda manter uma atividade produtiva moderada, ainda que esteja desempregado, e, quando ela se manifesta em grau II, mais severo, o indivíduo já não consegue manter atividade produtiva, nem mesmo informalmente, ou seja, está desempregado e sem nenhum outro tipo de trabalho.

Esses dados são importantes, por dois aspectos, em relação ao trabalho proposto. Numa primeira perspectiva, pode-se bem pressupor, como já analisado, que um ambiente prejudicial de trabalho ou o desemprego podem conduzir um indivíduo, mesmo em se considerando que ele seja predisposto, às doenças psiquiátricas e psicológicas, como a dependência química.

Em uma outra perspectiva, o sujeito que está empregado e tem a doença, ou manifesta a doença que até então estava controlada; assim que tal fato ocorre, normalmente, é dispensado, mesmo que sem justa causa. Ora, o próprio Código Civil, em seu artigo $4^{\circ}$, prevê a embriaguez habitual como doença:

Art. $4^{0}$ São incapazes, relativamente a certos atos, ou à maneira de os exercer:

II - os ébrios habituais, os viciados em tóxicos, e os que, por deficiência mental, tenham o discernimento reduzido;

\footnotetext{
${ }^{52}$ A síndrome de abstinência do álcool é um quadro que aparece pela redução ou parada brusca da ingestão de bebidas alcoólicas após um período de consumo crônico. A síndrome tem início 6-8 horas após a parada da ingestão de álcool, sendo caracterizada pelo tremor das mãos, acompanhado de distúrbios gastrointestinais, distúrbios de sono e um estado de inquietação geral (abstinência leve). Cerca de 5\% dos que entram em abstinência leve evoluem para a síndrome de abstinência severa ou "delirium tremens" que, além da acentuação dos sinais e sintomas acima referidos, caracteriza-se por tremores generalizados, agitação intensa e desorientação no tempo e espaço. (UNIFESP)
} 
O que normalmente ocorre com essas duas perspectivas é uma intersecção. O individuo é dispensado de seu trabalho. Se o trabalho não for da espécie emprego, pior ainda, porque se ele não foi prevenido e não se filiou à Seguridade Social, não terá qualquer tipo de benefício social ${ }^{53}$. Diante da situação ou do desemprego, ou de subemprego, o alcoólatra possivelmente tem seu quadro de saúde piorado, pois a pressão que sofre pela falta de garantia de sua subsistência e por más condições de trabalho é claro que afeta substancialmente sua condição. Se sua condição de saúde ainda permite, vai em busca de outro posto de trabalho, que lhe será negado se no processo de seleção sua doença for descoberta.

O que se pode perceber é que, mesmo sendo a embriaguez habitual considerada doença para o Código Civil, na CLT ainda é tratada como causa de dispensa justificada, conforme se depreende do artigo 482:

Art. 482. Constituem justa causa para rescisão do contrato de trabalho pelo empregador:

f) embriaguez habitual ou em serviço (g.n.);

A exclusão social do alcoólatra, no que se refere ao trabalho, é dupla, tanto para manter o emprego quanto para obter novo posto de trabalho, ou seja, tanto gera o desemprego como mantém o indivíduo no desemprego ou no trabalho precário. No entanto, na perspectiva do trabalho decente, pode-se dizer mesmo na perspectiva legal, o alcoólatra deveria ser afastado com benefício da previdência social por motivo de doença, como são aqueles que sofrem de males menos discriminados socialmente, e não dispensado, mesmo que o seja sem justo motivo. Essa seria a forma legal de tratamento ao doente por embriaguez habitual, que consagra a igualdade de tratamento e, por conseqüência, a inclusão social.

A psicologia informa diversas motivações que fundamentam a relação entre trabalho degradante, desemprego, doença e violência. Os estudiosos ${ }^{54}$ sobre o tema indicam que a pressão sofrida no trabalho degradante pode não ser exatamente causa exclusiva dos distúrbios psicológicos que sofrem os indivíduos, mas, no mínimo, pode ser o elemento catalisador de uma doença. O que significa dizer que o trabalho degradante é, nessa perspectiva, um dos elementos que detonam a violência (HELOANI, CAPITÃO; 2003).

\footnotetext{
${ }^{53}$ Salvo aqui, talvez, a hipótese do benefício da LOAS.

${ }^{54}$ Cf. em $<$ http://www.scielo.br/pdf/spp/v17n2/a11v17n2.pdf $>$.
} 
Essas informações levam a crer que a inclusão social por meio do trabalho se dá, na verdade, com o trabalho decente, já que as estatísticas demonstram que não é exatamente a pobreza que induz ao crime, mas sim a desigualdade. O trabalho decente certamente é instrumento eficaz contra a desigualdade e, via de conseqüência, elemento que promove a igualdade entre as pessoas, promovendo assim a inclusão social.

Se o homem passa a maior parte de seu tempo trabalhando, suas relações pessoais fora de casa deveriam ter um valor afetivo de extrema importância. No entanto, as relações de companheirismo e de amizade no trabalho não se concretizam, pois elas são passageiras, imediatas, competitivas e as ligações afetivas, os vínculos não podem estabelecer-se, já que com cada alteração rompem-se os laços, perdem-se as pessoas e daí, além do castigo do desemprego, há a solidão, a perda irreparável. Fala-se em corrosão do caráter porque ninguém, nem os que teriam todas as razões para estarem satisfeitos com o sistema já que representam seu próprio ideal, encara seu emprego num horizonte a longo prazo. $\mathrm{O}$ comportamento de curto prazo, como Sennett (1998) observou, distorceu qualquer senso de realidade, confiança e comprometimento mútuo. As empresas descartam seus funcionários e os que podem fazem o mesmo. As pessoas parecem não mais estarem preocupadas com o significado do seu trabalho ou com a oportunidade de vivência e troca coletiva. A preocupação volta-se para a acumulação de um valor de troca, como se todos se convertessem em uma ação de mercado, cujo preço é julgado por outrem. A verdadeira identificação com o trabalho parece viver de um objetivo que não chega a concretizar-se: acumula-se aprendizado, dinheiro, experiência, aumentam-se as páginas do currículo, tudo para o próximo processo seletivo já que o trabalho atual será apenas momentâneo. (HELOANI, CAPITÃO, 2003)

Destarte, se permite, pelas questões abraçadas, identificar que o trabalho degradante, como em um ciclo retroalimentador, não apenas propele o trabalhador a uma situação de desigualdade, na medida em que ele não atinge os bens da vida que permitam a ele ser igual materialmente, mas também o conserva nesta condição. 
Note-se que, neste aspecto, o conceito da OIT permite adjetivar como decente o trabalho atribuído a um jovem, sem a proteção mínima instituída pelos princípios de Direito do Trabalho, como no caso do Projeto Jovem Cidadão instituído pelo Governo de São Paulo pelo Decreto Estadual n $n^{\circ} 44.860$, que permite o trabalho de pessoas entre 16 e 21 anos, por quatro horas diárias e cinco dias da semana por um valor mínimo de $\mathrm{R} \$ 130,00$, como estagiário ${ }^{55}$, porquanto teoricamente induz a um trabalho produtivo, remunerado adequadamente por se tratar de oportunidade de inserção no mercado de trabalho e aprendizagem profissional, exercido livremente, com segurança (a lei até mesmo exige a instituição de seguro de acidente pessoal e de vida...).

Claramente este exemplo indica como o trabalho que não é da espécie emprego estimula a desigualdade e oferece ao capitalista oportunidade de manter legalmente mãode-obra a um custo baixíssimo e à margem da segurança legal.

Todos os apontamentos aqui realizados têm por objetivo incrementar o debate sobre a importância do trabalho decente como instrumento de inclusão social, pois o indivíduo, no mais das vezes, obtém sua vivência a partir do trabalho remunerado, ou seja, obtém renda a partir do trabalho.

Quando atingido pela desigualdade material, o trabalhador não consegue alcançar os bens da vida a partir do rendimento que obtém do trabalho, nem tem no ambiente laboral espaço de socialização, daí porque acaba atingido pela exclusão social. Daí porque todos os debates suscitados corroboram para a criação de um conceito mais efetivo de trabalho decente.

\footnotetext{
${ }^{55}$ Desvirtuando totalmente a noção de estágio, que sempre indicou a realização de atividades práticas coerentes com teorias profissionalizantes estudadas no ensino médio profissionalizante e nos cursos superiores de graduação, na esteira do que fez a nova Lei de Estágio, de nº 11.788/08.
} 


\section{TRABALHO DECENTE À LUZ DA ORGANIZAÇÃO INTERNACIONAL DO TRABALHO}

O vertente estudo tem o escopo de buscar o aprimoramento do conceito de trabalho decente produzido pela OIT, trazendo-lhe maior eficácia.

No entanto, necessário o reconhecimento da importância do trabalho produzido pelo organismo, pois, até a iniciativa da instituição de tomar para si a hercúlea tarefa, não havia uma definição de trabalho decente, apesar de a temática ser muito suscitada nos meios acadêmico, político e social.

É de se destacar, assim, a relevância da atuação da OIT porque foi precursora na conceituação do termo trabalho decente, ato que deflagrou propostas não apenas de estudo acadêmico do tema, mas de oferecimento de planos políticos de promoção da dignidade do trabalhador.

Sem receio de errar, pode-se afirmar que a OIT é hoje o maior produtora de doutrinas, estatísticas e outras informações sobre trabalho decente, tendo se tornado, destarte, um dos grandes centros de referência sobre o assunto, produzindo valiosas fontes de informação.

Daí porque, sendo a OIT um organismo internacional poderoso, e tendo se tornado a maior referência sobre o assunto, seu conceito de trabalho decente, os pilares em que se fundam e a interpretação dada por seus doutrinadores se projetam mundialmente, impactando nas ações que concretizam e tornam eficaz a dignidade do trabalhador.

Por isso, qualquer movimento da OIT deve ser objeto de muito debate e planejamento, nos mais diversos níveis, ou seja, na Academia, nos órgãos estatais, na sociedade civil organizada, porque suas ações repercutem imensamente, tendo o condão de promover ou dificultar a eficácia do conceito de trabalho decente, e, quer-se crer que esta é uma das contribuições deste estudo, na medida em que não se nega à discussão, apresentando críticas e novas possibilidades referentes ao tema, o fazendo com a única intenção de contribuir na tarefa iniciada pela OIT de difundir e promover o conceito de trabalho decente, buscando assim dar maior eficácia na construção e solidificação da dignidade do trabalhador. 


\subsection{O conceito de trabalho decente na OIT}

Para a OIT, o trabalho decente pode ser conceituado como "trabalho produtivo e adequadamente remunerado, exercido por homens e mulheres de todo o mundo em condições de liberdade, igualdade, segurança e dignidade, e livre de qualquer forma de discriminação ${ }^{56 "}$. Esse conceito de trabalho decente é estruturado em quatro objetivos estratégicos indicados pelo órgão, a saber: a promoção dos direitos fundamentais no trabalho; o emprego; a proteção social e fortalecimento do tripartismo e do diálogo social.

A denominação utilizada pelo órgão é passível de questionamentos, já que trabalho decente pode ensejar uma interpretação baseada em questões morais, como no caso do trabalho das prostitutas, que pode ser indecente pelas más condições em que é exercido e não pela consideração moral que normalmente lhe é atribuída; mas, é certo que tal caracterização se difundiu mundialmente, e, apesar das críticas que possa suscitar, ao mesmo tempo não se pode deixar de reconhecer a força universal do termo.

Para que essa definição possa ser melhor contextualizada dentro da instituição, importa especificar a normatização sistematizada sobre o tema pela OIT.

Deve-se considerar que a Organização Internacional do Trabalho (OIT), como agência da ONU (Organização das Nações Unidas), está adstrita a seus princípios, normas e orientações, daí porque o estudo se inicia a partir do posicionamento do tema trabalho na ONU, para então considerar a ótica da OIT sobre a proposição.

A importância social do trabalho é tamanha que elenca o rol de Direitos Fundamentais da Pessoa Humana. É o que se confirma no artigo 23 da Declaração Universal dos Direitos Humanos da ONU, datada de 1948:

I) Todo o homem tem direito ao trabalho, à livre escolha de emprego, a condições justas e favoráveis de trabalho e à proteção contra o desemprego.

II) Todo o homem, sem qualquer distinção, tem direito a igual remuneração por igual trabalho.

\footnotetext{
${ }^{56}$ Cf. Memorial proferido por Juan Somavia na $87^{\mathrm{a}}$ Reunião, em Genebra, no mês de junho de 1999 , onde se vê o conceito de trabalho decente e os pilares em que está estabelecido.
} 
III) Todo o homem que trabalha tem direito a uma remuneração justa e satisfatória, que lhe assegure, assim como a sua família, uma existência compatível com a dignidade humana, e a que se acrescentarão, se necessário, outros meios de proteção social.

IV) Todo o homem tem direito a organizar sindicatos e a neles ingressar para proteção de seus interesses.

A referida Declaração já traz indícios de que trabalho, inserido no contexto da realidade sócio-jurídica, tem o sentido específico de trabalho decente, como demonstra quando fala em "livre escolha, condições justas e favoráveis e em proteção contra desemprego".

A Organização Internacional do Trabalho (OIT) observa os parâmetros estabelecidos na aludida Declaração, como se denota do memorial que foi proferido por Juan Somavia - primeiro diretor geral da OIT proveniente do hemisfério sul - apresentado por ocasião da $87^{a}$ Reunião, em Genebra, no mês de junho de 1999. Aduz Somavia que:

Conjuntamente, esos cuatro objetivos definen el modo en que la OIT puede promover la finalidad fundamental de un trabajo decente, que es sinónimo de trabajo productivo, en el cual se protegen los derechos, lo cual engendra ingresos adecuados con una protección social apropiada. Significa también un trabajo suficiente, en el sentido de que todos deberían tener pleno acceso a las oportunidades de obtención de ingresos. Marca una pauta para el desarrollo económico y social con arreglo a la cual pueden cuajar la realidad del empleo, los ingresos y la protección social sin menoscabo de las normas sociales y de los derechos de los trabajadores. Tanto el tripartismo como el diálogo social son objetivos por derecho propio, que garantizan la participación y la democracia y que contribuyen a la consecución de los demás objetivos estratégicos de la OIT (g.n.). La nueva economía mundial brinda oportunidades al alcance de todos, pero es preciso enraizarlas en unas instituciones sociales basadas en la 
participación, con objeto de conseguir la legitimación y la permanencia de las políticas económica y social. (SOMAVIA, 1999)

Esses quatros objetivos indicados por SOMAVIA (1999), pode-se afirmar, são, além de objetivos, bases fundantes do próprio conceito de trabalho decente.

Apesar desses quatro pilares propostos pela OIT para a efetivação do trabalho decente serem abrangentes a ponto de dificultar a eficácia do conceito, não devem ser descartados haja vista que são importantes indicativos em relação a dignidade do trabalhador, contando, para tanto, com boa técnica de exegese, que poderá suprir divergências conceituais falaciosas, a partir especialmente dos princípios basilares do direito do trabalho.

Sendo assim, uma interpretação realizada a partir dos aludidos princípios de direito do trabalho, efetuada ainda com base na teoria constitucional, pode ter o condão de promover um conceito de trabalho decente que lhe propicie maior efetividade.

Portanto, quanto mais objetiva for essa conceituação, mais possível se torna a concretização do trabalho decente, e, no universo jurídico, se torna de mais fácil aplicabilidade e exigibilidade ${ }^{57}$.

SOMAVIA (1999), no mesmo documento, ainda traz elementos que auxiliam na definição do termo trabalho decente pela OIT:

La OIT milita por un trabajo decente. No se trata simplemente de crear puestos de trabajo, sino que han de ser de una calidad aceptable. No cabe disociar la cantidad del empleo de su calidad. Todas las sociedades tienen su propia idea de lo que es un trabajo decente, pero la calidad del empleo puede querer decir muchas cosas. Puede referirse a formas de trabajo diferentes, y también a muy diversas condiciones de trabajo, así como a conceptos de valor y satisfacción. Hoy en día, es indispensable crear unos sistemas económicos y sociales que garanticen el empleo y la seguridad, a la vez que son capaces de adaptarse a unas circunstancias en rápida evolución, en un mercado mundial muy competitivo.

\footnotetext{
${ }^{57}$ Não se quer aqui, sublinhe-se, afirmar que se entende que os direitos humanos, ou direitos fundamentais inseridos na constituição deixam de ser imediatamente aplicáveis, mas apenas que tal discussão já se afasta de pronto, que se parte da convicção da plena aplicabilidade de todas as normas constitucionais.
} 
SOMAVIA identifica e associa trabalho decente com a criação de postos de trabalho com qualidade aceitável. Resta que seja esclarecido o que é qualidade aceitável em um posto de trabalho, se essa definição é flexível diante da diversidade material e cultural entre os países, ou se há um núcleo duro nessa definição.

A própria Constituição da OIT (1946), especialmente em seu preâmbulo, estabelece alguns parâmetros que podem pautar a adequação do conceito de trabalho decente instituído pela instituição:

Considerando que existem condições de trabalho que implicam, para grande número de indivíduos, miséria e privações, e que o descontentamento que daí decorre põe em perigo a paz e a harmonia universais, e considerando que é urgente melhorar essas condições no que se refere, por exemplo, à regulamentação das horas de trabalho, à fixação de uma duração máxima do dia e da semana de trabalho, ao recrutamento da mão-de-obra, à luta contra o desemprego, à garantia de um salário que assegure condições de existência convenientes, à proteção dos trabalhadores contra as moléstias graves ou profissionais e os acidentes do trabalho, à proteção das crianças, dos adolescentes e das mulheres, às pensões de velhice e de invalidez, à defesa dos interesses dos trabalhadores empregados no estrangeiro, à afirmação do princípio "para igual trabalho, mesmo salário", à afirmação do princípio de liberdade sindical, à organização do ensino profissional e técnico, e outras medidas análogas $(\ldots)$

Note-se que cada exemplo do que representaria as condições convenientes indicados no preâmbulo correspondem em enorme medida aos itens de proteção legal do trabalhador empregado, subordinado, que presta trabalho com pessoalidade, habitualidade e onerosidade.

A Declaração de Filadélfia (1944) também estabelece balizas na interpretação do conceito de trabalho decente estabelecido pela OIT. Indica como princípio fundamental na 
qual "repousa a Organização" que o trabalho não é mercadoria (g.n.); que a experiência demonstra ser sobre a justiça social que a paz se assenta ${ }^{58}$.

A Conferência Geral da OIT, na referida Declaração, afirma que todos os seres humanos de qualquer raça, crença ou sexo, têm o direito de assegurar o bem-estar material e o desenvolvimento espiritual dentro da liberdade e da dignidade, da tranqüilidade econômica e com as mesmas possibilidades, e que a realização de condições que permitam o exercício de tal direito deve constituir o principal objetivo de qualquer política nacional ou internacional, indicando ainda que qualquer plano ou medida, especialmente os econômicos e financeiros, devem ser considerados sob esse ponto de vista e somente aceitos, quando favorecerem, e não entravarem, a realização desse objetivo principal (g.n.).

Muito significativos são esses indicativos, especialmente ao se observar a recomendação de que planos e medidas econômicas e financeiras devem ser aceitas somente na medida em que promovem a justiça social. Note-se que o documento referido não estabelece que tais planos e medidas são apenas aqueles advindos do Estado, com o que se conclui que se referem também aos particulares ou privados, ampliando destarte a importância deste parâmetro.

A Conferência indica ainda que a OIT tem obrigação de auxiliar na execução de programas que, dentre outras coisas, visem proporcionar emprego integral para todos e elevar os níveis de vida, e, especialmente, adotar normas referentes aos salários e às remunerações, ao horário e às outras condições de trabalho, a fim de permitir que todos usufruam do progresso. Além disso, são enumeradas outros institutos que devem igualmente serem promovidos pela OIT, como ampliar as medidas de segurança social, a fim de assegurar tanto uma renda mínima e essencial a todos a quem tal proteção é necessária, a exemplo de assistência médica completa; assegurar uma proteção adequada da vida e da saúde dos trabalhadores em todas as ocupações; garantir a proteção da infância e da maternidade; obter um nível adequado de alimentação, de alojamento, de recreação e de cultura, dentre outros.

De forma reincidente, a OIT enumera elementos que moldam o trabalho que, de forma geral, pode conduzir ao ideal de justiça social, e, mais uma vez, pode-se perceber de

\footnotetext{
${ }^{58}$ Naquele momento histórico, visto que a Declaração da Filadélfia foi instituída em 1944, apenas 1 ano antes do final da segunda guerra mundial, a idéia de paz e justiça social encontrava fértil terreno diante das horrendas experiências que trouxe esta luta armada.
} 
forma cristalina que esses itens são aqueles eleitos pelo Direito do Trabalho para garantir a proteção do trabalhador subordinado hipossuficiente, qual seja, o empregado.

A Convenção 122 da OIT, que trata de políticas de emprego e elevação do nível de vida, pode contribuir sobremaneira para a formatação do conceito de trabalho decente instituído por este órgão. Nas suas considerações iniciais, se refere a "pleno emprego", termo que leva à concepção de labor subordinado com condições de proteção do prestador de mão-de-obra hipossuficiente.

Esta Norma traz em seu corpo outros elementos que, unidos, moldam o conceito de trabalho decente, como a luta contra o desemprego - cristalizando, assim, a idéia de que o emprego é essencial ao bom desenvolvimento da vida social, já que é esta forma de contratação que estabelece a garantia de um salário que assegure condições de vida convenientes - o salário mínimo - o direito ao bem-estar material e espiritual, com liberdade e dignidade, a segurança econômica e igualdade de oportunidades.

Nas considerações preliminares da referida Convenção, são expostos os seguintes elementos objetivos na construção do conceito de trabalho decente:

Considerando que la Declaración de Filadelfia reconoce la obligación solemne de la Organización Internacional del Trabajo de fomentar, entre todas las naciones del mundo, programas que permitan lograr el pleno empleo y la elevación del nivel de vida (g.n.), y que en el preámbulo de la Constitución de la Organización Internacional del Trabajo se dispone la lucha contra el desempleo y la garantía de un salario vital adecuado (g.n.);

Considerando, además, que de acuerdo con la Declaración de Filadelfia incumbe a la Organización Internacional del Trabajo examinar y considerar los efectos de las políticas económicas y financieras sobre la política del empleo, teniendo en cuenta el objetivo fundamental de que todos los seres humanos, sin distinción de raza, credo o sexo, tienen derecho a perseguir su bienestar material y su desarrollo espiritual en condiciones de libertad y dignidad, de seguridad económica y en igualdad de oportunidades (g.n.);

Considerando que la Declaración Universal de Derechos Humanos dispone que toda persona tiene derecho al trabajo, a la libre 


\section{elección de su trabajo, a condiciones equitativas y satisfactorias} de trabajo y a la protección contra el desempleo (g.n.);

Teniendo en cuenta las disposiciones de los convenios y recomendaciones internacionales del trabajo en vigor relacionados directamente con la política del empleo, especialmente el Convenio y la Recomendación sobre el servicio del empleo, 1948; la Recomendación sobre la orientación profesional, 1949; la Recomendación sobre la formación profesional, 1962, así como el Convenio y la Recomendación sobre la discriminación (empleo y ocupación), 1958; Teniendo en cuenta que estos instrumentos deben ser considerados como parte integrante de un programa internacional más amplio de expansión económica basado en el pleno empleo, productivo y libremente elegido (g.n.); (OIT, 1964)

A Convenção 122 da OIT, ora examinada, recorrentemente indica a persecução do pleno emprego, posto que a "plenitude" se encontra na garantia legal de limites à autonomia privada, ou seja, na intervenção do Estado por meio do direito estabelecendo limites à exploração da mão-de-obra.

Não se pode imaginar que a conotação dada pela OIT ao termo se inspira unicamente na da teoria de Keynes (1982) acerca do pleno emprego, ou seja, de que todos os fatores disponíveis (capital, trabalho, recursos naturais) estão se desenvolvendo na sua máxima capacidade e, portanto, que todos os que desejam trabalhar têm garantida tal oportunidade, até porque a Entidade promove vários estudos que negam completamente que o mundo, inclusive o Brasil, esteja em tal nível de avanço ${ }^{59}$.

É de se observar ainda que a questão do pleno emprego como sinônimo de que não existe trabalhador ocioso involuntariamente deve ser sopesada com preceitos de direitos humanos, ou seja, que a garantia de trabalho por si não é necessariamente satisfatória, pois o pleno emprego deve conjugar valores de dignidade do trabalhador, como faz crer toda normatização da OIT. No Brasil, pode-se afirmar com segurança que a questão do pleno

\footnotetext{
${ }^{59}$ Existe uma tendência no país, conforme se depreende de entrevista concedida pelo Ministro do Trabalho e Emprego, Carlos Lupi à Guilherme Barros (2010), que acredita estar o Brasil próximo do pleno emprego, também observada por alguns economistas como Hélio Zylberstajn.
} 
emprego encontra-se engajada com ditames constitucionais também garantidores da dignidade do trabalhador.

Um segundo elemento da Convenção 122 que auxilia na formatação do sentido atribuído pela OIT para trabalho decente é a busca da elevação do nível de vida. Por elevação de nível de vida pode-se entender que o trabalho deve ser de tal monta que permita ao trabalhador sair da condição de vida em que se encontra para uma melhor condição. Apesar da aparente singeleza desta afirmação, este elemento se mostra dos mais fundamentais, haja vista que o trabalho que mantém o sujeito que o exerce em condições adversas à vida digna, ou, como nomeia a referida Convenção, não convenientes, não pode ser considerado decente.

O Documento, assim como o próprio preâmbulo da constituição da OIT, prevê a sua luta contra o desemprego e a garantia de um salário vital adequado, que assegure condições de vida convenientes.

A Convenção 122, na língua espanhola ${ }^{60}$, utiliza este termo "salário vital”, que, ao ser traduzido para a língua portuguesa, na aludida Convenção, ficou como "salário que assegure condições de vida convenientes. Essa digressão se impõe para salientar o significado da palavra vital, que, nos termos do dicionário Houaiss (2009), designa algo relativo à vida, essencial para a manutenção da vida. O que significa dizer que o salário tem natureza alimentar, trazendo, assim, efeitos muito significativos juridicamente, por exemplo, a possibilidade de, no direito nacional, obter penhora em rendimentos como vencimentos, o próprio salário, pensões, honorários, etc., devido a essa natureza de prestação alimentar, conforme exceção prevista no parágrafo $2^{\circ}$ do art. 649 do CPC, ou seja, de obter a penhora no salário, via de regra, quando a verba executada decorre de direito que também tem natureza alimentar como o salário, como pensões alimentícias.

A Convenção 122 estabelece que o acesso ao trabalho deva ser viabilizado a todos, sem qualquer tipo de discriminação, porque todos têm o direito ao bem estar material e espiritual, em condições de liberdade e dignidade, de seguridade econômica e igualdade de oportunidades.

Essas condições de liberdade e dignidade são melhor esclarecidas no tópico seguinte do mesmo documento, que indica que toda pessoa tem direito ao trabalho, à livre

\footnotetext{
${ }^{60}$ (...) Considerando que la Declaración de Filadelfia reconoce la obligación solemne de la Organización Internacional del Trabajo de fomentar, entre todas las naciones del mundo, programas que permitan lograr el pleno empleo y la elevación del nivel de vida, y que en el preámbulo de la Constitución de la Organización Internacional del Trabajo se dispone la lucha contra el desempleo y la garantía de un salario vital (g.n.) adecuado (...); In < http://www.ilo.org/ilolex/spanish/convdisp1.htm>.
} 
(g.n.) escolha de seu trabalho, a condições equitativas e satisfatórias, e à proteção contra o desemprego.

Já se indicou que a OIT, constantemente, cultiva a expressão pleno emprego ${ }^{61}$, demonstrando assim como esta idéia se propaga dentro da temática trabalho decente. A Convenção 150 sobre administração do trabalho reforça esse entendimento, quando novamente alude ao pleno emprego como um objetivo.

\subsection{Os quatros pilares do conceito de trabalho decente segundo a OIT}

Como já anteriormente citado, SOMAVIA (1999), em seu memorial da $87^{\mathrm{a}}$ Conferência Internacional da OIT, não apenas inovou ao estabelecer um conceito de trabalho decente como indicou os quatro objetivos perseguidos ao se tratar do termo, a saber, a promoção dos direitos fundamentais no trabalho; o emprego; a proteção social e fortalecimento do tripartismo e do diálogo social, que seguirão em análise.

\subsubsection{A promoção dos direitos fundamentais no trabalho}

A persecução estabelecida no primeiro objetivo do trabalho decente é a promoção dos Direitos Fundamentais no trabalho. Assim, mister que seja especificado o significado do termo, e apresentadas as divergências terminológicas para identificação do fenômeno.

Para parcela da doutrina humanista, o termo Direitos Humanos seria genericamente utilizado para se referir aos direitos que garantam a dignidade humana, e os termos Direitos e Garantias Fundamentais seriam utilizados para se referir aos Diretos Humanos já positivados e suas garantias de proteção ${ }^{62}$.

Ingo Sarlet (2001) afirma que a terminologia "Direitos Humanos Fundamentais", abrange "as esferas nacional e internacional de positivação", alegando que é a

\footnotetext{
${ }^{61}$ Quer-se crer, com uma concepção maior do que a Keynesiana, baseada nos Direitos Fundamentais da Pessoa Humana.

${ }^{62}$ Cf. Antonio E. Perez LÛNO, Los derechos fundamentales, p. 44 e seguintes sobre o tema.
} 
"fundamentalidade na sua perspectiva formal - que se encontra intimamente ligada ao direito constitucional positivo - que irá, em última análise, distinguir os direitos fundamentais constitucionais ${ }^{63}$ ".

O referido Autor (2009) ainda distingue os termos Direitos Humanos, estes referentes aos direitos elencados em documentos internacionais, e Direitos Fundamentais, estes referentes aos direitos "reconhecidos e positivados na esfera do Direito Constitucional positivo de determinado Estado ${ }^{64 \%}$.

José Afonso da Silva (1996, p. 182) conceitua que:

Os direitos fundamentais do homem constituem a expressão mais adequada a este estudo, porque, além de referir-se a princípios que resumem a concepção do mundo e informam a ideologia política de cada ordenamento jurídico, é reservada para designar, no nível do direito positivo, aquelas prerrogativas e instituições que ele concretiza em garantias de uma convivência digna, livre e igual de todas as pessoas.

No entanto, acreditamos que distinguir tais termos seria a negação das características essenciais dos Direitos Humanos, porque estes independem de qualquer positivação, e continuam fundamentais, porque sem a garantia desse rol o ser humano não encontra a vivência digna, por vezes apenas a sobrevivência ou, em linha indicativa, a negação da vida, que é a morte.

Muitas vezes, observe-se, que tais termos são utilizados, não só nas doutrinas sobre o tema, mas também nos textos normativos, como sinônimos, como no caso da Constituição Federal de 1988, que utiliza diversas terminologias ao tratar do mesmo tema ${ }^{65}$.

${ }^{63}$ Cf. em http://www.direitopublico.com.br/pdf/REVISTA-DIALOGO-JURIDICO-01-2001-INGOSARLET.pdf em 19.01.06.

${ }^{64}$ SARLET, em seu livro A eficácia dos direitos fundamentais (2009, p. 27 e seguintes), traz importante debate sobre a questão terminológica e a utilização de diversas expressões como Direitos Humanos, Direitos e Garantias Fundamentais, Direitos do Homem, etc., identificando as posições doutrinárias mais importantes sobre o assunto sendo certo que não há unanimidade na doutrina sobre tais termos serem sinônimos ou distinguirem fenômenos diferentes. O Autor ainda indica sua preferência pela terminologia Direitos Fundamentais, como se identifica no título de seu trabalho.

${ }^{65}$ Cf. SARLET, 2009, p. 27 e seguintes. 
Crê-se aqui na sinonímia dos termos, ainda que sejam justificáveis as doutrinas que os distinguem. Entende-se sobre essa questão terminológica como Jorge Miranda (1988, p. 9) quando afirma que:

(...) admitir que direitos fundamentais fossem em cada ordenamento aqueles direitos que a sua Constituição, expressão de certo e determinado regime político, como tais definisse seria o mesmo que admitir a não consagração, a consagração insuficiente ou violação reiterada de direitos como direito à vida, à liberdade de crenças ou à participação na vida pública só porque de menor importância ou desprezíveis para qualquer regime político; e a experiência, sobretudo na Europa nos anos 30 e 40 deste século, aí estaria a mostrar os perigos advenientes dessa maneira de ver as coisas.

Nesta mesma toada se posiciona João Caupers (1985), já que não admite qualquer distinção entre os termos analisados. Ademais, aqui se crê também que o conceito de Direitos Humanos exige um enfrentamento muito mais amplo do que a mera análise da identidade ou não desses termos.

A maior dificuldade na conceituação e definição dos Direitos Humanos se dá muito mais em torno de conteúdo do que da abrangência desse rol de direitos A maioria das doutrinas analisadas parece apontar a distinção dos termos usados para determinação da abrangência do termo (se positivados ou não, se, principalmente na diversidade e diferentes aspectos dos próprios direitos e de seus legitimados, ou seja, ainda que seja importante esse debate sobre a terminologia, o maior afrontamento se dá por conta do que contém o termo, ou seja, sua materialidade ou seu conteúdo, o que implica não apenas definição, mas também características e elementos que moldem essa conceituação).

No entanto, pode-se partir sempre de um ponto comum entre todo esse elenco: a proteção da vida humana com dignidade, que é a finalidade da proteção em torno da humanidade. Todas as gerações dos direitos humanos se convertem ao conceito de vida digna, é o que se pode concluir da idéia de Belisário dos Santos, quando este afirma que "de qualquer forma tais gerações só acrescentam atributos ao conceito de VIDA. Hoje, vida quer dizer VIDA LIVRE, DIGNA E SOLIDÁRIA”. 
Existe a necessidade de distinção entre a simples proteção da vida e a proteção da vida com dignidade. A vida resiste a condições não adequadas, limitando-se a manter em movimento todo o organismo humano, ainda que de modo debilitado; ou então, em outro mas não menos relevante aspecto, o ser humano pode ser mantido fisicamente vivo, ainda que mentalmente debilitado.

Certamente a proteção imaginada ao ser humano deve ser suficiente para mantê-lo vivo em condições adequadas de saúde física e mental, sempre havendo a remissão à vida digna, não somente à vida, de modo a não se permitir interpretação errônea de tal objetivo. O torturado pode resistir à morte, mas obviamente sofre grave violação do seu direito à vida digna, e, nesse sentido, não se pode imaginar que seus Direitos Humanos estão, com a superficial manutenção de sua vida orgânica, garantidos.

No que respeita ao objetivo ora debatido, a promoção dos direitos fundamentais no trabalho, acredita-se que o que se busca alcançar é a possibilidade de viver dignamente no trabalho e do trabalho.

Nessa toada, viver do trabalho significa que, a partir do desgaste da energia de um indivíduo na sua prestação de serviços ele atinge renda suficiente para viver dignamente.

A dignidade deve ser ainda vivenciada no trabalho, ou seja, o meio ambiente físico e psíquico oferecido ao trabalhador deve ser adequado. Destarte, o trabalho deve ser realizado em boas condições ambientais, que desgastem o mínimo possível o organismo do trabalhador, e da maneira mais suave possível, além de que o ambiente psíquico deve ser também voltado à preservação e manutenção das faculdades espirituais (psicológicas e psiquiátricas) do Obreiro.

Numa sociedade como a atual, que é fundada no trabalho como forma de sustentação prática da vida, ou seja, para obter os bens necessários para a subsistência, o trabalhador que se vê sem trabalho - mormente neste quadro atualmente apresentado de desemprego a nível mundial - também tem sua dignidade violada, com reflexos em todas as suas vertentes. No vertente estudo se sustenta a idéia de que o trabalho e o Direito do Trabalho (que regulamenta relações de emprego), na realidade, os Direitos Sociais, são instrumentos valiosos na concretização da vida digna.

Denota-se assim, que o sentido dos Direitos Fundamentais, em quaisquer de suas vertentes, conflui para a efetivação da vida digna, sendo assim inclusive no que respeita ao ser humano enquanto trabalhador, ou seja, a condição humana não pode e não deve ser afastada na exploração do trabalho, e, sob esse prisma, são os direitos fundamentais aqueles que devem ser promovidos e garantidos para a vivência digna no trabalho e do trabalho, 
sendo esta a finalidade da promoção dos Direitos Fundamentais como objetivo do trabalho decente.

\subsubsection{O emprego}

O segundo objetivo firmado pela OIT no que respeita ao trabalho decente é o emprego.

A própria OIT, ao desenvolver quais são as suas finalidades, especifica, como se vê do texto abaixo transcrito, que seu interesse se dá por qualquer tipo de trabalhador, não apenas o assalariado:

La OIT se interesa por todos los trabajadores. Debido a sus orígenes, la OIT ha centrado esencialmente su atención en las necesidades de los trabajadores asalariados - la mayoría de ellos de sexo masculino - en empresas del sector estructurado, pero no se agota con ello su mandato, ni tampoco el mundo del trabajo. Casi todas las personas trabajan, pero no todos tienen un puesto de trabajo. Abundan, además, en el mundo las personas que trabajan demasiado y las que están desempleadas. La OIT debe interesarse por quienes trabajan al margen del mercado de trabajo estructurado: asalariados no reglamentados, trabajadores por cuenta propia, trabajadores a domicilio. La participación del sector no estructurado en el volumen total del empleo ha llegado a casi el 60 por ciento en América Latina. En Africa, a la economía no estructurada le ha correspondido más del 90 por ciento de los nuevos puestos de trabajo urbanos en los diez años últimos. (SOMAVIA, 1999).

Assim, a primeira especificação que deve ser realizada nesta fração do estudo é que emprego para a OIT tem um significado muito mais abrangente do que a definição técnica que tem o termo no Direito do Trabalho brasileiro.

Emprego, espécie do gênero trabalho, na definição jurídica nacional significa o exercício de trabalho subordinado, submetido a um regramento legal específico previsto na CF/88, na Consolidação das Leis do Trabalho e demais diplomas legais. 
Para aquela Organização Internacional, o termo emprego é muito mais abrangente, e, como já se expôs aqui, não se limita ao trabalho subordinado, mas a outras formas de trabalho, como o trabalho exercido informalmente, o trabalho autônomo, etc.

A OIT destaca que, pela sua origem, naturalmente preponderou o interesse pelo trabalho subordinado, mas faz questão de destacar que, atualmente, mormente diante de um quadro social que sofreu, em curto lapso, mudanças profundas, marcadas por diversos fenômenos como a globalização, que impactaram fortemente no mundo do trabalho, e que essas outras formas que não sejam a de trabalho assalariado e subordinado devem ser igualmente contempladas pelo órgão.

É claro que, neste contexto, aqueles que não conseguiram obter trabalho, sendo ele assalariado e subordinado ou não, também merecem a atenção daquele organismo internacional, ou seja, o desemprego consta no seu rol de ocupação.

A OIT reconhece que, apesar de historicamente se voltar ao trabalhador subordinado, tem campo de interesse mais estendido, voltado a qualquer tipo de trabalho. No entanto, como se poderá depreender, ao tentar uma abrangência maior no campo de sua atuação, acaba por desproteger o trabalhador subordinado. $\mathrm{O}$ caminho que a civilização tem tomado, e, quer parecer, aquele organismo internacional também, é o oposto do que se esperava, porque, se o trabalho subordinado era protegido legalmente, o movimento que se tem visto não é o de inserir os trabalhadores não subordinados no campo legal de proteção dos empregados subordinados, mas, ao contrário, flexibilizar e desregulamentar as relações de trabalho subordinado, alçando os empregados para a desproteção que atingia as outras espécies de trabalho.

\subsubsection{Proteção social}

O terceiro objetivo voltado ao trabalho decente, segundo a OIT, é a proteção social desses trabalhadores.

Não há como desassociar proteção social de Estado do Bem-Estar Social (EBES), sendo que este é o promotor daquela, especialmente no que se refere à luta contra a pobreza, a doença e a exploração da mão-de-obra sem limites. 
POCHMANN (2004) dá conta de que o EBES "cumpriu distintas funções estratégicas, todas consagradas ao enfrentamento da pobreza, do desemprego e da desigualdade (g.n.)".

Muitos fatos contribuíram para o surgimento do EBES; no entanto, optou-se aqui por salientar apenas aqueles mais relevantes no que toca ao trabalho e defesa do trabalhador, tendo em vista que o estudo ora apresentado se volta ao estudo da proteção social dos trabalhadores como objetivo perseguido pelo trabalho decente.

A ameaça ao modelo liberal de estrutura capitalista, ocorrida pela incapacidade desse modelo de distribuir a riqueza obtida, gerando reação popular contra a pobreza e outros males sociais, culmina em uma forma de contenção desse anseio, que se conhece como Estado do Bem-Estar Social.

O Estado do Bem-Estar Social surge como instrumento de continuísmo da política liberal- capitalista, absorvendo, assim, a insatisfação social com os efeitos da aludida política ${ }^{66}$ e o avanço da doutrina comunista, tendo como essência a promoção, por parte do Estado, de benefícios de cunho social, com a criação de ordenamento jurídico e políticas públicas nesta direção.

Como alude François-Xavier Merrien, no seu L'État-providence:

La naissance de l'Etat-providence à la fin du XIXe, en réaction aux mutations sociales liées à la révolution industrielle, a constitué une rupture fondamentale dans la conception de l'Etat. L'Etat moderne, en prenant la relève des modèles antérieurs d'entraide, a acquis une nouvelle fonction : celle d'assurer un bien-être social aux citoyens par le biais de systèmes d'aides et de droits. Un siècle plus tard, la mondialisation oblige les puissances publiques à repenser les modalités de prise en charge des risques sociaux (vieillesse, invalidité, chômage). ${ }^{67}$.

Foram apontados dois elementos que instigaram o aparecimento EBES: a contenção do comunismo, que contou com o apoio da Igreja Católica e a criação de mecanismos (leis, políticas) de abrandamento da revolta social com a política liberal de acumulação desmedida de lucros.

\footnotetext{
${ }^{66}$ Essa insatisfação se dá pela incapacidade do capitalismo de manter a níveis baixos as taxas de desemprego, de distribuir de maneira mais equânime as riquezas, de afastar a pobreza, etc.

$67 \mathrm{O}$ nascimento do Estado de bem-estar no final do século XIX, em resposta às mudanças sociais relacionadas com a revolução industrial, foi uma mudança fundamental na concepção do Estado. O Estado moderno, assumindo a partir de modelos anteriores da assistência, adquiriu um novo objetivo: garantir o bem-estar social dos cidadãos através de sistemas de apoio e de direitos. Um século mais tarde, a globalização exige que os poderes públicos repensem as modalidades de gestão dos riscos sociais (velhice, invalidez, desemprego). (tradução nossa)
} 
A fim de conter a onda comunista que assolava o Hemisfério, a Igreja Católica passa a intervir na luta entre empregados e patrões, surgindo com a Encíclica Rerum Novarum, que emergiu como crítica à pregação comunista contra a propriedade privada e, portanto, no juízo dos papas, contra os ensinamentos de Jesus, já que a igreja pregava que o fruto do trabalho deveria ser usufruído pelo próprio trabalhador.

Essa Encíclica, juntamente com a Quadragésimo Anno, são documentos importantes ${ }^{68}$ na história da proteção social do trabalhador contextualizada na transição do Estado Liberal para o Estado do Bem-Estar Social, tendo em vista que defende a hipossuficiência do trabalhador, que, sabidamente, é uma premissa do Direito do Trabalho.

A idéia propagada era a de que a violação dos interesses da classe operária levaria à violação da própria justiça - pois a justiça deve dar a cada um o que é seu.

\begin{abstract}
Trabalhar é exercer a actividade com o fim de procurar o que requerem as diversas necessidades do homem, mas principalmente a sustentação da própria vida. 'Comerás o teu pão com o suor do teu rosto'. Eis a razão por que o trabalho recebeu da natureza como que um duplo cunho: é pessoal, porque a força activa é inerente à pessoa, e porque a propriedade daquele que a exerce e a recebeu para sua utilidade; e é necessário, porque o homem precisa da sua existência, e porque a deve conservar para obedecer às ordens incontestáveis da natureza. Ora, se não se encarar o trabalho senão pelo seu lado pessoal, não há dúvida de que o operário pode a seu bel-prazer restringir a taxa do salário. A mesma vontade que dá o trabalho pode contentar-se com uma pequena remuneração ou mesmo não exigir nenhuma. Mas já é outra coisa, se ao carácter de personalidade se juntar o de necessidade, que o pensamento pode abstrair, mas que na realidade não se pode separar. Efectivamente, conservar a existência é um dever imposto a todos os homens e ao qual se não podem subtrair sem crime. Deste dever nasce necessariamente o direito de procurar as coisas necessárias à subsistência, e que o pobre as não procure senão mediante o salário do seu trabalho. (VATICANO, 2010a)
\end{abstract}

Sendo a Igreja católica uma das maiores, senão a maior, proprietária privada do mundo, não é estranho que se posicionasse contrária às idéias comunistas, que, por sua vez, rechaçava a propriedade privada.

No entanto, ainda que outras motivações menos nobres a tenham gerado, a Encíclica traz importantes defesas referentes ao trabalhador inserido no mercado de trabalho liberal, como, por exemplo, o resguardo de um salário mínimo que lhe garanta a

\footnotetext{
${ }^{68}$ Não é objeto de discussão aprofundada, neste estudo, as motivações internas da Igreja Católica ao se posicionar contra o comunismo. Pontuou-se acerca dessa motivação para que o leitor possa situar o debate, mas não se pretende investigar minuciosamente esta questão.
} 
manutenção da vida com dignidade, além de, paradoxalmente, reconhecer a realidade concreta que empurra o trabalhador às péssimas condições de trabalho:

Façam, pois, o patrão e o operário todas as convenções que lhes aprouver, cheguem, inclusivamente, a acordar na cifra do salário: acima da sua livre vontade está uma lei de justiça natural, mais elevada e mais antiga, a saber, que o salário não deve ser insuficiente para assegurar a subsistência do operário sóbrio e honrado. Mas se, constrangido pela necessidade ou forçado pelo receio dum mal maior, aceita condições duras que por outro lado lhe não seria permitido recusar, porque lhe são impostas pelo patrão ou por quem faz oferta do trabalho, então é isto sofrer uma violência contra a qual a justiça protesta. (VATICANO, 2010a)

Para Pio XI, a violação da justiça se demonstrava na desigualdade na partilha dos bens do mundo, que não se resolvia pela caridade paliativa ${ }^{69}$, de onde se presume que a solução da questão social não se encontra somente na caridade, mas sim em sua conjugação com a justiça. Justiça é norma próxima das relações sociais, enquanto, ao invés, a injustiça é a degradação das relações humanas.

Antes mesmo da Encíclica Quadragésimo Anno, Pio XI utilizava a expressão justiça social. Em 05.06.1929, em carta dirigida à Monsier Liénart, Pio XI, louvando um consórcio têxtil pelas suas obras de beneficência, alude que não são obras somente de caridade, mas de "justiça social", ao mesmo tempo trazendo essa nova expressão e a diferenciando da própria caridade. Podemos citar mais dois textos anteriores à Quadragésimo Anno que utilizam a referida expressão, uma carta de 20.07.1929, enviada pelo Cardeal Gasparri, na qual ele se refere à justiça social, dizendo que "é louvável seu empreendimento de lembrar e explicitar as exigências da moralidade pessoal, da justiça social e da caridade", e, por fim, em documento de 1923 escrito por Pio XI, onde discorre sobre São Tomás (CALVEZ, PERRIN, 1960, p. 231).

Pio XI introduz o conceito de justiça social na Encíclica Quadragesimo Anno:

É próprio da justiça social exigir dos particulares tudo o que é necessário para o bem comum. Mas, assim como aquilo que se refere ao conjunto de qualquer corpo vivo se não alcança plenamente, se a cada membro

\footnotetext{
${ }^{69}$ Caridade paliativa é o termo que se dá àquela caridade que, ainda que atingindo seu objetivo, não combate à causa, e é geralmente aplicada em momentos críticos.
} 
particular não é fornecido tudo aquilo que ele precisa para poder exercer as suas funções, assim também, no atinente à organização e equilíbrio da comunidade, não é possível chegar ao bem de toda a sociedade, se a cada um de seus membros particulares - os homens, com sua dignidade de pessoas (g.n.) - não é fornecido o necessário para exercer a função social que lhe incumbe (CALVEZ, PERRIN, 1960, p. 238).

Neste mesmo documento, o Papa também trata da questão do salário-mínimo, indicando um dos parâmetros para seu estabelecimento, pois afirma que o salário deve garantir a sustentação da família. Continua Pio XI a indagar que, se o empregador não suporta esse ônus, a justiça social exige que se proceda às mudanças necessárias para o empregador assegurar esse salário suficiente ao empregado. Isso não significa igualdade de resultados.

A insatisfação com o Estado que permite a concentração de bens na mão de poucos, e assiste impassível o aumento da pobreza dos trabalhadores, sujeitos cada vez mais às doenças e às péssimas condições no trabalho, faz que com que estes se mobilizem para a alteração desta triste situação, e, com isso, se mobilizem a, unidos, conclamarem melhor situação. Surge assim o movimento sindical, que, mesmo sendo inicialmente combatido como crime, gerando grandes injustiças, foi, sem dúvida, um dos elementos precursores do Estado de Bem-Estar Social. É o que afirma José Correia Villela (2006):

Com os movimentos do operariado, iniciados no século XIX, os direitos sociais foram surgindo paulatinamente e, mais tarde, influenciaram o constitucionalismo social do século XX, a começar pela Constituição Mexicana, de 1917, e pela Constituição de Weimar, de 1919.

A partir dessas conquistas alcançadas por meio de luta e sangue, os direitos sociais, em especial os direitos trabalhistas, passaram a ser positivados, inaugurando o movimento conhecido como Constitucionalismo Social, com a Constituição Mexicana de 1917 e a Constituição de Weimar, de 1919, pioneiras na inserção de rol de direitos dos trabalhadores em sede constitucional.

Destaque para a Constituição Mexicana de 1917, arrojada e inovadora ao inserir em seu corpo direitos trabalhistas, a um nível de sofisticação impressionante. Talvez sua maior contribuição foi a de alçar à categoria de Direitos Fundamentais os Direitos Trabalhistas, 
ou seja, caracterizar o trabalho como direito fundamental que eleva, promove e exalta a dignidade do homem.

A seguir, serão transcritos e comentados alguns dos principais aspectos tratados na Constituição Mexicana, eleita pelo significado que atribuiu ao Direito do Trabalho, expondo, dessa maneira, a verve protetiva de que se imbuiu aquele documento.

Note-se que o art. 123 refere-se ao trabalho como direito de toda pessoa, que deverá ser criado e organizado conforme a lei, além de estender a limitação de jornada de 8 horas diárias e outros direitos ao trabalhadores, jornaleiros, empregados, domésticos, ou seja, para qualquer pessoa que exerça trabalho, sendo ele emprego ou não:

\begin{abstract}
ARTICULO 123 - Toda persona tiene derecho al trabajo digno y socialmente útil; al efecto, se promoverán la creación de empleos y la organización social para el trabajo, conforme a la ley. El Congreso de la Unión, sin contravenir a las bases siguientes, deberá expedir leyes sobre el trabajo, las cuales regirán:

A. Entre los obreros, jornaleros, empleados, domésticos, artesanos, y de una manera general, todo contrato de trabajo:
\end{abstract}

Note-se ainda que o art. 123 traz um rol sofisticadíssimo de direitos trabalhistas, mormente ao se constatar que esta é a primeira Constituição que trata do direito dos trabalhadores, ou seja, logo na primeira experiência já traz esse refinamento quanto ao nível de proteção atribuído:

I. La duración de la jornada máxima será de ocho horas;

II. La jornada máxima de trabajo nocturno será de siete horas. Quedan prohibidas: las labores insalubres o peligrosas, el trabajo nocturno industrial y todo otro trabajo después de las diez de la noche, de los menores de dieciseis años;

IV. Por cada seis días de trabajo deberá disfrutar el operario de un día de descanso, cuando menos;

$\mathrm{O}$ artigo referido continua progredindo, ao eleger, entre outros direitos, numa surpreendente moldura de novidade, a proteção do menor e da mulher, que, notoriamente, foram duas categorias humanas extremamente exploradas e vilipendiadas no decorrer da história do Direito do Trabalho:

III. Queda prohibida la utilización del trabajo de los menores de catorce años. Los mayores de esta edad y menores de dieciseis, tendrán como jornada máxima la de seis horas; 
V. Las mujeres durante el embarazo no realizarán trabajos que exijan un esfuerzo considerable y signifiquen un peligro para su salud en relación con la gestación; gozarán forzosamente de un descanso de seis semanas anteriores a la fecha fijada aproximadamente para el parto y seis semanas posteriores al mismo, debiendo percibir su salario íntegro y conservar su empleo y los derechos que hubieren adquirido por la relación de trabajo. En el período de lactancia, tendrán dos descansos extraordinarios por día, de media hora cada uno, para alimentar a sus hijos.

Outro ponto trazido pela Constituição Mexicana foi a proteção ao salário mínimo, indispensável na proteção social do trabalhador, tendo em vista seu objetivo de garantir a manutenção de sua vida e de sua família:

VI. Los salarios mínimos que deberán disfrutar los trabajadores serán generales o profesionales. Los primeros regirán en las áreas geográficas que se determinen; los segundos se aplicarán en ramas determinadas de la actividad económica o en profesiones, oficios o trabajos especiales.

Los salarios mínimos deberán se suficientes para satisfacer las necesidades normales de un jefe de familia, en el orden material, social y cultural, y para proveer a la educación obligatoria de los hijos. Los salarios mínimos profesionales se fijarán considerando, además, las condiciones de las distintas actividades económicas.

Los salarios mínimos se fijarán por una comisión nacional integrada por representantes de los trabajadores, de los patrones y del gobierno, la que podrá auxiliarse de las comisiones especiales de carácter consultivo que considere indispensables para el mejor desempeño de sus funciones;

VII. Para trabajo igual debe corresponder salario igual, sin tener en cuenta sexo ni nacionalidad.

Nesse contexto de constitucionalização de Direitos Sociais, importa a análise da Constituição Brasileira de 1988, também conhecida como Constituição Cidadã, que, dentre todas as Constituições Brasileiras, seguramente é a que mais se envolveu e projetou a política humanista, elevando os Direitos Sociais a nível constitucional, e impulsionando a efetivação desses direitos como instrumentos de alcance da dignidade humana. $\mathrm{O}$ artigo $7^{\circ}$ da $\mathrm{CF} / 88$ traz extenso rol de direitos trabalhistas, que, como a Constituição Mexicana de 1917, promovem o bem estar social do trabalhador, indicando limites quanto à dispensa imotivada $^{70}$, limitação a jornada de trabalho, garantia de férias, $13^{\circ}$ salário, irredutibilidade salarial, etc.

\footnotetext{
${ }^{70}$ Ainda que a lei complementar que deverá regulamentar essa questão, mesmo após 22 anos da promulgação da $\mathrm{CF} / 88$, ainda não tenha surgido...
} 
A importância do Constitucionalismo Social se dá na medida em que a inicial busca do Bem-Estar Social cede cada vez mais espaço para a flexibilização de Direitos que já são exercidos no seu patamar mínimo, ou seja, a proteção constitucional toma contornos de suma importância no atual estágio de desregulamentação dos Direitos Sociais, dificultando a alteração ou a supressão legislativa desses direitos.

A proteção social do trabalhador, conforme demonstra a evolução do Estado Liberal para o Estado do Bem-Estar Social, pode ser definida como a intervenção estatal nas relações de trabalho, reconhecendo as condições materiais em que se desenvolvem os contratos de trabalho, e, consequentemente, a hipossuficiência do trabalhador, necessitando, assim, criar acesso com igualdade ao trabalho e as condições de trabalho adequadas.

Quer parecer que a OIT sugere a mesma idéia no que respeita à proteção social, como se depreende da exposição de seu então Diretor Geral Juan Somavia (1999), por ocasião de seu Memorial oferecido na $87^{\mathrm{a}}$ Conferência Internacional:

Protección contra la vulnerabilidad y los sucesos imprevistos. Porque desea que las condiciones de trabajo sean humanas, la OIT tiene que interesarse por la vulnerabilidad y los imprevistos que retiran a la gente del trabajo, independientemente de que se deban al desempleo, a la pérdida de los medios de subsistencia, a la enfermedad o a la vejez ${ }^{71}$.

\subsubsection{Fortalecimento do tripartismo e do diálogo social}

A OIT oferece como quarto e último objetivo a ser alcançado para a promoção do trabalho decente o fortalecimento do tripartismo e do diálogo social.

Tripartismo é a oportunidade de, conjuntamente, governo, trabalhadores e empregadores se manifestarem a respeito de assuntos do mundo do trabalho que afeta a todos. É o que relata a OIT (2007), quando afirma que:

\footnotetext{
${ }^{71}$ Proteção contra vulnerabilidade e acontecimentos inesperados. Porque deseja que as condições de trabalho sejam humanas, a OIT deve se preocupar com a vulnerabilidade e contingências que retiram as pessoas do trabalho, independentemente se eles são devidos ao desemprego, a perda dos meios de subsistência, a doença ou a velhice.
} 
O tripartismo se apóia na relação especial dos constituintes da OIT, na qual os trabalhadores, empregadores e governos contribuem para melhorar os padrões das relações no local de trabalho e a proteção dos direitos dos trabalhadores no mundo.

A OIT, no mesmo estudo que traz o conceito de tripartismo acima aludido, também demonstra o que crê ser a finalidade deste fenômeno, indicando como ele auxilia o avanço social e econômico ao afirmar que ele promove o crescimento econômico contínuo e o desenvolvimento social.

A OIT (2010a) oferece um conceito de diálogo social, que, pode-se perceber, não se confunde com o tripartismo, antes indica que este fenômeno é uma das possibilidades, dentre várias, de diálogo social:

La definición de diálogo social con que trabaja la OIT incluye dentro del mismo todo tipo de negociación, consulta o simple intercambio de informaciones entre representantes de gobiernos, empleadores y trabajadores sobre cuestiones de interés común relacionadas con la política económica y social. Puede cobrar la forma de un proceso tripartito donde el gobierno es parte oficial en dicho diálogo o consistir en relaciones de carácter bipartito entre trabajadores y empleadores, o bien, entre organizaciones de trabajadores y de empleadores, con o sin intervención indirecta del gobierno. La concertación puede ser oficiosa u oficial, siendo con frecuencia una combinación de ambos tipos. Puede tener lugar en los planos nacional, regional o de la empresa. También puede ser interprofesional, intersectorial o una combinación de tales formas ${ }^{72}$.

Diálogo social, conforme o conceito daquela Entidade, é um termo de significado bastante alargado, como também aduz FEMENÍA et al. (2007):

\footnotetext{
${ }^{72}$ A definição de diálogo social com que trabalha a OIT inclui dentro do mesmo todo, os tipos de negociação, consulta ou, simplesmente, intercâmbio de informações entre representantes de governos, empregadores e trabalhadores sobre questões de interesse comum relativas à política econômica e social. Pode tomar a forma de um processo tripartite, onde o governo é parte oficial no aludido diálogo ou consistir em relações de caráter bipartite entre trabalhadores e empregadores, ou entre as organizações dos trabalhadores e empregadores, com ou sem intervenção indireta do governo. O pacto pode ser informal ou institucionalizado, e muitas vezes uma combinação de ambos. Pode ter lugar a nível nacional, regional ou corporativo. Ele pode ser interprofissional, intersetorial ou uma combinação dessas formas.
} 
No hay um consenso general sobre la definición de diálogo social, existiendo uma gran variedad de términos utilizados. La OIT tiene uma definición amplia, que refleja uma extensa variedad de procesos y prácticas que se encuentran em los distintos países. Ségun esa definición, el diálogo social comprende todo tipo de negociaciones y consultas o, simplemente, el mero intercambio de información entre los representantes de los gobiernos, de los empleadores y de los trabajadores, sobre cuestiones de interes común relativas a las políticas econômicas y sociales $^{73}$.

No mesmo documento em que a OIT oferece seu conceito de diálogo social, explicita ainda qual é o principal objetivo a ser atingido por ele, além de fazer notar que este instituto é representativo dentro de um sistema democrático:

El principal objetivo del diálogo social propiamente dicho es el de promover el logro de un consenso y la participación democrática de los principales interlocutores presentes en el mundo del trabajo. Las estructuras del diálogo social así como los procesos que se han desarrollado con éxito han sido capaces de resolver importantes cuestiones de índole económica y social, han alentado el buen gobierno, el progreso y la paz sociales, la estabilidad e impulsado el desarrollo económico ${ }^{74}$.

Observando o significado de tripartismo e de diálogo social, pode-se deduzir que os dois elementos são próximos, haja vista que o tripartismo é fundamento do diálogo social especialmente no que ser refere ao mundo do trabalho.

Quer parecer ser muito desejável que decisões que impactam no cotidiano desses três atores sociais de maneira tão contundente sejam por eles debatidas, para que possam gerar, no diálogo social, oportunidades de manifestarem uns aos suas opiniões, de enfrentarem pontos de divergência para, juntos, procurarem possíveis soluções para as dificuldades que enfrentam, estabelecer as melhores vias para esse debate, etc.

\footnotetext{
${ }^{73}$ Não há consenso geral sobre a definição do diálogo social, existindo uma grande variedade de termos utilizados. A OIT tem uma definição mais ampla, refletindo uma vasta gama de processos e práticas que se encontram em diversos países. Segundo esta definição, o diálogo social inclui todos os tipos de negociações e consultas ou, simplesmente, a mera troca de informações entre representantes de governos, empregadores e trabalhadores sobre questões de interesse comum no domínio das políticas económicas e sociais.

${ }^{74}$ O objetivo principal do diálogo social em si é promover a construção de um consenso e a participação democrática dos principais interlocutores no mundo do trabalho. As estruturas de diálogo social, assim como os processos que se desenvolveram com êxito têm sido capazes de resolver importantes questões de índole econômica e social, promover a boa governança, o progresso e a paz social, a estabilidade e impulsionado o desenvolvimento econômico.
} 
Isso porque os mais diversos interesses podem e devem encontrar pontos de convergência que eliminem ou diminuam conflitos que possam surgir da relação entre governo, empregador e trabalhador, buscando, assim, atingir um consenso social que, ainda que não seja absoluto, certamente se mostra muito adequado para obter o maior equilíbrio social possível, pois, afinal, melhorar as condições de vida e de convivência é certamente desejo de todos e um objetivo a ser perseguido.

A Organização Internacional do Trabalho reconhece claramente a importância dessa oportunidade de diálogo, como se pode ver do trecho abaixo transcrito, pertencente a um texto do Projeto Diálogo Social, abraçado pela entidade:

Os empregadores e os trabalhadores são o motor do processo produtivo, e
são aqueles que conhecem melhor do que ninguém o impacto das
decisões políticas na empresa e no local de trabalho. As melhores
medidas em política econômica e social não são necessariamente as
melhores do ponto de vista técnico, mas aquelas que sendo sólidas
tecnicamente tenham também a aceitação do conjunto da sociedade. O
desenvolvimento de um diálogo social eficaz passa pelo fortalecimento
dos seus atores. O exercício por parte das organizações sindicais de uma
ação sindical sólida, assim como a potencializaçãa da negociação coletiva
em diversos níveis, são elementos que redundam em um diálogo social
que beneficie ao conjunto dos trabalhadores e trabalhadoras. E vice-versa,
a existência dos mecanismos do diálogo social podem orientar a ação
sindical e ajudar a promoção da negociação coletiva (OIT, 2005).

A OIT demonstra ter grandes expectativas em torno do tripartismo e do diálogo social como instrumento de promoção e manutenção do trabalho decente. Promove muitos esforços nesta direção, a começar pelo Projeto Diálogo Social, que é uma das diretrizes estratégicas pensadas pelo órgão como forma de inclusive promover a integração regional, importante para o fortalecimento e desenvolvimento da América Latina.

O referido projeto visa contribuir para uma melhor estruturação democrática, permitindo assim que uma grande variedade de assuntos relacionados à economia e ao trabalho, de interesse comum às partes, sejam reconhecidos e debatidos, e, por consequência, há o fortalecimento desses atores sociais. São seis os países latinoamericanos partícipes, a saber: Argentina, Brasil, Chile, Equador, México e Peru.

Outro elemento privilegiado pela Entidade no desenvolvimento desses esforços de diálogo é a negociação coletiva, que, claro, exige que os entes sindicais sejam fortes e mantenham uma ação incisiva nesse contexto. 


\subsection{O trabalho decente na doutrina nacional e internacional}

Primeiramente, importa salientar que este tema é muito mencionado, mas bem pouco debatido na doutrina nacional ou mesmo na internacional. Muitos clamam pela sua necessidade, pela sua efetivação, mas poucos foram, de acordo com os levantamentos realizados, os doutrinadores que se debruçaram sobre o conceito de trabalho decente, daí a dificuldade desta missão, de inserir na vertente tese o que reflete a doutrina nacional e internacional a respeito do assunto, missão esta da qual se espera desonerar com êxito.

Para esta tarefa, serão selecionadas não apenas doutrinas que tratem do conceito de trabalho decente, mas também dos elementos que o concretizam ou o dilapidam, para contribuir no melhor esclarecimento da questão.

Cristian Ramos, em estudo promovido pela OIT, traz um conceito de trabalho decente um pouco diferente daquele apresentado por Somavia por ocasião da $87^{\mathrm{a}}$ Conferência, como se pode denotar da transcrição abaixo:

O trabalho que é capaz de superar a pobreza, reduzir as desigualdades sociais e contribuir para a ampliação da cidadania e a garantia da governabilidade democrática é o que a OIT convencionou chamar de Trabalho Decente.

Assim, o conceito de RAMOS amplia um pouco a perspectiva da OIT, na medida em que atribui ao trabalho decente o objetivo de contribuir para a ampliação da cidadania e para a garantia da governabilidade democrática.

No que respeita à ampliação da cidadania, pode-se imaginar que o trabalho decente de fato aumenta a participação do trabalhador na vida cívica, porque um dos efeitos do trabalho exercido com dignidade é a inclusão social deste indivíduo. Paulo Cruz deduz a cidadania como a

Participação política, e, por isto, deve-se considerar a Cidadania como dimensão pública da participação do homem na vida social e política do Estado. Apesar disto, não se pode negligenciar os aspectos que digam respeito a elementos culturais, sócio-políticos, históricos e, 
principalmente éticos, que se apresentam com esta condição do ser social. (2000)

A participação política do trabalhador-cidadão pode dar-se de diversas formas, mas sem dúvida, nesta constituição fática das relações de trabalho, é a partir da perspectiva de atividade sindical que o obreiro se coloca na vida cívica de modo mais contundente.

RAMOS ainda atribui ao trabalho decente a contribuição para a garantia da governabilidade democrática. Necessária alguma digressão sobre governabilidade, para que se entenda o contexto onde o Autor insere o conceito de trabalho decente.

José Luís Fiori (1995) resume as variações das teorias econômicas acerca da governabilidade. $\mathrm{Na}$ década de 50 , as teorias econômicas se voltavam para a idéia de desenvolvimento econômico com "a conjugação democrática da periferia capitalista". Já na década de 60, o desenvolvimentismo começa a ceder espaço para a governabilidade. Em 1965, diagnosticada "profunda crise dos países industrializados e a natureza instável e reversível dos desenvolvimentos democráticos nas periferias capitalistas", o foco das discussões se concentram na "estabilidade política ou, mais precisamente, da preservação da ordem ou da governabilidade".

A partir dessa visão, governabilidade pode ser entendida como a capacidade do governo de "atender certas demandas, ou então de suprimi-las de vez". No decorrer dos anos, esta definição foi sendo revista e modificada, passando do "neoliberalismo econômico de Hayek e seus seguidores e a corrente de pensamento político que estréia com a teoria dos jogos", para a "teoria da ação racional”, chegando ao ápice com a "escola da escolha pública".

Essa nova economia política foi a responsável pela fundamentação teórica da "revolução liberal" do final do século XX. Das idéias de "virtude e de interesse público", passou-se à economic approach to politics. Explica o Autor que:

Ao aprofundar e sistematizar a metáfora de Schumpeter sobre a política enquanto mercado e o cálculo do interesse individual como fundamento último do comportamento dos eleitores, das burocracias e da classe política, acaba por reduzir o Estado, os governos e os sistemas políticos a uma soma de indivíduos que, basicamente, se orientam pela busca de vantagens individuais através do acesso seletivo e do manejo arbitrário dos recursos e das 
políticas públicas. Com a grande diferença de que, ao contrário dos mercados econômicos, nesses mercados políticos a mão invisível atuaria de forma inversa ou perversa, permitindo que seus produtos (as decisões e políticas públicas) fossem invariavelmente irracionais do ponto de vista econômico. (1995, p. 2)

Com o final da segunda guerra mundial, essa teoria, de forma implícita, demonstra que $\mathrm{o}$ funcionamento das democracias de massa $^{75}$ eram responsabilizadas pela ingovernabilidade, que culminou na crise econômica e na instabilidade política dos anos $70^{76}$. Em meados de 80, o enxugamento da intervenção estatal chega a seu ápice com a teoria do Estado mínimo, ou seja, a limitação maior das atividades reguladoras do Estado. Ainda nesta década, como aponta FIORI, essa teoria foi suavizada por Anthony Downs:

(...) que havia inaugurado em 1957 a nova escola, com sua Economic Theory of Democracy propôs uma autocrítica corretiva de sua visão inicial sobre a racionalidade da ação política, sintetizando as bases do que alguns chamam de neoinstitucionalismo: "na realidade, os valores sociais classificados pelos economistas como preferenciais ou gostos dados são extremamente importantes em cada sociedade. Sua natureza e transformações afetam significativamente os comportamentos e instituições políticas e econômicas" (1991). Do ponto de vista normativo, contudo, o neo-institucionalismo apenas enriqueceu o que seria a estratégia neoliberal de Buchanan, acrescentando-lhe a seguinte idéia-síntese, aliás, do próprio Downs, a saber, que "o bem-estar da sociedade e dos indivíduos envolvidos poderia ser enormemente melhorado se eles pudessem ser induzidos a comportar-se de acordo com valores pessoais e sociais diferentes dos que possuem atualmente". (1995, p. 3)

\footnotetext{
${ }^{75}$ Democracia de massa representa a inserção no jogo político de todas as camadas da população, burguesia, classe média, pobres, urbanos, rurais.

${ }^{76}$ No Brasil, há uma tendência entre alguns economistas, como Gustavo Franco, de creditar à chamada democracia de massa o processo sofrido no país de hiperinflação ocorrido nos primeiros anos de abertura democrática pós 1985 .
} 
Nos anos 90, uma versão do que se apresentou na década anterior é apresentada, aparecendo inclusive na "agenda do Banco Mundial e de outras instituições multilaterais", chamada de governance ou good governance, conforme desenvolvido no trabalho Governance and Development. Governança ou boa governança foram termos cunhados pelo Banco Mundial para designar a maneira pela qual o poder é exercido na administração dos recursos sociais e econômicos de um país visando o desenvolvimento com equidade e sustentabilidade, através da capacidade dos governos de planejar, formular e implementar políticas e cumprir funções ${ }^{77}$. A partir do Consenso de Washington o conceito de boa governança passa a tomar contornos mais claros, porque lá essa idéia passa a ser mais evidente:

Governabilidade ou good governance, neste caso, passou a ser sinônimo ou resultado da capacidade dos reformistas de acumularem inicialmente "an unusual concentration of power" (Nelson, 1989, p. 16) mediante a formação de uma coalizão ampla, sólida e permanente de poder que obtivesse a "allegiance of the bourgeoisie" (Whithead, 1989, p. 80) uma vez que "in practice it may take very little in material rewards to purchase the allegiance of the lower class" (idem, p. 81). Para isto os autores sugerem igualmente a insularização burocrática de um núcleo de technopols (Williamson, 1992) que possa comandar a economia distante das pressões corporativas. (Fiori, 1995, p. 4)

Boa governança, assim, acaba contextualizada na agenda neoliberal, que, sabidamente, trouxe grandes perdas aos Direitos Sociais. Wilson Amorim esclarece como no passado recente brasileiro se deu o movimento de flexibilização:

Nos últimos quinze anos a economia brasileira experimentou mudanças estruturais importantes. Nesse período, verificou-se um conjunto de condicionantes estruturais inéditas como a queda da inflação, a abertura econômica, o regime de câmbio flexível e a diminuição da intervenção do Estado, notadamente no âmbito da produção. No campo das relações de trabalho, as negociações coletivas - fortemente condicionadas por este novo ambiente econômico - ocorreram segundo novas condições. Entre elas, o fim das políticas salariais - que desde os governos militares guiaram as negociações entre patrões e empregados -, a regulamentação em lei da participação nos lucros e resultados e um conjunto de novas

\footnotetext{
${ }^{77} \mathrm{O}$ presidente do Banco Mundial à época aduz que "Good governance is an essential complement to sound economic policies. Efficient and accountable management by the public sector and a predictable and transparent policy framework are critical to the efficiency of markets and governments, and hence to economic development. The World Bank's increasing attention to issues of governance is an important part of our efforts to promote equitable and sustainable development”. (World Bank, 1992, p. v)
} 
orientações legais de natureza flexibilizadora quanto à contratação do trabalho em sua duração e jornada e mesmo a contratação por tempo determinado e o trabalho em regime de tempo parcial. No âmbito da Justiça do Trabalho, o Tribunal Superior do Trabalho cancelou vários precedentes normativos favoráveis aos trabalhadores na segunda metade da década de 90. (2009, p. 4-5)

A própria $\mathrm{CF} / 88$ em seu texto original, ainda que de fato tenha vocação humanista e de cunho social, traz em seu bojo normas ao mesmo tempo flexibilizadoras desses mesmos direitos sociais que defende. A exemplo, o artigo $7^{\circ}$, inciso XIII, que estabelece limites à jornada de trabalho, com "duração do trabalho normal não superior a oito horas diárias e quarenta e quatro semanais", reconhecendo os limites humanos ao trabalho, mas, ao mesmo tempo, permitindo, com a intervenção do sindicato, a compensação de horários e a redução da jornada, mediante acordo ou convenção coletiva de trabalho, bem como, no inciso XIV, umas das jornadas mais prejudiciais ao ser humano, a do turno ininterrupto de revezamento, de seis horas.

No primeiro mandato de Fernando Henrique Cardoso como presidente da república, que aderiu às idéias propagadas pelo Consenso de Washington e implantou de forma robusta essas políticas, encontra-se outra ilustração da flexibilização sofrida no Brasil, qual seja, a reforma na seguridade social ocorrida a partir de 1998, com a Emenda Constitucional (EC) n. 20.

Notadamente, a idéia de governabilidade está ligada à aplicação da racionalidade administrativa ao governo, ou seja, é o "movimento inverso" da representação. Representação pressupõe a "capacidade dos governados de controlar a ação dos governantes e deste modo participar do governo", como estabelece Marco Aurélio Nogueira, enquanto a governabilidade pressupõe a "capacidade que os governantes têm de tomarem decisões que atendam demandas efetivas dos governados $e$ de viabilizarem a reprodução das condições de preservação do poder (g.n.)" e, por isso, "colide frontalmente com a idéia de participação", porque se transforma em aplicação do tecnicismo, "como uma operação fechada, passível de ser pensada e resolvida sem maiores referências ao ambiente societal, aos movimentos da política e da economia", que tem como valor máximo a eficiência e a eficácia.

Assim, aquela idéia inicial de governabilidade conjugando desenvolvimento econômico com democracia se torna incongruente quando se descortina o que efetivamente prevaleceu em termos de governabilidade, ou seja, de manutenção do poder no governo 
para a implantação eficaz das políticas neoliberais - flexibilizadoras dos Direitos Sociais contornadas mais atualmente pelo Consenso de Washington.

Governabilidade democrática, neste contexto, não pode coexistir com a noção de trabalho decente, haja vista que se teoricamente une idéias como desenvolvimento econômico e bem-estar social - medindo a capacidade que as Democracias têm na reprodução do capitalismo no Estado de bem-estar social - não se pode ignorar que os efeitos concretos dessa política não demonstram esse resultado, ao contrário, o que se vê é a promoção de políticas econômicas que favorecem apenas determinados segmentos sociais em detrimento das políticas sociais mais abrangentes e vitais.

Outro conceito de trabalho decente que se vislumbra é o trazido pelo Ministério do Trabalho e Emprego do Brasil, que o define como "trabalho adequadamente remunerado, exercido em condições de liberdade, eqüidade e segurança, capaz de garantir uma vida digna" (2006). Não traz nenhuma inovação quanto ao conceito da OIT, ao contrário, baseia-se nitidamente nele.

A idéia de trabalho decente é materializada por meio de diversos elementos, dentre os quais a remuneração que, como aduz Dharam Ghai (2006, p.4), é um dos seus pilares, juntamente com a liberdade de associação, a proteção contra a discriminação, o combate ao trabalho forçado e ao trabalho infantil. Todos esses paradigmas podem se enquadrar, na definição da OIT, na promoção dos direitos fundamentais do trabalho e na proteção social.

No entanto, Ghai alerta que essa concepção de trabalho decente é o desejo de todos, mas que a implementação depende de cada país, por conta da diversidade cultural, social, econômica:

\begin{abstract}
"Thus the objectives of decent work are of universal aspiration. But the institutional and policy framework for achieving these objectives must necessarily depend in each country and region on its history and traditions, the level and distribution of resources, the economic and social structure, the stage of development and a host of other specific circumstances. While each country needs to formulate its own decent work policies in the light of these specificities, it may be useful for purposes of discussion to group countries into a few categories whose members share some distinctive socio-economic characteristics" $"$.
\end{abstract}

\footnotetext{
78 Assim que os objetivos do trabalho decente são de aspiração universal. Mas o quadro institucional e de política para alcançar esses objetivos deve necessariamente depender, em cada região e país, de sua história e tradições, o nível de distribuição de recursos, a estrutura econômica e social, o estágio de desenvolvimento e
} 
O referido Autor afirma ainda que emprego é fundamental para o trabalho decente, mas atribui ao termo não apenas o significado de trabalho assalariado, mas qualquer tipo de trabalho que satisfaça determinadas condições que levam o trabalhador à dignidade:

Employment is a vital component of decent work. Employment in the decent work paradigm refers not just to wage jobs but to work of all kinds - self-employment, wage employment and work from home. It refers to full-time, part-time and casual work and to work done by women, men and children. For decent work to obtain, certain conditions must be satisfied. There should be adequate employment opportunities for all those who seek work. (GHAI, 2006, p. 10) ${ }^{79}$

O doutrinador então indica quais são as principais condições que, em sua visão, estabelecem a decência em um trabalho:

Work should yield a remuneration (in cash or kind) that meets the essential needs of the worker and the family members. Work should be freely chosen and there should be no discrimination against any category of workers, such as women, migrants or minorities. Workers should be protected against accidents, unhealthy and dangerous working conditions, and excessively long hours of work. They should have the right to form and join representative and independent associations to represent their interests and engage in collective bargaining and in discussions with employers and government authorities on work-related issues. An essential minimum of social security also forms part of decent work. Some of these attributes of employment are discussed further under rights

uma série de outras circunstâncias particulares. Enquanto cada país precisa formular suas próprias políticas de trabalho decente à luz destas especificidades, pode ser útil, para propósitos de discussão, agrupar países em algumas categorias cujos membros dividem assim certas características socioeconômicas (tradução nossa).

79 Emprego é um componente vital do trabalho decente. Emprego, no paradigma do trabalho decente, se refere não apenas ao trabalho assalariado mas trabalhos de todos os tipos - autônomos, trabalho assalariado, trabalho em casa. Se refere a empregos casuais, de meio-período e integral, e trabalho feito por mulheres, homens e crianças. Para se obter trabalho decente, certas condições precisam ser satisfeitas. Deve haver oportunidades adequadas de emprego a todos os que buscam trabalho (tradução nossa). 
at work, social security and social dialogue. Work that meets the above conditions is a source of dignity, satisfaction and fulfilment to workers. It motivates them to give their best efforts and furnishes a sense of participation in matters affecting their livelihood. It provides a propitious foundation for skills enhancement, technological progress and economic growth. It also contributes to harmonious working relations, political stability and the strengthening of democracy. (GHAI, 2006, p. 10-11) $)^{80}$

O que se pode perceber das condições indicadas pelo Autor para caracterizar trabalho decente (proteção contra acidentes, doenças, más condições de trabalho, jornada excessiva) é que, no Brasil, se equiparam à proteção que existe em relação a uma especialidade de trabalho, que é o emprego.

Em assim sendo, parece certo que a forma de labor que mais representa o ideal do trabalho decente é o emprego, já que é a única espécie que conta com efetiva rede legal de proteção contra a precarização do trabalho, com exceção dos avulsos, que aos empregados são equiparados pela $\mathrm{CF} / 88$.

Gosdal não apresenta em sua obra exatamente um conceito de trabalho decente, mas oferece uma visão acerca do tema, que em muitos pontos coaduna com o conceito trazido pela Organização Internacional do Trabalho:

O trabalho decente está voltado à promoção do progresso social, à redução da pobreza e a um desenvolvimento eqüitativo e integrador, em face da crescente situação de interdependência dos diferentes países na atualidade. Não se coaduna com todas as reformas trabalhistas que vêm sendo propostas por segmentos empresariais, voltadas à total

\footnotetext{
${ }^{80}$ Trabalho deve perceber remuneração (em moeda corrente ou em espécie), e uma que vá de encontro às necessidades essenciais do trabalhador e dos membros de sua família. O trabalho deve ser escolhido livremente e não deve haver discriminação contra qualquer categoria de trabalhadores, como mulheres, imigrantes ou minorias. Trabalhadores devem ser protegidos contra acidentes, condições de trabalho perigosas e insalubres, e jornadas excessivamente longas de trabalho. Eles devem ter o direito de formar e se filiar a associações representativas independentes para representar seus interesses e se engajar em barganha coletiva e em discussões com empregadores e autoridades governamentais em assuntos relativos a seu trabalho. Um mínimo essencial de seguridade social faz parte do trabalho decente. Alguns desses atributos são posteriormente discutidos como direito no trabalho, seguridade social e diálogo social. O trabalho que vai de encontro às condições acima é uma fonte de dignidade, satisfação e preenchimento para os trabalhadores. Os motiva a dar seus melhores esforços e dá um senso de participação em matérias que afetam seu sustento. Provê uma fundamentação propícia para o aperfeiçoamento de competências, progresso tecnológico e crescimento econômico. Também contribui para relações trabalhistas harmoniosas, estabilidade política e fortalecimento da democracia. (Tradução nossa).
} 
flexibilização de direitos. Não é compatível com a violação dos direitos fundamentais reconhecidos pelo ordenamento jurídico, como por exemplo, com a prática de revistas íntimas nos empregados, que violam seu direito à intimidade e privacidade; com a exploração do trabalho forçado, ou análogo à condição de escravo, que a realidade tem evidenciado ser ainda comum na atualidade; com a exploração do trabalho infantil, não apenas nas atividades de exploração sexual, mas também no trabalho familiar, com diversas formas de discriminação no emprego, especialmente de gênero e raça. (2007, p. 130)

O trabalho decente só surge conceituado a partir da iniciativa da OIT, o que já determina a importância desta ação. Aliás, maciçamente, pode-se perceber pesquisando o tema que, a parte mais significativa dos estudos sobre trabalho decente de modo geral não apenas seu conceito - se deu a partir de estudos promovidos pela OIT.

Descortina-se, a partir desta vertente pesquisa, que a OIT teve um papel de destaque, iniciando as propostas de desenvolvimento do trabalho decente, sendo pioneira ao conceituar o termo, propondo estudos e viabilizando políticas universais e regionais para sua implementação.

O que se nota é a escassez de doutrinas, tanto nacionais quanto internacionais sobre trabalho decente que não partam da OIT, e, mesmo quando o estudo é promovido a partir de outra fonte, que não daquela instituição internacional, ainda assim, quando seus autores apresentam o conceito de trabalho decente, o fazem baseado na definição da OIT, daí a similitude entre os conceitos aqui fornecidos. 


\section{A RECONSTRUÇÃO DO CONCEITO DE TRABALHO DECENTE E SUA EFICÁCIA}

\subsection{Análise crítica do trabalho decente da OIT}

No próximo tópico, a pesquisa prossegue tecendo e justificando as críticas plausíveis ao conceito de trabalho decente difundido pela OIT, mostrando como um conceito que traduza os ideais principiológicos do Direito do Trabalho podem concretizar sua eficácia. Ressalte-se, no entanto, a importância daquele Organismo Internacional na medida em que é uma dos poucas instituições que se debruçam sobre tão árduo tema, e a pretensa contribuição deste vertente trabalho é auxiliar na tarefa de estabelecer um conceito que, ainda que abrangente, possa trazer mais eficácia à sua aplicação.

Imaginar que o conceito de trabalho decente pode ser absolutamente específico, ou mesmo ter sua generalidade sensivelmente tangida, é exigência que não se pode dar cabo, tendo em vista que o termo abarca tantos e tão diversos elementos. Ademais, um dos objetivos de que o conceito seja mais refinado (o que não significa absolutamente especificado) é atribuir-lhe maior efetividade, para que possa ter mais aplicabilidade, e servir de paradigma na criação de normas, na interpretação do direito e na criação de políticas públicas voltadas ao trabalhador.

Assim, as críticas que serão suscitadas devem ser lidas na medida em que possam contribuir com o refinamento do conceito de trabalho decente, que surge estabelecido pela OIT, mas que certamente, pela relevância que assume na defesa e na resistência dos trabalhadores ante aos projetos de desregulamentação das normas protetivas trabalhistas, pode materializar melhorias nas suas condições de labor.

\subsubsection{Igualdade das partes no contrato de trabalho}

O conceito de trabalho decente criado e promovido pela OIT merece crítica na medida em que não aponta um problema basilar enfrentado pelo trabalhador na realização do contrato de emprego, qual seja, que é reconhecido formalmente como parte de um 
contrato (de emprego), mas que concretamente não detém nenhum poder de manifestação de vontade dentro do referido instrumento. Ou seja, na prática, assim um contrato, com regras que vigerão sua vida produtiva sem que tenha real oportunidade de debater e escolher essas regras. Quando muito, apenas anui àquelas cláusulas.

O direito do trabalho tem, como professa a doutrina majoritária ${ }^{81}$, natureza jurídica de direito privado, ainda que se reconheça que tal ramo é permeado por grande número de normas de ordem pública. No entanto, tal entendimento não é pacífico e não é de hoje que há quem defenda na doutrina nacional outros pensamentos acerca da natureza jurídica do Direito do Trabalho, como Cesarino Júnior, que estabeleceu uma terceira via, que não identifica o direito do trabalho nem como direito público, nem como direito privado, mas sim como direito social.

No entanto, ainda que se reconheça a preferência pela tese genial defendida por Cesarino Jr., optou-se por realizar esta pesquisa considerando a natureza jurídica privatística do direito do trabalho, afirmada pela formalização da relação de emprego por meio do contrato, por ser esta a doutrina mais aceita e difundida, merecendo assim os apontamentos críticos, já que dificulta a efetividade do conceito de trabalho decente.

No entanto, a análise pretendida considerará que mesmo a doutrina conservadora que adota a teoria privatística, não nega a enorme incidência de normas de ordem pública, imperativas.

As normas de ordem pública "são normas de aplicação imperativa que visam directa e essencialmente tutelar os interesses primordiais da colectividade" (COSTA, 2000, p. 473). Existem dois parâmetros de análise do conceito de ordem pública, a saber:

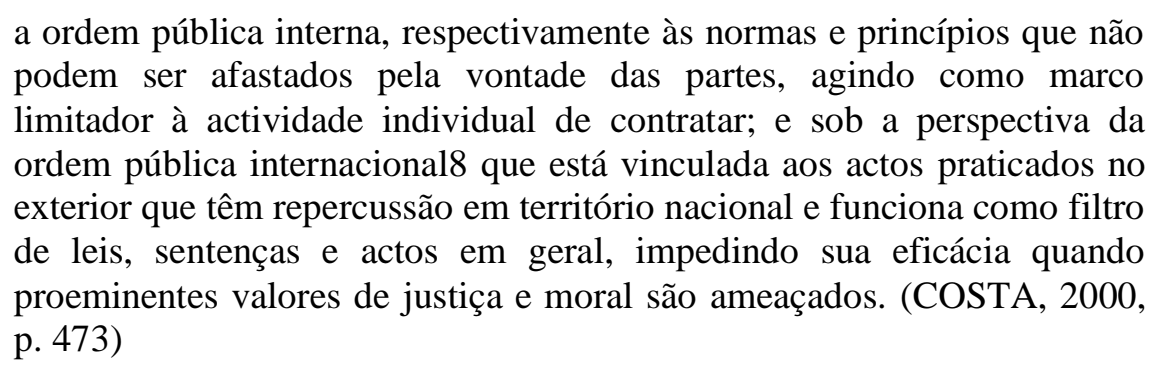
p. 473)

Assim, o extenso rol de normas de ordem pública contidos no Direito do Trabalho indicam claramente que o interesse relacionado ao contrato de emprego não se volta apenas às suas partes, ou seja, ao empregado e ao empregador, mas à toda coletividade, que é atingida pelos efeitos daquele pacto.

${ }^{81}$ Cf. Amauri Mascaro Nascimento, Sérgio Pinto Martins, etc. 
Essa pequena digressão importa na medida em que se reconheça o contrato de trabalho como instrumento sui generis, porque, ainda que detenha a estrutura basilar de contrato, se afasta na sequência, de sua concepção original civilista, de um dos elementos caracterizadores desse tipo de pacto, que é a manifestação espontânea e livre de duas ou mais partes. Além disso, como já afirmado, seus efeitos se fazem sentir não apenas por quem pactuou o contrato, mas pela coletividade, o que significa dizer que há um interesse público em manter o equilíbrio desse instrumento.

A relação de emprego é formalizada por um contrato que de fato não é construído pelas duas partes, partes essas que não detêm a mesma força e o mesmo empoderamento. Aliás, o direito do trabalho reconhece essa determinante intrínseca da relação de emprego, qual seja, que o trabalhador é hipossuficiente diante da força econômica e política do empregador.

O contrato de emprego, assim, já vem moldado pela parte verdadeiramente empoderada, ou seja, pelo empregador, e, quando muito, o empregado apenas o assina, cumprindo uma etapa formal daquele negócio jurídico, mas sem de fato ter oportunidade real de manifestar e equilibrar sua vontade frente à vontade do empregador.

Em uma sociedade que se organiza entorno do trabalho, e onde a maioria das pessoas atinge os bens necessários à vida por meio do trabalho, imaginar-se sem ele é uma das situações mais desesperadoras que o homem pode encontrar, porque significa negar-lhe a vivência, conduzir-lhe à sobrevivência, ou mesmo a condições que podem culminar na fatalidade, como os processos de violência.

Há forças externas que deslocam o trabalhador para o desemprego e para o trabalho precarizado, às quais ele não tem, na maioria das vezes, oportunidade de resistir, ainda mais se esse movimento de resistência se manifestar de maneira individual, contexto que dissipa concretamente a oposição oferecida, porque o embate de forças não é equilibrado.

Os fatores externos que induzem o trabalhador a aceitar uma relação de trabalho precarizada são o medo do desemprego, da perda da fonte de renda, a baixa estima fomentada pelo mercado, a relação social que se dá entorno do valor do trabalho, sujeito à distorções, todos elementos decorrentes do fato de que as necessidades vitais do trabalhador são preenchidas pela renda que ele obtém do trabalho. A vida nesse aspecto depende do trabalho, e, mesmo sob péssimas condições, é fundamental manter o acesso à vida.

À guisa de exemplo, atualmente, não é difícil encontrar distorções absurdas acerca do valor que o trabalho atinge na sociedade, a ponto de ser notoriamente mais fácil 
encontrar um novo posto no mercado de trabalho quando ainda se está empregado, porque significa que a mudança de emprego é uma opção do trabalhador, ao passo que se o trabalhador está desempregado, entra no jogo social não como alguém arrojado, mas como um perdedor.

A idéia do looser é calcada na cultura norte-americana do tempo é dinheiro. Quando não se está trabalhando, deixa-se de ganhar dinheiro, e o tempo gasto no consumo (paradoxalmente), além do valor que se dispendeu na compra, encerra o que se deixou de ganhar. Esse raciocínio culmina no propósito do made yorself, do faça você mesmo, atribuindo ao ser humano uma concepção de liberdade, que na realidade não se dá dessa forma. A condução da vida individual não é absolutamente livre, como se fosse possível tomar as decisões somente de acordo com os desejos e as vontades, como se as escolhas fossem pautadas apenas por fatores individuais e pessoais.

Ao contrário. Conforme aludido, há forças externas à vontade individual que são determinantes nas escolhas realizadas pelos homens, e que no mais das vezes se sobrepõem às opções subjetivas.

Tais fatos são conhecidos e reconhecidos no ambiente jurídico, o que não significa dizer que têm pautado muitas das decisões advindas do Poder Judiciário.

Acreditar que o trabalhador manifesta sua vontade porque assina ou anui ao contrato, é generalização por demais simplista e equivocada, porque desconsidera a realidade concreta que pressiona o indivíduo de maneira irresistível a aceitar condições de trabalho que não deseja.

Essa realidade impacta não apenas naquele trabalhador que assinou um contrato de emprego com condições leoninas, que não o teria feito se efetivamente tivesse liberdade na contratação, se não fosse empurrado para tais condições pelas forças alheias à sua vontade, mas também por aqueles trabalhadores que se sentem empregados, mas são classificados pelo direito como parasubordinados ou como autônomos.

O Poder Judiciário Trabalhista, inúmeras vezes, à margem das considerações aqui pugnadas, aplica ao contrato de emprego a mesma lógica civilista, ignorando que o fato jurídico que o gerou tem condição bastante diversa daquelas em que se baseiam as relações cíveis.

No acórdão referente ao processo n. 00483.2008.029.02.00-9, pertencente ao TRT $2^{\mathrm{a}}$ Região, pode-se denotar a tendência à aceitação de uma concepção civilista em uma relação jurídica que não se formou nesta condição. É o que se pode denotar dos trechos 
abaixo colacionado, que respeitam à fundamentação jurídica de um processo onde se pleiteava reconhecimento de vínculo empregatício:

\begin{abstract}
As transformações no cenário econômico e social dos últimos anos, manifestada por várias circunstâncias, entre as quais a descentralização produtiva, a inovação tecnológica e o aparecimento de novas profissões advindas da transição de uma economia industrial para uma economia pós-industrial ou de serviços, contribuíram para colocar em crise a tradicional dicotomia entre trabalho autônomo e trabalho subordinado. Daí ter surgido, a hipótese chamada de trabalho parasubordinado ou coordenado ou ainda como prefere a OIT: "relações de trabalho de ambiguidade objetiva". Trata-se de uma "zona cinzenta" entre a relação de trabalho e a relação de emprego. E para se tornar translúcida essa zona cinzenta há de se analisar a presença, em cada caso, dos requisitos legais constantes nos artigos $2^{\circ}$ e $3^{\circ}$ da CLT. Cabe verificar se configurada a situação em que o trabalhador, supostamente autônomo, mas habitualmente inserido na atividade produtiva alheia, a despeito de ter controle relativo sobre o próprio trabalho, não detém nenhum controle sobre a atividade econômica.
\end{abstract}

É esse um dos contextos que o conceito de trabalho decente da OIT pode ser refinado. Afirma o Órgão que trabalho decente é o "trabalho produtivo e adequadamente remunerado, exercido por homens e mulheres de todo o mundo em condições de liberdade, igualdade, segurança e dignidade, e livre de qualquer forma de discriminação". Ainda que não haja referência direta à questão da espécie de contrato que pauta a dignificação do trabalhador, o conceito é estruturado em quatro objetivos estratégicos, a saber: a promoção dos direitos fundamentais no trabalho; o emprego; a proteção social e fortalecimento do tripartismo e do diálogo social.

Como já analisado ${ }^{82}$, a OIT, acredita-se, não entende o termo emprego como trabalho subordinado regido por regras protetivas, mas sim como denominação genérica de trabalho. Como se pode denotar do julgado referido, dificilmente o trabalho decente é contemplado dentro de outra espécie de labor que não o emprego - subordinado e protegido pelo ordenamento jurídico.

Não há, a princípio, nenhum impedimento ao reconhecimento de trabalho decente em outras espécies de trabalho que não o emprego, mas é de se reconhecer que habitualmente é nesta espécie singular que o trabalhador encontra maior amparo legal à sua condição de hipossuficiência, daí o motivo da eleição do trabalho subordinado como melhor parâmetro para o trabalho decente.

\footnotetext{
${ }^{82}$ Vide capítulo 3 da tese.
} 
Via de regra, quando se aplica nas relações de trabalho (quer seja de emprego ou outra espécie) a lógica jurídica privatística, há um aviltamento da condição de hipossuficiência do trabalhador, que concretamente não tem opção, escolha, apenas anui às péssimas condições que lhe são impostas por forças externas à sua vontade e à sua humanidade.

Por isso, a regra do pacta sunt servanda deve ser aplicada com restrições aos contratos trabalhistas, como se pode observar da doutrina de Maurício Godinho Delgado, que, comentando a possibilidade de arbitragem na Direito do Trabalho, releva que sua estrutura principiológica se funda na hipossuficiência do trabalhador:

(...) De fato, a Lei n. ${ }^{\circ} 9.307$ parece querer conferir qualidades de coisa julgada material à decisão arbitral, mesmo em conflitos meramente interindividuais, excluindo, em consequiência, da apreciação judicial lesão ou ameaça a direitos trabalhistas que poderiam estar nele embutidas. Ainda que se considere superável tal dificuldade de compatibilização no âmbito do Direito Civil e Direito Comercial/Empresarial - onde vigora, como critério geral, o princípio da autonomia da vontade -, ela não parece passível de arrendamento no campo justrabalhista, em que os princípios nucleares são de natureza e direção sumamente distintas (DELGADO, 2008, p. 1453-1454).

A $7^{\mathrm{a}}$ Turma do $\mathrm{TST}^{83}$ adota a tese que a arbitragem é de possível, inclusive para a homologação da rescisão, documento este que permite a inserção de uma cláusula de quitação geral, onde o empregado abre mão de qualquer reclamação posterior contra a empresa. A notícia cotejada indica, dentre outros fundamentos trazidos pelo relator do julgado, que a arbitragem, como forma alternativa de solução de conflitos, exige adesão das partes - autonomia da vontade, pode-se deduzir; ademais, o relator do julgado manifesta uma lógica civilista, ao tratar o caso, que, crê-se, não respeita a estrutura jurídica oferecida à relação de emprego:

Há colegas que têm essa idéia de que nada no Direito do Trabalho pode ser negociado. Acredito realmente que há regras que não podem ser negociadas, como as processuais e as que estabelecem patamares mínimos para o salário ou piso da categoria e as normas de segurança do

83 Artigo divulgado em outubro de 2008 no Jornal do Commercio, seção Direito \& Justiça. 
trabalho. Mas em Direito Civil também tem determinadas normas que não são disponíveis.

Comentando a decisão do TST, um advogado de uma grande banca jurídica de São Paulo entende que a Corte Superior teve uma posição acertada no caso por respeitar a autonomia da vontade das partes:

a decisão do TST é positiva, porque assegura a autonomia da vontade, pela qual tanto o trabalhador como empregador podem optar por qual tipo de justiça adotar. "Todas as questões podem ser decididas via a arbitragem, inclusive aquelas relativas ao dano moral, acidente de trabalho. O procedimento arbitral tem o prazo máximo de 6 meses para ser cumprido, mas às vezes a questão é solucionada em duas audiências", enfatizou o especialista.

O principal fundamento a ser discutido nesta questão é se o trabalhador tinha consciência do significado da arbitragem como meio de solução de conflito, e se ao acatar essa forma de resolução de lides, teve oportunidade real de manifestar sua vontade, ou seja, se sabia o que é e para que serve o tribunal arbitral e se ao assinar o contrato de trabalho teve oportunidade de ler e entender o documento; além disso, se teve igual oportunidade de negar-se a anuir à cláusula de arbitragem sem correr risco de perder a vaga de emprego ou ser dispensado.

Essa é a primeira reflexão que deveria ser feita, e pode-se imaginar que, na realidade, muito poucos empregados teriam essa liberdade concretamente; o contrato de trabalho é caracterizado por encerar partes desiguais em empoderamento, daí porque o princípio protetor é basilar neste ramo jurídico, moldando toda a sua estrutura e também motivo pelo qual a relação de emprego jamais poderá ser tratada pelo Direito Civil. São ramos de natureza distintas, voltados para a solução de problemas distintos, gerados em relações sociais também distintas, com características peculiares.

Neste sentido, não basta que a OIT propugne um conceito utilizando apenas o termo emprego, que tem significado específico no direito (trabalho subordinado) em diversos Estados; o Órgão aplicaria mais eficácia ao conceito que criou se, nas suas ações, nos projetos, pesquisas e material didático fosse mais incisivo na defesa do conteúdo específico do termo, ou seja, no reconhecimento de que o trabalho subordinado, por toda significância jurídica que detém (subordinado, protegido, limitado quanto à autonomia da vontade do trabalhador), é o mais adequado na realização do trabalho decente. 


\subsubsection{Minimização de direitos}

À OIT é atribuída a criação e a promoção do conceito de trabalho decente, cuja autoria é de seu então Diretor-Geral Juan Somavia. Este conceito foi expandido e desenvolvido por meio de outros doutrinadores e pesquisadores em trabalhos realizados por aquele Órgão. Neste sentido, destaca-se o artigo de Dharam Ghai ${ }^{84}$.

Ghai indicadas alguns elementos de caracterização do trabalho decente, como a proteção contra acidentes, contra doenças, contra más condições de trabalho, contra jornadas excessivas, dentre outras; ocorre que essa proteção ao trabalhador só se manifesta no Brasil por meio de específico contrato de trabalho, que é o emprego.

Os demais contratos de trabalho verificados no ordenamento jurídico não foram criados a partir dos mesmos fatos sociais, nem têm a mesma estrutura principiológica do Direito do Trabalho, e essa distinção é determinante na proteção do trabalhador. Senão vejamos.

O único contrato de trabalho que é moldado a partir das características do trabalho subordinado e habitual, considerando a luta de classes e o conflito, portanto, entre capital e trabalho, é o contrato de emprego. A sua diferença com os demais contratos se dá especialmente por conta da aplicação do princípio protetor entorno dessa modalidade de pactuação, princípio este que garante ao trabalhador condições, ainda que se não ideal, digna de trabalho.

O princípio protetor é conceituado por Godinho Delgado como informativo de que o Direito do Trabalho:

estrutura em seu interior, com suas regras, institutos, princípios e presunções próprias, uma teia de proteção à parte hipossuficiente na relação empregatícia - o obreiro -, visando retificar (ou atenuar), no plano jurídico, o desequilíbrio inerente ao plano fático do contrato de trabalho.

Assim, o princípio é garantia de que o trabalhador encontrará o amparo necessário para garantir que sua exploração não extrapole os limites da civilidade. Ainda, como já se

\footnotetext{
${ }^{84}$ Conferir as especificações no capítulo 3 do vertente trabalho.
} 
indicou, que o princípio protetor não seja garantia absoluta de que o trabalhador não será explorado, estabelece limites à falta de autonomia da vontade real do trabalhador e à autonomia real do empregador, fazendo com que, no campo jurídico, o primeiro possa minimamente se equiparar em força dentro do contrato com o segundo, por que a norma o alça na linha do empoderamento. O princípio protetor, se pode defender, é o instrumento jurídico que conecta o trabalhador na busca da igualdade material.

Daí porque aqui se defende a tese de que é o contrato de emprego que pode incorporar a lógica do trabalho decente. O emprego é de fato instituto jurídico que agrupa as diversas formas de proteção do trabalhador, como garantias salariais, limites de jornada e do poder diretivo, regras de segurança, estabilidades, etc. Inclusive essa proposta tem base integralmente no princípio protetor, sendo ele a origem de onde advêm os outros princípios protetivos, como o princípio do in dubio pro operário, o princípio da aplicação da norma mais favorável ao trabalhador, o princípio da aplicação da condição mais benéfica, o princípio da primazia da realidade (contrato-realidade), e o princípio da irrenunciabilidade dos direitos.

Destarte, um conceito de trabalho decente, a fim de que seja eficaz, deve estar em consonância com a proteção do trabalhador hipossuficiente, e, se uma das melhores alternativas é inseri-lo no mercado a partir do contrato que agrupe a maior quantidade de normas protetivas, deve fazê-lo.

A eleição do contrato de emprego, formal, subordinado e recheado de normas de proteção imperativas advindas do Estado, que intervém nessa relação privada com o intuito de estabelecer minimamente um equilíbrio entre as partes que o compõe, se dá na medida em que ele encerra a melhor possibilidade de proteção oferecida pelo ordenamento jurídico.

Importa salientar que o nome que se atribui a essa forma de contratação (emprego, como no Brasil) não importa, mas sim o que é de extrema relevância é seu significado e suas características de concreta e vasta proteção, o que resolve o problema de compatibilização entre os variados sistemas normativos existentes.

O conceito de trabalho decente da OIT não conduz ao propósito de estabelecer, preferir ou ainda reconhecer que a melhor forma de contratação é o emprego; alude ao trabalho produtivo e adequadamente remunerado, exercido por homens e mulheres de todo o mundo em condições de liberdade, igualdade, segurança e dignidade, e livre de qualquer forma de discriminação, mas não diz qual forma deve ser a mais adequada. 
Relegar às partes essa tarefa, de escolha da melhor forma de contratação, deixa a oportunidade de precarização do trabalho, pois por óbvio que quem lucra com a exploração do trabalho alheio não irá optar, podendo preferir, por um contrato que impõe mais limitações à sua vontade que outros menos incisivo.

Além disso, um conceito de trabalho decente que inspire inclusive os Poderes Estatais na implementação de um contrato que aufira maior proteção ao trabalhador é sinônimo de efetividade na defesa de melhores condições de trabalho.

O conceito da OIT de trabalho decente não se encerra, como já aludido, na definição que o órgão atribui ao termo, mas é complementada por diversos estudiosos subsidiados pelo Órgão, que expandem e debatem o conceito, atribuindo-lhe significados mais específicos.

Assim, apesar de ter como um de seus pilares o emprego, conforme as doutrinas que complementam o conceito, subsidiadas pelo próprio Organismo Internacional, o que, subentende-se, se tornam chanceladas pelo Órgão, emprego significa trabalho, como gênero da categoria, e não espécie, com significado específico de trabalho remunerado, subordinado e protegido.

Portanto, há de se salientar que, quando a OIT propaga esta idéia, abre campo para a flexibilização do Direito do Trabalho, passando a idéia que qualquer forma de trabalho possibilita a realização de trabalho decente, o que não se mostra na realidade, pelos motivos acima expostos.

A defesa de que o emprego é a forma de contratação que mais reflete os ideais de dignidade acarretaria a implementação de ações efetivas que imprimiriam, por sua vez, maior eficácia ao termo, como por exemplo alterações legislativas nos países que internalizam as orientações da OIT, políticas públicas de inclusão pelo emprego, dentre outros movimentos que concretizam melhores condições ao trabalhador.

O intuito de uma ação de promoção da forma de contratação mais protetiva é uma das possibilidades de evitar um movimento que desconstrói em grande medida a luta travada historicamente pelos trabalhadores, de regulamentação legal de seu contrato a fim de melhoria e garantia de condições de trabalho mais adequadas. As políticas neoliberais de desregulamentação do contrato de trabalho impõem ao trabalhador grandes perdas, como a possibilidade de extensão da jornada de trabalho, ainda que mediante remuneração adicional. Afinal, se a limitação da jornada de trabalho surgiu da necessidade de descanso do trabalhador, inclusive para fins de maior segurança no trabalho, a mera atribuição de remuneração não tem o condão de afastar os malefícios físicos e psicológicos que o 
empregado sofre com as extensas horas de trabalho.

Vale trazer a diferença entre flexibilização e desregulamentação. Para Costa, a flexibilização é:

o instrumento ideológico liberal e pragmático de que vem se servindo os países de economia de mercado, para que as empresas possam contar com mecanismos capazes de compatibilizar seus interesses e os dos seus trabalhadores, tendo em vista a conjuntura mundial, caracterizada pelas rápidas flutuações do sistema econômico, pelo aparecimento de novas tecnologias e outros fatores que exigem ajustes inadiáveis (1992, p. 779).

Arnaldo Süssekind (1996) reforça a distinção entre os dois institutos, informando que a desregulamentação consistiria na retirada total da proteção estatal ao trabalhador permitindo a autonomia privada, individual ou coletiva, e que a flexibilização pressupõe intervenção estatal, ainda que básica, com normas gerais abaixo das quais não se pode conceber a vida do trabalhador com dignidade.

A desregulamentação seria, assim, o caminho no qual desagua a flexibilização. Senão vejamos. Com a flexibilização das normas de proteção, a política de desregulamentação pode se instaurar, na medida em que enfraquece o movimento dos trabalhadores e retira a intervenção do Estado nos contratos, admitindo-se assim o retorno à plena autonomia da vontade das partes:

Todos esses grupos precisam de economias desregulamentadas, ou seja, sem normas constrangedoras da sua mobilidade. Não há, porém, desregulamentação em abstrato. No lugar das normas abandonadas - boas ou más - não fica um vazio. (...) Se o governo é dispensado de governar a economia, os investidores internacionais fazem isso por ele. (BENJAMIN, 1998, p. 32)

Samuel Gueiros Júnior e Aírton da Silva Lopes, de forma esclarecedora, indicam que neste processo o trabalhador e o Estado perdem sua força política, porque há uma clara retração do espaço público necessário para o enfrentamento das grandes questões que se colocam à população:

O cenário é de um enfraquecimento e total submissão do Trabalho e do Estado, que se desqualificam como atores de um espaço político. Mantida a diretriz da desregulamentação e flexibilização, sinaliza-se para uma arena sem conflitos e o tripartismo caminha para a obsolescência. Inexistindo o conflito, e a intervenção estatal, operando de forma meramente simbólica, esgarçam-se as interfaces entre a inspeção do trabalho e a sociedade, correndo-se o risco de um processo autofágico. 
A minimização dos direitos dos trabalhadores acarreta, como já se conhece, um retorno indesejável às condições de trabalho dos idos da revolução industrial, onde a autonomia da vontade era o molde responsável pelas normas que regeriam a relação de emprego, o que notoriamente acarretou imensos males, que, se destaque, atingiu não apenas o trabalhador individualmente, mas toda a coletividade, que sofreu os efeitos perversos da falta de equidade entre empregado e empregador na contratação.

Esses elementos que compõem as políticas liberais deságuam em um retorno ao passado, onde as pessoas que dependiam de seu trabalho para sobreviver amargavam toda sorte de injustiças e péssimas condições de labor, absolutamente inadequadas ao ser humano.

Não é exagero atribuir à flexibilização ou desregulamentação o retorno à condições que se imaginava historicamente superadas em relação a existência de um conjunto de regras que regulamentam e limitam a autonomia da vontade para garantir condições minimamente adequadas ao trabalhador. Independente do sistema de regramento jurídico que cada Estado atribui aos seus internos, pode-se observar o crescimento contínuo de "bolsões de trabalho" nos países subdesenvolvidos.

Naomi Klein, no seu livro Sem Logo, explica o movimento das chamadas supermarcas, que é exemplar ilustração de como a precarização do trabalho, a transferência de responsabilidade de quem se serve do trabalho de outrem, para outra empresa que lucra com a alocação da mão-de-obra, útil quanto à energia desgastada, mas incômoda quando titular de direitos sociais, se transforma em um processo de espoliação do trabalhador.

As supermarcas são as empresas multinacionais que criam marcas mundialmente poderosas, transformadas no mais forte objeto dessas organizações, que se desassociam da produção focando seu objetivo social no marketing e nos projetos de produtos, relegando a produção à outras empresas, que alocam a mão-de-obra. No à toa, este processo poderia ser chamado de terceirização de mão-de-obra globalizada. Uma empresa, forte e poderosa, quer obter a energia dos trabalhadores, mas não quer estar associada com a responsabilidade social que isto traduz, e, para tanto, contrata outras empresas que se responsabilizam - teoricamente, pois a prática demonstra as inúmeras ilicitudes que envolvem este método - pela parte incômoda do procedimento.

A Autora inicia seu relato sobre a Fábrica Descartada indicando a visão de um empresário ligado à marca Levis: 
Nosso plano estratégico na América do Norte é focalizar intensamente o gerenciamento de marca, o marketing e o projeto de produto como um meio de atender às necessidades e desejos de roupas informais dos consumidores. Mudar uma parcela significativa de nossa fabricação de mercados americanos e canadenses para terceiros em todo o mundo dará à empresa maior flexibilidade para alocar recursos e capital a suas marcas. Esses passos são essenciais se quisermos continuar competitivos. John Ermatinger, presidente da divisão Levi Strauss Américas, explicando a decisão da empresa de fechar 22 fábricas e demitir 13.000 trabalhadores norte-americanos entre novembro de 1997 e fevereiro de 1999. (KLEIN, 2002, P. 219)

Resta claro que "terceiros em todo mundo" significa trabalhadores de países fragilizados política e economicamente, que dependem em grande parte de investimento externo para o desenvolvimento econômico, e, num círculo retroalimentador, abrem o mercado interno com inúmeras vantagens para tais investidores. As empresas aproveitam desse quadro generoso, e impõem ainda mais condições para sua fixação no país, que muitas vezes incluem a flexibilização do direito do trabalho, a fim de não se verem oneradas pelo custo da mão-de-obra, possibilitando deste modo uma enorme concentração de riquezas, como se fossem - e são hoje em dia - zonas não apenas de livre comércio, mas de livre exploração dos trabalhadores.

Ora, está aí claramente tipificado o processo de terceirização em proporção globalizada. O capitalismo globalizado acontece a partir das grandes corporações. São bases da globalização: 1) as perspectivas políticas da democracia liberal, 2) a economia de mercado e 3) o neoliberalismo.

O primeiro item, qual seja, a democracia liberal, se reflete num imenso processo de privatização do público, onde o espaço público de discussão política cada vez mais se vê esvaziado, e, pior, diminuído. O cidadão passa a ser paulatinamente transformado em "o consumidor", que só passa a ter representatividade na medida em que consome.

Otávio Ianni se refere às metamorfoses, da democracia em mercado, representada pela democracia liberal, do cidadão em consumidor e das ideologias em mercadorias. Essas perspectivas representam o neoliberalismo, sistema que possibilita a globalização como critério civilizatório de ocidentalização do mundo.

Conrado Vieira, citando José Monserrat Filho, também enfatiza a característica de fenômeno privado da globalização, quando este último afirma que os interesses das empresas privadas internacionais "constituem os principais propulsores e beneficiários da globalização econômica", e que "a globalização acelerada da vida 
econômica, social, política e cultural de todos ou de quase todos os países, nações e povos vem beneficiando, em primeiro lugar, o interesse privado, uma espécie de privatização do planeta, ainda sem a indispensável contrapartida de benefícios públicos abrangentes." No entanto, o Autor ressalta que, “conquanto prevaleça seu enfoque privado, detém também componente de caráter público, vez que as decisões públicas, de fato, podem facilitar menos ou mais o ingresso dela, globalização, nos territórios nacionais." (BASSO, 1997, p. 85)

Nesse sentido, o reflexo na seara trabalhista da política de estabilização econômica, eficiência administrativa, desenvolvimento do mercado de trabalho, e todas as ventiladas benesses das políticas neoliberais, é a minimização dos direitos do trabalhador. Os "milagres" atribuídos à minimização das normas trabalhistas, como a abertura de novas vagas de trabalho, a retirada do engessamento das relações de trabalho por meio de normas excessivamente protetivas, a maior autonomia das partes, a autonomia coletiva do trabalho por meio de representação sindical, inserção de novas tecnologias na produção, etc., alardeados pelos defensores dessas políticas, acabam resultando na possibilidade de alteração in pejus das condições de trabalho, e esmorecendo a segurança jurídica advinda do princípio protetor, contrapondo-se à própria estrutura que dá autonomia ao Direito do Trabalho como ramo jurídico.

O que se observa é que não há equilíbrio entre inovações necessárias nas regras trabalhistas e proteção do trabalhador na inserção dessas novas políticas; o que sobressalta é que o interesse do capital na acumulação de riquezas vem afetando sensivelmente o mundo do trabalho, a ponto de conquistas históricas dos trabalhadores estarem sendo constantemente ameaçadas e repensadas, em detrimento do trabalhador

Um conceito de trabalho decente que se pretende eficaz deve fortalecer a proteção sobre o trabalhador, valorizando e promovendo uma forma de contratação que efetivamente estabeleça limites bastante claros à autonomia privado do empregador, considerando portanto o desequilíbrio de forças entre as partes que compõe a relação de emprego.

Interessante verificar que o número de ações trabalhistas propostas por empregados formalizados e contratados diretamente pelo tomador de serviços diminuiu em $21 \%$ nos últimos nove anos, enquanto as ações promovidas por empregados terceirizados que pedem a responsabilização subsidiária da empresa tomadora do serviço cresceu $71 \%$, relativo ao 
mesmo período ${ }^{85}$. Aduz ainda a referida pesquisa que o levantamento foi realizado a a partir de dados de 71 grandes empresas, de nove ramos de atividade diferentes, e que juntas possuem 815 mil empregados. A soma do faturamento bruto destas companhias representam 27\% do Produto Interno Bruto (PIB) do país. Participaram da pesquisa empresas como a Basf, a CPFL Energia, os Correios, a TIM, a Companhia Siderúrgica Nacional (CSN), Gerdau, Votorantim, Arcelor Mittal, Alstom, Boticário, Fundação Petros, dentre outras.

A leitura que se pode fazer da referida pesquisa, obviamente, não é a de que os empregados formais não sofrem danos trabalhistas, mas sim que houve efetivamente uma diminuição dos postos formais de trabalho. No entanto, essa diminuição não é equivalente à adesão maciça de muitas empresas à terceirização, e se pode concluir que os contratos indiretos sofrem ainda mais danos aos direitos trabalhistas que os contratados formais; aliás, a pesquisa aludida no capítulo que trata da exclusão pelo trabalho degradante já demonstrava que é o terceirizado que ocupa as piores vagas de trabalho, nos piores ambientes e com as piores condições, daí a importância de que o conceito de trabalho decente fomente a inclusão pelo trabalho digno através de contratos que protejam o trabalhador, por serem normatizados com normas imperativas que limitem a autonomia privada da vontade da parte mais empoderada, o empregador.

A pesquisa ainda dá conta que essa minimização de direitos através da terceirização atinge também o setor público, indicando assim que a Administração Pública, que deveria ser paradigma na atenção às normas trabalhistas e à proteção do trabalhador, também precariza o trabalho e descumpre a legislação. É o que se depreende do quanto exposto pelo Magistrado entrevistado:

Na vara trabalhista onde Neiva atua, há principalmente casos que
envolvem empresas contratadas pelo próprio governo. "Muitas
prestadoras de serviços terceirizados que ganham processos de licitação
por oferecer o menor valor pelo serviço, não têm condições de manter
esse contrato. Então quem paga novamente a conta desses funcionários é
próprio governo, com dinheiro público", afirma o magistrado. Na opinião
do juiz, a melhor solução para esse impasse seria encerrar com a
terceirização nos contratos públicos. "A conta desses contratos de

${ }^{85}$ Pesquisa Brasileira em Gestão do Capital Humano, realizada pela Sextante Brasil, conforme noticiado no Jornal Valor $\quad$ Econômico. $\quad$ Disponível em <http://www.valoronline.com.br/?impresso/legislacao_\&_tributos/197/5830651/acao-por-terceirizacao-ecrescente>. Acesso em 22.09.09. 
terceirização se torna muito mais alta, do que manter funcionários concursados", afirma.

O conceito introduzido pela OIT foi debatido em estudo promovido pelo Órgão, que culminou no entendimento de Cristian Ramos sobre a relação entre trabalho decente e governabilidade democrática, conforme se pode constatar anteriormente.

Ocorre que a governabilidade democrática se baseia na doutrina gerada pelo que se conhece como Consenso de Washington, cuja agenda seria teoricamente amalgamar na administração dos recursos públicos, técnicas não apenas de administração pública, mas também de administração de entidades privadas, supostamente para fins de desenvolvimento com equidade e sustentabilidade, através da capacidade dos governos de planejar, formular e implementar políticas e cumprir funções; enfim, o fenômeno chamado "boa governança".

Como já se pode aduzir anteriormente, a boa governança é inspirada nas políticas neoliberais, que impingiram aos Direitos Sociais enormes perdas por meio da flexibilização e da desregulamentação.

Na prática, a boa governança, política instituída pelo Consenso, pretende organizar os recursos públicos com a mesma (pretensa) eficiência do setor privado, evitando gastos que não tenham sido previstos, sob pena de responsabilização do administrador público. Para tanto, é preciso uma gestão levada à cabo por todos os poderes do Estado (Executivo, Legislativo e Judiciário), cada um atuando dentro de sua seara para consecução do fim comum.

A boa governança, nos dizeres de Christoph Eberhard, pode ser analisada a partir de duas possibilidades:

O desejo pela boa "governança global" nesses campos é, na melhor das hipóteses, um ideal que buscamos atingir ou, na pior das hipóteses, uma ideologia de imposição de agenda dos países mais poderosos sobre os demais, utilizando o disfarce das soluções universais para problemas globais (2008, p. 7).

A boa governança pode ser um ideal na medida em que representa a máxima da eficiência, ou seja, produzir os maiores resultados, com os menores recursos sem introduzir qualquer excesso no orçamento. Daí surge a primeira crítica à boa governança. O Estado tem objetivos bastante diversos de um ente privado como a empresa, e a lógica de 
administração não pode evidentemente ser aplicada a um e a outra da mesma maneira, já que se trata de institutos com objetivos bastante diversos.

É claro que não se defende aqui que a gestão pública não deve procurar atingir os maiores graus de eficiência, mas esse objetivo não deve ser perseguido em detrimento de ações estatais essenciais, e deve ser aplicado com coerência em sua lógica. Mas como afirmado, não há razoabilidade em exigir do Estado gestão como a de uma empresa privada, porque aquele visa o cumprimento de outras necessidades, que não prioritariamente a atividade lucrativa, e incorporar este discurso na gestão pública tem como efeito perverso a diminuição de direitos e políticas públicas sociais, na medida em que a realização da Justiça Social exige gasto público.

A discussão acerca das gerações de direitos humanos, que os classifica em direitos de primeira geração (civis e políticos), direitos de segunda geração (sociais, econômicos e culturais), etc., se arrasta no sentido de indicar que os primeiros são direitos que não exigem grandes investimentos do Estado, enquanto os segundos exigem altas somas cujo pagamento se estende no tempo. Tal debate poderia já ter sido superado, na medida em que parte da doutrina, destacando-se aí o livro The cost of rights, de Holmes e Sunstein, onde existe vasta fundamentação indicando que qualquer direito exige custos, inclusive os de primeira geração.

Daí se manifesta a ideologia que tece os contornos da política de boa governança, que resultam na fragilização dos direitos sociais (e das políticas públicas voltadas para o social). Essa realidade se converte na flexibilização e na desregulamentação trabalhista, manifestada inclusive quando a Administração Pública atua como empregador.

O Estado privilegia constitucionalmente princípios públicos como o da legalidade e da moralidade (art. 37 da $\mathrm{CF} / 88$ ), sendo certo que, para garantir esses dois postulados, instituiu a exigência de concurso como parte de seleção para a ocupação de seu quadro de servidores, sejam estatutários ou celetista.

Pois bem. Quando o Estado contrata em regime de urgência ou qualquer das outras formas de contratação excepcionais ao concurso público, deve obviamente seguir aos mesmos princípios que regem a regra geral. No entanto, o que se pode entrever é que a lógica da boa governança se mostra muita mais como fator ideológico, assentado no intuito de fazer prevalecer uma política neoliberal, que, em termos de direitos sociais, é desastrosa.

Tendo o Estado a opção de contratação por emergência, capta trabalhadores cujos contratos são precarizado, tendo redução nos direitos e garantias que lhes eram devidos. 
Esse trabalhador, muitas vezes, como notoriamente se faz saber, acabam por ser incorporados pela Administração Pública, informalmente. Entram na Administração por meio de contrato provisório que acaba se estendendo por anos, tornando-se assim irregular. Passam anos trabalhando sem regularidade para o Estado e, em dado momento, percebemse desamparados socialmente.

Isso porque, após trabalharem anos no mesmo local, recebendo salário e ordens diretas, não são reconhecidos pelo Empregador (Estado) como empregados, e buscam a tutela do Poder Judiciário para ter o reconhecimento de vínculo de emprego judicialmente.

Note-se que, de fato, não há lei específica que regulamente a terceirização de trabalho no Brasil, e o TST, por meio de súmula, acaba legislando sobre o tema, ainda que não tenha qualquer competência legal para fazê-lo. A Súmula 331 do TST acabou se tornando referência sobre o assunto tendo-lhe atribuída, na prática, força de lei, que não é de fato.

Aduz a Súmula 331 do Tribunal Superior do Trabalho que:

CONTRATAÇÃO DE PRESTAÇÃO DE SERVIÇOS - LEGALIDADE - INCISO IV ALTERADO PELA RESOLUÇÃO 96/2000, DJ 18.9.2000.

I - A contratação de trabalhadores por empresa interposta é ilegal, formando-se o vínculo diretamente com o tomador dos serviços, salvo no caso de trabalho temporário (Lei ${ }^{\circ}$ 6.019, de 3.1.1974).

II - A contratação irregular de trabalhador, mediante empresa interposta, não gera vínculo de emprego com os órgãos da administração pública direta, indireta ou fundacional (art. 37, II, da CF/88). (g.n.)

III - Não forma vínculo de emprego com o tomador a contratação de serviços de vigilância (Lei $\mathrm{n}^{\mathrm{o}} 7.102$, de 20.6.1983) e de conservação e limpeza, bem como a de serviços especializados ligados à atividade-meio do tomador, desde que inexistente a pessoalidade e a subordinação direita.

IV - O inadimplemento das obrigações trabalhistas, por parte do empregador, implica a responsabilidade subsidiária do tomador dos serviços, quanto àquelas obrigações, inclusive quanto aos órgãos da administração direta, das autarquias, das fundações públicas, das empresas públicas e das sociedades de economia mista, desde que hajam participado da relação processual e constem também do título executivo judicial (art. 71 da Lei no 8.666/93, de 21.6.1993).

O TST mantém, assim, entendimento sumulado que, por conta da falta de regulamentação legislativa da matéria, restou adotada no ambiente jurídico como se lei fosse, sendo seguida fielmente dentro e fora do Poder Judiciário. Crê-se que o entendimento adotado pelo TST é uma afronta à dignidade do trabalhador, em especial no 
que tange ao afastamento da responsabilidade do administrador público. A bem da verdade, a Súmula 331 se tornou uma chancela do Poder Judiciário à gestão irresponsável, pois o administrador público, que é o competente para abertura de concursos e preenchimento das vagas públicas de acordo com a lei, contrata trabalhadores de maneira irregular, e, mesmo processado, não sofre qualquer tipo de responsabilização, tendo o trabalhador, que foi espoliado de seus direitos, que arcar com o prejuízo sofrido por conta daquela má gestão.

Um conceito de trabalho decente que rechace a contratação intermediada, combatendo a terceirização, serve inclusive de parâmetro de interpretação na aplicação da lei, e viabilizaria mais sentenças como a abaixo colacionada ${ }^{86}$, que afasta a aplicação da Súmula 331 em respeito à dignidade do trabalhador:

O princípio da exigência do ingresso por concurso público é norma de ordem pública a nível constitucional, e portanto, prima facie, impossível de ser deixada de lado para ser reconhecido o vínculo.

Todavia, a Constituição Federal de 1988 estabelece como princípio básico que a administração deverá obedecer os princípios de legalidade, impessoalidade, moralidade, e publicidade. A legalidade segundo ensina o saudoso Hely Lopes Meirelles, significa o princípio de que o administrador público está, em toda a sua atividade funcional, sujeito ao mandamento da lei e às exigências do bem comum, e deles não pode se afastar ou desviar. A lição ressalta que todo o ato administrativo está sujeito ao império da lei, mas a colocação do mestre sobre as exigências do bem comum não é gratuita, posto que somente o legal não atende à finalidade dos atos da administração, mas junta-se ao requisito da moralidade, juntando-se ao honesto e conveniente (Direito Administrativo Brasileiro, pág. 82/83, Malheiros, 22ª edição): “ Cumprir simplesmente a lei na frieza de seu texto não é o mesmo que atendê-la na sua letra e no seu espírito. A Administração, por isso, deve ser orientada pelos princípios do Direito e da Moral, para que ao legal se ajunte o honesto e o conveniente aos interesses sociais. Desses princípios é que o Direito Público extraiu e sistematizou a teoria da moralidade administrativa ..." E conclui expondo o princípio da moralidade: “ A moralidade administrativa constitui, hoje em dia, pressuposto de validade de todo o ato da administração pública"

\footnotetext{
${ }^{86}$ Fundamentos utilizados na decisão prolata pelo Juiz Firmino Alves Lima, da $4^{\text {a }}$ Vara do Trabalho de Jundiaí, processo no 1.794/98, concedendo o vínculo de emprego com a Administração Pública Direta.
} 
Assim, o magistrado indica claramente que uma interpretação não pode, de maneira leviana, atribuir significados que juridicamente não se sustentam para atingir uma finalidade desviada da idéia de bem comum, a fim de fazer valer uma vontade que não está expressa no ordenamento jurídico, mas sim no impulso do mal administrador público:

O ponto de equilíbrio com a legalidade é a moralidade, pois nem tudo que é jurídico é honesto "non omne quod licet honestum est", e a busca do bem comum é o inquestionável objetivo da administração pública e fundamento primordial do Estado. Não é o conceito de moral comum, mas moral administrativa, a qual, antes de tudo, se volta ao bem comum. A exigência do concurso público é uma formalidade prevista na carta política para obter-se eficiência, moralidade e aperfeiçoamento do serviço público, principalmente para evitar-se os descalabros da administração com o dinheiro alheio, em entupir repartições públicas de afilhados políticos, em troca de votos.

Como forma, não afeta a existência do ato, mas sim, pressupõe o reconhecimento de sua validade. O concurso é voltado ao sentido de que a administração se beneficie dele, e não de sua falta, posto que é beneficiar-se de sua própria torpeza, de um modo legalizando o que não fez legalmente, atentando contra os princípios constitucionais acima citados da administração pública.

Ainda manifesta a colacionada sentença o desvio de fundamentação da referida súmula ao indicar que a Administração não deve ser condenada ao reconhecimento de vínculo trabalhista se não houve concurso público:

Se por um lado, a imoralidade existe com a falta de respeito ao prestador, cujo respeito aos direitos fundamentais do trabalho o direito deve proteger, mais ainda, a conduta ilícita da $3^{\text {a }}$ Reclamada aflora como cristalina demonstração de ato administrativo ilegal, pois caminha ao mais completo arrepio dos preceitos legais trabalhistas, contratando em situação irregular. A nulidade seria patente ante ao referido dispositivo constitucional, mas declarar-se a inexistência de efeitos da relação jurídica havida entre as partes é impossível ante à consumação das contraprestações contratuais. O primeiro ponto que incide a ilegalidade, é o Princípio Fundamental de Organização do Estado Brasileiro inscrito na Constituição Federal, em seu artigo $1^{\circ}$, inciso IV, o qual é bem claro, verbis:

"Art. 1". A República Federativa do Brasil, formada pela União indissolúvel dos Estados e Municípios e do Distrito Federal, constitui-se em Estado Democrático de Direito e tem como fundamentos:

I- a soberania

II - a cidadania

III - a dignidade da pessoa humana

IV - os valores sociais do trabalho e da livre iniciativa (g.n.)

V- o pluralismo político 
Constitui princípio fundamental da nação os valores sociais do trabalho, motivo pelo qual este não pode ser visto como um objeto de uma obrigação qualquer, mas sim, com circunstâncias especiais, muito mais ainda o trabalho para o ente público. E também como princípio fundamental da Constituição, é norma que suplanta em importância, toda e qualquer outra norma de igual valor, cuja aplicação deverá ser norteada pelos princípios fundamentais de organização do Estado, e sendo o valor social do trabalho um destes, a interpretação da norma contida no artigo 37, II, deverá se adequar aos princípios básicos da própria $\mathrm{CF} / 88$.

Destarte, um conceito de trabalho decente deve respeitar o fato de que qualquer ação realizada tem por objetivo a satisfação da vida humana, e que os motivos econômicos e financeiros que moldam esta ou aquela ação política (termo aqui utilizado em seu sentido genérico) deve ter sempre a finalidade de realização do bem-estar humano.

Acerta a OIT quando indica na Declaração de Filadélfia (1944) elementos que balizam a interpretação do conceito de trabalho decente, estabelecendo como princípio fundamental na qual "repousa a Organização" que o trabalho não é mercadoria, e que a experiência demonstra ser sobre a justiça social que a paz se assenta. Mas talvez a orientação mais importante que surja desta norma consiste na clara posição de que todos os seres humanos têm o direito de assegurar o bem-estar material e o desenvolvimento espiritual dentro da liberdade e da dignidade, da tranqüilidade econômica e com as mesmas possibilidades, e que a realização de condições que permitam o exercício de tal direito deve constituir o principal objetivo de qualquer política nacional ou internacional, indicando ainda que qualquer plano ou medida, especialmente os econômicos e financeiros, devem ser considerados sob esse ponto de vista e somente aceitos, quando favorecerem, e não entravarem, a realização desse objetivo principal.

Aí reside elemento fundamental do conceito, pois o trabalho decente só pode ser obtido a partir de um labor que se funde nessa perspectiva, onde a condição humana não seja subtraída em prol de ajustes, planos e medidas econômicas e financeiras que não promovam a justiça social. Ao contrário, as medidas que se formarem sem estarem em plena consonância com a realização da dignidade humana devem ser afastadas e repensadas. 


\subsubsection{Espaços Públicos e ampliação da democracia participativa.}

Neste tópico, importa salientar a importância dos espaços públicos e da democracia participativa na eficácia do conceito de trabalho decente. Qualquer luta social deve ser precedida de esclarecimentos e debates junto à população, para que as importantes questões do mundo do trabalho, tema desta pesquisa, sejam relacionadas e argumentadas pelos atores sociais que mais serão atingidos, ou seja, os trabalhadores e a comunidade onde estão inseridos, já que os efeitos da relação de emprego se fazem sentir além das partes que a realizam.

Daí advém a enorme importância do fomento dos espaços públicos, quer sejam estatais ou não.

Espaços públicos são espaços físicos de convivência da comunidade, que promova o encontro da população para o conhecimento e debate das questões de interesse comunitário. Nos dizeres de Zygmunt Bauman:

Um espaço é público à medida que permite o acesso de homens e
mulheres sem que precisem ser previamente selecionados. Nenhum passe
é exigido, e não se registram entradas e saídas. Por isso, a presença num
espaço público é anônima, e os que nele se encontram são estranhos uns
aos outros, assim como são desconhecidos para os empregados da
manutenção. Os espaços públicos são os lugares nos quais os estrangeiros
se encontram. De certa forma eles condensam - e, por assim dizer,
encerram - traços distintivos da vida urbana. É nos locais públicos que a
vida urbana e tudo aquilo que a distingue das outras formas de
convivência humana atingem sua mais completa expressão, com alegrias,
dores, esperanças e pressentimentos que lhe são característicos. (2009,
p.69-70)

Os espaços públicos podem ser estatais ou não estatais. São estatais na medida em que criados pelo Estado atendendo a toda população. Os espaços públicos não estatais são aqueles voltados ao público, mas que não são estatais (ex.: shoppings centers).

Afirma Batista (2006, p. 342 e seguintes) que "em meio à crise institucional, surgem os movimentos sociais e as organizações não governamentais, defendendo interesses relevantes que não são plenamente satisfeitos pela simples atuação do Estado". Continua o Autor aduzindo que esse movimento resulta no surgimento de organizações e movimentos que auxiliam no exercício das funções públicas, mas que não se trata de substituição da atuação do Estado nas atividades publicas essenciais, como saúde, 
segurança, educação, ou seja, de uma privatização disfarçada. Assim, os espaços públicos não estatais asseguram a participação popular na gestão pública.

Fischer (1994) afirma que os espaços de transição entre o público e o provado não é nem completamente privado, nem totalmente público, correspondendo assim aos espaços onde pessoas com afinidades em comum se relacionam.

O espaço público não estatal serve à democracia participativa ou direta, acrescendo à participação cidadã nos assuntos públicos. Como afirmam Pereira e Grau (1999, p. 1011):

A proteção do direito à coisa pública, de fato, requer recriar o espaço público como o espaço que faz possível a conexão do principio da igualdade política com o da participação dos cidadãos no que é de interesse comum, qualquer que seja o âmbito em que ele esteja situado. No entanto é preciso destacar que este processo não está isento de dificuldades. Pelo contrário, seu desdobramento acarreta uma serie de dilemas e desafios.

A existência de espaços públicos não comandados por uma ideologia dominante, onde o debate possa ser aberto, amplo e não direcionado por essa ideologia, é fundamental na construção de condições dignas de trabalho e na viabilização de instrumentos que garantam essas condições.

Bauman (2009) alimenta a discussão acerca dos valores instituídos na contemporaneidade, e essa percepção pode ser encampada pelo mundo do trabalho. $\mathrm{O}$ Autor afirma que a solidariedade é substituída pela competição, e os indivíduos se sentem abandonados, entregues à própria sorte, como se a gestão de suas vidas fosse uma construção individual que não dependesse em nenhum grau da vida social. Essas pessoas ficam reféns de seus próprios recursos, que via de regra são escassos e claramente inadequados.

O Sociólogo continua, aludindo que "a corrosão e a dissolução de laços comunitários nos transformaram, sem pedir nossa aprovação, em indivíduos de jure (de direito); mas circunstâncias opressivas e persistentes dificultam que alcancemos o status implícito de indivíduos de fato ${ }^{87, \%}$. (BAUMAN, 2009, p.21)

\footnotetext{
87 O autor acaba sublinhando uma distinção muito sensível no universo dos Direitos Humanos, que é a da igualdade material e a da igualdade formal. A igualdade formal aparece na Revolução Francesa de 1789, com a máxima "todos são iguais perante a lei". Ressalte-se que, no entanto, "todos" eram apenas os homens livres, ou seja, excluía-se dessa pretensa igualdade, por exemplo, as mulheres. O que significa dizer, em última instância, que qualquer diferença entre os cidadãos era desconsiderada, ainda que, na prática, essas diferenças contribuíssem para desvirtuar a concepção de igualdade genérica perante a lei. Em oposição a esse
} 
E é na busca de se atingir a melhor condição de igualdade material que este sistema possa permitir que os trabalhadores devem utilizar os espaços públicos para a participação popular.

Uma breve distinção entre a cultura de massa e a cultura popular se faz necessária para o aprofundamento dessa idéia de espaços públicos que não sejam dominados por uma ideologia.

A cultura popular é aquela que surge da vivência de um povo, que cria sua própria forma de ver o mundo, de acordo com as experiências de vida, históricas, que passa, idéias e pensamentos que o refletem, produzindo com particularidade sua própria arte, princípios, tradições, hábitos, crenças, conhecimento e costumes.

A cultura de massa pressupõe um desvirtuamento da cultura popular, impingida por um poder hegemônico de acordo com suas próprias necessidades, que transforma, modifica, molda à sua vontade a cultura popular, retirando inclusive a possibilidade crítica que traz a cultura popular. A cultura se torna, nesse último contexto, mais um produto de consumo, achatado, padronizado, que exclui ou mitiga as diferenças, e o que resta é a reprodução cada vez mais empobrecida da cultura globalizada imprimida pelo neoliberalismo.

Neste contexto, imaginar que um espaço, ainda que público, mas dominado por um setor ideológico contrário ao desenvolvimento social, possa fomentar a participação popular do trabalhador e da comunidade para a melhoria das condições de trabalho, é ilusão. Exemplo solar disso é a atuação da mídia quando informa a respeito de greve de trabalhadores.

O espaço de comunicação, ainda que a Constituição Federal preveja em seu texto estar vedada a proibição de censura ideológica (art. 220,§ $2^{\circ}$ ), certamente atende às necessidades de quem detém o poder. Apesar de serem instrumentos públicos, são, através de concessão, cedidos a particulares, que obviamente colocarão o veículo a serviço de seus interesses, sem praticamente qualquer limite ético.

Essa encampação do público pelo privado culmina no fato de que a mídia, que teria precipuamente a função de informar o cidadão, e não de construir consumidores, no Brasil

conceito, e mais em consonância com a terceira vertente, tão ignorada, mas nem por isso menos importante, da revolução francesa - a fraternidade - surge o conceito de igualdade material, que, ao contrário da igualdade formal, busca considerar as desigualdades entre os indivíduos, o que justificaria um tratamento desigual entre indivíduos desiguais, para que se possa, dessa maneira, garantir que, na prática, tais pessoas sejam igualadas. A concepção de igualdade material justifica inclusive as políticas públicas de inclusão através de ações afirmativas. 
e em boa parte do planeta, acaba perseguindo muito mais este segundo ideal na busca desmedida pelo lucro.

Assim, se a mídia deveria ser um espaço público de discussão, na realidade se afasta bastante deste papel e se coloca a serviço do grande capital, como apontam Pereira e Grau:

Primeiro, porque ao sustentar-se a participação cidadã na representação através de organizações de interesses, privilegia aqueles interesses que dispõem de recursos de poder - entre outros, o organizativo. Segundo, porque exclui da discussão a possibilidade de apelar à um interesse público como tal. (1999, p. 11)

Como já aludido, o modo como os meios de comunicação divulgam e atribuem valores (negativos) aos Direitos Sociais (trabalho, seguridade, etc.) provoca o desvirtuamento de direitos alcançados com muita luta social. Tal fato é conhecido e muito debatido nos meios acadêmicos ${ }^{88}$.

A greve, exemplo que ilustra esta percepção, quando exposta na mídia, se transforma: de direito garantido constitucionalmente em um movimento fadado à pecha de baderna, que atrapalha a vida da população.

Ora, a greve é uma das formas mais utilizadas e historicamente consolidadas de movimento social, como restou claro de uma das últimas greves que mais atenção popular obteve, conhecida como a greve da EMBRAER.

Em meados de 2008, por conta da crise econômica mundial derivada da crise imobiliária norte-americana, a empresa EMBRAER (Empresa Brasileira de Aeronáutica) entendeu pela necessidade de dispensar aproximadamente $20 \%$ de sua força de trabalho, o que acarretou a rescisão de contrato de 4.400 empregados. Esta dispensa coletiva, cujos efeitos seriam sentidos não apenas pelos trabalhadores dispensados e suas famílias, mas por toda comunidade na qual eles estão inseridos, gerou um movimento grevista que atingiu não apenas os empregados da EMBRAER, mas empregados de outras empresas que aderiram a greve por solidariedade, além de outros setores sociais como os professores universitários, que reconhecendo a importância da manifestação, aderiram também por solidariedade ao movimento.

${ }^{88}$ Vide José Arbex Jr., Dennis de Oliveira, entre outros. 
A força dessa mobilização, ou seja, pelo exercício da participação popular e da repercussão que ela causou, dentre outros fatores, culminou na liminar judicial ${ }^{89}$ que suspendeu as rescisões realizadas, adotando uma interpretação que, pela inteligência da fundamentação desta decisão, atribui eficácia aos ditames de dignidade do trabalhador, como de depreende do trecho abaixo colacionado:

Como é cediço, em observância aos princípios constitucionais da livre iniciativa e concorrência (artigos $1^{\circ}$, inciso IV, e 170, inciso IV, CF), detém o empregador os poderes de dirigir, regulamentar, fiscalizar e disciplinar a prestação de serviços dos seus empregados. (...) Nesse contexto, e tendo em vista a própria proteção constitucional à propriedade (art. $5^{\circ}$, inciso XXII, CF), possui o empregador a liberdade de contratar e dispensar empregados, desde que a dispensa seja realizada por meio de critérios objetivos e com respeito aos direitos da personalidade humana. No entanto, o poder diretivo do empregador, consubstanciado na possibilidade de rescindir unilateralmente os contratos de trabalho dos empregados, não é absoluto, encontrando limites nos direitos fundamentais da dignidade da pessoa humana (g.n.). Como é cediço, a Constituição Federal de 1988 elencou a dignidade do ser humano como princípio fundamental da República Federativa do Brasil (art. $1^{\circ}$ ). Esse princípio se traduz na necessidade de respeito aos direitos fundamentais da pessoa como integrante da sociedade. A par disso, é bem verdade, o princípio da ordem econômica e livre concorrência, mas desde que fundada na valorização do trabalho humano, assegurando a todos uma existência digna e conforme os ditames da justiça social, priorizando os valores sociais do trabalho sobre os valores da sociedade capitalista (g.n.) (art. 170). (...) Concebido como referência constitucional unificadora de todos os direitos fundamentais [observam Gomes Canotilho e Vital Moreira], o conceito de dignidade da pessoa humana obriga a uma densificação valorativa que tenha em conta o seu amplo sentido normativo-constitucional e não uma qualquer idéia apriorística do homem, não podendo reduzir-se o sentido da dignidade humana à defesa dos direitos pessoais tradicionais, esquecendo-a nos casos de direitos sociais, ou invocá-la para construir 'teoria do núcleo da personalidade' individual, ignorando-a quando se trate de garantir as bases da existência humana. Daí decorre que a ordem econômica há de ter por fim assegurar a todos existência digna (art. 170), a ordem social visará a realização da justiça social (art. 193), a educação, o desenvolvimento da pessoa e seu preparo para o exercício da cidadania (art. 205) etc, não como meros enunciados formais, mas como indicadores do conteúdo normativo eficaz da dignidade da pessoa humana. (g.n.) É nesse sentido que já se reconheceu, há muito, que a proteção à integridade da pessoa humana estende-se - como não poderia deixar de ser - ao trabalhador, destinatário de maior interesse público, não só por seu status de agente transformador da realidade sócio-econômica, mas também pela posição jurídica que ocupa nas relações de tomada e prestação de serviços. Tal assertiva deve ser interpretada não apenas em face dos direitos individuais do empregado, mas também em relação aos direitos transpessoais - coletivos

${ }^{89}$ PROC. TRT/15 ${ }^{\text {a }}$ REGIÃO No 00309-2009-000-15-00-4 
ou difusos - inerentes à categoria operária, pois, reitere-se, há indiscutível interesse público na preservação da dignidade do trabalhador enquanto pessoa humana, fundamento do Estado Democrático Brasileiro. (Processo TRT/15 $5^{\mathrm{a}}$ REGIÃO No 00309-2009-000-15-00-4)

Apesar de não ter atingido integralmente seus objetivos, já que a liminar foi afastada, certamente a valorosa decisão serve de precedente para embates similares, além de que sua fundamentação orienta para o sentido do valor do trabalho, e dos parâmetros de interpretação que levam ao trabalho decente.

O caso EMBRAER demonstra a força da participação popular nas questões que vão além do âmbito privado, como no caso do trabalho, que é de interesse público. Diante das transformações mundial nessa etapa de mundialização da política neoliberal, muitos Estados procuram conceder vantagens para atrair capital, não apenas sucateando a proteção social de seus internos (desregulamentação, reformas previdenciárias e fiscais), mas também exigindo dos trabalhadores mais do que a razão e a lógica permitem, como mostra o caso da empresa Foxconn ${ }^{90}$, que fabrica peças para empresas como Apple (peças para Iphone), que exige dos empregados um tempo de trabalhado desarrazoado diante da humanidade dessas pessoas, ou seja, uma jornada de trabalho que se não esgota pelo cansaço físico, esgota pelo cansaço mental.

A identificação e a discussão acerca do que prejudica o trabalhador, expõe sua vida, o relega à condição degradante, com a participação ativa deste ator social, deve compor claramente qualquer tentativa de construção de um conceito de trabalho decente mais efetivo.

Esta participação popular nos grandes debates públicos é elemento basilar da democracia participativa.

Destarte, se faz necessário maior explanação acerca dos dois institutos, quais sejam, democracia participativa e espaço público.

Como salienta Solange Gonçalves Dias, a democracia é um valor já consolidado e consagrado, ainda que traga frustrações porque ela "não tem produzido benefícios sociais suficientes, e, depois, porque tem falhado na tarefa de formar cidadãos conscientes dos méritos próprios da democracia”. Continua a Autora referindo que isso não significa que a democracia esteja ameaçada, haja vista estar este valor marcado na classe dominante, mas que o da precariedade do desempenho funcional e pedagógico das instituições

\footnotetext{
${ }^{90}$ Vide Capítulo 1.
} 
democráticas, deve ser enfrentada, certamente pela via da participação popular de forma mais direta.

A democracia pode ser exercida de forma representativa ou de forma participativa.

A democracia representativa, para Gonçalves (2001, p. 9) "constitui o arcabouço moldado pelo instituto da representação política, em cujo contexto o povo, atuando somente por intermédio de seus representantes, "não tem qualquer interferência direta no jogo cotidiano da política"”. Assim, no Brasil, através do sufrágio universal, o povo escolhe seus representantes que moldarão a vida política da população, mas, como regra geral, não há participação direta da população na gestão da vida pública, daí porque se diz dessa forma que ela representa a democracia indireta ${ }^{91}$.

Sem afastar a relevância da democracia representativa, há ainda outra classificação da democracia, a chamada democracia participativa, que, nos dizeres de Solange Gonçalves Dias (2001, p. 77), pode ser conceituada como:

o regime político baseado na intervenção direta, rotineira e transparente de cidadãos individualmente considerados ou organizados em associações ou em grupos representativos de interesses, de identidades ou de valores, no planejamento, na deliberação, no exercício ou na fiscalização da atuação governamental, ou, ainda, na formação da vontade legiferante do Estado, por meio de canais formais de participação política.

Assim, aduz a Autora, é de se afirmar que a democracia participativa se fundamenta no reconhecimento "da capacidade do homem comum para intervir direta e cotidianamente na formação e na execução da vontade estatal; decorre do reconhecimento de que a disputa por interesses é inevitável e de que a democracia deve propiciar os meios para que as contendas políticas ocorram abertamente, em espaços públicos e plurais” (DIAS, 2001, p. 13-14).

Para que as reformas concretizadas pelo Estado sejam mais eficazes e apresentem resultados que solucionem problemas sociais que vêm se universalizando como a precarização do trabalho e a diminuição ou mesmo a retirada de direitos da seguridade social, é de suma relevância que haja a participação popular especialmente nos debates que antecedem as decisões tomadas pelo governo. Conforme alude Elisabete Ferrarezi (1997, p. 1-2):

91 Alguns, como José Afonso da Silva, indicam também a existência da democracia semidireta, que representa a democracia indireta pontuada com institutos de participação direta como o referendo, a iniciativa popular, o plebiscito e a ação popular. 
os desafios colocados para a superação dos problemas sociais não apenas se circunscrevem a atuação do poder estatal, uma vez que a diversidade do mundo contemporâneo coloca em cena novos atores e novas exigências sociais que vão além das possibilidades de o Estado contemplar. Não é por outro motivo que agências multilaterais, como o $\mathrm{BID}$, tem orientado seus recursos para projetos que contenham mecanismos de fortalecimento da participação comunitária e para projetos cujas próprias organizações da sociedade civil atuam na provisão direta de serviços sociais e no controle das ações públicas estatais. (...) A forte conotação ideológica de que se revestiu o "princípio de mercado" (...) com a presença de pressupostos como autonomia, liberdade, iniciativa privada, concorrência, competitividade, eficácia/eficiência, lucro - exerceu influência na tentativa de legitimar a retirada do Estado da prestação de serviços, ocultando a atuação econômica estatal em favor das empresas como incentivos fiscais, tributação regressiva, etc. (g.n.) Contudo, é importante reconhecer que o princípio de mercado trouxe o apelo ao "princípio de comunidade" e às idéias que carrega consigo: participação, solidariedade, autonomia, etc. Se, de um lado, esse apelo contribuiria para obtenção de cumplicidade da sociedade na legitimação da transferência dos serviços de provisão estatal para o setor público não lucrativo, auxiliando a materialização da necessidade do Estado "mínimo", de outro lado, esse processo também pode ser entendido pela positividade que apresenta à sociedade civil, reforçando e legitimando a participação dos novos atores na arena pública não estatal, fortalecendo sua organização na resolução de problemas sociais.

Ainda que não se defenda de nenhuma maneira a retirada do poder imperativo do Estado frente às questões que notadamente não são exatamente privadas, como as questões que envolvem as relações de trabalho, não se pode afirmar que a democracia participativa, que conforme anteriormente aludido, pode e deve se dar não só nos espaços públicos estatais, mas também nos espaços públicos não estatais e mesmo nos privados (exercendo assim a função social da propriedade) não é importante para a eficácia de um conceito de trabalho decente que se pretende, não apenas na medida em que circunscreve os aspectos da dignidade do trabalhador, mas quando estabelece elementos importantes para a interpretação jurídica e para a criação de políticas públicas de fomento ao trabalho decente.

Uma ilustração importante de como um trabalho degradante afasta o trabalhador do diálogo social se dá na verificação de como o trabalho precarizado, no caso por meio da terceirização, corrói o movimento sindical. 
O Sindicato pode certamente incorporar, através de seu aparelho, o papel de espaço público não estatal de encontro para a discussão de causas relacionadas ao labor, função precípua deste órgão.

Em um cenário de trabalho terceirizado, onde o empregado não presta seus serviços ao empregador, mas a um tomador de serviços, o papel que o local da empresa pode exercer como ponto de convivência de trabalhadores se dissipa. Via de regra, os trabalhadores que se encontram nas mesmas condições de trabalho, convivendo, discutem e estabelecem medidas na defesa de seus direitos para a melhoria de sua condição, fortalecendo-se no coletivo, e, assim, possibilitando que o movimento social surja e se desenvolva.

Na medida em que não se encontram, ou, que o encontro reúna apenas poucos trabalhadores, como se dá no caso de prestação de serviços para um tomador, a possibilidade de criação de um movimento coletivo se dissipa, especialmente pela falta de um espaço de encontro em comum, onde ao menos a maioria dos trabalhadores possa conviver e assim debater as questões do cotidiano de trabalho que lhes são caras.

Com trabalhadores pulverizados, a partilha das dificuldades encontradas naquelas relações de emprego não acontece, e assim resta completamente enfraquecido o movimento sindical deste setor. Esse enfraquecimento pode se dar por diversos fatores, como a burocratização do movimento sindical, o descrédito que tal instituição vem sofrendo ao longo dos anos, etc., mas não se pode afastar o fato de que a falta de um espaço de convivência é um fator determinante para esse resultado.

Para que o movimento sindical se fortaleça, é necessário que os indivíduos se reconheçam como partícipes dos mesmos problemas, e que encontrem no coletivo a resposta para a vindicação de suas questões, sem o que o sindicato voltado aos terceirizados perde muito em força. Não é outra a idéia a seguir exposta:

A terceirização se apresenta não só como uma forma de precarização das condições dos trabalhadores, é também a precarização das relações entre os mesmos na medida em que estabelece segmentação e dificulta a sua mobilização, agravando a crise do sindicalismo.

Desde o seu surgimento e emancipação, o movimento sindical atualmente vive uma crise ampla que, concordando com Everaldo Augusto, tem natureza política, ideológica e organizativa. A identidade sindical é a base sólida de um sindicato forte e atuante e é sobre ela que incide a estratégia ideológica da terceirização. (AMORIM, 2007, p. 21) 
Nesse sentido, importa salientar que os sindicatos e demais entidades "têm buscado oferecer alternativas; no entanto, os esforços dessas instituições não têm acompanhado a mesma velocidade do processo de precarização e desregulamentação dos direitos dos trabalhadores". (NASCIMENTO, 2008, p. 1093)

Assim, a democratização participativa deve ser internalizada no ambiente corporativo, seja por meio do fortalecimento do movimento sindical, seja por meio de movimentação dos trabalhadores (empregados ou não) das empresas, sendo certo que uma forma não exclui a outra; ao contrário, na medida em que os trabalhadores se unam nos ambientes de trabalho, criam os embriões de fortalecimento de um movimento que se possa dizer sindical.

O exemplo acima selecionado demonstra a importância, portanto, dos espaços públicos e da democracia participativa para a promoção e efetivação do trabalho decente.

\subsubsection{A eficácia do trabalho decente por meio da aplicação dos princípios basilares do Direito do Trabalho}

Antes de adentrar na interpretação específica que se pretende atribuir para as questões que envolvem a dignidade do trabalhador, impõe-se a apresentação de um panorama sobre a hermenêutica jurídica e sua necessidade para a eficácia do conceito de trabalho decente.

Alude Carlos Maximiliano (1996) que a hermenêutica descobre e fixa os princípios que regem a interpretação, é a teoria científica da arte de interpretar e a interpretar é uma expressão de direito que não é simplesmente tornar claro o respectivo dizer, abstratamente falando, é, sobretudo, revelar o sentido apropriado para a vida real, e conducente à uma decisão reta. Não se trata, segundo o Autor, de uma arte para simples deleite intelectual, para o gozo das pesquisas e o passatempo de analisar, comparar e explicar os textos; assume, antes, as proporções de uma disciplina eminentemente prática, útil na atividade diária, auxiliar e guia dos realizadores esclarecidos, preocupados em promover o progresso, dentro da ordem, bem como dos que ventilam nos pretórios os casos controvertidos, e dos que decidem os litígios e restabelecem o Direito postergado.

Pode toda regra jurídica ser considerada como uma proposição que subordina a certos elementos de fato uma consequência necessária, incumbindo ao intérprete descobrir 
e aproximar da vida concreta, não só as condições implícitas no texto, como também a solução que este liga às mesmas. Assim, continua o Autor, a aplicação da interpretação consiste em enquadrar um caso concreto na norma jurídica adequada. Submete às prescrições da lei uma relação da vida real, procura e indica o dispositivo adaptável a um fato determinado. Em outras palavras, tem por objeto descobrir o modo e os meios de amparar juridicamente um interesse humano; o direito, destarte 'precisa transformar-se em realidade eficiente, no interesse coletivo e também no individual. A aplicação pressupõe a hermenêutica, como a medicação a diagnose'.

Maximiliano afirma que o intuito de imprimir efetividade jurídica às aspirações, tendências e necessidades da vida constitui um caminho mais seguro para atingir a interpretação correta do que o tradicional apego às palavras, 'o sistema silogístico da exegese'. Se é certo que o juiz deve buscar o verdadeiro sentido e alcance do texto; todavia este alcance e aquele sentido não podem estar em desacordo com o fim colimado pela legislação - o bem social.

Para Pedro Vidal Neto (1985), hermenêutica "é a sistematização das regras para a interpretação do direito"; e a interpretação é a "atividade central que se desenvolve na aplicação do direito. É seguramente a mais importante e árdua tarefa do jurista”. O Autor afirma que

a interpretação do contrato de trabalho não pode deixar de ser condicionada pelo significado global do modelo, obviamente orientado para a proteção do empregado e, portanto, deve ser regida pelos mesmos critérios adequados à interpretação das leis trabalhistas. É nesse terreno que afinal encontram eficácia os princípios de Direito do Trabalho, inclusive o in dubio pro operario.

Nesta perspectiva, é ressaltada a importância que os princípios têm na estruturação do Direito do Trabalho como ramo autônomo, e o afastamento da função interpretativa desses princípios culminaria na utilização de uma lógica privatística, que não se adapta às relações de trabalho, porque estas tratam de relacionamentos entre partes desiguais, ou seja, em não havendo a interferência Estatal na contenção da autonomia da vontade do empregador, que notoriamente é a parte mais forte da relação, esta está fadada à servir de instrumento de uma exploração desmedida e espoliante frente ao trabalhador

Suzete Carvalho (1994) informa que o juslaboralista tem árdua tarefa no que toca à interpretação das normas trabalhistas, "na medida em que este direito está ligado à própria 
questão da sobrevivência da maior parte da população, constituídas pelos milhões de trabalhadores e suas famílias". Continua aduzindo que " aos aplicadores cabe ter consciência de seu papel, desvestindo-se das máscaras ideológicas que encobrem seus olhos, desvendando-se a realidade concreta e atual e levando em consideração a experiência histórica, único salvo-conduto para um futuro menos injusto".

Não é incomum que se atribua à interpretação conotação de desvirtuamento da ordem jurídica, em relação à segurança jurídica, tendo em vista que o exercício da exegese possibilita aos juristas uma atuação com subjetividade. No entanto, não se concretiza tal acusação, porque nosso ordenamento jurídico atribui ao juiz poder discricionário (e não arbitrário), e exige fundamentação em todas as sentenças, o duplo grau de jurisdição, com constituição colegiada em todos os tribunais, é mais uma garantia de que não haverá julgamento arbitrário.

Também importa trazer à baila definições e outros aspectos gerais dos princípios, para que possa o trabalho convergir adequadamente à interpretação do Direito do Trabalho a partir de seus princípios fundantes.

Princípios, como ensina Fábio Konder Comparato (2003), são normas que nos obrigam a agir, em função do valor objetivo do bem visado pela nossa ação, ou do objetivo final que dá sentido à vida humana, e não de um interesse puramente subjetivo, que não compartilhamos com a comunidade. Esse valor objetivo nada mais é que o bem da pessoa humana, considerada em todas as suas dimensões: como indivíduo, grupo ou classe social, povo ou a própria humanidade.

Alexy entende a norma jurídica não apenas atrelado aos fatos e suas consequências jurídicas, institutos que se aplicam muitos mais às regras do que propriamente aos princípios. Como estende sua concepção de normas aos princípios (normas podem ser regras ou princípios), encontrou uma definição que melhor compusesse esses dois elementos. Assim, para o Autor, norma é um enunciado de obrigação, permissão e proibição $^{92}$ (operadores deônticos); tanto a regra quanto o princípio se enquadram nessa definição, podendo portanto compor o conceito de norma. As regras seriam os mandamentos definitivos, porque emitem uma ordem previamente estipulada, e os princípios são mandamentos de otimização, na medida em que têm a aplicação definida pelo julgador diante do caso concreto a ele apresentado, sendo portando sopesado diante da casuística:

${ }^{92}$ Cf. o conceito semântico de norma em Alexy (2008, p. 53) 
(...) tem-se princípios como mandamentos de otimização que são caracterizados por poderem ser satisfeitos em graus variados e pelo fato de que a medida de sua satisfação não depende somente das possibilidades fáticas, mas também jurídicas. (2008, p. 90)

Um dos limites à aplicação de um determinado princípio diante do caso concreto se dá diante do conflito entre princípios, ou seja, quando um princípio acaba por invadir a aplicação de outro princípio ainda mais importante, por isso Alexy afirma que, ao aplicar-se um princípio, deve-se equilibrar essa efetivação sopesando-a diante da existência de outros normas princípios, caso contrário seria impossível definir a medida de sua aplicação.

Diante da distinção concreta entre normas e princípios, pode-se afirmar que sua aplicação também se dá de forma diferente. As regras são aplicadas por subsunção, ou seja, mediante o conector entre condição de fato e sua consequência jurídica. Estabelecido um tipo (uma ação, uma conduta) na lei, a essa ação corresponde uma consequência jurídica. Já em relação aos princípios, não há uma consequência previamente estabelecida, sequer uma ação determinada previamente estabelecida, por isso devem ser aplicados por ponderação, ou seja, verificando o caso concreto, identifica-se o princípio a ser aplicado e procede-se ao sopesamento deste princípio em relação ao conjunto de princípios incidentes.

Desta forma, no caso de conflito entre princípios, o exercício da ponderação indicará qual dos princípios deverá prevalecer naquele caso concreto.

Para Alexy, aí reside uma das diferenças entre regras e princípios. No caso de conflito de regras, por serem normas pré-definidas, o problema pode ser resolvido de duas formas: cria-se uma regra de exceção, ou seja, extraordinária, ou uma das regras acaba excluída do sistema jurídico. No caso de conflito entre princípios, ainda que um prevaleça diante do caso concreto, o outro não é excluído do sistema.

O Autor esclarece, no entanto, que a ponderação deve seguir um procedimento específico, sendo que esta regra de proporcionalidade deve se pautar por três elementos, a saber: adequação, necessidade e proporcionalidade.

Adequação se estabelece quando a solução para o conflito entre princípios no caso concreto concretiza um dos princípios envolvidos, ou seja, é a medida adequada para atingir a finalidade da norma. Necessidade se dá na medida em que o conflito é solucionado a partir do meio menos gravoso, ocasionando o menor impacto possível em 
relação aos outros princípios. Proporcionalidade, aqui expressada no seu sentido mais específico, ocorre na medida em que se opta pelo princípio que, dentro daquele caso concreto, tem mais relevância, mais peso, diante dos outros princípios que estão com este colidindo.

Para que um princípio no caso concreto prepondere sobre outro, Alexy indica que seja aplicada a regra da precedência condicionada. Isso porque a precedência entre os princípios só se estabelece diante do caso concreto, porque não têm relação absoluta de precedência:

A solução para essa colisão consiste no estabelecimento de uma relação de precedência condicionada entre os princípios, com base nas circunstâncias do caso concreto. Levando-se em consideração o caso concreto, o estabelecimento de relações de precedências condicionadas consiste na fixação de condições sob as quais um princípio tem precedência em face de outro. Sob outras condições, é possível que a precedência seja resolvida de forma contrária. (p. 96)

É de se revelar ainda a importância que a lei do sopesamento tem diante da otimização em relação aos princípios colidentes, li esta que pode ser dividida em três passos, a saber: a) avaliação do grau de não satisfação ou afetação de um dos princípios, para que se defina a intensidade da intervenção de um dos princípios; b) avaliação da importância da satisfação do princípio colidente diante daquele caso concreto e c) avaliação se a importância da satisfação do princípio colidente justifica a afetação ou a não-satisfação do outro princípio.

Dworkin (2007) participa da idéia de que os princípios têm obrigatoriedade, como se pode depreender do seu Levando os direitos a sério:

Podemos tratar os princípios jurídicos da mesma maneira que tratamos as regras jurídicas e dizer que alguns princípios possuem obrigatoriedade de lei e devem ser levados em conta por juízes e juristas que tomam decisões sobre obrigações jurídicas. Se seguirmos essa orientação, deveremos dizer que nos Estados Unidos 'o direito' inclui, pelo menos, tanto princípios como regras (p. 46-47)

O Autor continua explanando acerca dos princípios, e é interessante perceber que os alça à categoria de algo que deva ser exigido, por isso deve ser observado na aplicação do direito: 
Denomino 'princípio' um padrão que deve ser observado, não porque vá promover ou assegurar uma situação econômica, política ou social considerada desejável, mas porque é uma exigência de justiça ou eqüidade ou alguma outra dimensão da moralidade. (DWORKIN, 2007, p. 46-47)

Dworkin distingue princípios de políticas. Se princípio é um padrão a ser observado, exigível em prol da justiça, pode-se dizer que política é aquele tipo de padrão que estabelece um objetivo a ser alcançado, em geral uma melhoria em algum aspecto econômico, político ou social da comunidade. Destarte, como afirma Streck (2008), a combinação de princípios jurídicos com objetivos a serem alcançados (política) oferece aos intérpretes diversas possibilidades de argumentos coerentes com o direito positivado. Pode-se, assim, concluir, que esse direito positivado, bem como os pactos estabelecidos pela autonomia da vontade privada e as decisões do Poder Judiciário devem respeitar não apenas os princípios já por ele consagrados, como o princípio da legalidade, mas os outros princípios que não são positivados, mas são parte integrante do ordenamento jurídico.

Neste sentido de integração entre regra e princípio é que se depreende o julgado abaixo colacionado:

CONCILIAÇÃO PREVIA. ARBITRAGEM. RENÚNCIA DE DIREITOS. ATO NULO. O procedimento de arbitragem adotado pela Comissão de Conciliação Prévia Intersindical, que consigna a quitação geral e irrestrita do extinto contrato de trabalho, bem como impede o ingresso de ação na Justiça do Trabalho ante o simples pagamento das verbas rescisórias, configura repugnante e fraudulenta manobra que impõe ao trabalhador a inaceitável renúncia de direitos. A irregularidade do ato praticado pela reclamada, em conluio com a Comissão de Conciliação Prévia, configura violação aos artigos 477 da CLT e $5^{\circ}$, inciso XXXV da Constituição Federal de 1988, além de colidir com o princípio protetor que norteia o Direito do Trabalho. A medida que objetiva fraudar direitos não tem acolhida no ordenamento jurídico, em face da aplicação do art. $9^{\circ}$ da CLT, segundo o qual são nulos os atos praticados com o objetivo de desvirtuar, impedir ou fraudar a aplicação dos preceitos contidos na Consolidação das Leis do Trabalho. (TRT $2^{\mathrm{a}}$ região, $4^{\mathrm{a}}$ T., p. 02766-2003-052-02-00-8)

É de se salientar, ainda, que os princípios têm funções específicas, na medida em que são fundamentais para a compreensão apropriada da norma, a fim de se compor um sistema normativo integrado; e aí reside a importância de se determinar suas funções, que 
podem ser qualificadas em função informadora, já que os princípios devem orientar as ações dos três poderes estatais e dos cidadãos em geral - destaque-se aí a importância dessa função na criação de leis trabalhistas e na instituição de políticas públicas; função normativa, já que compõem a norma no caso de lacuna ou omissão da lei e função interpretativa, estabelecendo que os princípios são parâmetros de interpretação da norma, ressaltando-se a importância desta função no que tange às decisões do Poder Judiciário.

Esclarecido o sentido atribuído aos princípios, a proposta que ora se faz é de que a eficácia do trabalho decente tem como passo determinante a interpretação das normas sob a ótica dos princípios basilares do Direito do Trabalho.

Os princípios basilares do Direito do Trabalho são todos derivados do princípio protetor, já definido acima, de acordo com o entendimento de Godinho Delgado. Para Plá Rodrigues, os princípios de Direito do Trabalho são classificados da seguinte maneira: 1) princípio da proteção; 2) princípio da irrenunciabilidade dos direitos; 3) princípio da continuidade da relação de emprego; 4) princípio da primazia da realidade; 5) princípio da razoabilidade; 6) princípio da boa-fé e, por fim, 7) princípio de não discriminação.

Plá Rodrigues, diferentemente de outros autores que os alocam como princípios, estabelece três regras pelas quais se concretizam o princípio protetor, que são a regra da aplicação da norma mais favorável, do in dubio pro operario e da condição mais benéfica.

Considerar-se-á no presente trabalho, no entanto, tais regras como princípios que compõem a fundamentação do Direito do Trabalho como ramo autônomo. Além disso, o princípio da boa-fé e da razoabilidade são princípios gerais de direito, motivo pelo qual não serão elencados no rol de Princípio Trabalhistas; no entanto, serão incluídos outros princípios que legitimam o Direito do Trabalho como ramo autônomo. Partindo da idéia de que o princípio protetor é a fonte de onde advêm os outros princípios, resta estabelecer suas identificações.

O princípio do in dubio pro operario, diz respeito a norma a ser aplicada ao trabalhador, que deverá ser a mais favorável em caso de mais de uma possibilidade de interpretação da norma, a não ser quando se tratar de prova ou em casos de manifesta vontade do legislador, não dependendo neste caso da exegese para que se entenda o teor da lei.

Segue abaixo julgados que manifestam a dignidade do trabalhador com fundamento no aludido princípio: 
Cooperativa. Inexistência de verdadeira "affectio societatis". Intermediação de Mão-de-Obra. Reconhecimento de Vínculo Empregatício com as tomadoras. 1- Segundo o conceito contido na Lei 5.764/71 "celebram contrato de sociedade cooperativa as pessoas que reciprocamente se obrigam a contribuir com bens ou serviços para o exercício de uma atividade econômica, de proveito comum, sem objetivo de lucro" ( $\operatorname{art.} 3^{\circ}$ ). No caso em questão, não se vislumbra o preenchimento desse requisito. Em sociedade do tipo noticiado nos autos, cujo escopo se restringe ao recrutamento e inserção de trabalhadores especializados junto às tomadoras, não emerge clara a denominada "affectio societatis", requisito indispensável para que se afaste a subordinação jurídica que caracteriza o contrato de trabalho. 2 - Ainda que se pudesse admitir, para argumentar, que o empregado tivesse aderido espontaneamente ao trabalho cooperativo, constatada a presença de subordinação jurídica em relação a qualquer das contratantes, evidenciar-se-ia a existência de liame de emprego, uma vez que para o direito do trabalho, não basta a livre manifestação de vontade do empregado, para que deixe de se constituir eventual obrigação. Não se pode olvidar que as normas que regem a matéria são, em sua grande maioria, de ordem pública e dispõem sobre direitos irrenunciáveis, além do que esse ramo do direito é fundado em princípios universais ( v.g. princípio da norma mais favorável, "in dubio pro operario", etc ), cujo alcance se destina à proteção da própria dignidade do trabalhador ( arts. $1^{\circ}$, III e IV, $7^{\circ}$, I a XXXV, CF). (TRT $2^{\text {a }}$ Região, $10^{\text {a }}$ T., p. 02622-2002001-02-00-8)

Lide trabalhista. "In dubio, pro operario". O empregador que não cumpre as leis não pode ter o benefício da dúvida nas lides trabalhistas. A solução há de pender em favor do trabalhador, que é o beneficiário da lei descumprida. Assim deve ser interpretada a CLT em seu conjunto. (TRT 2a Região, 9a T., p. 19990623409)

O princípio da aplicação da norma mais favorável ao trabalhador, diz respeito à hierarquia das normas trabalhistas, ou seja, diante da pluralidade de normas, identifica qual norma é a hierarquicamente superior no caso concreto. A guisa de exemplo, podemos 
identificar a questão do adicional de horas extras. De forma geral, a norma constitucional, seguindo a pirâmide Kelseniana, é a mais hierarquizada. No entanto, no Direito do Trabalho, ainda que a norma constitucional jamais seja inobservada, é possível que outra ocupe o cume da pirâmide, como no caso de uma norma coletiva que estabeleça um percentual superior ao indicado na Constituição. Assim, se uma Convenção Coletiva estabelece que para aquela determinada categoria o percentual de adicional de horas extras é de $70 \%$, essa norma é hierarquicamente superior à norma constitucional que estabelece um índice mínimo de 50\%.

O princípio da aplicação da condição mais benéfica, diz respeito ao direito adquirido previsto no artigo $5^{\circ}$, inciso XXXVI, da $\mathrm{CF} / 88$, onde se vê que a lei não prejudicará o direito adquirido, o ato jurídico perfeito e a coisa julgada.

O princípio da primazia da realidade (contrato-realidade) diz respeito à forma do contrato de emprego, que deve traduzir a exata realidade que se concretiza diuturnamente naquela relação de emprego sob pena de ser desconsiderada. Assim, a forma do contrato de trabalho, via de regra ${ }^{93}$,não importa para que se reconheça um vínculo de emprego. Por exemplo, se uma empresa contrata um trabalhador, obrigando-o a constituir uma pessoa jurídica, a fim de afastar o vínculo empregatício, tal contrato poderá ser desconsiderado em favor do contrato de emprego, se de fato naquela relação estiverem estabelecidos todos os elementos que caracterizam esse tipo de labor, como disposto no artigo $3^{\circ}$ da CLT.

Segue abaixo exemplo de decisão judicial que, com base em princípios norteadores do Direito do Trabalho, em especial os princípios da primazia e da irrenunciabilidade, efetiva o conceito de trabalho decente:

PLANO DE CARGOS E SALÁRIOS - CARGO DE CONFIANÇA BANCÁRIO - OPÇÃO DO EMPREGADO POR JORNADA DE OITO HORAS - CONTRARIEDADE AOS PRINCÍPIOS DA IRRENUNCIABILIDADE E DA PRIMAZIA DA REALIDADE ARTIGOS $9^{\circ}$ E 444 DA CLT. 1. A discussão dos autos cinge-se à validade da opção do Reclamante pelo cargo em comissão com jornada de oito horas, em confronto com o que dispõe o art. 224 da CLT. 2. As peculiaridades da consolidação e institucionalização do direito do trabalho, no contexto do Estado Social, refletiram na formação de seus princípios basilares, como os da proteção do trabalhador, da irrenunciabilidade dos direitos trabalhistas e da primazia da realidade. 3. O princípio da irrenunciabilidade decorre do próprio caráter cogente e de ordem pública do direito do trabalho. Significa, nessa esteira, que o trabalhador inclusive pela desigualdade econômica em que se encontra

\footnotetext{
${ }^{93}$ Via de regra porque existem exceções previstas na lei, onde, para determinado tipo de trabalho, é exigida forma específica, como nos contratos de experiência, que devem ser expressos.
} 
perante o empregador não pode abrir mão dos direitos legalmente previstos. Esse princípio tem por fim protegê-lo não apenas perante o empregador, mas também com relação a si mesmo. Ou seja, o trabalhador não pode se despojar, ainda que por livre vontade, dos direitos que a lei lhe assegura. 4. Por sua vez, o princípio da primazia da realidade orienta no sentido de que deve ser privilegiada a prática efetiva, a par do que eventualmente tenha sido estipulado em termos formais entre as partes. Aliás, é justamente esse princípio ao lado do princípio protetor - que matiza a aplicação do princípio da boa-fé às relações trabalhistas. 5. Não se trata, nesse último caso, de conflito entre princípios. Ao revés, necessário é, como propõe Ronald Dworkin, buscar a decisão correta para o caso concreto, a partir da conformação que os princípios abraçados pelo ordenamento jurídico devem adquirir. 6. Nesse sentido, dois parâmetros são importantes. O primeiro é afirmar a carga deontológica dos direitos, como condição necessária e indispensável para levá-los a sério . O segundo é encarar o direito a partir da premissa da integridade. 7. A premissa do direito como integridade é relevante sobretudo quando se enfrenta uma questão jurídica como a presente em uma perspectiva principiológica, o que, a seu turno, mostra-se ainda mais importante no atual paradigma do Estado Democrático de Direito. 8. No caso dos autos, a alegação de boa-fé das partes não tem o condão de conferir validade à opção efetuada pelo Reclamante. A premissa do direito como integridade impõe, com todas as suas consequiências, a aplicação dos princípios protetivo, da irrenunciabilidade e da primazia da realidade, os quais conformam e justificam, de modo coerente, o direito do trabalho em nosso ordenamento jurídico. 9. Assim, se os princípios protetivo e da primazia da realidade matizam a aplicação do princípio da boa-fé às relações trabalhistas, não há falar em boa-fé quando exatamente esses mesmos princípios são contrariados. Em outras palavras, não há, na espécie, como reconhecer boa-fé em prática que ofende os princípios protetivo e da primazia da realidade. 10. A validade da opção discutida in casu encontra óbice imediato no art. 444 da CLT, um dos corolários do princípio da irrenunciabilidade. De fato, o preceito veda a estipulação de relações contratuais de trabalho que contrariem as disposições de proteção ao labor ainda que aparentem ser favoráveis ao empregado. Nesse sentido, é importante recordar que a jornada do bancário está prevista no título III da CLT, que trata exatamente Das Normas Especiais de Tutela do Trabalho. 11. A prática narrada nos autos contraria também o art. $9^{\circ}$ da CLT, que corresponde a um desdobramento do princípio da primazia da realidade. A conduta adotada pelas partes na hipótese vertente volta-se diretamente contra a aplicação dos preceitos contidos na Consolidação das Leis do Trabalho. 12. Aliás, foi exatamente o referido princípio que ensejou, no âmbito desta Corte, a edição da Súmula $n^{\circ} 102$, I: a configuração, ou não, do exercício da função de confiança a que se refere o art. 224, $\S 2^{\circ}$, da CLT, dependente da prova das reais atribuições do empregado , é insuscetível de exame mediante recurso de revista ou de embargos. 13. Não é suficiente, assim, a declaração das partes de exercício da função de confiança; indispensável é, portanto, a correspondência da declaração de vontade à prática efetiva. 14. Entender diversamente implicaria afastar, de forma casuística, os princípios da irrenunciabilidade e da primazia da realidade, em detrimento, ainda, da coerência do próprio direito do trabalho. 15. Vale acrescentar que não é relevante à solução da controvérsia o valor eventualmente percebido pelo Reclamante, na espécie, em contrapartida à opção pelo cargo em comissão com jornada de oito horas. Tal argumento acarretaria nítido 
prejuízo à carga deontológica do direito e à normatividade dos artigos $9^{\circ}$ e 444 da CLT. 16. Assim, na hipótese vertente, a opção feita pelo Reclamante é nula de pleno direito, por contrariar os artigos $9^{\circ}$ e 444 da CLT e os princípios da irrenunciabilidade e da primazia da realidade. 17. Devido é, portanto, o pagamento, como extras, das sétima e oitava horas diárias, em face do reconhecimento do direito à jornada prevista no art. 224, caput, da CLT. Embargos conhecidos e parcialmente providos" (Número único proc: E-RR - 1040/2006-005-10-00, publicação: DJ 09/05/2008, excerto do voto. Maria Cristina Irigoyen Peduzzi - ministrarelatora. (TST, E-RR - 1040/2006-005-10-00, publicação: DJ 09/05/2008)

O princípio da irrenunciabilidade de direitos, conclamado no julgado acima, diz respeito à impossibilidade do empregado renunciar às normas de proteção, conforme artigo $9^{\circ}$ da CLT. Ora, se houvesse possibilidade de que, por meio de contrato ou outra forma, o trabalhador - hipossuficiente e, portanto, fragilizado - abrisse mão das conquistas legais que o amparam da força da autonomia da vontade do empregador, de nada valeria o estabelecimento da malha protetiva lançada pelo ordenamento jurídico. Daí porque, mesmo que o empregado se manifeste favorável à retirada de direitos, tal ato não tem validade. Este princípio é expresso no artigo 468 da CLT:

\begin{abstract}
Art. 468 - Nos contratos individuais de trabalho só é lícita a alteração das respectivas condições por mútuo consentimento, e, ainda assim, desde que não resultem, direta ou indiretamente, prejuízos ao empregado, sob pena de nulidade da cláusula infringente desta garantia.

$\S$ único - Não se considera alteração unilateral a determinação do empregador para que o respectivo empregado reverta ao cargo efetivo, anteriormente ocupado, deixando o exercício de função de confiança.
\end{abstract}

O Princípio da continuidade da relação de emprego indica que o contrato de trabalho terá validade por tempo indeterminado, porque, pela sua natureza e pelo valor que o trabalho alcança na vida das pessoas, se pode pressupor que via-de-regra ele nasce na intenção de se perpetuar, ou seja, que haverá a continuidade da relação de emprego no tempo. Os contratos por prazo determinado são inovações de flexibilização do Direito do Trabalho. Este princípio pode ser parâmetro muito interessante para a regulamentação do artigo $7^{\circ}$, I, da $\mathrm{CF}^{94}$, que mesmo após 22 anos da promulgação da $\mathrm{CF} / 88$ ainda não foi

\footnotetext{
94 Art. $7^{\circ}$ - São direitos dos trabalhadores urbanos e rurais, além de outros que visem à melhoria de sua condição social:

I - relação de emprego protegida contra despedida arbitrária ou sem justa causa, nos termos de lei complementar, que preverá indenização compensatória, dentre outros direitos
} 
adequadamente regulamentado, sendo que a dispensa imotivada do empregado, fato tão perverso na proteção do trabalhador, que diminui sua força mesmo na perspectiva coletiva, não foi ainda objeto de regulamentação por lei complementar.

Aliás, quanto a esta questão, por inércia do Legislador (motivada por poderosos interesses), continua valendo a regra de transição disposta no art. 10 da ADCT, que é a norma fundamentadora do pagamento de $40 \%$ sobre o FGTS quando da dispensa imotivada ou em caso de rescisão indireta do contrato de trabalho:

Art. 10 - Até que seja promulgada a lei complementar a que se refere o Art. 7ํㅡ, I, da Constituição:

I - fica limitada a proteção nele referida ao aumento, para quatro vezes, da porcentagem prevista no Art. 6으, caput e $\S 1^{\circ}$, da Lei no 5.107 , de 13 de setembro de 1966

O princípio da integralidade do salário se refere à impenhorabilidade do salário, conforme artigo 649, inciso IV, parágrafo $2^{\circ}$, do CPC. Exceção a tal princípio diz respeito à possibilidade de penhora no salário, quando esta advém de outro direito de cunho alimentício como no caso da pensão alimentícia.

A impenhorabilidade do salário sofre exceção, como aludido, à pensão alimentícia, mas deve também pautar a possibilidade de penhora em salário de devedor trabalhista para cumprimento de sentença na Justiça Laboral, haja vista que o salário também detém cunho alimentício, como a pensão.

Jorge Luiz Souto Maior e Manoel Carlos Toledo Filho trazem à baila esta semelhança:

Mas, a dívida trabalhista, na sua essência, principalmente, os salários e as verbas rescisórias, é de índole alimentar. Repare-se, a propósito, que o legislador deu tratamento praticamente isonômico à pensão de alimentos e à dívida trabalhista. Cabe verificar, com efeito, neste sentido, a similitude entre o rito preconizado pela Lei 5.478/68, que dispõe sobre a ação de alimentos, e o rito da CLT. A semelhança é tanta, que se poderia dizer estarmos diante de dois diplomas germanos. Assim é que, em ambos os procedimentos: a) o pedido pode ser externado verbalmente, com sua redução a termo pelo escrivão (Lei 5.478 , art. $3^{\circ}$, §s primeiro e segundo; CLT, art. $840, \S 2^{\circ}$ ); b) a segunda via da petição ou do termo será remetida ao demandado no prazo de 48 horas (Lei 5.478, art. $5^{\circ}$; CLT, art. 841); c) a citação é em regra postal (Lei 5.478 , art. $5^{\circ}, \S 2^{\circ}$; CLT, art. 841, § $1^{\circ}$ ); d) o autor é notificado da data da audiência já no ato de recebimento da petição ou da lavratura do termo (Lei 5.478, art. $5^{\circ}$, § $6^{\circ}$; CLT, art. 841, § $2^{\circ}$ ); e) na audiência, deverão estar presentes autor e réu, independentemente da presença de seus representantes (Lei 5.478, art. $6^{\circ}$; CLT, art. 843); f) a ausência do autor importará em arquivamento 
e a do réu em revelia e confissão (Lei 5.478, art. $7^{\circ}$; CLT, art. 844); g) as testemunhas, até o máximo de três para cada parte, comparecerão espontaneamente à audiência, na qual ademais serão apresentadas eventuais outras provas (Lei 5.478, art. $8^{\circ}$; CLT, arts. 821, 825 e 845); h) audiência deverá ser contínua, salvo motivo de força maior (Lei 5.478, art. 10; CLT, art. 849); i) as alegações finais serão verbais, no prazo de 10 minutos, após o que será renovada a proposta conciliatória, seguindo-se, caso esta resulte frustrada, a prolação da decisão (Lei 5.478, art. 11 ; CLT, art. 850); j) as partes reputar-se-ão intimadas da sentença na própria audiência (Lei 5.478, art. 12; CLT, art. 852). (TOLEDO FILHO; SOUTO MAIOR, 2003)

O princípio da intangibilidade do salário veda que o empregador proceda à descontos no salário do trabalhador, salvo nos casos autorizados por lei. A idéia por trás da norma é estabelecer limites às distorções que giram entorno dos descontos salariais. No entanto, o próprio TST editou súmula que viabiliza descontos não contidos em lei, supostamente em favor do empregado, mas que estabelece um perigoso precedente, a saber:

Súmula 342 TST: Descontos salariais efetuados pelo empregador, com a autorização prévia e por escrito do empregado, para ser integrado em planos de assistência odontológica, médico-hospitalar, de seguro, de previdência privada, ou de entidade cooperativa, cultural ou recreativa associativa dos seus trabalhadores, em seu benefício e dos seus dependentes, não afrontam o disposto pelo Art. 462 da CLT, salvo se ficar demonstrada a existência de coação ou de outro defeito que vicie o ato jurídico.

Esta súmula possibilita que o empregador efetue descontos não dispostos em lei, favorecendo assim distorções, como por exemplo, as empresas que não permitem ao empregado a não opção por plano de saúde por ela credenciado. Ao empregado que já tem plano de saúde particular e que, logicamente, não deseja participar do plano de saúde da empresa, visto que este oferece desconto em seu salário, tem esta opção negada pelo empregador, que não desejoso de mudar seu procedimento simplesmente ignora o pleito do trabalhador.

Uma recente inovação legislativa permite, à margem do princípio da intangibilidade, ou seja, sem observar a função normativa dos princípios ${ }^{95}$, descontos

\footnotetext{
95 A função fundamentadora dos princípios (ou função normativa própria) passa, necessariamente, pelo reconhecimento doutrinário de sua natureza norma jurídica efetiva e não simples enunciado programático não vinculante. Isso significa que o caráter normativo contido nas regras jurídicas integrantes dos clássicos diplomas jurídicos (constituições, leis e diplomas correlatos) estaria também presente nos princípios gerais de
} 
direto em folha de pagamento para empréstimos (empréstimos consignados), sob o argumento de que, desta forma, o trabalhador pode obter empréstimos a juros mais baixos do que o praticado em mercado. Ora, notórios são os efeitos perversos que inicialmente se extrai dessa prática, pois, pressionado pela dura realidade, o trabalhador solicitava empréstimos sequenciais, chegando a ponto de não receber salário, que restava integralmente comprometido.

Pode-se argumentar que a legislação foi sendo alterada para retirada dessas adiposidades, mas, ainda assim, é latente a falta de compromisso dessa norma com o referido princípio; ademais, não faz sentido o estabelecimento de uma norma que favoreça apenas um determinado setor econômico ou financeiro em detrimento de outros; pior ainda, em detrimento do salário do empregado.

Julgado muito interessante, abaixo colacionado, demonstra a possibilidade de, por meio de interpretação da norma, fundada nos princípios de direito de trabalho, pode se dar a conotação de dignidade ao trabalhador, inclusive superando obstáculos como a súmula 342:

\begin{abstract}
Seguro de vida. Desconto. Autorização. Inexistência. Devolução. O desconto efetuado a título de seguro de vida não afronta a regra de proteção contida no artigo 462 da CLT, já que o seguro de vida é fator de tranqüilidade para o trabalhador e para a sua família. Avanço no processo de conscientização do trabalhador e que exige do intérprete avaliação mais humana da regra legal restritiva, editada há mais de 50 anos. Nesse sentido, aliás, a Súmula 342 do TST. Entretanto, nada nos autos prova que o autor tenha concordado com o desconto. E é claro que não pode resultar de ato unilateral do empregador. Note-se que mesmo o entendimento firmado na Súmula exige prévia e expressa autorização do empregado. Prevalência do princípio da intangibilidade salarial. Recurso da ré a que se nega provimento. (TRT $2^{\mathrm{a}}$ Região, $11^{\mathrm{a}}$ T., p. 00849-2007481-02-00-4)
\end{abstract}

O princípio da não discriminação proíbe qualquer diferenciação, salarial ou de outra natureza, inclusive de acesso ao emprego, por motivo de sexo, idade, cor, crença, estado civil, dentre outros, conforme ditames constitucionais (artigo $5^{\circ}$ da $\mathrm{CF} / 88$ ), protegendo o trabalhador contra qualquer ação negativa de discriminação. É instrumento de efetivação de igualdade material, na medida em que impõe socialmente a convivência, no vertente 
caso em relação ao trabalho, de pessoas que, embora emparelhadas na questão da humanidade, mantém as mais distintas características e opções, e, a partir desse princípio, são respeitadas e inseridas no ambiente social, propiciando assim que o ser humano aprenda a conviver não apenas a partir das afinidades, mas especialmente a partir das diferenças.

A Lei no 11.644/2008 é exemplo recente de uma legislação que respeita o aspecto normativo dos princípios. O referido texto legislativo inseriu na CLT o artigo 442-A, inviabilizando que o empregador exija, quando do momento da seleção de candidato a emprego, experiência prévia por tempo superior a seis meses no mesmo tipo de atividade, impactando assim na contratação de jovens, setor atingido pela discriminação no trabalho, conforme se constatou anteriormente na pesquisa.

Um julgado do E. TST bastante noticiado na mídia nacional fez perceber como a interpretação pode, ao contrário do que aqui se deseja construir, fomentar a desigualdade entre os trabalhadores, afastando a efetividade que o conceito de trabalho decente pode instituir pela exegese, chocando ao ignorar a igualdade entre homens e mulheres e indicar distinção de indenização, porque homens não seriam ofendidos pela revista íntima como a mulher, notícia que merece transcrição literal:

A Quarta Turma do Tribunal Superior do Trabalho manteve a decisão regional que fixou valores diferentes de indenização por danos morais em razão do sexo do empregado submetido à revista íntima como forma de coibir furtos. De acordo com a decisão do Tribunal Regional do Trabalho de Alagoas (19 Região), as mulheres são mais sensíveis à exposição do corpo e à invasão de sua intimidade, enquanto os homens reagem de forma diferente ao estímulo, por isso a revista íntima não tem o mesmo efeito psicológico em ambos os sexos. Por unanimidade de votos, a Quarta Turma do TST rejeitou (não conheceu) recurso de um exempregado da loja de departamentos C\&A, de Maceió (AL), ao qual a loja terá de pagar $\mathrm{R} \$ 7.500,00$ de indenização por danos morais. $\mathrm{O}$ trabalhador recorreu ao TST alegando que a decisão regional violou o dispositivo constitucional que estabelece a igualdade de direitos entre homens e mulheres, na medida em que o TRT/AL assegurou indenização de R \$ 30 mil a uma ex-empregada da mesma loja, submetida a idêntico procedimento. De acordo com o relator do recurso, juiz convocado José Antonio Pancotti, a decisão não fere o princípio da igualdade nem caracteriza discriminação diante das características distintas de homens e mulheres. "O ordenamento constitucional veda diferenciações despropositadas, porque redundam em discriminações intoleráveis, quando se dá um tratamento desigual para casos iguais, revelando negação do ideal de Justiça. No presente caso, contudo, tratando-se de revista íntima, realizada no interior da empresa, vê-se que há mera diferenciação tolerável entre pessoas, em razão do sexo", afirmou. A revista íntima era feita num cubículo de dois metros quadrados - utilizado 
para guardar os produtos de limpeza da loja - onde os empregados ficavam, sozinhos ou em grupo, em trajes íntimos e sem os sapatos diante de um fiscal. Muitas vezes, de acordo com o relato dos autos, eram obrigados a tirar as roupas íntimas em razão da suspeita de que estivessem escondendo algo no corpo. A defesa da empresa sustentou que o procedimento estava autorizado por convenção coletiva, era feito sempre por pessoa do mesmo sexo do revistado, de forma indiscriminada e moderada. (TST - RR 2008/2001-001-19-00.2).

Um outro ponto importante tocado pelo principio da não discriminação respeita à questão da diferença medida pela raça. Infelizmente, são poucos os casos que chegam à Justiça do Trabalho, tendo em vista que se expor novamente em audiência, relatando o acontecido e colocando-se frente-a-frente com o agressor, são fatos que o agredido não quer viver/reviver. Ademais, nossa cultura de país escravagista ainda tolera a discriminação disfarçada em anedota; aliados ao medo de perder o emprego e a baixa estima que é imposta aos negros, os casos de discriminação por cor, que certamente ocorrem aos borbotões diariamente, não alcançam a via da Justiça no mesmo número. Além disso, a falta de critério para o estabelecimento de indenizações mitiga o problema levado à resolução institucional, afastando ainda mais estes casos do Poder Judiciário:

De se ver - provado pelas provas orais, inclusive pelas testemunhas convidadas pela Reclamada - que era permitido, e mesmo considerado normal, o tratamento acintoso do coordenador, e que passou a existir também entre os funcionários, no local de trabalho. (...) Nem se dizer que a reação da obreira era excessiva, por melindres exacerbados, eis que "nariz de batata" e "urubu" não são propriamente apelidos carinhosos, a demonstrar a sua plena aceitação no ambiente de trabalho. Não, ao revés, é uma forma de exposição social maldosa e levando o grupo, em dinâmica própria e cruel, a se colocar, até sem motivo plausível, contra a Reclamante, desenrolando-se essa ação em um círculo vicioso perverso, sempre prejudicando a tranqüilidade, a paz e a boa formação psicológica da Autora. (TRT $2^{\mathrm{a}}$ região, Acórdão 20050001706)

Outro argumento muito utilizado na questão da discriminação racial diz respeito a que a discriminação pode ter cunho pessoal, entre agressor e agredido, retirando-se assim qualquer responsabilidade do empregador na manutenção de um bom ambiente de trabalho, conforme demonstra o julgado abaixo colacionado: 
racial, cuja imputação seria atribuída ao chefe imediato do reclamante, não implica no endosso do empregador e nem pode causar efeitos na relação de trabalho. Ademais, a reclamada é uma empresa paraestatal e só seria responsável por atos de sua direção e não das chefias de pequeno escalão.( TST, E-RR 381.531/97)

Também se pode destacar outras formas de discriminação ainda mais veladas, relacionadas aos pobres, aos trabalhadores braçais, aos trabalhadores rurais. Dificilmente seria possível avistar a argumentação abaixo adotada se o trabalhador litigante fosse um diretor de empresa:

EMENTA: DANOS MORAIS. TRANSPORTE INADEQUADO. AUSÊNCIA DE OFENSA À DIGNIDADE HUMANA. Poder-se-ia questionar no âmbito administrativo uma mera infração das normas de trânsito do Código de Trânsito Brasileiro quanto ao transporte inadequado de passageiros em carroceria de veículo de transporte de cargas, o que não é da competência da Justiça do Trabalho. Mas se o veículo é seguro para o transporte de gado também o é para o transporte do ser humano, não constando do relato bíblico que Noé tenha rebaixado a sua dignidade como pessoa humana e como emissário de Deus para salvar as espécies animais, com elas coabitando a sua Arca em meio semelhante ou pior do que o descrito na petição inicial (em meio a fezes de suínos e de bovinos). (TRT3, p. 01023-2002-081-03-00-0, 7ª T., Rel. Milton Vasques Thibau de Almeida)

O princípio da irredutibilidade do salário infere que o salário não pode ser reduzido apenas pela simples vontade do empregador. Ora, se o salário é o meio de vivência do trabalhador e se é através dele que se atinge os bens da vida, consumindo os produtos e demais bens fundamentais na manutenção humana, por óbvio que a instabilidade social seria uma séria consequência se houvesse a possibilidade de redução de salário, daí porque a proibição constante no princípio.

Isso não significa que o legislador tenha se atentado, mais uma vez, à função normativa dos princípios. Senão vejamos. Primeiramente, vale lembrar que a correção salarial não é mais instituída por lei a partir da edição da Lei no 8.880/94 - Programa de Estabilização Econômica. A partir desse marco, as partes devem negociar as perdas salariais nas respectivas datas-base. 
O princípio da inalterabilidade das condições contratuais aduz que as alterações contratuais somente na medida em que o empregado não sofra prejuízo direto ou indireto decorrente dessa alteração, ainda que o empregado anua à mudança. consoante o previsto no artigo 468, caput, da CLT.

Outro exemplo de alteração que se instala no contrato, e que não observou que os princípios norteiam a atividade legislativa (e constituinte) foi a instituição em sede constitucional da possibilidade de redução de salário com a intervenção dos sindicatos. Sem adentrar profundamente na questão da representatividade dos sindicatos, é notória a crise que existe neste sentido. Pois bem, o constituinte de 88 entendeu que, se o sindicato pactuar uma redução salarial, esta seria possível. Otávio Bueno Magano passou então a divulgar a doutrina do "quem pode o mais pode o menos". Entendia aquele doutrinador que se foi concedido ao empregador a redução do salário (segundo ele, bastando para tanto apenas a condição de ter sido intermediada pelo sindicato), e este é senão o mais, um dos mais resguardados direitos do trabalhador, outras reduções seriam possíveis. Tal doutrina foi difundida a ponto de servir de fundamento nos próprios instrumentos coletivos para diminuição sem limites dos direitos trabalhistas. É o que se faz ver da Convenção Coletiva abaixo colacionada:

Esclarecimento Final: Fica esclarecido a título de cautela, que as Cláusulas aqui pactuadas, em face ao que dispõe o Artigo $7^{\circ}$ da Constituição Federal, especialmente em seu Inciso XXVI, tem eficácia equivalente à lei. O presente pacto exclui a aplicação do Precedente 119 do C. TST, posto que, exatamente para evitar-se a aplicabilidade de tal Precedente que as partes fazem aqui concessões até tornar possível o presente pacto.Ressalte-se que o mesmo art. $7^{\circ}$, em seus incisos VI, XIII e XIV, atribui à Convenção Coletiva de Trabalho poderes acima da lei e o princípio geral de direito, "quem pode o mais pode o menos." (g.n.) Ademais, é condição ajustada na presente Convenção Coletiva de Trabalho a adoção do entendimento do Supremo Tribunal Federal, nos Recursos Extraordinários n. 189.960-3 e 337.718-3, conforme explicitado na Cláusula 74 supra, dado que a contribuição aqui adotada é apenas aquela autorizada pelo Art.513, "e", da Consolidação das Leis do Trabalho. (CCT SINTHORESP 2009)

Destarte, procurou-se aqui estabelecer a importante ligação entre a aplicação da interpretação das questões trabalhistas considerando-se os princípios basilares do Direito do Trabalho e suas funções, que o distinguem como ramo autônomo do Direito e concedem contornos de natureza social de interesse público, afastando-se assim qualquer possibilidade de aplicação de uma lógica privatística que não condiz com a relação de 
trabalho. Note-se que a observância desses princípios não se limita ao Poder Judiciário, mas igualmente ao Poder Legislativo na edição ou na reforma de leis, como se quis acima demonstrar, e também ao Poder Executivo, especialmente na criação e desenvolvimento de políticas públicas relacionadas ao trabalho.

\subsection{O conceito de trabalho decente}

Trabalho decente, assim, é o trabalho não intermediado em qualquer circunstância, nem terceirizado, a fim de que não haja precarização das condições de labor, evitando-se, portanto, a super exploração do empregado.

Note-se que a precarização do trabalho não depende exclusivamente de ele ser intermediado, posto que, moderna e contemporaneamente, as formas (novas ou não) de gestão dos recursos humanos possibilitam o que convencionou chamar de neoescravidão ${ }^{96}$, ou seja, apesar do trabalhador estar regularmente contratado, por meio de contrato de emprego (que como já se afirmou, é o que melhor se adequa à questão da dignidade do trabalhador), a flexibilização/desregulamentação trabalhista atingiu tão fortemente a legislação protetiva, que, mesmo dentro dos parâmetros do direito escrito, representa o aviltamento da dignidade do trabalhador, porque o lança a uma condição degradante de trabalho, por meio de baixíssimos salários, longas jornadas extraordinárias (basta pagar o adicional para ter a situação regularizada, conforme se depreende da maioria dos jugados), dentre outros motivos. Por este motivo, o conceito tem de transparecer que qualquer forma de precarização não é condizente com a dignidade do trabalhador.

O trabalho decente deve ser objetivo das políticas econômicas, cuja finalidade deve se voltar à realização do bem comum e da justiça social, para que o trabalhador aufira renda suficiente em consonância com a digna manutenção de sua vida e de sua família, renda esta que deve corresponder a um montante que seja equacionado pelas necessidades humanas, cujo parâmetro pode ser visto no artigo $7^{\circ}, \mathrm{IV}$, da $\mathrm{CF} / 88^{97}$ :

\footnotetext{
${ }^{96}$ Por óbvio que o trabalho escravo, também designado como trabalho análogo ao de escravo, é das piores formas de trabalho degradante; quando se fala em neo-escravidão, refere-se a uma forma, ainda que em de maneira transversa, também degradante, porque, apesar de diferentemente do trabalho escravo, manter a aparência de legalidade, também ofende a dignidade do trabalhador.

${ }^{97}$ Este conceito pode ser utilizado mesmo em outros Estados Soberanos, pois a aludida norma constitucional contempla necessidades humanas universais.
} 
Art. $\mathbf{7}^{\mathbf{0}}$, IV - salário mínimo, fixado em lei, nacionalmente unificado, capaz de atender a suas necessidades vitais básicas e às de sua família com moradia, alimentação, educação, saúde, lazer, vestuário, higiene, transporte e previdência social, com reajustes periódicos que lhe preservem o poder aquisitivo, sendo vedada sua vinculação para qualquer fim.

Por óbvio que o salário mínimo nacionalmente instituído não dá condições concretas de atingimento desse padrão estipulado pelo art. $7^{\circ}$, motivo pelo qual ele deve corresponder materialmente a essas necessidades, estando assim condicionado pelo comando constitucional. Para se auferir este valor, deverá ser utilizado índices que atribuam valores a cada uma dessas necessidades e retire daí a média razoável para estipulação do montante.

Pode-se afirmar que o conceito de trabalho decente trazido pela OIT peca especialmente no contexto que lhe é atribuído pelos doutrinadores patrocinados pelo Órgão, como já se pode estabelecer. Numa singela leitura, pode-se imaginar que, quando o Instituto Internacional harmoniza com o propósito da dignidade no labor termos como emprego, segurança, etc., não contextualiza no conceito o sentido protecionista que se espera daquela sentença.

O que se pode perceber é que o Órgão acaba por instituir parâmetros pouco influentes na questão da eficácia daqueles elementos, porque os intérpretes concedem àquelas palavras significados que distanciam o conceito da eficácia que pode lhe ser conferida, se ele servisse de parâmetro para os debates (inclusive interpretação humanista) das questões trabalhistas, sejam por meio de normas, julgados ou políticas públicas.

Assim, conclui-se que trabalho decente deve ser conceituado como o trabalho da espécie emprego subordinado, contratado diretamente por quem se favorece dos serviços prestados, protegido concretamente pelo ordenamento jurídico imperativo que limite o exercício potestativo da autonomia da vontade do empregador, para que não seja precarizado mesmo quando formalizado, pelo qual o trabalhador aufira renda compatível com a manutenção real de sua vida e de sua família, exercendo a atividade laborativa com igualdade, segurança, liberdade, consciência e dignidade. $O$ trabalho decente deve ser parâmetro para instituição ou interpretação de quaisquer políticas públicas, inclusive as econômicas, haja vista que estas se obriguem na objetivação da justiça social, motivo pelo 
qual deve ser respaldado na democracia participativa através da criação e fomento de espaços públicos que propiciem a participação popular independente. 


\section{CONCLUSÃO}

Analisando o conceito de trabalho decente proposto pela OIT, pôde-se auferir que, ainda que traga elementos importantes na caracterização do fenômeno, mantém essa concepção uma abrangência que permite, dentro de um mesmo grupo social, chegar a conclusões bastante distintas, fato que em si não pesa contra a promoção de um ambiente laboral menos hostil, mas que na realidade acaba por possibilitar construções teóricas que desprotegem o trabalhador. Possibilita interpretações que, ao invés de serem instrumentos no combate do trabalho degradante, servem muitas vezes de fundamentação para a perpetuação da exploração desmedida, a exemplo de doutrinadores patrocinados pelo órgão entenderem que não apenas o emprego subordinado, mas outras formas de trabalho contemplam o trabalho decente, sem oferecer uma solução que equacione a falta de proteção legal que tangencia as outras modalidades de trabalho.

A exclusão social, ao contrário do que crê o senso comum, não é ocasionada necessariamente pela pobreza, e pode-se perceber pelos dados coletados que o desemprego e o trabalho degradante são fatores que a promovem. O desemprego empurra o indivíduo para as piores condições de trabalho, porque notadamente, quem não tem emprego subordinado, para sobreviver, aceita prestar serviços no mercado informal, que, sem ou com pouquíssimo regramento legal que limite a imposição de condições pelo contratante que se servirá dos serviços, encontra ambiente propício para absorver sem qualquer medida da força de trabalho humana, que, sem opção, dada a pressão concreta pela sobrevivência que se impõe, acaba lançando o trabalhador para a realização de trabalho degradante.

Existem pessoas que têm concretamente opção de escolha, mas são exceções no mundo do trabalho. Não se ignora que a maioria dos indivíduos não tem materialmente opção de escolha entre este ou aquele posto de trabalho, por dois motivos. Primeiramente, porque concretamente dependem da renda obtida pelo trabalho para sobreviver, o que os faz aceitar trabalhos nem sempre condizentes com sua condição humana; em segundo lugar, o fato de trabalhar neste ou naquele posto de trabalho, em si, não modifica as condições de labor, porque determinados setores têm suas ações de direção da mão-deobra, de certa maneira, padronizadas.

A título de exemplo dessa realidade, destacam-se os problemas trabalhistas no setor de telemarketing - que não por acaso terceiriza mão de obra. O setor em si estabelece um meio ambiente de trabalho que é degradante, dada a forma como direcionam a mão-de- 
obra, obtendo máxima exploração, de forma desumana e desmedida. Pode ser salientada uma decisão proferida em 2009 pela $7^{\text {a }}$ Turma do TST que considera lícita a estipulação de controle de tempo para ir ao banheiro para trabalhadores de call center, alegando que não consta dos autos que houve proibição caso o obreiro quisesse ir ao banheiro:

Não constitui dano moral a exigência patronal de solicitação de
permissão para ir ao banheiro, no caso de trabalho em call center, tendo
em vista a concessão de intervalos para a satisfação de necessidades
fisiológicas e a dificuldade de operação do centro de atendimento no caso
de vários empregados se ausentarem simultaneamente de seus postos de
trabalho, não constando, no caso, que houvesse proibição ou
constrangimento do empregado na ida ao toalete, que atentasse contra a
intimidade ou imagem do trabalhador. (TST, RR - 2123/2007-013-18-00)

Este julgado demonstra como o conceito de trabalho decente que não se baseia nos princípios protetores do trabalhador pode gerar interpretação que perpetua uma situação degradante de labor. O princípio protetor foi abandonado nesta perspectiva, porque, obviamente, a autonomia da vontade do empregador se sobrepôs aos direitos de personalidade do trabalhador. Ademais, se não houvesse nenhum óbice a que o empregado utilizasse o banheiro quando fisiologicamente fosse necessário, para que o empregador iria controlar esse lapso?

No entanto, o TST, por sua $3^{\text {a }}$ Turma, prolatou sobre o mesmo assunto uma decisão que reverencia o conceito de trabalho decente, porque, considerando que o empregador abusou de seu poder diretivo, ou seja, que o poder diretivo deve ter limites na dignidade do trabalhador, fundamentou a decisão nos princípios basilares do Direito do Trabalho princípio protetor, bem como nos princípios de direitos humanos - princípio da igualdade, atribuindo assim eficácia ao conceito de trabalho decente:

INDENIZAÇÃO POR DANO MORAL. CONTROLE DO TEMPO DE UTILIZAÇÃ̃O DOS TOALETES. Concebendo o dano moral como a violação de direitos decorrentes da personalidade (...) $\mathrm{O}$ fato de o empregador exercer de forma abusiva seu poder diretivo - art. $2^{\circ}$ da CLT, com a utilização de práticas degradantes imprimidas à coletividade de trabalhadores, de modo a simular o respeito ao princípio da igualdade, não descaracteriza a violação dos direitos de personalidade, à honra, à imagem, à própria dignidade da pessoa humana, constitucionalmente consagrada (art. $\left.1^{\circ}, \mathrm{III}\right)$. A Corte regional consigna expressamente que a empregadora controlava a ida dos trabalhadores ao banheiro - limitada 
apenas a uma por dia, estando as demais idas sujeitas à justificação-, bem como o tempo gasto com suas necessidades fisiológicas - 5 (cinco) minutos-, reconhecendo ser prática adotada indistintamente - alcançando todos os trabalhadores do setor. A prática descrita pelo Tribunal de origem configura descumprimento por parte do empregador dos deveres decorrentes da boa-fé, onde se encontra o dever de zelar pela segurança e bem-estar do empregado no ambiente de trabalho. A afronta à dignidade da pessoa humana aliada ao abuso do poder diretivo do empregador ensejam a condenação ao pagamento de compensação por dano moral. (RR-167500-63.2008.5.18.0009)

O conceito de trabalho decente apresentado ainda é um conceito indeterminado, mas por conta dos elementos identificados que o compõem, e das diretrizes que foram impressas, torna-se mais objetivo que o criado pela OIT, indicando claramente que o trabalho intermediado não pode estar em consonância com a dignidade do trabalhador, e que o emprego subordinado, devido à proteção legal que o cerca, é a espécie de trabalho que mais aproxima o trabalhador de um ambiente de trabalho digno, haja vista que estabelece limites à autonomia da vontade do empregador. Para que as questões relacionadas ao trabalho, tão sensíveis ao proletariado, possam ser conhecidas e debatidas, calibrando assim o conceito de trabalho decente, é fundamental que haja a promoção e o desenvolvimento da democracia participativa e a criação e propagação de espaços públicos.

A presente pesquisa intencionou apresentar, portanto, um conceito de trabalho decente pode ser parâmetro para alterações legislativas, inclusive de cunho constitucional, para criação e efetivação de políticas públicas de emprego, bem como ser critério de interpretação ao Poder Judiciário, especialmente para concretizar de forma imperativa limites à autonomia da vontade do empregador, que é a parte mais forte da relação de emprego e acaba por dominar a vontade do empregado, submetido a condições desumanas de trabalho pelas necessidades e obstáculos que a vida concretamente impõe, e o direito nem sempre considera. O trabalho decente deve ser instrumento de promoção da justiça social.

Assim, conclui-se que trabalho decente deve ser conceituado como o trabalho da espécie emprego subordinado, contratado diretamente por quem se favorece dos serviços prestados, protegido concretamente pelo ordenamento jurídico imperativo que limite o exercício potestativo da autonomia da vontade do empregador, para que não seja precarizado mesmo quando formalizado, pelo qual o trabalhador aufira renda compatível com a manutenção real de sua vida e de sua família, exercendo a atividade laborativa com 
igualdade, segurança, liberdade, consciência e dignidade. $\mathrm{O}$ trabalho decente deve ser parâmetro para instituição ou interpretação de quaisquer políticas públicas, inclusive as econômicas, haja vista que estas se obriguem na objetivação da justiça social, motivo pelo qual deve ser respaldado na democracia participativa através da criação e fomento de espaços públicos que propiciem a participação popular independente. 


\section{REFERÊNCIAS}

ALEXY, Robert. Teoria dos Direitos Fundamentais. São Paulo: Malheiros, 2008

AMARAL, Lígia Assumpção. Mercado de trabalho e deficiência. Cadernos de educação especial, Santa Maria: n. 2, p. 127-136, 1994. Disponível em: <http://http//www.ufsm.br/ce/revista $>$. Acesso em: 12 jun 2010.

AMORIM, Andresa Silva de. Terceirização e desidentidade sindical: uma (ou mais uma?) estratégia ideológica do capital. Cientefico. Ano VII, v. II, p.314. Salvador, julhodezembro 2007.Disponível em: <http://www.frb.br/ciente/dossie/dossie_amorim.pdf >. Acesso em 12 jan. 2010.

AMORIM, Wilson. Crise econômica recente e negociações coletivas no Brasil: algumas lições? Revista Administração em Diálogo, n. 13, v. 2, 2009, p. 01-18.

ARENDT, Hannah. A condição humana. 10.ed. Rio de Janeiro: Forense Universitária, 2000 .

. As origens do totalitarismo. Rio de Janeiro: Documentário, 1979.

ARISTÓTELES. A política. São Paulo: Ícone, 2007.

ASSOCIAÇÃO BRASILEIRA DOS EXPOSTOS AO AMIANTO. Disponível em: <http://www.abrea.com.br/inicial.html>. Acesso em: 13 nov. 2005.

BALAM, Daniel Gonçalves. Interpretação constitucional da proteção contra a dispensa do empregado. Revista do Departamento de Direito do Trabalho e da Seguridade Social da FADUSP. São Paulo, v. 2, n. 3, jan/jun 2007, p. 113-171.

BENJAMIN, César et al. A opção brasileira. Rio de Janeiro: Contraponto, 1998.

BERGMANN, B. In defense of affirmative action. New York: BasicBooks, 1996.

BARRETOS, Vicente de Paulo (Coordenador). Dicionário de Filosofia do Direito. São Leopoldo: Unisinos; Rio de Janeiro: Renovar, 2006.

BARROS, Guilherme. Brasil está perto do pleno emprego, diz Lupi. 15 jul 2010. Disponível em: < http://colunistas.ig.com.br/guilhermebarros/2010/07/15/brasil-esta-pertodo-pleno-emprego-diz-lupi/>. Acesso em: 17 ago. 2010.

Constituição (1988). Disponível em <http://www.planalto.gov.br/ccivil_03/constituicao/constitui\%C3\%A7ao.htm>. Acesso em: 02 jan. 2010.

BAUMAN, Zygmunt. Confiança e medo na cidade. Rio de Janeiro: Zahar, 2009. 
BOMBANA, José A. Somatização e conceitos limítrofes: delimitação de campos. Psiquiatria na prática médica. São Paulo.v. 34, n. 4, 2001/2002. Disponível em: <http://www.unifesp.br/dpsiq/polbr/ppm/atu2_01.htm>. Acesso em: 12 out. 2010.

BOTTON, Alexandre Mariotto. Autonomia da vontade e interesse moral em Kant. 2005. Dissertação (Mestrado em Direito) — Universidade Federal de Santa Maria - Rio Grande do Sul.

CANOTILHO, J. J. Gomes; CORREIA, Marcus Orione Gonçalves; CORREIA, Érica Paula Barcha. Direitos fundamentais sociais. São Paulo: Saraiva, 2010.

CARVALHO, Suzete. A interpretação jurídica e as perspectivas do Direito do Trabalho. 1994. Dissertação (Mestrado em Direito) — Faculdade de Direito da Universidade de São Paulo, São Paulo.

CAUPERS, João. Os Direitos Fundamentais dos trabalhadores e a Constituição. Lisboa: Almedina, 1985.

CHAUÍ, Marilena. Convite à filosofia. 13. ed. São Paulo: Ática, 2005.

COMPARATO, Fábio Konder. A afirmação histórica dos Direitos Humanos. 3. ed. São Paulo: Saraiva, 2003.

COSTA, Mário Júlio de Almeida. Direito das Obrigações. 3. ed., Coimbra: Editora Almedina, 2000.

COSTA, Orlando Teixeira Filho da. Direito Alternativo ou Flexibilização. In Revista de Direito do Trabalho LTr. São Paulo: LTr, n. 56, 1992, p. 779.

CRUZ, Paulo Márcio. Democracia e Cidadania. Revista Novos estudos jurídicos, ano V, n. 10 p. 107-116, abr. 2000. Disponível em: <https://www6.univali.br/seer/index.php/nej/article/view/1539/1236>. Acesso em: 18.05.08.

DEJOURS, Christophe. A banalização da injustiça social. Rio de Janeiro: Editora FGV, 2007.

DELGADO, Maurício Godinho. Curso do Direito do Trabalho. 7. ed., São Paulo: Ltr, 2008.

Princípios de direito individual e coletivo do trabalho. São Paulo: LTr, 2001.

DEPARTAMENTO INTERSINDICAL DE ESTATÍSTICA E ESTUDOS SÓCIOECONÔMICOS. Pesquisa de emprego e desemprego: especial mulher 2010, anexo de estatísticas. 2010a. Disponível em: <http://www.dieese.org.br/ped/sp/pedspMulher2010AnexoEstatistico.pdf>. Acesso em: 10 jul. 2010.

Pesquisa de emprego e desemprego: especial mulher 2010. 2010b. Disponível em: <http://www.dieese.org.br/ped/sp/pedspMulher2010.pdf>. Acesso em: 10 jul. 2010. 
Pesquisa de emprego e desemprego: especial negro 2009. 2009. Disponível em: <http://www.dieese.org.br/ped/sp/negrormsp2009.pdf> . Acesso em: 10 jul. 2010.

$\underset{\text { persiste }}{\text { Pesquisa de emprego e desemprego: desigualdade entre negros e não-negros ainda }}$ <http://www.dieese.org.br/ped/sp/negrormsp2008.pdf>. Acesso em: 10 jul. 2010.

DIAS, Solange Gonçalves. Democracia representativa $x$ democracia participativa: Participação popular no plano local e emergência de um novo paradigma democrático. 2001. Dissertação (Mestrado em Direito) — Faculdade de Direito da Universidade de São Paulo, São Paulo.

DINIZ, Maria Helena. Curso de direito civil brasileiro: responsabilidade civil. 24. ed. São Paulo: Saraiva, v. 7, 2010.

DUPAS, Gilberto. A lógica da economia global e a exclusão social. Estud. av. [online]. 1998, vol.12, n.34, pp. 121-159.

DWORKIN, Ronald. Levando os direitos a sério. 2. ed. São Paulo: Martins Fontes, 2007.

EBERHARD, Christoph. O Direito no mundo globalizado: em direção à "boa governança" através do dialogo intercultural. In Revista Direito, Estado e Sociedade, n.33, jul/dez 2008, p. 6 a 18.

ESCOREL, Sarah. Exclusão social fenômeno totalitário na democracia brasileira. Saúde e Sociedade, 1993, vol.2, n.1, p.41-57.

EUROPA. União Européia. EUR-Lex n. 41989X1031. Resolução do Conselho e dos Ministros dos Assuntos Sociais, reunidos no seio do conselho de 29 de Setembro de 1989 relativa à luta contra a exclusão social. Disponível em: <http://eurlex.europa.eu/Notice.do?mode=dbl\&lang=es\&ihmlang=es\&lng1=es,pt\&lng2=da,de,en,es,f r,it,nl,pt,\&val=151353:cs\&page=>. Acesso em:: 21 jul. 2010.

FEMENÍA, Ana María García; VALENZUELA, Emilio Morgado; CATRY, Marleen Rueda. Diálogo Social Institucionalizado en América Latina: Estudio comparado de Argentina, Brasil, Ecuador,México y Perú. Proyecto "Fortalecimiento de los mecanismo institucionales para el diálogo social" Lima: OIT, 2007.

FERNANDES, Antônio Sérgio Araújo. Políticas Públicas: Definição, Evolução e o Caso Brasileiro. Disponível em <http://200.155.18.61/informacao/b6d71ce_114f59a64cd_7fcc.pdf>. Acesso em: 04.08.07.

FERRAREZI, Elisabete. Estado e setor público não estatal: perspectivas para a gestão de novas políticas $\quad$ sociais. $1997 . \quad$ Disponível <http://www.anesp.org.br/userfiles/file/estudos/estado_setor.pdf>. Acesso em $12 \mathrm{dez}$. 2010.

FIORI, José Luis da Costa . A governabilidade democrática na Nova Ordem Econômica. Revista Novos Estudos - CEBRAP, Rio de Janeiro, v. 43, 1995. 
FISCHER, G.N. Psicologia social do ambiente. Lisboa: Instituto Piaget, 1994.

FONSECA, Ricardo Marcelo. Modernidade e contrato de trabalho: do sujeito de direito à sujeição jurídica. São Paulo: LTr, 2001.

GASPAR, Ricardo; AKERMAN, Marco; GARIBE, Roberto (Org.). Espaço urbano e inclusão social: a gestão pública na cidade de São Paulo 2001-2004. São Paulo: Editora Fundação Perseu Abramo, 2006.

GHAI, Dharam. Decent work: Universality and diversity. In: INTERNATIONAL LABOUR OFFICE. Decent work: objectives and strategies. 2006. Disponível em: <http://www.ilo.org/public/english/bureau/inst/download/decentghai.pdf >. Acesso em: 13 out. 2009.

GOMES, Orlando. Contratos. 18. ed. Rio de Janeiro: Forense, 1998.

GOSDAL, Thereza Cristina. Dignidade do trabalhador: um conceito construído sob o paradigma do trabalho decente e da honra. São Paulo: Ltr, 2007.

GRAU, Eros Roberto. Nota sobre os conceitos jurídicos. In Revista de Direito Público, $\mathrm{n}^{\circ}$ 74, São Paulo: RT, abril/junho, 1985, p. 217-221.

GUEDES, Márcia Novaes. Terror Psicológico no trabalho. 3. ed. São Paulo: LTr, 2008.

GUEIROS JÚNIOR, Samuel; LOPES, Aírton da Silva. Globalização, flexibilização e desregulamentação: modelos emergentes para a inspeção do trabalho. 2000. Disponível em: <www.saudeetrabalho.com.br/download/samuel-airton.doc >. Acesso em $08 \mathrm{dez}$. 2010 .

HARLOE, Michael. Marxismo, Estado e questão urbana. Espaço \& Debates. 28:80-100, 1989.

HOLMES, Stephen; SUNSTEIN, Cass. The Cost of Rights: Why Liberty Depends on Taxes. New York: W. W. Norton \& Company, 2000.

IGREJA CATÓLICA APOSTÓLICA ROMANA. Encíclica Rerum Novarum. 1891. Disponível em: <http://www.vatican.va/holy_father/leo_xiii/encyclicals/documents/hf_lxiii_enc_15051891_rerum-novarum_po.html>. Acesso em: 17 jun. 2010.

· Encíclica Rerum Novarum. 1891. Disponível em: <http://www.vatican.va/holy_father/pius_xi/encyclicals/documents/hf_pxi_enc_19310515_quadragesimo-anno_po.html>. Acesso em: 17 jun. 2010.

INSTITUTO ANTÔNIO HOUAISS. Dicionário Eletrônico Houaiss 2009. São Paulo: Ed. Objetiva, 2009. 1 CD-ROM. 
INSTITUTO GRASILEIRO DE GEOGRAFIA E ESTATÍSTICA. Censo Demográfico 2000 .

Disponível em:

http://www.ibge.gov.br/home/presidencia/noticias/27062003censo.shtm>. Acesso em: 13 out. 2010.

KANT. Immanuel. Fundamentação da metafísica dos costumes. Lisboa: Edições 70, 2005.

KASHIURA JR., Celso Naoto. Crítica da igualdade jurídica: contribuição ao pensamento jurídico marxista. São Paulo: Quartier Latin, 2009.

KEYNES, John Maynard. A teoria geral do emprego, do juro e da moeda. São Paulo: Atlas, 1982.

KLEIN, Naomi, Sem Logo. Rio de Janeiro: Record, 2002.

LAI, Richard. The fate of a generation of workers: Foxconn undercover fully translated. 2010. Disponível em: < http://www.engadget.com/2010/05/19/the-fate-of-a-generation-ofworkers-foxconn-undercover-fully-tr/>. Acesso em: 12 out. 2010.

LOPES, Miguel de Serpa. Curso de Direito Civil. v.1, 8. ed. Rio de Janeiro: Freitas Bastos, 1996.

LŨNO, Antonio E. Perez. Los derechos fundamentales, 7. ed. Madri: Tecnos, 1998

MAGANO, Octávio Bueno. $A B C$ do Direito do Trabalho. São Paulo: Revista dos Tribunais, 1998.

MARICATO, Ermínia; SANTOS JR., Orlando Alves dos. Construindo a Política Urbana: participação democrática e o direito à cidade. 2006. Disponível em: <http://www.undp.org/Legalempowerment/reports/National\%20Consultation\%20Reports/ Country\%20Files/7_Brazil/7_5_Urban_Policy.pdf>.Acesso em 23 set. 2010.

MARX, Karl. H. O Capital - Parte III: A Produção de Mais Valia Absoluta. ca2004. Disponível em: < http://www.dominiopublico.gov.br/download/texto/ma000067.pdf>. Acesso em: 07.09.10.

. Manuscritos econômico-filosóficos. São Paulo: Boitempo, 2008.

Coleção "Os Pensadores". São Paulo: Editota Abril, 1974.

; ENGELS, Friedrich. A ideologia alemã teses sobre Feuerbach. 9. ed. São Paulo: Centauro, 2006.

. Manifesto do Partido Comunista. São Paulo: Editora Martin Claret, 2000.

. O 18 brumário de Luis Bonaparte. São Paulo: Escriba, 1968. 
MAXIMILIANO, Carlos. Hermenêutica e aplicação do direito, Rio de janeiro, 16. ed. Forense, 1996.

MERRIEN, François Xavier. L'État-providence. Paris: Armand Colin, 2004.

MÉXICO. Constituição Mexicana de 1917. Disponível em: http://www.dhnet.org.br/inedex.htm>. Acesso em: 20 nov. 2006.

MINISTÉRIO DO TRABALHO E EMPREGO. Trabalho decente nas Américas: a consolidação de um caminho comum. - Brasília: MTE, Assessoria Internacional, 2006. Disponível em: <http://www.mte.gov.br/rel_internacionais/pub_revistaIV.pdf>. Acesso em: 24 jun. 2008.

Agenda nacional de trabalho decente. 2006. Disponível em:

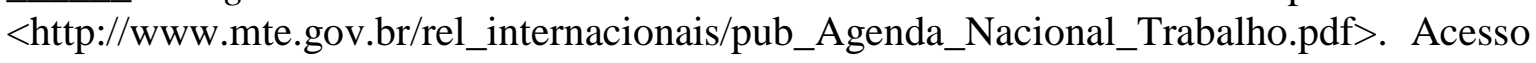
em: 24 mar. 2010.

MINISTÉRIO PÚBLICO DO TRABALHO. Codin - discriminação, assédio, trabalho escravo $e$ trabalho degradante. 2010. Disponível em: <http://www.prt2.mpt.gov.br/codin/discriminacao.php>. Acesso em: 10 ago. 2010.

MIRANDA, Jorge. Manual de Direito Constitucional. Tomo IV, 2. ed. Coimbra: Coimbra, 1988.

MOSTEIRO DE SÃO BENTO DO RIO DE JANEIRO. Regra do Glorioso Patriarca São Bento. 2010. Disponível em: <http://www.osb.org.br/regrasaobento.html\#CAPÍTULO\%2048>. Acesso em 21 nov. 2010 .

NASCIMENTO, Elaine Ferreira do. A perda da razão social do trabalho: terceirização e precarização. Ciênc. saúde coletiva [online]. 2008, vol.13, n.3, pp. 1093-1094.

NAVES, Márcio Bilharinho. Marx: ciência e revolução. 2. ed. São Paulo: Quartier Latin, 2008.

NERI, Marcelo. Retratos da deficiência no Brasil. Rio de Janeiro: FGV, IBRE, CPS, 2003. Disponível <http://www.fgv.br/cps/deficiencia_br/PDF/PPD_Sumario_Executivo.pdf >. Acesso em: 13 out 2010 .

NOGUEIRA, Marco Aurélio. Para uma governabilidade democrática progressiva. Revista Lua Nova, Vol. 36, p. 105-128, São Paulo: CEDEC, 1995.

ORGANIZAÇÃO DAS NAÇÕES UNIDAS. Programa das nações unidas para o Desenvolvimento. Disponível em pnud <http://www.pnud.org.br/gerapdf.php?id01=228>. Acesso em: 02 jan. 2010. 
ORGANIZAÇÃO INTERNACIONAL DO TRABALHO. Trabalho decente nas Américas: uma agenda hemisférica, 2006-2015. 2006a. Disponível em <http://www.oitbrasil.org.br/info/downloadfile.php?fileId=232>. Acesso em: 06 jun 2009.

ECOAR - Educação, Comunicação e Arte na Defesa dos Direitos da Criança e do Adolescente. Brasília: OIT - 2007.

Constituição da Organização Internacional do Trabalho. 1946. Disponível em <http://www.oitbrasil.org.br/info/download/constituicao_oit.pdf>. Acesso em: 05 mai. 2009.

. Declaração referente aos fins e objetivos da Organização Internacional do Trabalho (Declaração de Filadélfia). 1944. Disponível em <http://www.oitbrasil.org.br/info/download/constituicao_oit.pdf>. Acesso em: 05 mai. 2009.

Convenção n. 122 relativa à política de emprego. 1964. Disponível em <http://www.ilo.org/ilolex/spanish/convdisp1.htm>. Acesso em: 05 mai. 2009.

Perfil do Trabalho Decente no Brasil. 2009. Disponível em <http://www.oitbrasil.org.br/topic/decent_work/doc/perfiltdbrasil_129.pdf>. Acesso em: 02 jan. 2010.

Projeto diálogo social. 2005. Disponível em < http://white.oit.org.pe/portal/documentos/ds_evento_sao_paulo_triptico.pdf $>$. Acesso em: 05 mai. 2009.

Gênero, raça, pobreza e emprego: o Programa GRPE no Brasil: Programa de Fortalecimento Institucional para a Igualdade de Gênero e Raça, Erradicação da Pobreza e Geração de Emprego. 2006b. Disponível em <http://www.oitamericas2006.org>. Acesso em: 06 jun. 2009.

Diálogo Social. Disponível em:

<http://www.ilo.org/public/spanish/dialogue/themes/sd.htm>. Acesso em: 21 de jul. 2010.

Trabalho decente. 2008. Disponível em: < http://www.oitbrasil.org.br/topic/decent_work/trab_decente_2.php >. Acesso em: 21 de jul. 2010.

ORGANIZAÇÃO MUNDIAL DE SAÚDE. El suicidio, un problema de salud pública enorme $y$ sin embargo prevenible, según la OMS. 2004. Disponível em: <http://www.who.int/mediacentre/news/releases/2004/pr61/es/>. Acesso em: 12 out. 2010.

PEREIRA, Caio Mário da Silva. Instituições de direito civil: teoria geral das obrigações. 23. ed. São Paulo: Gen-Forense, v. II, 2010.

PEREIRA, Luiz Carlos Bresser; GRAU, Nuria Cunill (Orgs). O Público Não-Estatal na Reforma do Estado. Rio de Janeiro: Editora FGV, 1999. 
POCHMANN, Márcio. Proteção Social na Periferia do Capitalismo: considerações sobre o Brasil. São Paulo em Perspectiva, São Paulo, v. 18, n. 2, p. 03-16, 2004.

RAMÍREZ, Magdalena Jiménez. Aproximacion teorica de la exclusion social: complejidad e imprecision del termino. Consecuencias para el ambito educativo. Estudios Pedagógicos, XXXIV, nº 1, p. 173-186, 2008.

RAMOS, Cristian. Trabalho decente. Disponível em: <http://white.oit.org.pe/proyectoactrav/pry_rla_06_m03_spa/actividades/documentos/brasi 1/jornadanac_agendasindical_anexo3.pdf>. Acesso em: 19 jul. 2010.

RODRIGUES JR., Otávio Luiz. Autonomia da vontade, autonomia privada e autodeterminação: Notas sobre a evolução de um conceito na Modernidade e na Pósmodernidade. Revista da Informação Legislativa. Brasília a. 41 n. 163 jul./set. 2004, p. 113-130.

RODRIGUEZ, Américo Plá. Princípios de Direito do Trabalho. 3. ed. São Paulo: LTr, 2000.

SANTOS, Ronaldo Lima dos. Teoria das Normas Coletivas. São Paulo: LTr, 2007.

SANTOS JR, Belisário dos. Direitos humanos priorizados pela justiça. 2001. Disponível em: <www.dhnet.org.br>. Acesso em: 23 jan. 2006.

SARLET, Ingo Wolfgang. A eficácia dos direitos fundamentais: uma teoria geral dos direitos fundamentais na perspectiva constitucional. 10. ed. Porto Alegre: Livraria do Advogado, 2009.

Os direitos Fundamentais Sociais na Constituição de 1988. 2001. Disponível em: <http://www.direitopublico.com.br/pdf/REVISTA-DIALOGO-JURIDICO-01-2001INGO-SARLET.pdf>. Acesso em: 19 jan. 2006.

SERPA, Luiz Felippe Perret. A contemporaneidade em Marx: conhecimento e trabalho. 200?. Disponível em: <http://www.faced.ufba.br/ nepec/noesis1/serpa.htm>. Acesso em: 10 set. 2010.

SILVA, Dercides Pires da. Trabalho análogo à escravidão: trabalho degradante. Disponível em: <http://sinpait.com.br/site/internas.asp?area=9901\&id=533>. Acesso em: 24 ago. 2010.

SILVA, José Afonso da. Curso de Direito Constitucional Positivo. 11. ed. São Paulo: Malheiros, 1996.

SILVA, Otávio Pinto e. Subordinação, autonomia e parassubordinação nas relações de trabalho. São Paulo: LTr, 2004.

SILVER, Hilary. Exclusión social y solidaridad social: tres paradigmas. Revista Internacional del Trabajo, vol.113, n.5-6, pp.607-662, 1994. 
SOARES, Jorgana Fernanda de Souza et al. O risco do uso de drogas no trabalho portuário: estudo no extremo sul do Brasil . Esc. Anna Nery, Dez 2007, vol.11, no.4, p.593-598. Disponível em: <http://www.scielo.br/pdf/ean/v11n4/v11n4a06.pdf>. Acesso em: 12 set. 2010.

SOMAVIA, Juan. Trabajo decente. Memorial da $87^{\mathrm{a}}$ Reunião da Conferência Internacional do Trabalho da OIT. 1999. Disponível em: <http://www.oit.org/public/spanish/standards/relm/ilc/ilc87/rep-i.htm>. Acesso em: 09 nov. 2007.

SOUTO MAIOR, Jorge Luiz. Proteção contra a dispensa arbitrária e aplicação da convenção 158 da OIT. Revista do Tribunal Regional do Trabalho da 15a Região, Campinas, n. 25, 2004. Disponível em: <http://trt15.gov.br/escola_da_magistratura/Rev25Art3.pdf>. Acesso em: 11 set. 2008.

STRECK, Lenio Luiz. Verdade e Consenso: constituição, hermenêutica e teorias discursivas; da possibilidade à necessidade de respostas corretas em direito. Rio de Janeiro: Lumen Juris, 2008.

SÜSSEKIND, Arnaldo et al. Instituições do Direito do Trabalho, 16. ed. São Paulo: LTr, 1996.

TOLEDO FILHO, Manoel Carlos; SOUTO MAIOR, Jorge Luiz. Da prisão civil por dívida trabalhista de natureza alimentar. 2003. Disponível em: <http://jus.uol.com.br/revista/texto/4337>. Acesso em 12 de dez.2010.

TRINDADE, José Damião da Lima. História dos Direitos Humanos. 2.ed., São Paulo: Peirópolis, 2002.

Direitos humanos: construção da liberdade e da igualdade. Centro de Estudos da Procuradoria Geral do Estado de São Paulo, 2000.

UNIVERSIDADE DE LISBOA. A vida em um Mosteiro Medieval. 2010. Disponível em: <http://www.educ.fc.ul.pt/docentes/opombo/hfe/momentos/modelos/vidamosteiro.htm>.

Acesso em 21 nov.2010.

VATICANO. Encíclica Rerum Novarum. 2010a. Disponível em: <http://www.vatican.va/holy_father/leo_xiii/encyclicals/documents/hf_lxiii_enc_15051891_rerum-novarum_po.html>. Acesso em 24 ago. 2010.

VATICANO. Encíclica Quadragesimo Anno. 2010b. Disponível em: < http://www.vatican.va/holy_father/pius_xi/encyclicals/documents/hf_pxi_enc_19310515_quadragesimo-anno_po.html>. Acesso em 24 ago. 2010.

VELLOSO, Gabriel; FAVA, Marcos Neves (org.). Trabalho escravo contemporâneo: o desafio de superar a negação. São Paulo: LTr-Anamatra, 2006.

VENOSA, Sílvio de Salvo. Curso de direito civil: responsabilidade civil. 5. ed. São Paulo: Atlas. v. IV, 2005. 
VIDAL NETO, Pedro. Estudo sobre a interpretação e aplicação do Direito do Trabalho. 1985, 226 p. (tese para concurso à livre docência de Direito do Trabalho, apresentada à Faculdade de Direito da Universidade de São Paulo)

VILLELA, José Corrêa. Conceito jurídico de pobreza na construção da Segurança Social. 2006. Tese (Doutorado em Direito) - Faculdade de Direito da Universidade de São Paulo, São Paulo.

WAMBIER, Teresa Arruda Alvim et al. Reforma do Judiciário: Primeiras Reflexões sobre a Emenda Constitucional n. 45/2004. São Paulo: Revista dos Tribunais, 2005.

WEFFORT, Francisco. Qual Democracia? São Paulo: Cia. das Letras, 1992.

WORLD BANK. Governance and development. Washington: Oxford University Press, 1992.

ZIONI, Fabíola. Exclusão Social: noção ou conceito? In Revista Saúde e Sociedade, v.15, n.3, p.15-29, set-dez 2006. 